\title{
DISCIPLINA JURÍDICA DO CÂMBIO E POLÍTICA PÚBLICA
}

Dissertação de Mestrado

Orientador:

Professor Doutor JOSÉ TADEU DE CHIARA

Faculdade de Direito da Universidade de São Paulo

Departamento de Direito Econômico e Financeiro

SÃO PAULO

2009 


\section{PARA TIAGo}




\section{AGRADECIMENTOS}

Agradeço ao Professor José Tadeu De Chiara pela generosidade, confiança e orientação precisa.

Aos Professores Haroldo Malheiros Duclerc Verçosa e Gilberto Bercovici, pelas valiosas contribuições no exame de qualificação.

A Renato Gomes de Souza, Flávia Martins Sant'Anna Perlingeiro e Luis Cláudio Gomes Pinto, por terem despertado, há tempos, meu interesse pelo assunto.

A Aloysio Meirelles de Miranda Filho e Adriana Baroni Santi Barstad, pelo apoio irrestrito.

A Marcos Sader, pela dedicação com que cuidou do que não podia esperar.

A Hélio Rubens de Oliveira Mendes, pela gentileza e cuidado com que reviu o texto.

A Tiago, pelo amor incondicional e paciência sem fim.

A avó, mãe e irmãos, por apoiarem minhas escolhas e compreenderem minhas ausências.

Ao pai, por sempre ter acreditado em mim. 


\section{ÍNDICE}

PáG.

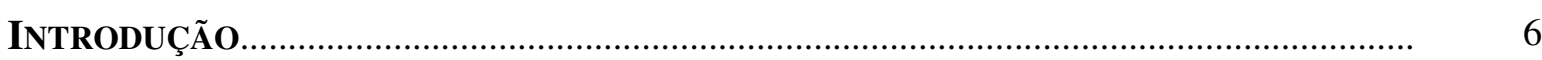

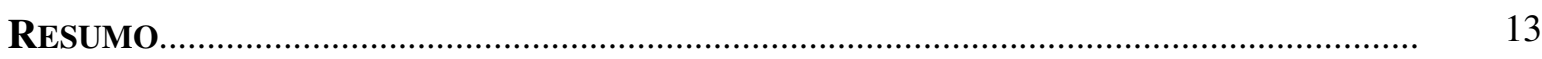

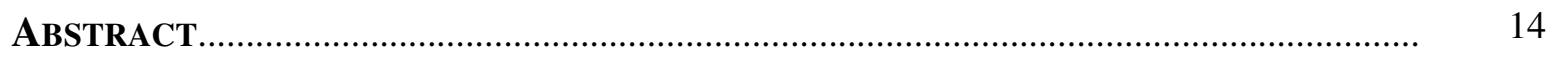

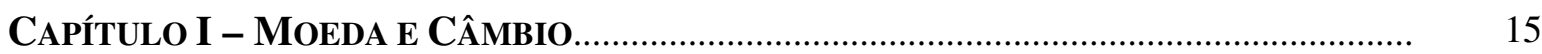

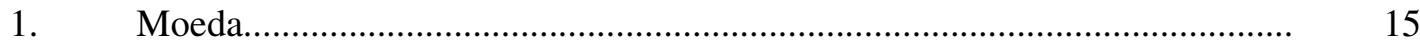

1.1. Considerações históricas................................................................ 15

1.2. Conceito de moeda........................................................................ 19

1.3. Funções da moeda.......................................................................... 21

1.4. Valor da moeda e poder de compra..................................................... 24

1.5. Curso legal e curso forçado da moeda nacional.................................... 29

2. Câmbio ........................................................................................................ 31

2.1 Moeda estrangeira................................................................. 31

2.2. Contrato de câmbio..................................................................... 32

2.3. Taxa de câmbio.......................................................................... 36

Capítulo II - Atuação do Estado no e sobre Processo Econômico............... 40

3. Constituição econômica e ordem econômica.................................................... 40

4. Política econômica....................................................................................... 49

5. As formas de atuação do Estado no e sobre o processo econômico.................. 52

6. Atuação do Estado no câmbio.......................................................................... 58

6.1. Regimes cambiais...................................................................... 65

6.2. Controles cambiais.................................................................... 73

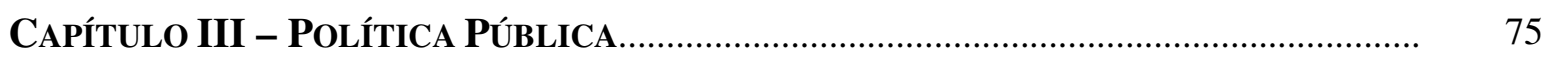

7. Política pública: caracterização.................................................................... $\quad 75$

8. Política pública e política econômica.................................................................... 80

9. Os fins da política pública na Constituição de 1988........................................ 82

9.1. A ordem econômica na Constituição de 1988: fundamentos, princípios e fins.

9.2. O desenvolvimento nacional como síntese......................................... 88 
10. Disciplina jurídica do câmbio: histórico; circunstâncias econômicas e políticas.

10.1. Até a década de 1930....................................................................... 99

10.2. Década de 1930............................................................................ 102

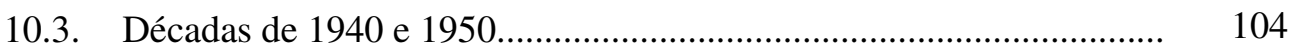

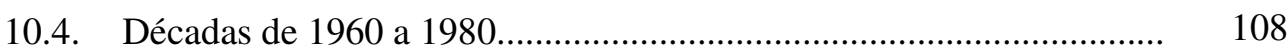

10.5. A partir da década de 1990.......................................................... 115

11. A desregulamentação cambial..................................................................... 118

12. Quadro normativo atual do câmbio....................................................................... 127

12.1. Operações de exportação...................................................................... 132

12.2. Registro de capitais estrangeiros........................................................ 140

12.3. Adiantamentos sobre contratos de câmbio......................................... 144

12.4. Infrações cambiais........................................................................ 152

12.4.1. Prática de operações ilegítimas de câmbio. Jogo sobre o

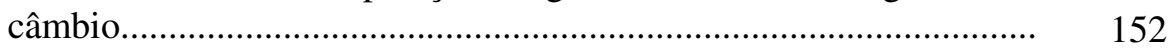

12.4.2. Compensação privada de créditos e valores....................... 155

12.4.3. Declarações falsas em contrato de câmbio. Classificação incorreta de contrato de câmbio.......................................................... 159

12.4.4. Crimes cambiais........................................................... 162

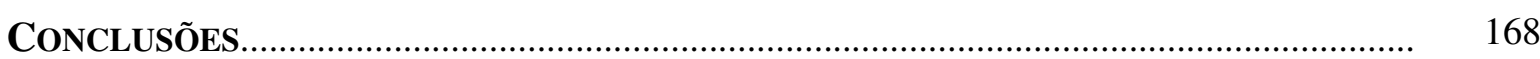

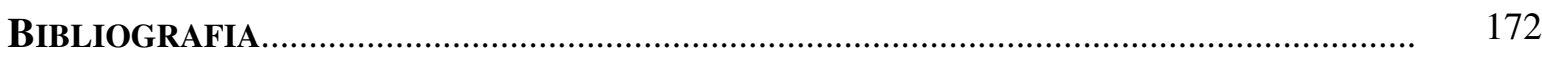

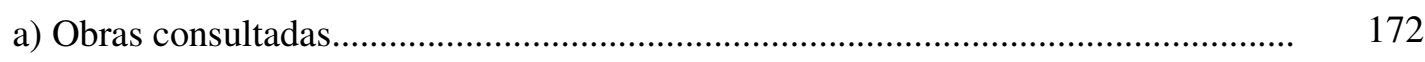

b) Obras consultadas de autores institucionais....................................................... 180 


\section{INTRODUÇÃO}

Tratamos, nesta dissertação, da disciplina jurídica do câmbio e sua relação com a política pública.

No primeiro capítulo, serão abordados aspectos introdutórios sobre a moeda e o câmbio, que entendemos serem relevantes para a compreensão do fenômeno cambial e da sua regulação. Mostraremos a importância da moeda nas sociedades capitalistas contemporâneas, a partir do desenvolvimento de um breve histórico sobre a formação das economias de mercado. Com o fim do feudalismo e a consolidação do capitalismo no mundo ocidental, a moeda, mais do que instrumento a facilitar as trocas e a permitir a especialização do trabalho, torna-se o padrão de riqueza e o denominador comum sobre o qual gira toda a vida econômica e a partir do qual "serão formuladas e poderão ser compreendidas as soluções de ordem, e as regras de direito voltadas para a tutela dos interesses patrimoniais"'.

A moeda é unidade ideal dotada das funções de instrumento de troca, meio de pagamento, reserva de valor e padrão de valor. Quando permite a divisão do trabalho e a circulação de riquezas, garante, por conseqüência, a contínua reprodução das bases do capitalismo. A produção efetiva dos efeitos da moeda, notadamente a possibilidade de pôr fim aos vínculos obrigacionais, é garantida dentro de uma ordem jurídica específica. A moeda é, pois, instituto jurídico.

Ainda no primeiro capítulo, faremos algumas observações sobre o valor da moeda e o seu poder de compra. O valor da moeda não é determinado pelo valor do material no qual é cunhada, tampouco por algum lastro ou pelo valor nominal que lhe é atribuído pelo Estado emissor, mas se identifica com a quantidade de bens ou serviços que possibilita adquirir, ou seja, com o seu poder de compra.

O poder de compra pode ser entendido como expressão de liberdade, pois confere ao titular da moeda a possibilidade de utilizá-la da forma que lhe pareça mais adequada (seja, por exemplo, adquirindo bens no mercado ou realizando investimentos).

\footnotetext{
${ }^{1}$ JoSÉ TADEU De CHIARA, Moeda e Ordem Jurídica, p. 14.
} 
Ao refletir a quantidade efetiva de bens ou serviços que podem ser adquiridos com a moeda, o poder de compra deve ser considerado em conjunto com os estudos sobre o valor da moeda, superando o nominalismo.

Cada indivíduo, ao decidir comprar bens ou contratar serviços e pagá-los com moeda, ou ao optar por poupar seus recursos, afeta, em maior ou menor grau, a economia como um todo. Os efeitos das relações intermediadas por moeda extrapolam a relação bilateral entre as partes do negócio jurídico e espalham-se por toda a sociedade, na medida em que a satisfação das necessidades se dá apenas com um ato posterior de troca, e não com a simples disponibilidade de moeda. Em verdade, a instrumentação da troca pela moeda induz a parte que a recebe a celebrar uma nova relação de troca, com o objetivo de satisfazer suas reais necessidades.

O Estado, no exercício da política econômica, administra a moeda, notadamente através do controle da quantidade de moeda em circulação na economia (seja através do exercício do poder emissor, das operações no mercado aberto, entre outras). Influencia, dessa forma, o poder de compra da moeda nacional e as decisões individuais dos titulares da moeda no direcionamento de seus recursos.

Fora da ordem jurídica sob a qual é emitida, a moeda perde suas funções típicas e torna-se mercadoria ou bem. Mercadoria, contudo, de caráter especial, pois, em razão das restrições impostas pelo curso legal, não pode ser trocada por qualquer outro bem. Para que o titular da moeda estrangeira possa, efetivamente, investir-se em situação de liquidez, deve, primeiramente, converter a moeda estrangeira em moeda nacional, através da celebração de um contrato de câmbio.

O contrato de câmbio caracteriza-se como contrato de compra e venda, no qual a moeda estrangeira é o bem objeto de negociação. O preço relativo a essa compra e venda é fixado em moeda nacional, tendo por base a taxa de câmbio praticada.

A relação de troca entre a moeda nacional e a moeda estrangeira expressada na taxa de câmbio não pode ser explicada apenas pela paridade real entre os poderes de compra de cada uma das moedas em seus mercados domésticos, tampouco reflete a noção de equivalência típica do preço na compra e venda. Em verdade, está sujeita à influência de diversos outros fatores, tais como a relação internacional de troca e atos de política econômica dos seus respectivos países emissores. 
A administração da taxa de câmbio também é ato de política econômica do Estado da maior relevância. No plano das relações internacionais, o Estado age de forma a preservar a estabilidade da moeda nacional e garantir o seu poder de compra, com o fim de assegurar a disponibilidade de divisas necessárias para fazer frente às obrigações externas assumidas pelo próprio Estado ou pelos seus nacionais. Para tanto, o Estado atua através da imposição de controles cambiais ou comparece ao mercado celebrando operações que possam afetar o preço da moeda estrangeira (como a compra ou venda de moeda estrangeira ou de títulos indexados à variação cambial, ou a celebração de operações no mercado de derivativos), com conseqüências diretas na economia e na condução das políticas públicas.

No segundo capítulo, trataremos da atuação do Estado no e sobre o processo econômico. Será mostrado como, a partir do início do século XX, as assimetrias do capitalismo ficaram mais expostas e o papel do Estado na economia foi sendo ampliado para abarcar não só aqueles atos necessários à garantia da preservação do sistema vigente, mas também a adoção de políticas de médio a longo prazo, de forma planejada e com o objetivo de tornar reais os objetivos eleitos pela sociedade como prioritários no bojo, principalmente, das Constituições Econômicas.

Como ensina FÁBIo Konder COMPARATO, as intervenções do Estado liberal limitavam-se à conjuntura, mas a política econômica do Estado contemporâneo é global e sistemática, e tem por objetivo a expansão, procurando atingir as próprias estruturas do sistema econômico no sentido do seu aperfeiçoamento ou de sua transformação ${ }^{2}$.

Mais especificamente, mostraremos que a política econômica, em verdade, identifica-se com própria a atuação do Estado no e sobre o processo econômico, a qual deve ser direcionada para a consecução dos fins determinados pela sociedade.

Discorreremos, nesse passo, sobre as formas de atuação do Estado no e sobre o processo econômico, dando ênfase ao exercício da capacidade normativa de conjuntura, a qual se refere a atos do Estado destinados a regular situações não estruturais que, pela sua natureza, demandam atuação rápida e direcionada por parte do Estado. É através de atos emanados no exercício da capacidade normativa de conjuntura que o

\footnotetext{
${ }^{2}$ O Indispensável Direito Econômico, p. 21.
} 
Conselho Monetário Nacional (CMN) disciplina e o Banco Central do Brasil (BACEN) implementa a política cambial do País.

No que se refere especificamente à atuação do Estado quanto ao câmbio, iniciaremos a análise tratando, ainda que de forma resumida e pontual, dos mecanismos que o Estado utiliza para atuar nessa área.

Ao atuar do mercado de câmbio, o Estado influencia na formação da taxa de câmbio. Pelo menos teoricamente, procura fazer com que seja atingida a taxa de câmbio de equilíbrio ou "justa", entendida como aquela capaz de proporcionar o maior bem-estar para a sociedade como um todo em um determinado momento histórico.

O nível de intervenção do Estado na formação da taxa de câmbio está relacionado com o regime de câmbio adotado. Entre o regime de taxas fixas, no qual as taxas são previamente determinadas, e o regime de taxas puramente flutuantes, diversas variações podem ser constatadas e que identificam maior ou menor grau de atuação do Estado no sentido de influenciar em sua formação.

Nas últimas décadas, ganhou importância a defesa de um regime de livre flutuação da taxa de câmbio que, em consonância com a ideologia neoliberal, defende a omissão da intervenção ou o mínimo de intervenção estatal na formação das taxas de câmbio. A Constituição Federal, ao determinar finalidades para atuação do Estado, não admite a omissão do Estado como política institucionalizada; ao contrário, determina a direção da sua atuação no sentido de cumprir os objetivos de bem-estar geral nela previstos. Por certo, os atos do Poder Público, nessa matéria, têm caráter instrumental e estão submetidos a juízo de sua compatibilidade com a ordem jurídica vigente.

Ainda no segundo capítulo, traremos algumas considerações gerais sobre os controles cambiais, os quais se identificam com as medidas restritivas adotadas pelo Estado no que se refere ao câmbio e que têm por objetivo, prioritariamente, resguardar as reservas cambiais do país. Os controles cambiais adotados no Brasil serão discutidos com mais aprofundamento, em uma perspectiva histórica, no quarto capítulo.

No terceiro capítulo desta dissertação, discorreremos sobre as políticas públicas. 
Após a revelação das assimetrias do capitalismo, notadamente no início do século XX, ficou constatado que o ideal de liberdade plena propugnado pelo liberalismo comprometeria a própria sobrevivência do sistema. Mesmo contra os interesses individuais dos burgueses, o Estado deveria agir ativamente, de forma a garantir as bases necessárias para a continuidade do sistema como um todo.

Toda a atuação do Estado deve respeitar e estar pautada nas normas constitucionais e deve visar a implementação dos objetivos e metas fixados no ordenamento jurídico, expressos nas políticas públicas. A política econômica do Estado incluindo a política cambial - não constitui um objetivo em si mesmo, mas é instrumento a viabilizar que, na prática, seja atingida a situação econômica necessária para a concretização dos objetivos e metas sociais eleitos pela sociedade.

As políticas públicas, dessa forma, podem ser entendidas como programas de ação governamental, direcionadas à perseguição de fins específicos determinados no sistema jurídico, os quais visam, em última análise, a promoção do bem-estar da coletividade.

As políticas públicas possuem potencial efetivamente transformador, na medida em que trazem uma possibilidade de concretude aos fins almejados e eleitos como prioritários pela sociedade. Não há como afirmar, todavia, que as políticas públicas teriam caráter revolucionário, já que visam, primordialmente, as mudanças necessárias para a preservação e reprodução do sistema, assim como toda e qualquer atuação do Estado respaldada no ordenamento jurídico.

Para perseguição dos fins das políticas públicas na ordem jurídica, os fundamentos, princípios e fins da ordem econômica, contemplados na Constituição Federal de 1988, devem ser analisados. Dessa análise, depreende-se que o desenvolvimento nacional surge como uma síntese das políticas públicas, ao englobar uma transformação social ampla, de dentro para fora e duradoura, que faz com que o nível de desenvolvimento social atinja um novo patamar. Cada um dos fins previstos na Carta Magna, como a diminuição das desigualdades regionais, a promoção da saúde pública, a melhoria da educação, a preservação do meio ambiente, justificam, sem dúvida, a adoção de políticas públicas setoriais e específicas, mas todos eles estão presentes na noção trazida pelo desenvolvimento nacional. 
O desenvolvimento nacional, ao contrário de ser um momento histórico final que, depois de atingido, teria a capacidade de se auto-sustentar, é um processo contínuo, que demanda, a cada novo patamar alcançado, a perseguição de novos desafios, almejando sempre um maior nível de padrão de vida para a população como um todo.

A atuação do Estado no domínio econômico, e no câmbio em especial, está vinculada, por conseguinte, aos fins determinados no ordenamento. É preciso que a atuação do Estado na área cambial seja devidamente justificada como necessária ou adequada à concretização das políticas públicas determinadas na Carta Magna e que são sintetizadas na noção de desenvolvimento nacional.

No quarto e último capítulo deste trabalho, serão discutidas as relações entre a disciplina jurídica do câmbio no Brasil e a política pública.

Iniciaremos a análise com histórico sobre a disciplina jurídica do câmbio no Brasil. Tenta-se mostrar a realidade política e econômica no País no momento de edição dos principais textos normativos que tratam do câmbio, com o objetivo de proporcionar melhor compreensão sobre os mesmos.

Ao final da década de 1980, iniciou-se um processo chamado de “flexibilização das normas cambiais" ou "simplificação das normas cambiais", que, sob o argumento de que visava empreender uma necessária modernização do regime jurídico do câmbio no País, vem, em linha com uma doutrina neoliberal que prega o afastamento do Estado da vida econômica, apregoada no Consenso de Washington, promovendo a diminuição progressiva dos controles cambiais no País. Os controles cambiais haviam sido instituídos a partir da década de 1930, em resposta às dificuldades enfrentadas em razão da Crise de 1929, e permaneceram, em sua essência, em vigor durante a maior parte do século XX.

Os desdobramentos desse processo de "flexibilização" podem ser constatados na criação do mercado de taxas flutuantes e na sua posterior unificação ao mercado de câmbio de taxas livres, na revogação da obrigatoriedade de cobertura cambial nas operações de exportação e na diminuição dos requisitos para concessão do registro do capital estrangeiro. Sua implementação tem sido feita, na maior parte, através da mudança de interpretação dos textos normativos pela autoridade monetária e pela edição de regras infralegais. 
Por fim, em uma tentativa de síntese, tratemos um quadro normativo atual da matéria cambial e, com o intuito de reforçar sua relação com a política pública, discorreremos sobre alguns casos específicos que refletem, de forma prática, essa relação.

Em primeiro lugar, trataremos das operações de exportação, para mostrar que a cobertura cambial obrigatória das receitas auferidas nas exportações, um dos pilares do regime instituído na década de 1930 e que tinha por objetivo garantir o fluxo contínuo de divisas para o País, foi revogado em 2006.

No que se refere aos registros de capitais estrangeiros, os quais são condição necessária a permitir o retorno do capital estrangeiro e dos rendimentos ou ganhos de capital ao exterior, podemos constatar uma mudança na interpretação do BACEN quanto aos critérios para a sua concessão. Paulatinamente, o BACEN veio admitindo o registro em situações que antes não admitia, por entender não estar configurado o requisito de necessária aplicação do capital estrangeiro em atividade econômica no País. Mais adiante, a legislação foi alterada para prever o registro em moeda nacional de investimentos não sujeitos a registro com base na legislação precedente. Dessa forma, o requisito de aplicação em atividade econômica, que buscava direcionar os investimentos para atividade capaz de incrementar a capacidade produtiva do País, foi esvaziado.

Mostraremos, em seguida, que a disciplina dos adiantamentos sobre contratos de câmbio (ACC) demonstra uma série de medidas adotadas pelo Estado com o intuito de incentivar a realização dessas operações pelos exportadores, sob o argumento de que promovem um maior financiamento da atividade exportadora. Os incentivos, contudo, são todos concentrados no esforço para ingresso dos recursos, sem que haja a garantia de sua aplicação imediata na atividade produtiva. Em realidade, diante das diferenças das taxas praticadas no mercado internacional e no mercado doméstico, o maior incentivo é para aplicação desses recursos no mercado financeiro.

Por fim, trataremos, brevemente, das infrações cambiais administrativas e dos crimes cambiais, os quais têm por objetivo reprimir condutas que, em última instância, possam criar dificuldades à boa condução da política cambial pelo Estado, notadamente ao controle das operações cambiais pelo BACEN e à proteção das divisas do País. 


\section{RESUMO}

A presente dissertação tem por objetivo discorrer sobre a disciplina jurídica do câmbio no direito brasileiro e a sua relação com a política pública.

A taxa de câmbio, ao expressar a relação de troca entre a moeda nacional e a moeda estrangeira, está sujeita à influência de diversos fatores que extrapolam os poderes de compra das respectivas moedas e que não refletem a noção de equivalência presente na determinação do preço nas compras e vendas, como a relação internacional de troca e atos de política econômica dos Estados envolvidos.

O Estado, ao exercer a política cambial, dever agir conforme os princípios e fundamentos previstos na Constituição Federal. Sua atuação deve ser direcionada à implementação dos objetivos eleitos pela sociedade como prioritários, os quais estão fixados na Carta Magna. Esses objetivos encontram possibilidade de concretude nas políticas públicas.

PALAVRAS-CHAVE: MOEDA. CÂMBIO. REGIME JURÍDICO. POLÍTICA PÚBLICA. POLÍTICA ECONÔMICA. 


\begin{abstract}
This paper aims at discussing the legal framework of foreign exchange transactions in the Brazilian legal system and its relation with public policy.

The exchange rate expresses the relation between the exchange of local currency and foreign currency. The rate is subject to the influence of several different factors other than the purchasing power of the relevant currencies (i.e. the terms of foreign international relations and economic policy acts of the respective countries), and does not reflect the notion of equivalence that is present in the determination of price in buy and sell transactions.
\end{abstract}

When exercising the exchange rate policy, the Brazilian government shall act in accordance with the principles and fundamental rules provided for in the Federal Constitution, and shall endeavor the realization of the objectives determined as priority therein. Public policies are an important tool in the realization of those objectives.

KEY WORDS: MONEY. FOREIGN EXCHANGE. LEGAL DISCIPLINE. PUBLIC POLICY. ECONOMIC POLICY. 


\title{
MOEDA E CÂMBIO
}

\author{
SumÁRIO: 1. Moeda. - 1.1. Considerações históricas. - 1.2. Conceito de \\ moeda. - 1.3. Funções da moeda. - 1.4. Valor da moeda e poder de \\ compra. - 1.5. Curso legal e curso forçado da moeda nacional. - 2 . \\ Câmbio. - 2.1. Moeda estrangeira. - 2.2. Contrato de câmbio. - 2.3. Taxa \\ de câmbio.
}

\section{MOEDA.}

\subsection{CONSIDERAÇÕES HISTÓRICAS.}

$\mathrm{Na}$ sociedade feudal, entre os séculos $\mathrm{X}$ a XII, a riqueza das classes dominantes - formadas pela nobreza feudal e pelo clero - era medida pela propriedade da terra $^{3}$. Em troca de proteção militar ou de ajuda espiritual, o servo entregava a sua força de trabalho, através do cultivo das terras e da prestação de serviços ao seu senhor.

Em cada feudo, formava-se um núcleo de poder relativamente independente, com vida praticamente autônoma ${ }^{4}$. A ligação entre os diversos feudos era precária e o comércio existia de forma ainda incipiente. A produção se destinava quase que totalmente à subsistência e o pouco excedente era utilizado para a troca direta de produtos,

\footnotetext{
${ }^{3}$ Leo Huberman, História da Riqueza do Homem, p. 10. Mais adiante, o autor resume as relações de poder na sociedade feudal da seguinte forma: "o clero e a nobreza constituíam as classes governantes. Controlavam a terra e o poder que delas provinha. A Igreja prestava ajuda espiritual, enquanto a nobreza, proteção militar. Em troca, exigiam pagamento das classes trabalhadoras, sob a forma de cultivo das terras" (p. 15).

${ }^{4} \mathrm{Na}$ organização da sociedade feudal, o senhor não era necessariamente o proprietário último das terras. Na base da sociedade, situavam-se os servos. Acima deles, havia os senhores feudais, que arrendavam a terra, eles próprios, de outros senhores feudais, alguns deles com títulos de nobreza. Assim, arrendava-se as terras de um conde, que as arrendara de um duque e que as arrendara do rei (LEO HUBERMAN, ob. cit., p. 9). A estrutura de poder dividida em escalas não comprometia a relativa independência de cada feudo, que normalmente tinha um sistema jurídico próprio baseado no costume nele desenvolvido.
} 
a maior parte deles produzidos dentro do próprio feudo. O dinheiro era pouco utilizado e, em regra, cada feudo tinha sua própria moeda.

Impulsionado pelas Cruzadas, o comércio passa a ganhar importância e impõe a mudança da antiga economia natural. Surgem as feiras periódicas, entre os séculos XII a XIV, com o intuito de promover um comércio mais estável para os produtos trazidos de regiões distantes.

Além do comércio de mercadorias, parte importante das feiras era dedicada à realização de operações financeiras e os dias finais das feiras eram dedicados a negócios em dinheiro. Com a sofisticação do comércio, a troca direta de mercadorias passa a não mais satisfazer plenamente as necessidades das pessoas. A utilização do dinheiro como intermediário de troca ganha importância, mas a existência de diversas moedas distintas e de qualidade diversa exigia o serviço dos negociadores de dinheiro, que pesavam, avaliavam e trocavam muitas variedades de moedas. Além disso, negociavam-se empréstimos, pagavam-se dívidas antigas e a circulavam-se letras de crédito e letras de câmbio.

\begin{abstract}
"Assim, o uso do dinheiro torna o intercâmbio de mercadorias mais fácil e, dessa forma, incentiva o comércio. A intensificação do comércio, em troca, reage na extensão das transações financeiras. Depois do século XII, a economia de ausência de mercados se modificou para uma economia de muitos mercados; e com o crescimento do comércio, a economia natural do feudo auto-suficiente do início da Idade Média se transformou em economia de dinheiro, num mundo de comércio em expansão"5.
\end{abstract}

A partir da intensificação do comércio, surgem as cidades e nelas forma-se uma nova classe de mercadores, que, ansiosos por liberdade para desenvolver suas atividades, organizaram-se em corporações e romperam paulatinamente com as restrições impostas pelo sistema feudal (incluindo a alta carga de tributos). A ascensão da classe média se desenvolve no decorrer do século XV e o dinheiro vai, pouco a pouco, tornandose a nova medida de riqueza do homem ${ }^{6}$.

\footnotetext{
${ }^{5}$ LeO HuBERMAN, ob. cit., p. 24.

6 "Nos primórdios do feudalismo, a terra, por si só, constituía a medida da riqueza do homem. Com a expansão do comércio surgiu um novo tipo de riqueza - a riqueza em dinheiro. No início da era feudal o dinheiro era inativo, fixo, móvel; agora tornara-se ativo, vivo, fluido. No início da era feudal os sacerdotes e
} 
A desordem e a insegurança, típicas de uma sociedade fracionada como a feudal, prejudicavam a expansão dos negócios e a burguesia ascendente viu no fortalecimento do poder do rei a oportunidade de lutar contra os senhores feudais e de ter segurança e previsibilidade garantidas por um poder central. A transferência do poder dos núcleos regionais para um monarca vem ao encontro dos interesses da burguesia ascendente, garantindo a uniformidade necessária para a maior circulação das riquezas.

Como contrapartida, os burgueses financiaram a formação dos Estados Nacionais e as aspirações expansionistas dos monarcas. Entre os séculos XVII e XVIII, entendia-se que a riqueza de um país estava relacionada com a quantidade de ouro e prata que conseguia acumular em suas reservas e o suprimento de metais dos países europeus era garantido pela América, seja pela exploração direta pelas metrópoles seja pela prática de uma balança comercial favorável (esse último mecanismo foi utilizado em ampla escala pela Inglaterra).

Mas a organização absolutista, marcada pelo mercantilismo, impunha uma série de restrições e regulamentações ao desenvolvimento das atividades mercantis, o que desagradava sobremaneira a classe burguesa, ansiosa por liberdade para expandir seus negócios. O monarca absoluto, antes aliado na luta contra a velha ordem feudal, passa a ser visto como um entrave ao desenvolvimento do comércio. A burguesia, já titular do poder econômico, ansiava pelo poder político correspondente, e, com esse objetivo, liderou as classes populares para a tomada do poder, conquistado de forma emblemática na França com a Revolução Francesa, em 1789. Após esse período, e com a consolidação do sistema trazido pela Revolução Industrial, os mercados, antes acessórios da vida econômica, passam a ocupar papel central ${ }^{7}$.

O Estado Moderno trouxe um processo de institucionalização dos monopólios da violência e da tributação e a separação do patrimônio do chefe do Estado do patrimônio do próprio Estado. Na sociedade feudal, os poderes político e econômico são

guerreiros, proprietários de terras, situavam-se num dos extremos da escala social, vivendo do trabalho dos servos, que se encontravam no outro extremo. Agora, um novo grupo surgia - a classe média, vivendo de uma forma diferente, da compra e da venda. No período feudal, a posse da terra, a única fonte de riqueza, implicava o poder de governar para o clero e a nobreza. Agora, a posse do dinheiro, uma nova fonte de riqueza, trouxera consigo a partilha no governo, para a nascente classe média" (LEO HUBERMAN, ob. cit., p. $33)$.

${ }^{7}$ Karl POlAnYI, A Grande Transformação. A Origem de nossa Época, pp. 77 e 89. 
identificados no senhor feudal. No Estado Absolutista, a concentração dos dois poderes no monarca ainda se faz presente, o que é garantido pela sucessão hereditária ${ }^{8}$.

A transformação do monopólio pessoal em monopólio público, institucional, a partir da consolidação do Estado Moderno, ocorreu do ponto de vista formal. Na prática, não há dúvida de que o Estado era controlado pela burguesia, classe dominante no novo cenário, e que servia aos interesses de manutenção e reprodução do regime capitalista. De fato, a própria existência do Estado como entidade "neutra", aparentemente distinta da sociedade e que defende supostos interesses gerais, é condição necessária e indispensável, do ponto de vista prático e ideológico, para garantia da reprodução e manutenção do sistema ${ }^{9}$.

Apesar do que defendiam os pensadores liberais, desde o seu nascimento o Estado tem vocação para atuar na economia. O mercado ${ }^{10}$, ao contrário de ter se desenvolvido naturalmente na sociedade humana, é produto histórico e a sua existência apenas é possível em virtude da garantia de certas premissas básicas pela ordem jurídica e, em última instância, pelo Estado.

Nas sociedades capitalistas, a disponibilidade de moeda torna-se o novo padrão de riqueza, em substituição à propriedade fundiária no feudalismo. A circulação das riquezas e a divisão do trabalho são dois aspectos fundamentais para a manutenção e a reprodução do sistema, e a moeda é instrumento essencial para sua ocorrência. A compreensão desse fenômeno é fundamental para qualquer estudo que tenha por objeto a sociedade ocidental contemporânea.

\footnotetext{
${ }^{8}$ Norberto Bobbio, Teoria Geral da Política: a filosofia política e as lições dos clássicos, pp. 225-226.

${ }^{9}$ AlaÔR CAFF́ Alves, Estado e Ideologia. Aparência e Realidade, pp. 275-276.

${ }^{10} \mathrm{O}$ liberalismo econômico, até a virada do século XIX para o século XX, propugnava que ao Estado cabia primordialmente a função da produção do direito e segurança. Não se admitia sua interferência em uma suposta ordem natural da economia, que se encarregaria de quaisquer acertos necessários ao desenvolvimento. O ideal de igualdade traduziu-se, na prática, em uma igualdade apenas formal, que, por um lado, quebrou o regime estamental e garantiu ao burguês a possibilidade de participar ativamente no mercado, e, por outro, acentuou as desigualdades econômicas ao impor o mesmo tratamento a partes claramente desiguais. Diante das sucessivas crises do sistema capitalista, dentre as quais se destaca a Crise de 1929, o Estado teve que tomar para si a responsabilidade de implementar medidas que visassem diminuir as falhas do sistema a fim de garantir sua manutenção, bem como se viu obrigado a adotar políticas públicas para buscar atingir os objetivos eleitos pela sociedade como primordiais. Como bem observa EROS ROBERTO GRAU, o mercado é uma instituição jurídica (e não espontânea ou natural), cujo nascimento ocorre em um determinado período histórico graças a reformas institucionais operadas pelo direito. É uma ordem, no sentido de que a regularidade e a previsibilidade de comportamentos garantidas pelas regras jurídicas lhe servem de fundamento (A Ordem Econômica na Constituição de 1988 (interpretação e crítica), pp. 29-32).
} 


\subsection{CONCEITO DE MoEDA.}

Como observa JosÉ TADEU DE CHIARA, o conceito de moeda normalmente é apresentado a partir dos atributos e características que lhe são próprios ${ }^{11}$, especialmente a partir da identificação de suas funções básicas como intermediária de trocas, meio de pagamento, padrão de valor e reserva de valor, as quais serão exploradas adiante ${ }^{12}$.

TULLIO ASCARELLI aponta que usualmente trata-se, sob a expressão moeda, de dois fenômenos distintos. Primeiramente, refere-se à moeda como sendo uma unidade de medida destinada a comparar bens e serviços diversos. A moeda é, assim, um critério de medida de valor, e não uma coisa, passível de ser objeto de direito real ou de prestação. Em uma segunda acepção, a moeda é tratada como um instrumento de troca (e, assim, é uma peça monetária), que permite que, ao ser recebida por uma pessoa, possa ser utilizada posteriormente por essa pessoa em novas relações de compra e venda ou prestação de serviços ${ }^{13}$.

Para NuSSBAUM, a essência da moeda está identificada com a idéia de uma unidade ideal. Define a moeda como aquilo que, no comércio, entrega-se e recebe-se não pelo que fisicamente representa, mas somente como fração, equivalente ao múltiplo ("x" vezes) de uma unidade ideal ${ }^{14}$.

Para a caracterização da moeda, é essencial que a unidade ideal a ser considerada como moeda seja definida como tal pela ordem jurídica. Na explicação de DE CHIARA, "em termos conceituais, na ordem jurídica a moeda se constitui em expressão da linguagem que encontra sentido unicamente quando utilizada sob certas regras de direito e em certo sistema de direito positivo" ${ }^{\prime 15}$.

\footnotetext{
${ }^{11}$ Ob. cit., p. 46.

${ }^{12}$ RoBerto QuiRoga Mosquera destaca, como características fundamentais da moeda, (i) o fato de ser bem fungível, o que lhe garante a possibilidade de ser usada como instrumento de troca nas relações sociais; (ii) que o Direito determina o que é moeda; "moeda é norma, é estrutura de linguagem, linguagem prescritiva"; (iii) que a moeda deve ser aceita pela sociedade como tal, deve "ter o acolhimento institucional do grupo social respectivo"; (iv) o fato de que a moeda sempre representará uma unidade ideal; e (v) o fato de ser o instrumento utilizado pela sociedade para pôr fim às relações jurídicas de cunho pecuniário (Direito Monetário e Tributação da Moeda, pp. 58-59).

${ }^{13}$ Obbligazioni Pecuniarie, pp. 12-13.

${ }^{14}$ Teoria Jurídica del Dinero, pp. 29-33.

${ }^{15}$ Ob. cit., p. 57.
} 
José LuIZ Bulhões PeDREIRA reconhece que, nas economias modernas, a moeda é criada pelo Estado, na medida em que este "declara o que é moeda e impõe seu curso legal", mas enfatiza que "é indispensável que a moeda definida pelo Estado seja efetivamente aceita pela comunidade" ". No mesmo sentido, EUGÊNIO GUDIN defende que "a alma da moeda, a sua capacidade de exercer a função de meio de troca e de pagamento, residem em sua aceitação geral"17.

TiAgo MACHAdO CORTEZ reconhece que a moeda contemporânea é construída juridicamente, o que, no seu entender, não significa que a sua existência se deva ao direito. Vê a moeda como uma instituição social ou "resultado da ação dos indivíduos que estabelecem relações econômicas baseadas na troca". Parte da premissa de que não existe uma definição universal e atemporal de moeda e afirma que a moeda será aquilo que a sociedade exigir que ela seja ${ }^{18}$.

Parece-nos correta a percepção do autor de que todo fenômeno social deve ser analisado dentro do seu devido contexto histórico, levando-se em consideração as peculiaridades da sociedade no qual se manifesta ${ }^{19}$. A nosso entender, todavia, o autor peca ao englobar, dentro do mesmo conceito de moeda, fenômenos diversos. O papel dos objetos comestíveis, gado, escravos e mulheres como instrumentos a viabilizar trocas no povo Tiv ou as moedas utilizadas em Cartago para satisfação das despesas militares dificilmente podem servir de exemplos a demonstrar a inadequação do conceito de moeda apresentado. Podem, no máximo, auxiliar na compreensão da evolução histórica das relações econômicas nas sociedades.

Como já explorado, ainda que de forma rápida para não desviar do principal objeto de análise deste trabalho, interessa-nos a moeda nas sociedades contemporâneas, a qual é fundamentalmente instrumento de troca direta e medida de riqueza que torna possível dois dos pilares fundamentais do capitalismo, quais sejam a circulação de riquezas

\footnotetext{
${ }^{16}$ Finanças e demonstrações financeiras da companhia: conceitos e fundamentos, p. 33. O autor observa que a aceitação da moeda imposta pelo Estado traduz confiança no poder de compra da moeda e que, na ausência dessa confiança, a comunidade procura substituir a moeda por moeda estrangeira, metais ou mercadorias. Foi isso o que ocorreu na Alemanha do pós-guerra, quando cigarros norte-americanos passaram a ser usados como instrumento de troca ante o total descrédito da moeda decorrente de um processo de hiperinflação.

${ }^{17}$ Princípios de Economia Monetária, p. 26. ARTHUR NuSSBAUM destaca que a prática do comércio jurídico é que concede, a alguma coisa, a "alma de dinheiro", constituindo o processo psicológico constitutivo do conceito de moeda e, portanto, conclui o autor que o elemento confiança adquire, de um modo indireto, importância para a teoria jurídica (ob. cit., p. 45).

${ }^{18}$ Moeda, Estado e Direito: O Papel do Estado na Ordem Monetária e seu Controle, pp. 9-13.

${ }^{19}$ Nesse sentido, ASCARELLI afirma que a moeda é, obviamente, um fenômeno de grupo (ob. cit., p. 11).
} 
e especialização do trabalho. Traduz, portanto, liberdade na satisfação das necessidades pelo homem ${ }^{20}$.

Nesse sentido, a nosso ver, o reconhecimento, pela ordem jurídica, é fundamental para caracterização da moeda. É a ordem jurídica que estabelece o padrão monetário, atribuindo à moeda seu caráter de efetividade, ao determinar que seja aceita como meio de pagamento nas relações internas do país, promovendo a liberação dos vínculos obrigacionais.

Reconhecemos, como alertado por BULHÕES PEDREIRA, GUDIN e NuSSBAUM, a importância da confiança, pela sociedade, na sua moeda para que ela possa exercer plenamente todas as funções. Acreditamos, todavia, que a perda de confiança pode indicar aos administradores públicos a necessidade de alterações na sua política econômica ou, em caso extremo, a imperiosidade de substituição da moeda. Não é suficiente, contudo, para descaracterizá-la a ponto de se considerar que ela deixa de ser moeda.

\subsection{FUNÇÕES DA MOEDA.}

A troca de mercadorias direta, sem o uso da moeda ou com o uso eventual de moeda, foi usada de forma predominante em um estágio mais primitivo das formações sociais até o período feudal.

No decorrer dos séculos, na medida em que o sistema capitalista foi se formando e se consolidando, a troca direta foi sendo substituída pela troca indireta, intermediada por moeda, já que aquela implica enormes dificuldades, muitas vezes instransponíveis, para a livre circulação de bens e serviços e para a especialização do trabalho.

A dificuldade mais imediata é a necessidade de uma dupla coincidência ou um encontro perfeito de vontades: cada indivíduo deve encontrar um outro que tenha

\footnotetext{
${ }^{20}$ JosÉ TADEU DE CHIARA, ob. cit., p. 47.
} 
exatamente o bem de que precise e que, ao mesmo tempo, esteja disposto a trocá-lo pelo bem que tem para oferecer. ${ }^{21}$

Além disso, em uma economia baseada na troca direta, a tendência das pessoas é produzir bens diversificados, a fim de aumentar a chance de trocas futuras, o que compromete a especialização do trabalho e o aumento de produtividade que dela decorre. Como nota MANKIw, "ao fluir de pessoa para pessoa na economia, o dinheiro facilita a produção e o comércio, permitindo que cada pessoa se especialize naquilo que sabe fazer melhor e elevando o padrão de vida de todos"22.

Uma outra dificuldade inerente às trocas diretas é a determinação da real equivalência de valor entre bens e serviços de distintas naturezas. A moeda serve como referência para comparação de bens e serviços que, sem essa simplificação, são dificilmente comparáveis.

$\mathrm{Na}$ troca indireta, instrumentada por moeda, apenas uma das partes satisfaz imediatamente as suas necessidades. A outra recebe, em contrapartida, a moeda, que deverá ser utilizada posteriormente para a satisfação das suas necessidades em outro ato de troca instrumentado por moeda. Pressupõe, portanto, a existência de duas operações de compra e venda, diretas e complementares. "A primeira e a segunda operação apenas se efetivam porque há confiança das respectivas partes negociantes que o elemento intermediário (a moeda) cumprirá seu papel, tornando viável sua utilização como meio geral de troca nas operações que se sucederão no mercado" ${ }^{23}$. Diante desse quadro, fica evidente, pois, o caráter de meio (e não de fim) da moeda ${ }^{24}$.

A moeda veio, assim, na sua função de intermediária de troca, conferir maior eficiência e facilidade às trocas, permitir maior especialização do trabalho e contribuir para uma melhor alocação dos fatores de produção. A partir do reconhecimento da importância da livre circulação de riquezas para a manutenção e expansão do sistema capitalista, fica evidente a sua relevância nos Estados contemporâneos.

\footnotetext{
21 Nas palavras de MANKIw, a economia de escambo pressupõe a "dupla coincidência de desejos - a improvável circunstância em que duas pessoas tenham, cada uma, os bens ou serviços que a outra deseja" (Introdução à Economia, p. 628).

${ }^{22}$ Ob. cit., p. 628.

${ }^{23}$ RoBerto QuiROGA MOSQUERA, ob. cit., p. 64.

${ }^{24}$ José TADEU DE CHIARA, ob. cit., pp. 23-25.
} 
Se a troca indireta pode ser dissociada em duas operações de compra e venda, em cada uma dessas operações surge uma dívida, que necessita de um pagamento, o que é feito por meio da moeda, que exerce, então, a função de meio de pagamento ${ }^{25}$. De fato, como será abordado a seguir, em virtude do curso legal e do curso forçado, o pagamento em moeda nacional põe fim às relações obrigacionais de forma imperativa, sem que seja facultada ao devedor a recusa do seu recebimento.

A moeda exerce, ainda, como já destacado, a função de padrão de valor ou unidade de conta, na medida em que funciona como denominador comum ou referência a possibilitar a comparação bens e serviços de diferente natureza e diminuindo a sua complexidade.

Em um sistema de troca direta, cada bem ou serviço é precificado com referência a outro bem ou serviço, o que dificulta a tomada de decisão dos agentes econômicos. A moeda, ao funcionar como referencial de comparação entre os preços, não só facilita a comparação dos valores de diferentes bens ou serviços, mas também permite a mensuração da atividade econômica de uma sociedade como um todo, aumentando a eficiência econômica ${ }^{26}$.

A função de intermediária de trocas só pode ser desempenhada de forma satisfatória se a moeda puder conservar o seu valor para as operações de troca futuras. Como corolário da função de intermediária de trocas, tem-se a função de reserva de valor.

"Na medida em que seu poder de compra é o mesmo, a moeda é instrumento de conservação de valor e constitui o objeto por excelência de aplicação da poupança: o agente econômico que acumula moeda forma estoque de poder de comprar bens ou serviços" ${ }^{27}$. O poder de compra do agente é, então, transferido para o futuro, mediante a conservação da moeda.

É claro, contudo, que a conservação do valor da moeda, apesar de desejada, não se dá de forma absoluta. Na prática, são verificadas permanentes oscilações no valor da moeda, que geram conseqüências jurídicas da maior relevância, e que devem ser levadas em consideração no estudo do preço.

\footnotetext{
${ }^{25}$ EUGÊNIO GUDIN, ob. cit., pp. 19-20.

26 Amaury Patrick Gremaud, Marco Antônio SAndoval de Vasconcellos e Rudinei Toneto JÚNIOR, Economia Brasileira Contemporânea, p. 222.

${ }^{27}$ JosÉ LUIZ BULHÕES PEDREIRA, ob. cit., p. 37.
} 


\subsection{VALOR DA MOEDA E PODER DE COMPRA.}

Durante o século XIX, prevalecia uma crença geral na supremacia e, de certo modo, na legitimidade do padrão-ouro, o que durou até a década de 1930. As nações comprometiam-se a tentar manter paridades fixas das suas moedas nacionais com relação ao ouro. Apesar das dificuldades práticas desse sistema (entre eles, a escassez do metal), a utilização do papel moeda sem o lastro era considerada imoral e repudiada ${ }^{28}$.

As próprias moedas eram cunhadas em uma porção determinada de metal ou eram emitidas pela autoridade pertinente com lastro em uma quantidade de metal depositada em cofres fortes. Considerava-se que o valor "real" da moeda estava diretamente atrelada ao metal no qual era cunhada ou que lastreava a sua emissão ${ }^{29}$. Essa crença, contudo, não resistiu diante das evidências práticas.

O sistema econômico internacional entrou em colapso na década de 1920, que culminou com a Crise de 1929 e, no contexto da crise, a manutenção do padrão-ouro tornou-se insustentável. Durante a década de 1930, os principais países do mundo foram abandonando o padrão-ouro ${ }^{30}$.

Em uma economia monetária, o valor real da moeda identifica-se com a efetiva quantidade de bens e serviços que podem ser com ela adquiridos, isto é, com o seu poder de compra ${ }^{31}$, e não com o valor do material no qual é cunhada ou com o valor nominal atribuído às moedas pelo poder emissor, o qual serve como referencial para as

${ }^{28}$ Gustavo H. B. FRANCO, Uma Longa Adolescência: fases da história monetária brasileira, pp. 6-7.

${ }^{29}$ POLANYI descreve que a crença no padrão-ouro era uma espécie de religião. Não havia muita dúvida entre os pensadores de que o valor das notas bancárias estava vinculado ao fato de que representavam o ouro. "Não fazia diferença, então, se o próprio ouro tinha valor pelo fato de incorporar trabalho, como diziam os socialistas, ou pelo fato de ser útil e escasso, como afirmava a doutrina ortodoxa. A guerra entre o céu e o inferno ignorava o tema dinheiro, deixando milagrosamente unidos capitalistas e socialistas. (...) Na verdade, a essencialidade do padrão-ouro para o funcionamento do sistema econômico internacional da época era o dogma primeiro e único comum aos homens de todas as nações, de todas as classes, de todas as religiões e filosofias sociais. Era a única realidade invisível à qual podia se apegar a vontade de viver, quando a humanidade se encontrava a braços, ela mesma, com a tarefa de restaurar sua existência em frangalhos" (ob. cit., pp. 41-42).

${ }^{30}$ Sobre o padrão-ouro e a sua substituição pelo padrão dólar-ouro, a partir do Acordo de Bretton Woods, ver a Seção 10 ("Disciplina jurídica do câmbio: histórico; circunstâncias econômicas e políticas") deste estudo.

31 Nas palavras de ASCARELLI: "Il valore della moneta, il suo potere d'acquisto, costituirà allora necessariamente un'espressione reciproca di quella del livello generale dei prezzi” [tradução livre: "O valor da moeda, seu poder de compra, constituirá então, necessariamente, uma expressão recíproca daquela do nível geral de preços”] (ob. cit, p. 14). 
trocas por elas instrumentadas, mas não exprime o efetivo poder de compra que delas decorre. O valor da moeda é medido, portanto, pelo nível geral de preços da economia e muda de forma a acompanhar as oscilações dos preços. Um aumento no nível de preços significa uma redução no valor da moeda na medida em que cada unidade monetária passa a comprar uma quantidade menor de bens e serviços ${ }^{32}$.

A teoria quantitativa da moeda afirma que o valor da moeda está relacionado à oferta e demanda de moeda que circula na economia; a quantidade de moeda disponível no mercado afeta o valor da moeda e a taxa de crescimento da quantidade de moeda disponível determina a taxa de inflação ${ }^{33}$.

A administração da quantidade de moeda que circula na economia, com o fim de controlar o nível geral de preços, é uma das principais funções de política econômica do Estado, e é exercida através, principalmente, das operações de compra e venda de títulos públicos no mercado aberto ${ }^{34}$, dos depósitos compulsórios ${ }^{35}$ e das taxas de redesconto ${ }^{36}$.

O padrão de vida de uma sociedade depende da sua produtividade, assim entendida como a capacidade que a economia tem de ofertar bens e serviços. A produtividade é determinada pelo capital físico (consistente no estoque de equipamentos e estruturas usado para produzir bens e serviços), pelo capital humano (conhecimento e habilidades adquiridos pelos trabalhadores por meio da educação, treinamento e

\footnotetext{
${ }^{32}$ N. GREGORY MANKIW, ob. cit, p. 647.

${ }^{33}$ N. GREGORY MANKIW, ob. cit, p. 649.

${ }^{34}$ Ao comprar títulos no mercado aberto (open market), o BACEN aumenta as disponibilidades de reserva dos bancos particulares e favorece a expansão do crédito. Por outro lado, quando vende títulos, causa uma diminuição das reservas dos bancos e provoca a contração do volume do crédito (ALIOMAR BALEEIRO, Uma Introdução à Ciência das Finanças, p. 479). Dessa forma, ao verificar que há muita moeda em circulação, o BACEN pode, pode meio da venda de títulos públicos no open market, promover o enxugamento desses recursos. Ao contrário, quando há escassez de moeda, a autarquia pode se apresentar como compradora dos títulos e aumentar a quantidade de moeda disponível.

${ }^{35}$ Através dos depósitos compulsórios, o BACEN determina aos bancos que depositem, no próprio BACEN, parte dos recursos captados dos seus clientes nos depósitos à vista, a prazo ou poupança. Quando reduz a parte a ser depositada de forma compulsória, o BACEN, por consequiência, permite que os bancos tenham mais recursos disponíveis para conceder crédito, o que aumenta a oferta de moeda no mercado e pode ajudar a reduzir os juros bancários. Por outro lado, quando aumenta o depósito compulsório, o BACEN promove a redução da oferta de moeda.

${ }^{36}$ Nas operações de redesconto, o BACEN funciona como emprestador de última instância dos bancos comerciais, quando esses necessitam de empréstimos de curto prazo para cumprir compromissos. A taxa de redesconto é a taxa de juros cobrada pelo BACEN nesses empréstimos. Quando o BACEN pretende aumentar a oferta de moeda no mercado, reduz a taxa de redesconto e, dessa forma, os bancos comerciais são estimulados a aumentar a quantidade de recursos disponíveis para concessão de crédito. Ao contrário, quando o BACEN aumenta a taxa de redesconto, os bancos comerciais tendem a reduzir os recursos disponíveis para empréstimo e a base monetária se contrai.
} 
experiência), pelo trabalho, pelos recursos naturais e pelo conhecimento tecnológico da sociedade (isto é, o conhecimento que a sociedade tem sobre como melhorar as técnicas de

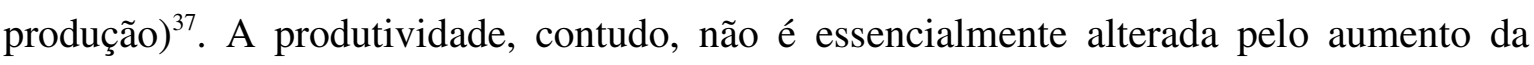
emissão de moeda.

Para melhorar o padrão de vida da sociedade, o Estado deve agir de forma a proporcionar o aumento da produtividade e, portanto, deve adotar políticas que influenciam os seus determinantes. Assim, uma das maneiras é incentivar a formação da poupança nacional, direcionando-a para investimento em bens de capital. Essa decisão implica um menor gasto em consumo corrente, ocasionando uma renúncia na satisfação de necessidades presentes para um futuro mais promissor ${ }^{38}$.

A moeda é neutra e não afeta, de forma substancial, a produção. Quando o Banco Central altera a oferta de moeda e induz alterações proporcionais no valor nominal da produção, essas alterações se refletem em alterações no nível de preços. O resultado do aumento da oferta de moeda é a inflação ${ }^{39}$.

EUGÊNIO GUDIN explica que "a expressão poder de compra da moeda induz, por vezes, à idéia errada de que a moeda cria poder de compra”. Acrescenta o autor, como mostrado acima, que "o poder de compra só é criado pela produção. Ele é gerado no

\footnotetext{
${ }^{37}$ N. GREGORY MANKIW, ob. cit, pp. 541-543.

${ }^{38}$ Como observa Leo Huberman, essa foi a decisão da Rússia, logo após a Revolução Bolchevique. Os novos detentores do poder almejavam uma economia o tão auto-suficiente quanto possível e, diante de um país pobre em bens de capital, decidiram investir pesadamente na produção desses bens, sacrificando o consumo a níveis próximos da subsistência (ob. cit, pp. 256-258). A verificação da relação entre produtividade e padrão de vida explica, ainda, a relevância dos investimentos em educação (capital humano) para o aumento do padrão de vida da sociedade no longo prazo. Observe-se que o aumento de produtividade não implica, por si, maior distribuição de renda. Questões distributivas demandam políticas específicas.

${ }^{39}$ N. GREGORY MANKIW, ob. cit, pp. 653-665. Estudos parecem indicar que o principal problema da inflação, no longo prazo, não é, ao contrário do que parece ser, uma queda no poder aquisitivo real das pessoas, uma vez que as rendas nominais tendem a acompanhar os aumentos nos preços. Alguns custos, entretanto, podem ser identificados em sociedades com alta taxa de inflação. Com o aumento da inflação, as pessoas tendem a reduzir a quantidade de moeda que mantêm como reserva de valor em suas mãos, e, como consequiência, gastam mais rapidamente seus recursos ou obrigam-se a ir aos bancos com mais frequiência. Além disso, o próprio processo de remarcação constante de preços e seu controle impõe elevado custo à sociedade (os chamados menu costs ou custos de cardápio) e, como muitas vezes, o reajuste dos preços não acompanha perfeitamente a inflação, a alocação de recursos dentro da sociedade passa a ficar distorcida. Mas, o que parece mais relevante é notar que a inflação deturpa as funções de padrão e de reserva de valor da moeda, na medida em que as pessoas passam a se confundir sobre qual o valor real da moeda e a moeda passa a não ser uma forma eficiente de se guardar riqueza. A inflação causa, ainda, uma redistribuição arbitrária da riqueza, na medida em que os custos a ela inerentes não são distribuídos de forma igualitária entre os membros da sociedade. Se, por um lado, a inflação não poderia ser apontada como a maior causa da queda no poder aquisitivo real no longo prazo, no curto prazo há uma relação negativa entre inflação e desemprego. Dessa forma, quando as autoridades monetárias contraem a oferta de moeda para controlar a inflação, a sociedade, como conseqüência, enfrenta um aumento no desemprego.
} 
esforço de trabalho e no sacrifício da economia. Ele nasce de que um indivíduo produz uma utilidade e não exige, desde logo, a recompensa equivalente, reservando-se o direito de exigi-la mais tarde. Saldo de bens e renúncia à compensação imediata são as duas condições do poder de compra"40.

A análise do valor real da moeda, portanto, está intimamente relacionada com a verificação do poder de compra que a moeda confere ao seu titular, o qual é expresso na liberdade de escolha do destino ou aplicação da moeda de que dispõe, e os efeitos, para a economia como um todo, do exercício desse poder.

A moeda confere ao seu titular autêntica liberdade, na medida em que facilita as relações de troca destinadas à satisfação das necessidades do homem. José LUIZ BULHÕES PEDREIRA explica que o agente que troca o que produz por moeda substitui seu crédito contra o comprador pelo poder jurídico de adquirir outros bens e serviços de forma indeterminada. A disponibilidade de moeda confere ao seu titular a possibilidade de adquirir quaisquer bens ou serviços, de quaisquer pessoas e a qualquer momento ${ }^{41}$, configurando expressão de liberdade.

Essa liberdade decorre dos atributos da liquidez e da procura efetiva, que qualificam a moeda e investem seu titular da condição de poder optar (situação de liquidez) entre conservá-la ou atuar nos mercados exercendo a procura por bens e serviços, influindo no comportamento dos preços (procura efetiva) ${ }^{42}$.

Nas palavras de DE CHIARA, “o atributo da liquidez ${ }^{43}$ próprio do instrumento monetário, nas relações de mercado, qualifica a situação jurídica do seu titular, e permite identificar o traço principal nas opções que resultam da detenção de somas de

${ }^{40}$ Ob. cit, p. 23.

${ }^{41}$ Ob. cit, pp. 35-36.

${ }^{42}$ JOSÉ TADEU DE CHIARA, ob. cit, p. 26. Em um aspecto macrojurídico, as trocas instrumentadas por moeda implicam a multilateralidade das relações, na medida em que seus efeitos extrapolam a relação contratual que a envolva para afetar o mercado como um todo, efeitos esses "identificados na liquidez, na propensão a consumir e nas decisões de investir em que indiscutivelmente se traduzem", e que podem explicar ou condicionar a própria decisão do particular em praticar o ato. Dessa forma, a bilateralidade dos negócios intermediados por moeda coexiste com a multilateralidade dos efeitos decorrentes daquela relação jurídica (pp. 59-61).

${ }^{43}$ AMAURY PATRICK GREMAUd, Marco ANTONIO SANDOVAl DE VASCONCEllos e RUdiNEI TONETO JÚNIOR ensinam que "liquidez é a capacidade de um ativo converter-se rapidamente em poder de compra". Ainda nas palavras dos autores, "o grau de liquidez de um ativo depende: (i) da facilidade com que ele é transacionado, o que depende da existência de mercados organizados e de suas dimensões; (ii) dos custos transacionais associados a sua negociação - condições de acesso ao mercado, tempo gasto, taxa de corretagem etc., e (iii) do grau de estabilidade e previsibilidade de seu preço". A moeda, em virtude do curso legal (do qual decorre a sua irrecusabilidade), é o ativo com maior grau de liquidez da economia (ob. cit, p. 223). 
moeda. A essas situações que resultam objetivamente da titularidade de moeda denominamos situação de liquidez"44.

Em decorrência dessa situação, o titular da moeda tem a possibilidade de atuar nos mercados, de acordo com o nível de poder de compra que decorre das suas disponibilidades de moeda, adquirindo bens e serviços. Ao fazê-lo, acaba por decidir, de forma excludente, quais os bens e serviços que optará por não adquirir.

A intermediação das trocas pela moeda faz com que os efeitos das relações extrapolem a esfera de interesse das partes envolvidas, na medida em que a real satisfação de necessidades se dá apenas com um ato posterior de troca. Ao receber moeda em pagamento de uma compra e venda, o vendedor somente satisfará suas reais necessidades ao adquirir novos bens com os recursos em moeda recebidos. A instrumentação da troca pela moeda induz, portanto, a parte a celebrar uma nova relação de troca ${ }^{45}$.

“A faceta de poder inerente à moeda é a 'influência' que é exercida nos mercados pelos titulares de disponibilidades monetárias em termos de oscilações ou ajustamentos no nível de preços, e das decisões de investir ou de consumir; e, num segundo plano, como sinalizadora das soluções políticas e de governo. A percepção do poder que decorre da titularidade de disponibilidades em moeda merece, assim, especial destaque, pois que qualifica situações jurídicas nas quais menos do que a materialização em atos de aquisição de bens por intermédio da moeda, ou do que opção entre alternativas de negócios cada vez mais amplas e diversificadas, conferem às disponibilidades financeiras especial posição de influência na dinâmica do mercado" $"$.

\footnotetext{
${ }^{44}$ JosÉ TADEU DE CHIARA, ob. cit, pp. 67-68.

${ }^{45}$ JosÉ TADEU DE CHIARA, ob. cit, pp. 58-60. Nas palavras do professor, "a função do poder de compra que se qualifica na possibilidade de os agentes atuarem nos mercados, exercendo a procura por bens e serviços (procura efetiva) ou de conservar a própria moeda (liquidez), confere ao que recebe moeda a especial condição de estar se relacionando com todos os demais agentes do mercado, em consequiência do ato de troca".

${ }^{46}$ JOSÉ TADEU DE CHIARA, ob. cit, pp. 30-31. É importante, ainda, observar a análise feita pelo professor no sentido de que, a considerar as múltiplas possibilidades de relações em uma sociedade, as quais são influenciadas pelas relações de dominação nela existentes, é insuficiente a determinação do poder de compra como uma simples relação aritmética entre quantidade de moeda e volume de bens. Na verdade, "haveria diferenças entre moedas num mesmo sistema jurídico, num mesmo padrão monetário conforme as condições do seu detentor" (p. 56-57).
} 


\subsection{CURSO LEGAL E CURSO FORÇADO DA MOEDA NACIONAL.}

O Estado, no exercício da sua soberania, determina que a moeda reconhecida como tal seja compulsoriamente aceita nos pagamentos de débitos de qualquer natureza. Tem-se, assim, o curso legal da moeda, que, na explicação de ARTHUR NuSSBAUM, designa a situação jurídica de irrecusabilidade, e que tem como consequiência a circulação obrigatória da moeda nacional ${ }^{47}$. É o poder liberatório da moeda nacional.

Diferentemente do curso legal, o curso forçado denota o caráter de inconversibilidade da moeda em metal precioso. $\mathrm{O}$ curso forçado afeta, principalmente, a possível qualidade de título de valor da moeda ${ }^{48}$.

É evidente a distinção entre o curso forçado e o curso legal ${ }^{49}$. "O curso forçado distingue-se do curso legal, pois, enquanto este toma a moeda na sua função de instrumento de troca e meio de pagamento conferindo-lhe compulsoriedade na circulação, o curso forçado diz respeito ao próprio conteúdo de valor da unidade monetária, fazendo prevalecer a expressão nominal do instrumento monetário, e impedindo a sua conversão em metal precioso". "Ao papel-moeda de aceitação geral emitido sem que haja prévio depósito de metal para lhe servir de lastro, que circula sob o regime do curso legal denomina-se moeda fiduciária. Desempenha as funções monetárias com base na confiança depositada no seu emissor sem ficar condicionada à possibilidade de conversão, ou existência de lastro" ${ }^{\circ 5}$.

O curso forçado da moeda nacional foi introduzido, no Brasil, pelo Decreto $\mathrm{n}^{\circ} 23.501$, de 27 de novembro de 1933, que suspendeu a vigência do $\S 1^{\circ}$ do artigo 947 do Código Civil Brasileiro de $1916^{51}$ e determinou a nulidade de qualquer estipulação de pagamento em ouro ou em moeda estrangeira (artigo $1^{\circ}$ ).

\footnotetext{
${ }^{47}$ Ob. cit, pp. 56 e 72.

${ }^{48}$ ARTHUR NUSSBAUM, ob. cit, p. 72.

${ }^{49} \mathrm{Na}$ lição de EUGÊNIO GUDIN, "diz-se que as notas têm curso legal, quando o credor é obrigado, por lei, a aceitá-las em pagamento. Diz-se que elas têm curso livre, quando circulam com aceitação geral, mas o credor não é obrigado, por lei, a aceitá-las em pagamento. Chama-se curso forçado ao curso legal, quando o portador não tem o direito de exigir reembolso em metal; trata-se, então, de papel-moeda inconversível" (ob. cit, pp. 51-52).

${ }^{50}$ JOSÉ TADEU DE CHIARA, ob. cit, pp. 39 e 41.

${ }^{51}$ Em sua redação original, o artigo 947 do Código Civil de 1916 dispunha que "o pagamento em dinheiro, sem determinação da espécie, far-se-á em moeda corrente no lugar do cumprimento da obrigação", mas admitia, no $\S 1^{\circ}$, ser "licito às partes estipular que se efetue em certa e determinada espécie de moeda,
} 
Conforme consta do preâmbulo do Decreto ${ }^{\circ}$ 23.501/1933, o curso forçado seria uma providência de ordem pública, tomada em caráter transitório, para evitar a depreciação da moeda nacional. Menciona ainda, o preâmbulo, que medida semelhante foi adotada por países que sofreram profundo abalo no seu sistema monetário, pela desvalorização quase total de suas moedas fiduciárias, bem como pela França, pela Inglaterra e pelos Estados Unidos ${ }^{52}$.

O Decreto $n^{\circ} 23.501 / 1933$ foi revogado pelo Decreto-lei $n^{\circ} 857$, de 11 de setembro de $1969^{53}$, ainda vigente, mas a vedação à cláusula-ouro se mantém desde 1933. Encontra-se expressamente prevista, ainda, na Lei $\mathrm{n}^{\circ} 10.192$, de 14 de fevereiro de 2001, e no atual Código Civil (artigos 315 e $318^{54}$ ).

O curso legal da moeda nacional sempre prevaleceu desde a vedação da cláusula-ouro. A recusa no recebimento da moeda de curso legal no País caracteriza contravenção referente à fé pública, nos termos da Lei das Contravenções Penais (Decretolei $\mathrm{n}^{\circ} 3.688$, de 03 de outubro de 1941).

O poder de emitir moeda passou a ser atribuído de forma exclusiva ao Estado a partir do século XIX, configurando "uma parcela do poder político, do poder do Estado, atribuído àquele que cria o instrumento monetário de acordo com regras e especificações que fazem deste instrumento monetário um elemento da ordem jurídica e que pode ser utilizado validamente no jogo dos mercados. Não é qualquer instrumento cunhado que permite a liberação dos vínculos obrigacionais, mas apenas e tão somente o que se revista das características e condições reconhecidas socialmente, e que, dessa maneira, é livremente transacionado" $" 55$.

O poder emissor exclusivo do Estado já existia desde o século XIX, mas, com a imposição do curso forçado e do curso legal da moeda nacional, esse poder alcança contornos que antes não existiam. O Estado passa a ter a prerrogativa, pelo menos

nacional ou estrangeira”. O $\S 1^{\circ}$ do artigo 947 do Código de 1916 apenas foi formalmente revogado pela Lei $\mathrm{n}^{\circ} 10.192$, de 14 de fevereiro de 2001.

${ }_{52}$ Tais medidas foram adotadas como reflexo dos problemas decorrentes da Crise de 1929.

53 Dispõe o artigo $1^{\circ}$ do Decreto-lei no 857/1969: "Art $1^{\circ}$ São nulos de pleno direito os contratos, títulos e quaisquer documentos, bem como as obrigações que exeqüíveis no Brasil, estipulem pagamento em ouro, em moeda estrangeira, ou, por alguma forma, restrinjam ou recusem, nos seus efeitos, o curso legal do cruzeiro." ${ }^{54}$ O Código Civil vigente dispõe que as dívidas em dinheiro deverão ser pagas no vencimento, em moeda corrente e pelo valor nominal e que são nulas as convenções de pagamento em ouro ou em moeda estrangeira, bem como aquelas que visam compensar a diferença entre o valor desta e o da moeda nacional, excetuados os casos previstos na legislação especial (artigos 315 e 318).

55 José TADEU DE CHIARA, ob. cit, p. 18. 
teoricamente, de emitir moeda de forma ilimitada, sem a necessidade de lastro. Por conseqüência do curso legal, a moeda tem aceitação obrigatória, e com ela o Estado pode pagar seus servidores, fazer investimentos, ou arcar com quaisquer outros gastos que lhe pareçam oportunos. Em última instância, o Estado passa a poder emitir moeda, ilimitadamente, pelo menos em tese, para custear seu próprio déficit. A importância dessa prerrogativa fica ainda mais evidente quando se percebe a relação entre a quantidade de moeda que circula na economia e o controle do nível de preços, conforme destacado na Seção 1.4 supra ("Valor da moeda e poder de compra").

\section{CÂMBIO.}

\subsection{MOEDA ESTRANGEIRA.}

A moeda, como já tratado na Seção 1.2 ("Conceito de moeda”), é unidade ideal determinada como tal pelo ordenamento jurídico sob o qual é emitida, dentro dos limites de soberania do Estado que a emite. A moeda apenas terá todas as funções que lhe são peculiares dentro de uma ordem jurídica que assim o determine.

O Estado, a partir do curso legal, determina que os pagamentos realizados em território nacional devam necessariamente ser feitos na moeda local. Impõe, assim, a circulação obrigatória da unidade monetária por ele emitida e restringe a utilização de moedas estrangeiras dentro do território nacional às situações fixadas na ordem jurídica.

Ao perder as características que lhe são típicas, a moeda estrangeira não é verdadeiramente considerada moeda fora da ordem jurídica que a criou. A melhor doutrina reconhece que a moeda transforma-se, assim, em uma ordem jurídica que lhe é estranha, em bem ou mercadoria ${ }^{56}$.

\footnotetext{
${ }^{56}$ Esse parece ser o entendimento de TULLIO ASCARELLI, ao indicar que, em um contrato de câmbio, a moeda estrangeira é considerada como mercadoria (ob. cit., p. 41). Também nesse sentido - ou seja, de que a moeda estrangeira é mercadoria no âmbito de ordem jurídica que lhe é estranha - posiciona-se JOSÉ TADEU DE ChIARA (ob. cit., p. 150). Leciona o professor que "a moeda estrangeira ao perder a natureza de moeda no plano interno da ordem jurídica dos Estados, transforma-se em mercadoria. Isto porque, dado revestir-se das qualidades de elemento patrimonial que indiscutivelmente atribui um valor econômico ao seu titular, integra-
} 
ARTHUR NuSSBAUM defende que, por regra geral, as unidades monetárias estrangeiras não são consideradas moeda ou dinheiro dentro de um país, pois a moeda goza, frente a outras coisas, uma posição privilegiada que o legislador não concede à moeda estrangeira. Ao legislador interessa proteger, em verdade, a circulação da moeda nacional e está fora de dúvida que a estipulação de restrições à utilização de moeda estrangeira está englobada na soberania de cada Estado. Na medida em que não são consideradas moedas, as moedas estrangeiras devem ser consideradas como mercadorias ${ }^{57}$.

Para que o titular da moeda estrangeira possa exercer as prerrogativas de titular de moeda deverá, necessariamente, convertê-la em moeda nacional.

Como mercadoria, a moeda estrangeira, poderia, em princípio, ser objeto de troca. Entretanto, em virtude das restrições impostas à sua circulação (especialmente, como já destacado, o curso legal da moeda, que impõe a irrecusabilidade da moeda nacional), a moeda estrangeira caracteriza-se como mercadoria de caráter diferenciado e somente pode ser objeto de "troca" por moeda nacional, e não por qualquer outro tipo de bem. Não pode, ainda, ser utilizada como meio de pagamento ${ }^{58}$.

A conversão da moeda estrangeira pela moeda nacional se dá através da celebração de contrato de câmbio, observando-se as normas cambiais vigentes, como será abordado a seguir.

\subsection{CONTRATO DE CÂMBIO.}

Para que o titular de moeda estrangeira possa se investir em situação de liquidez (tal como apresentada por DE CHIARA, como visto na Seção 1.4 acima - "Valor da moeda e poder de compra"), deve necessariamente convertê-la ou "trocá-la" por moeda nacional. Através do contrato de câmbio, o domínio da moeda estrangeira é transferido a outrem mediante a entrega ao titular original da moeda estrangeira de certa quantia em moeda nacional.

lhe o patrimônio pela inegável situação de liquidez que dela resulta em relação aos mercados abrangidos na ordem jurídica que a define como moeda".

${ }^{57}$ Ob. cit., pp. 85-88.

${ }^{58}$ JOSÉ TADEU DE CHIARA, ob. cit., p. 150. 
O contrato de câmbio caracteriza-se, pois, como contrato de compra e venda $^{59}$. Como tal, é acordo bilateral, consensual, que se aperfeiçoa com o acordo das partes, tendo por objeto a compra e venda de um bem (que, no caso, é a moeda estrangeira), mediante o pagamento de um preço em moeda nacional, determinado pela taxa de câmbio ${ }^{60}$.

FÁBIO KONDER COMPARATO confirma que "a opinião mais acatada e difundida entre os doutrinadores, desde o fim da Idade Média, é a de que o contrato de câmbio se assemelha à compra e venda. (...) No câmbio, a moeda transforma-se de instrumento de pagamento em mercadoria, isto é, um bem econômico sujeito ao mercado e submetido à lei da oferta e da procura" ${ }^{\prime 1}$.

Os contratos são um dos pilares fundamentais do sistema capitalista, na medida em que é, através da sua celebração, que a circulação mercantil é realizada. No modelo ideal de liberalismo econômico, as partes possuem irrestrita liberdade no ato de contratar, que se traduz na decisão de contratar ou não, bem como na de determinar o conteúdo do negócio jurídico ${ }^{62}$.

A conformação das relações contratuais implica a conformação da própria realidade econômica e é, a partir dessa constatação, que o Estado passa a intervir no regime dos contratos, impondo restrições às partes.

Em virtude da importância que as operações cambiais representam para a política econômica do Estado, o que impõe o controle e a fiscalização do fluxo de divisas

\footnotetext{
${ }^{59}$ Dispõe o artigo 481 do Código Civil de 2002 que "pelo contrato de compra e venda, um dos contratantes se obriga a transferir o domínio de certa coisa, e o outro, a pagar-lhe certo preço em dinheiro." O Código Comercial, na $2^{\mathrm{a}}$ alínea do seu artigo 191, incluía expressamente entre os contratos de compra e venda mercantil aqueles que tinham por objeto a moeda metálica e o papel-moeda.

${ }^{60}$ Em artigo intitulado $O$ Contrato de Câmbio, Haroldo MALheIros DuClerc Verçosa cita alguns pensadores com opiniões diversas sobre a natureza jurídica do contrato de câmbio. Propõe o autor que a análise parta da verificação da função econômico-social do negócio como critério orientador e conclui que o negócio deve ser, nesse sentido, considerado compra e venda ou permuta. Observa que a única diferença entre a compra e venda e a permuta é que naquela a transferência da propriedade de um bem se dá mediante o pagamento do preço e que, na segunda, essa transferência se dá mediante a cessão de outro bem. Dessa forma, o contrato de câmbio seria permuta ou compra e venda, dependendo se se considerasse ambas as moedas como bens ou somente uma delas como bem. Tendo em vista o disposto no artigo 533 do Código Civil, o qual determina a aplicação, às permutas, das disposições relativas à compra e venda, a solução jurídica, no direito brasileiro, para quaisquer questões seria a mesma em praticamente todos os casos, independentemente de se considerar o contrato de câmbio como compra e venda ou permuta.

${ }^{61}$ Contrato de Câmbio, p. 55. Tullio AsCarelli, da mesma forma, entende ser o contrato de câmbio um contrato de compra e venda (ob. cit., p. 415).

${ }^{62}$ EROS Roberto GRAU, A Ordem Econômica na Constituição de 1988 (interpretação e crítica), pp. 95-101.
} 
do e para o País, e tendo-se em consideração o curso legal da moeda nacional, o Estado impõe restrições e determina a configuração dos contratos de câmbio.

Em primeiro lugar, o contrato de câmbio deve ser necessariamente celebrado com uma instituição autorizada a operar no mercado de câmbio ${ }^{63}$ pelo BACEN ${ }^{64}$. Ou seja, aquele que dispõe de moeda estrangeira e pretende obter moeda nacional ou, se ao contrário, dispõe de moeda nacional e pretender realizar pagamentos no exterior em moeda estrangeira, deve celebrar o respectivo contrato de câmbio com instituição autorizada pelo BACEN a operar no mercado de câmbio ${ }^{65}$.

O Estado impõe, assim, a obrigatoriedade de celebração do contrato de câmbio para que o titular da moeda estrangeira possa investir-se da situação de liquidez, e restringe a possibilidade de celebração do contrato do contrato com instituições autorizadas, pelo próprio Estado, a atuar no mercado de câmbio.

Nos termos do inciso VIII do artigo 10 da Lei ${ }^{\circ} 4.595$, de 31 de dezembro de 1964, o BACEN tem competência privativa para ser depositário das reservas oficiais de ouro e moeda estrangeira do País. Isso significa dizer que apenas podem realizar operações de câmbio as instituições previamente autorizadas pelo BACEN e que, ao final do período determinado, as instituições que atuam no mercado de câmbio devem apresentar-se ao

${ }^{63}$ A Resolução CMN no 3.568, de 29 de maio de 2008, dispõe que "o mercado de câmbio brasileiro compreende as operações de compra e venda de moeda estrangeira e as operações com ouro-instrumento cambial, realizadas com instituições autorizadas pelo Banco Central do Brasil a operar no mercado de câmbio, bem como as operações em moeda nacional entre residentes, domiciliados ou com sede no País e residentes, domiciliados ou com sede no exterior" (artigo $1^{\circ}$ ).

64 A obrigatoriedade da celebração das operações de câmbio com instituições autorizadas está prevista no artigo 23 da Lei $n^{\circ} 4.131$, de 03 de agosto de 1962, e foi reafirmada nos termos do Regulamento do Mercado de Câmbio e Capitais Internacionais, divulgado pelo BACEN por meio da Circular $n^{\circ} 3.280$, de 09 de março de 1995 (Regulamento de Câmbio). A realização de câmbio com instituições não autorizadas caracteriza operação ilegítima de câmbio, infração prevista no Decreto ${ }^{\circ} 23.258$, de 19 de outubro de 1933. De acordo com a Resolução CMN no 3.568/2008, o BACEN pode conceder autorização para atuar no mercado de câmbio a bancos múltiplos, bancos comerciais, caixas econômicas, bancos de investimento, bancos de desenvolvimento, bancos de câmbio, sociedades de crédito, financiamento e investimento, sociedades corretoras de títulos e valores mobiliários, sociedades distribuidoras de títulos e valores mobiliários e sociedades corretoras de câmbio (artigo $2^{\circ}$ ). Observe-se que essas instituições podem contratar, mediante convênio, (i) pessoas jurídicas em geral, para negociar a realização de transferências unilaterais, do e para o exterior, na forma definida pelo BACEN; (ii) pessoas jurídicas cadastradas, na forma da regulamentação em vigor, no Ministério do Turismo, como prestadores de serviços turísticos remunerados, para a realização de operações de compra e venda de moeda estrangeira em espécie, cheques ou cheques de viagem; (iii) instituições financeiras e demais instituições autorizadas a funcionar pelo BACEN, não autorizadas a operar em câmbio, para realização de transferências unilaterais e compra e venda de moeda estrangeira em espécie, cheques ou cheques de viagem $\left(\operatorname{artigo} 4^{\circ}\right.$ ).

${ }^{65}$ As instituições autorizadas a celebrar as operações de câmbio devem incluir diariamente, em sistema eletrônico (Sistema de Informação Banco Central - SISBACEN), informações sobre as operações cursadas, o que permite ao BACEN acompanhá-las no exercício da sua competência fiscalizatória, bem como para respaldar suas decisões no exercício da política monetária. 
BACEN para negociação de moeda estrangeira (ou seja, para comprar ou vender a moeda estrangeira, dependendo da sua posição) de forma a que suas reservas fiquem dentro dos limites estabelecidos pela autoridade monetária ${ }^{66}$.

Adicionalmente, as partes encontram limitações no que se refere ao conteúdo dos contratos de câmbio, que é determinado de antemão pela autoridade monetária mediante modelo por ela divulgado ${ }^{67}$. Nesse modelo, estão determinadas as cláusulas obrigatórias do contrato de câmbio, entre elas a informação sobre a natureza da operação.

A natureza da operação indica o negócio ou fato subjacente à operação de câmbio contratada. Por exemplo, um contrato de câmbio celebrado para pagamento de uma exportação tem, como negócio subjacente, a operação comercial de que se trata (ou, melhor dizendo, a compra e venda mercantil entre o exportador brasileiro e o adquirente estrangeiro $)^{68}$. Da mesma forma, um contrato de câmbio classificado como transferência de patrimônio para o exterior tem como fato subjacente a mudança de residência, para fora do País, da parte que remete os recursos ao exterior.

A indicação, no contrato de câmbio, da natureza da operação subjacente obedece a um Código de Classificação divulgado pelo $\mathrm{BACEN}^{69}$. É responsabilidade do cliente informar corretamente à instituição o negócio ou fato que respalda a operação. Por

\footnotetext{
66، O objetivo dessa norma é evitar a possibilidade de manobras especulativas no mercado em que operam as instituições autorizadas à prática das operações da espécie que inibiram a administração da taxa de câmbio. Daí decorre o princípio regulador das operações cambiais, segundo o qual toda a moeda estrangeira adquirida deve ser vendida, e se não o for para aqueles que dela necessitem ou para outras instituições, compulsoriamente deve ser vendida para o Banco Central nas denominadas operações de repasse. Por outro lado, se as vendas de moeda estrangeira excederem as disponibilidades da instituição, esta, se não conseguir adquirir o montante do excesso no mercado interbancário, deverá obrigatoriamente socorrer-se da cobertura do Banco Central" (José TAdeu De ChiARA, ob. cit., pp. 156-157). Atualmente, o Regulamento de Câmbio prevê que não há limite para as posições de câmbio comprada ou vendida dos bancos e caixas econômicas autorizados a operar no mercado de câmbio, bem como que não há limite para a posição de câmbio comprada das demais instituições autorizadas a funcionar pelo BACEN, sendo a posição vendida limitada a zero (Título 1, Capítulo 5, Seção 1, Itens 6 e 8). A exposição em ouro, em moeda estrangeira e em operações sujeitas à variação cambial das instituições financeiras e demais instituições autorizadas a funcionar pelo BACEN está limitada a $30 \%$ do patrimônio de referência, conforme o disposto na Resolução CMN n 3.488 , de 29 de agosto de 2007.

${ }^{67} \mathrm{O}$ Regulamento de Câmbio prevê que "a formalização das operações de câmbio deve seguir os modelos dos anexos 1 a 11 deste título (...)” (Título 1, Capítulo 3, Seção 1, Item 3). FÁBio Konder Comparato entende que esses contratos se apresentam como típicos contratos de adesão (Contrato de Câmbio, p. 56).

${ }^{68}$ JosÉ TADEU De CHIARA, ob. cit., p. 160.

${ }^{69}$ Ver o Regulamento de Câmbio, Título 1, Capítulo 8, Seção 1, Item 1 e Título 1, Capítulo 8, Seção 2, Subseção 1, Item 1.
} 
outro lado, as instituições são responsáveis pela correta classificação das operações, dentro dos códigos divulgados pelo $\mathrm{BACEN}^{70}$.

O preço de compra ou venda da moeda estrangeira é expresso no contrato de câmbio através da taxa de câmbio ${ }^{71}$, sobre a qual discursaremos adiante.

\subsection{TAXA DE CÂMBIO.}

O poder de compra real de uma determinada moeda é expressão do produto social gerado sob a ordem jurídica que a criou. Nas relações internacionais, o poder de compra de uma moeda é determinado pela quantidade de moeda estrangeira que com ela pode ser adquirida.

A taxa de câmbio é o preço pela compra e venda de moeda estrangeira instrumentada pelo contrato de câmbio e refere-se à relação de troca entre a moeda nacional e a moeda estrangeira. A taxa de câmbio nominal corresponde à taxa pela qual uma pessoa pode trocar moeda de um país pela de outro, já a taxa de câmbio real consiste naquela pela qual uma pessoa pode trocar os bens e serviços de um país pelos bens e serviços de outro país ${ }^{72}$.

A taxa de câmbio permite, por conseqüência, que os preços dos mesmos produtos em diferentes países, os quais são referenciados em moedas diversas, possam ser comparados. A maioria das operações internacionais envolve a troca de moedas por dólar norte-americano, ainda que a operação subjacente não seja estipulada em dólar. Por

\footnotetext{
${ }^{70}$ Conforme o disposto nos parágrafos $3^{\circ}$ e $4^{\circ}$ do artigo 23 da Lei $n^{\circ} 4.131 / 1962$. Trataremos das infrações cambiais relacionadas às obrigações de fornecimento de informações sobre a identidade das partes dos contratos de câmbio e sobre a legitimidade das operações subjacentes, bem como de sua correta classificação, na Seção 12.4 ("Infrações cambiais") e subseções.

${ }^{71}$ Existem algumas classificações possíveis das operações de câmbio, as quais não serão exploradas neste trabalho. A mais utilizada divide as operações de câmbio em câmbio manual, no caso das operações que envolvem a negociação de diferentes moedas em espécie, ou câmbio sacado ou trajetício, nas quais uma parte entrega os recursos na moeda local do seu país à instituição com o qual está celebrando a operação e a instrui a realizar o depósito no valor em moeda estrangeira correspondente ao beneficiário no exterior. Como se pode imaginar, as operações de relevo são realizadas como câmbio trajetício. Nesses casos, em virtude da presença do elemento fundamental de distância entre a parte que celebra a operação e o seu beneficiário, está presente a distinção entre fechamento da operação, que designa a celebração do contrato, e a liquidação, correspondente à entrega dos respectivos recursos pela parte obrigada a prestar a moeda estrangeira. Para uma exposição sobre as classificações das operações cambiais, ver HAROLDO MALHEIROS VERÇOSA, $O$ Contrato de Câmbio, p. 27; e Renato A. Gomes DE SouzA, Câmbio: Dos Controles Rígidos à Liberalização, p. 1.

${ }^{72}$ N. GREGORY MANKIw, ob. cit., pp. 685-688.
} 
exemplo, trocam-se francos suíços por dólar para, posteriormente, trocá-los por ienes, em vez de se realizar a troca direta entre os francos suíços por ienes. Isso ocorre pois, em razão da relevância que a economia dos Estados Unidos da América representa nos negócios internacionais e do enorme volume de operações envolvendo o dólar, é mais barato e eficiente que as operações sejam referenciadas naquela moeda. Nos últimos anos, a importância do euro tem aumentado, mas as operações envolvendo o dólar ainda $\operatorname{predominam}^{73}$.

A teoria da paridade do poder de compra propugna que uma mercadoria deve sempre custar o mesmo quando medida na mesma moeda. De acordo com essa teoria, a lei da oferta e da demanda, aplicada ao mercado mundial, tenderia a proporcionar um preço de equilíbrio único independentemente do país em questão. Portanto, a taxa de câmbio nominal entre as moedas de dois países dependeria da diferença dos níveis de preços nesses países ${ }^{74}$.

A teoria da paridade do poder de compra enfrenta limitações. Em realidade, a relação de troca entre a moeda nacional e a moeda estrangeira expressada na taxa de câmbio não pode ser explicada apenas pela paridade real entre os poderes de compra de cada uma delas.

Em primeiro lugar, muitos bens e serviços não são facilmente comercializados e a arbitragem dos preços necessária para garantir que os preços fossem alterados através da oferta e da demanda até encontrarem um equilíbrio ficaria prejudicada. Por outro lado, mesmo os bens facilmente comercializáveis não são substitutos perfeitos quando produzidos em países diferentes. Outros fatores, ainda, devem ser levados em consideração para essa análise, como o interesse dos compradores da moeda, as medidas de política econômica adotadas pelos Estados e os efeitos da relação internacional de troca entre os Estados ${ }^{75}$.

Gustavo H. B. Franco ensina que, a partir da adoção do regime de câmbio de taxas flutuantes nos países anglo-saxões nos anos 1970 e 1980, foi possível constatar a

\footnotetext{
${ }^{73}$ PAUl R. KRUGMAN e MAURICE OBSTFELd, Economia Internacional: teoria e política, pp. 246-247.

${ }^{74}$ N. GREGORY MANKIW, ob. cit., pp. 688-691.

75 A relação internacional de troca engloba as alternativas para a venda dos produtos nacionais em concorrência com produtos de outros países. Como ensina DE CHIARA, "os custos de produção, a utilidade dos bens, e os efeitos da concorrência influenciam de maneira acentuada os preços dos bens comercializados e a participação do Estado nessas relações de comércio" (ob. cit., p. 153).
} 
inadequação da teoria da paridade do poder de compra, que dava ênfase excessiva ao papel dos fluxos. As novas teorias revelaram a importância do papel dos estoques de riqueza ou dívidas na determinação da taxa de câmbio ${ }^{76}$.

Nas palavras de DE CHIARA, "as trocas que se realizam nos mercados internacionais exprimem o posicionamento interno do sistema produtivo de cada Estado e, ao mesmo tempo, implicam condicionamentos para a política econômica e a própria administração da moeda e do crédito. Nesse ponto devem ser consideradas as restrições e peculiaridades da disciplina das operações cambiais, especialmente no que diz respeito à taxa de câmbio (...)" ${ }^{, 77}$.

A taxa de câmbio é, de fato, determinada pelas forças do mercado, pela relação internacional de troca e pela atuação dos Estados. Em virtude dos diversos condicionamentos que influenciam na sua formação, a noção de equivalência, que é intrínseca ao preço na compra e venda, fica prejudicada ao tratarmos da taxa de câmbio ${ }^{78}$.

Atualmente, no Brasil, as partes, ao celebrarem operações de câmbio, podem livremente pactuar a taxa de câmbio a ser praticada ${ }^{79}$. A lei da oferta e da procura exerce sua influência na determinação da taxa praticada no mercado. Dessa forma, em épocas de grande demanda por moeda estrangeira, quando crescem os fluxos de recursos do Brasil para o exterior, é natural que a moeda nacional tenda a se depreciar. Se, por outro lado, os ingressos de recursos no País aumentam, cresce a oferta de moeda estrangeira, o que causa uma tendência de apreciação da moeda nacional frente à moeda estrangeira.

A atuação do Estado, através dos controles cambiais ou agindo no mercado (comprando e vendendo moeda estrangeira ou títulos indexados em moeda estrangeira ou realizando operações no mercado de derivativos), influencia a formação da taxa de câmbio.

\footnotetext{
${ }^{76}$ Crônicas da Convergência: ensaios sobre temas já não tão polêmicos, pp. 321-322. Trataremos dos regimes cambiais na Seção 6.1, adiante.

77 Ob. cit., p. 149.

78 JOSÉ TADEU DE CHIARA, ob. cit., p. 155.

${ }^{79}$ Artigo 19 da Resolução CMN no 3.568, de 29 de maio de 2008. A rigor, coexistem, no País, duas taxas de câmbio: a praticada no mercado de câmbio oficial e aquela adotada no mercado paralelo. Como se verá no Capítulo IV, o mercado negro de câmbio já teve uma enorme representatividade, quando vigoravam rígidos controles sobre as operações cambiais. Uma das explicações oficiais para a chamada "flexibilização" das normas cambiais, que vem sendo implementada desde o final da década de 1980, é justamente diminuir a importância do mercado negro de câmbio, trazendo para o campo de visão da autoridade monetária as operações cuja origem seja legítima.
} 
A administração da taxa de câmbio pelo Estado é ato de política econômica e, como tal, deve condizer com os objetivos de política pública fixados pelo ordenamento jurídico. O nível dessa atuação estatal depende do regime cambial adotado, como será explorado no próximo capítulo.

\section{Como leciona De CHIARA,}

"[A] disciplina da taxa de câmbio como comparação quantitativa entre moeda nacional e moeda estrangeira para fins de compra e venda é definida em termos de se implementarem vendas para o exterior, de incentivar o desenvolvimento das estruturas produtivas internas; ou, em sentido contrário, de se facilitarem compras no exterior e a importação de bens necessários para organizar o sistema produtivo interno. Tais considerações demonstram em linhas gerais que a administração da taxa de câmbio é presidida pelos objetivos da política econômica do Estado sob balizamentos da conjuntura do comércio internacional” ${ }^{\prime 80}$.

${ }^{80}$ Ob. cit., p. 154. 


\title{
ATUAÇÃO DO ESTADO NO E SOBRE O PROCESSO ECONÔMICO
}

\author{
SumÁrio: 3. Constituição econômica e ordem econômica. - 4. Política \\ econômica. - 5. As formas de atuação do Estado no e sobre o processo \\ econômico. - 6. Atuação do Estado no câmbio. - 6.1. - Regimes \\ cambiais. - 6.2. Controles cambiais.
}

\section{CONSTITUIÇÃO ECONÔMICA E ORDEM ECONÔMICA.}

O Estado Moderno foi concebido, a partir do final do século XVII, como uma organização rígida e estática, fundada na norma geral e abstrata, substituindo a vontade individual do monarca, que marca o absolutismo, pelo império da lei. Com a consolidação do Estado Moderno, o poder legislativo ganha especial destaque, na medida em que lhe compete determinar os caminhos a serem perseguidos por uma dada sociedade. Cabe ao poder executivo a execução das normas de caráter geral criadas pelo poder legislativo (e não efetivamente criá-las). Enquanto regra geral e suprema, a lei se torna passível de poucas modificações e não é alterável de acordo com a conjuntura ${ }^{81}$.

Essa mudança na estruturação do poder atende aos anseios dos novos detentores do poder econômico, ao conferir um caráter institucional e impessoal aos ditames da ordem e ao garantir o cálculo e a previsibilidade necessários para desenvolvimento das relações mercantis ${ }^{82}$.

Até o início do século $\mathrm{XX}$, ao Estado estavam atribuídas principalmente as funções de segurança e produção do direito. No campo econômico, a posição assumida

\footnotetext{
${ }^{81}$ FÁBIo Konder Comparato, Ensaio sobre o Juízo de Constitucionalidade de Políticas Públicas, p. 51.

${ }^{82}$ EROS ROBERTO GRAU observa que o cálculo e a previsibilidade são garantidos pela generalidade e abstração da lei, garantindo os agentes econômicos contra o Estado (liberalismo político) e contra os outros agentes econômicos (liberalismo econômico) (A Ordem Econômica na Constituição de 1988 (interpretação e crítica), p. 38).
} 
pelo Estado era, predominantemente, de ausência e omissão ${ }^{83}$. O papel do Estado liberal, pelo menos em uma perspectiva teórica, era abster-se de atuar no domínio econômico, deixando os particulares livres para exercer as atividades econômicas da forma como melhor quisessem ${ }^{84}$.

EROS Roberto Grau chama a atenção que, na verdade, o Estado, desde o seu nascimento, tinha vocação para atuar no campo econômico. A própria constituição do modo de produção capitalista deu-se, em grande parte, pela atuação do Estado, ao garantir a existência das condições básicas necessárias ao seu desenvolvimento.

O que mudou, após o início do século XX, foi a forma de atuação do Estado. Nos primórdios de sua formação, o Estado moderno voltava-se primordialmente a garantir a constituição e preservação do modo de produção capitalista ${ }^{85}$. Sob os cânones do liberalismo, entendia-se que o Estado não deveria interferir nas relações econômicas, mas deixar que o seu desenvolvimento ocorresse naturalmente no seio da sociedade. A mão invisível do mercado daria conta de equilibrar as relações com ganhos para toda a coletividade.

\section{ALBERTO VenÂNCIO FILHO explica:}

“[D]urante todo o transcorrer do século XIX, importantes transformações econômicas e sociais vão profundamente alterar o quadro em que se inseria esse pensamente político-jurídico. As implicações cada vez mais intensas das descobertas científicas e de suas aplicações, que se processam com maior celeridade, a partir da Revolução Industrial, o aparecimento de gigantescas empresas fabris, trazendo, em consequiência, a formação de grandes aglomerados urbanos, representam mudanças profundas na vida social e política dos países, acarretando alterações acentuadas nas relações sociais, o que exigirá que paulatinamente, sem nenhuma posição doutrinária preestabelecida, o Estado vá, cada vez mais, abarcando maior número de atribuições, intervindo mais

\footnotetext{
${ }^{83}$ Alberto VenÂNCIO Filho, A Intervenção do Estado no Domínio Econômico: o direito público econômico no Brasil, p. 4.

${ }^{84}$ ALBERTO VENÂNCIO FILHO demonstra que, por circunstâncias peculiares à nossa história, não passamos, no Brasil, por um sistema liberal típico, com a predominância da ausência do Estado na vida econômica. Ajudam a explicar esse fenômeno a vinda da família real Portuguesa para o Brasil em 1808, a conseqüente transferência da máquina administrativa portuguesa para nossas terras, e o fato de ter sido montada uma estrutura administrativa que priorizava a arrecadação tarifária para envio à coroa portuguesa (ob. cit., pp. 2139)

${ }^{85}$ ERos Roberto GraU, A Ordem Econômica na Constituição de 1988 (interpretação e crítica), pp. 18-19.
} 
assiduamente na vida econômica e social, para compor os conflitos de interesses de grupos e de indivíduos" ${ }^{, 86}$.

A partir das sucessivas crises envolvendo os países capitalistas e das desigualdades cada vez maiores, ficou claro que o ideal de não interferência na economia propugnado pelo liberalismo não se sustentaria. A livre atuação que, na opinião dos liberais, produziria um mercado competitivo com ganhos para toda a sociedade, acabou por criar as condições para a concentração do poder econômico, sob a forma de monopólios e cartéis, com inevitáveis abusos. A livre contratação de mão-de-obra desencadeou as condições subumanas a que os trabalhadores foram submetidos na época da Revolução Industrial e que ainda hoje podem ser identificadas. O liberalismo conseguiu colocar em relevo, em realidade, as profundas fissuras sociais que resultam do capitalismo desordenado ${ }^{87}$.

É nesse contexto, com a ocorrência de crises e a constatação da existência de assimetrias que poderiam comprometer a própria existência do sistema, que o Estado passa, a partir do início do século passado, notadamente após o fim da Primeira Guerra Mundial, de garantidor apenas do direito e da segurança a buscar declaradamente conter as fissuras do capitalismo. Fica, por conseguinte, evidente uma das maiores contradições das economias de mercado: ao mesmo tempo em que precisam da atuação estatal para garantir o desenvolvimento das relações mercantis, demandam que essa atuação seja reduzida ao seu mínimo ${ }^{88}$.

\footnotetext{
${ }^{86}$ Ob. cit., p. 8. O autor coloca, ainda, o despertar da consciência do subdesenvolvimento como um dos fatores a exigir a maior presença do Estado no domínio econômico, nos seguintes termos: "Se a todos esses fatores adicionarmos, após a Segunda Guerra Mundial, o esforço de independência dos países afro-asiáticos e o despertar dos povos coloniais, com uma consciência cada vez mais viva do fenômeno do subdesenvolvimento e da necessidade de superá-lo em curto prazo, e com o desejo das populações desses países de atingir a níveis mais elevados de renda e de bem-estar social, ter-se-á mais uma condicionante da intervenção do Estado no domínio econômico" (p. 14).

${ }^{87}$ Como bem demonstrado por EROS ROBERTO GRAU, "à idealização de liberdade, igualdade e fraternidade se contrapôs a realidade do poder econômico". A liberdade econômica traduziu-se na supressão da concorrência. A igualdade ficou limitada ao plano formal. A fraternidade não encontrou seu lugar em uma sociedade em que o egoísmo e a competição são os motores da atividade econômica (A Ordem Econômica na Constituição de 1988 (interpretação e crítica), pp. 22-25).

${ }^{88}$ ERos Roberto GraU, A Ordem Econômica na Constituição de 1988 (interpretação e crítica), pp. 19-21. Mais adiante, o autor esclarece que "o capitalismo [leia-se: o Terceiro Estado, a burguesia] necessita da ordem, mas a detesta, procurando a qualquer custo exorcizá-la. Dizendo-o de outro modo: o mercado exige, para satisfação do seu interesse, o afastamento ou a redução de qualquer entrave social, político ou moral ao processo de acumulação de capital. Reclama atuação estatal para garantir a fluência das relações, porém, ao mesmo tempo, exige que essa atuação seja mínima” (pp. 36-37).
} 
Às funções de constituição e preservação do modo de produção capitalista desempenhadas pelo Estado, como mencionado acima, somaram-se aquelas de complementar o mercado (criação de novas instituições do sistema mercantil, por exemplo), substituir do mercado (possibilidades de inversão ou criação de novas formas de produzir a mais-valia) e compensar do mercado (minimização dos efeitos externos do capitalista - dano ao meio ambiente, garantia de sobrevivência de setores ameaçados) ${ }^{89}$.

O Direito, por sua vez, que no Estado liberal tinha primordialmente a função de declarar a ordem das coisas, passa, no Estado pós-liberal, a determinar os fins sociais eleitos pela sociedade e a funcionar como instrumento para a sua consecução. Nesse contexto, ganha importância a regulação das situações conjunturais ${ }^{90}$.

Acompanhando o processo de expansão das funções do Estado ao atuar no domínio econômico, as Constituições, a partir do início do século passado, passam a tratar explicitamente da ordem econômica ${ }^{91}$, conferindo ao Estado atribuições para agir sobre e na vida econômica e determinando limites e objetivos para essa atuação ${ }^{92}$. São as chamadas Constituições Econômicas.

Nas Constituições Brasileiras, o sistema econômico individualista-liberal sempre prevaleceu, mediante a consagração da propriedade privada individual e da liberdade individual como garantias supremas ${ }^{93}$.

\footnotetext{
${ }^{89}$ De acordo com JUERGEN HABERMAS, após o estabelecimento do modo de produção capitalista, "o exercício do poder do Estado dentro do Sistema social pode ser limitado: (a) proteção do comércio burguês de acordo com o direito civil (polícia e administração da justiça); (b) para a proteção do mecanismo de mercados dos efeitos laterais auto-destrutivos (por exemplo, legislação para proteção do trabalho); (c) a satisfação dos pré-requisitos de produção na economia como um todo (educação escolar pública, transporte e comunicação) e (d) para a adaptação do sistema de direito civil as necessidades que emergem do processo de acumulação (tributação, rede bancária e direito comercial). Cumprindo estas quatro espécies de tarefas, o Estado assegura os pré-requisitos estruturais do processo de reprodução enquanto processo capitalista" ( $A$ Crise de Legitimação no Capitalismo Tardio, pp. 34-35).

${ }^{90}$ FÁBIO KONDER COMPARATO, Ordem Econômica na Constituição de 1988, p. 264.

${ }^{91}$ Gilberto BerCOVICI esclarece que a Constituição Mexicana, de 5 de fevereiro de 1917, destacou direitos sociais e incorporou dispositivos sobre a função social da propriedade, mas sua influência se fez sentir de forma mais contundente na América Latina. A Constituição de Weimar de 1919 é apresentada como a mais célebre das novas Constituições e que influenciou o maior número de textos constitucionais posteriores, inclusive a Carta Magna Brasileira de 1934 (Constituição Econômica e Desenvolvimento: uma leitura a partir da Constituição de 1988, pp. 13-14).

${ }_{92}$ MANUAL GONÇALVES FERREIRA FILHO chama atenção que, em um primeiro momento, as Constituições surgidas sob a influência da Constituição de Weimar de 1919 preocupavam-se mais em garantir aos indivíduos os direitos necessários ao gozo de liberdades públicas e estabelecer a organização política do Estado do que propriamente em organizar a economia (Direito Constitucional Econômico, p. 5).

93 JoSAPHAT MARINHO, A Ordem Econômica nas Constituições Brasileiras, p. 51.
} 
Em consonância com as doutrinas predominantes do seu tempo, as Constituições de 1824 e de 1891 nasceram comprometidas com o liberalismo. Não há preocupação, naqueles diplomas, em se regular especificamente a ordem econômica (pois, de acordo com a doutrina liberal, ela melhor funcionaria se as leis do mercado pudessem agir livremente), tampouco em se disciplinar a ordem social ${ }^{94}$.

Sob a influência da Constituição de Weimar de 1919, a Constituição Brasileira de 1934 inovou ao tratar, no seu Título IV, "da ordem econômica e social” e dispor, no seu artigo 115, que a "ordem econômica deve ser organizada conforme os princípios da Justiça e as necessidades da vida nacional, de modo que possibilite a todos existência digna. Dentro desses limites, é garantida a liberdade econômica”. Como se nota desse postulado, a essência individualista-liberal se manteve intacta, mas não há como desprezar a nova preocupação de proteção dos interesses coletivos, inexistentes nos diplomas que a precederam. As Constituições posteriores a 1934 continuaram a tratar da ordem econômica ${ }^{95}$.

EROS ROBERTO GRAU descreve a ordem econômica como sendo "o conjunto de normas que define, institucionalmente, um determinado modo de produção econômica" e chama a atenção para a proximidade dos conceitos de ordem econômica e Constituição Econômica. Esta última, para o autor, compreende o "conjunto de preceitos que institui determinada ordem econômica (mundo do ser) ou conjunto de princípios e regras essenciais ordenadoras da economia" ${ }^{96}$.

\footnotetext{
${ }^{94}$ Como demonstra AlBerTo VenÂNCIO FILHO, a Constituição Imperial de 1824 garante, sem embargo, o direito de propriedade e a livre iniciativa, e atribui-se aos representantes a atribuição de promover o bem geral da nação (ob. cit., pp. 42-43).

${ }^{95}$ A Constituição de 1937 enalteceu a liberdade de iniciativa ao dispor que "[n]a iniciativa individual, no poder de criação, de organização e de invenção do indivíduo, exercido nos limites do bem público, funda-se a riqueza e a prosperidade nacional" (artigo 135). A intervenção do Estado no domínio econômico só seria legítima para suprir as deficiências da iniciativa individual e coordenar os fatores da produção, "de maneira a evitar ou resolver os seus conflitos e introduzir no jogo das competições individuais o pensamento dos interesses da Nação, representados pelo Estado". A Constituição de 1946 tratou, no Título V, da "ordem econômica e social". Nos termos do artigo 145 e no seu parágrafo único, a ordem econômica deveria ser organizada conforme os princípios da justiça social, conciliando a liberdade de iniciativa com a valorização do trabalho humano, sendo assegurado a todos trabalho que possibilitasse existência digna. A Constituição de 1976 também trouxe um título dedicado à "ordem econômica e sócia" (Título III), o qual previa que a ordem econômica tinha por fim realizar a justiça social, com base nos princípios da liberdade de iniciativa, da valorização do trabalho como condição da dignidade humana, da função social da propriedade, da harmonia e solidariedade entre os fatores de produção, do desenvolvimento econômico e da repressão ao abuso do poder econômico, caracterizado pelo domínio dos mercados, a eliminação da concorrência e o aumento arbitrário dos lucros (artigo 157). Trataremos da ordem econômica na Constituição de 1988 na Seção 9 ("Os fins da política pública na Constituição de 1988”) e subseções.

${ }^{96}$ A Ordem Econômica na Constituição de 1988 (interpretação e crítica), pp. 72 e 81 . O autor observa que a expressão "ordem econômica" é usada em três diferentes conotações. Em primeiro lugar, "ordem econômica"
} 
A previsão de dispositivos a tratar da ordem econômica não chega a ser uma novidade, pois mesmo as Constituições liberais do século XVIII traziam, de certa forma, regras de repercussão econômica, ainda que de forma assistemática ou inconsciente ${ }^{97}$. É bem verdade que, em consonância com os dogmas do liberalismo, o que se procurava era garantir os fundamentos básicos do sistema (principalmente a liberdade de contratar e o direito de propriedade), de forma a permitir que a economia seguisse o seu caminho "natural"

GILBERTO BERCOVICI relata que o que caracteriza a Constituição Econômica surgida a partir do início do século XX é o fato de que ela não aceita mais a realidade econômica como ela se apresenta, mas propõe sua alteração, através do estabelecimento de objetivos e diretrizes que vinculam a atuação dos agentes públicos. Não se limita, assim, a disciplinar a realidade econômica de forma a garantir a manutenção do sistema, mas estabelece as bases para uma efetiva mudança social ${ }^{99}$.

À sociedade não basta mais que o Estado corrija as falhas e distorções do mercado. O Estado, ao atuar sobre e no processo econômico, deve, além disso, agir de forma racional e direcionada visando atingir os objetivos que a sociedade fixar como primordiais $^{100}$.

A previsão de uma ordem econômica nasceu como uma oposição a uma ordem social, parecendo indicar que o econômico e o social pertencem a duas realidades distintas. Essa bipartição traz uma alta carga ideológica, ao passar a mensagem de que a vida econômica teria se socializado ou humanizado, quando em verdade a ordem econômica, como parcela da ordem jurídica, sempre foi social, na medida em que seu

seria o "modo de ser empírico de uma determinada economia concreta", que exprime uma relação entre fenômenos e relações econômicos concretos. Nessa acepção, é, portanto, conceito de fato, pertencente ao mundo do ser. Em uma segunda acepção, "ordem econômica" designa o conjunto de normas de qualquer natura (e não somente jurídicas) que regulam o comportamento dos agentes econômicos. Por fim, "ordem econômica" seria a ordem jurídica da economia (pp. 66-67). Nesse terceiro significado, portanto, a "ordem econômica", como a Constituição Econômica, referir-se-iam a parcelas da ordem jurídica a regular a vida econômica.

${ }^{97}$ MANOEl GonÇAlves FerReira Filho, Direito Constitucional Econômico, pp. 3-4.

98 GILBerto BerCOVICI, Constituição Econômica e Desenvolvimento: uma leitura a partir da Constituição de 1988, pp. 31-33. EROS ROBERTO GRAU observa que o novo modelo da Constituição Econômica não trouxe, de fato, uma ruptura, uma vez que a "nova ordem" continuava comprometida com a anterior ( $A$ Ordem Econômica na Constituição de 1988 (interpretação e crítica), pp. 74-76).

${ }^{99}$ Constituição Econômica e Desenvolvimento. Uma Leitura a partir da Constituição de 1988, pp. 33-37.

${ }^{100}$ FÁbio Nusdeo, Curso de Economia. Introdução ao Direito Econômico, p. 168. AlBerto VENÂNCIO FILHO explica que a "predominância de normas programáticas, exprimindo definições, proposições gerais, recomendações, orientações e critérios de doutrina é uma das principais características dos capítulos sobre a ordem econômica e social nas constituições contemporâneas" (ob. cit., p. 51). 
nascimento e desenvolvimento se dão no seio da sociedade humana, e quando se constata que as mudanças empreendidas pelas Constituições Econômicas tiveram, em última análise, o propósito de garantir a própria sobrevivência do sistema já existente ${ }^{101}$.

Se, por um lado, não se pode negar o conteúdo ideológico presente nas Constituições Econômicas, por outro se deve reconhecer que elas trazem uma efetiva potencialidade de transformação ao indicar as metas e objetivos a serem seguidos pelo Estado, de forma a buscar a transformação do Estado liberal em um Estado social ${ }^{102}$.

"O direito é afetado, então, por uma transformação, justamente em razão de instrumentar transformação da ordem econômica (mundo do ser)" ${ }^{103}$. Esse conteúdo de transformação é determinado por duas circunstâncias: o fato de a nova ordem econômica compreender não apenas normas de ordem pública, mas normas de intervenção, que instrumentam a intervenção do Estado na economia, e o fato de a nova ordem estar integrada a uma Constituição dirigente, diretiva ou programática.

Enquanto as Constituições estatutárias ou orgânicas limitam-se a definir um estatuto do poder, e apenas recebem e afirmam a ordem jurídica praticada no mundo real, as Constituições programáticas enunciam os programas e fins a serem perseguidos pelo Estado e pela sociedade ${ }^{104}$. “A Constituição Econômica que nelas [Constituições programáticas] se encerra compreende a enunciação dos fins de política econômica, postulando, na sua conformação, a implantação de uma nova ordem econômica"105.

Essa potencialidade de transformação contida nas Constituições Econômicas torna-se possível de ser implementada, no mundo concreto, mediante a adoção, pelo Estado, de políticas públicas. Ao tratarmos das políticas públicas, no Capítulo que segue,

\footnotetext{
${ }^{101}$ Eros Roberto GRAU, A Ordem Econômica na Constituição de 1988 (interpretação e crítica), p. 71.

${ }^{102}$ De acordo com FÁbIo Konder COMPARATO, o Estado Social é "aquela espécie de Estado Dirigente em que os Poderes Públicos não se contentam em produzir leis ou normas gerais, mas guiam efetivamente a coletividade para o alcance de metas predeterminadas" (Ensaio sobre o Juízo de Constitucionalidade de Políticas Públicas, pp. 55-56).

${ }^{103}$ Eros Roberto GraU, A Ordem Econômica na Constituição de 1988 (interpretação e crítica), pp. 74-76. Observe-se, contudo, que a ordem econômica, como "o conjunto de normas que define, institucionalmente, um determinado modo de produção econômica", não é composta apenas de norma formalmente constitucionais, mas compreende diversas normas infraconstitucionais que tenham o mesmo escopo.

${ }^{104}$ J.J. GoMes CANOTILHO, ao tratar da Constituição Portuguesa de 1976, classifica-a como programática, pois contém numerosas normas-tarefas e normas-fim "definidoras de programas de acção e de linhas de orientação dirigidas ao Estado. Trata-se, pois, de uma lei fundamental não reduzida a um simples instrumento de governo, ou seja, um texto constitucional limitado à individualização dos órgãos e à definição de competências e procedimentos da acção dos poderes públicos. A ideia de "programa" associava-se ao carácter dirigente da Constituição" (Direito Constitucional e Teoria da Constituição, p. 217).

${ }^{105}$ EROS RoBerto GRAU, A Ordem Econômica na Constituição de 1988 (interpretação e crítica), pp. 77-78.
} 
ver-se-á que elas identificam-se com os programas contemplados nas Constituições programáticas, com o objetivo de implementação de determinados fins eleitos como prioritários na ordem jurídica. É por meio das políticas públicas adotadas pelo Estado que o caráter transformador das Constituições programáticas ganha possibilidade de concretude $^{106}$.

Deve-se observar, contudo, que a Constituição Dirigente não substitui as decisões políticas. $\mathrm{O}$ que se prevê são fundamentos constitucionais a serem observados e fins a serem buscados pelo Estado. Ao Poder Público compete a definição dos meios e instrumentos para a consecução dos fins constitucionais ${ }^{107}$, sem prejuízo da verificação da legalidade desses meios e instrumentos.

Na segunda metade do século XX, o papel do Estado passou a ser questionado. A doutrina neoliberal propõe uma diminuição cada vez maior da participação do Estado no processo econômico.

"O Estado é transformado no grande vilão e a receita passada é a seguinte: (i) desregulamentação dos mercados domésticos e eliminação das barreiras à entrada e saída de capital-dinheiro, de modo que a taxa de juros possa exprimir, sem distorções, a oferta e demanda de 'poupança' nos espaços integrados da finança mundial; (ii) para os mercados de bens, submissão das empresas à concorrência global, eliminando-se os resquícios do protecionismo e de quaisquer políticas deliberadas de fomento; (iii) para os mercados de trabalho, flexibilização e remoção das cláusulas sociais" 108 .

No que se refere à disciplina das operações cambiais, a ideologia neoliberal se traduz na defesa de uma total ou quase total ausência de controle dos fluxos de capitais por parte da autoridade monetária, o que significa, de um lado, a total liberdade de remessas do e para o País, e, do outro, a livre flutuação da taxa de câmbio de acordo com as "forças do mercado", as quais seriam capazes de, por si só, garantir o resultado mais eficiente para a sociedade. Como se verá na Seção 11 deste estudo (“A desregulamentação

\footnotetext{
${ }^{106}$ Essa transformação não implica uma revolução ou a substituição do modo de produção capitalista por qualquer outro; ao contrário, visa minimizar as assimetrias do sistema para garantir a sua reprodução e preservação.

${ }^{107}$ GILBERTO BerCOVICI, Constituição Econômica e Desenvolvimento: uma leitura a partir da Constituição de 1988, pp. 58-59.

${ }^{108}$ Eros Roberto GraU, A Ordem Econômica na Constituição de 1988 (interpretação e crítica), pp. 52-53.
} 
cambial"), o processo de "flexibilização" das normas cambiais levado a cabo no Brasil nas últimas décadas vem ao encontro dos anseios dos neoliberais.

O que se deve questionar é em que medida a omissão do Estado é capaz de proporcionar a consecução dos objetivos sociais eleitos na ordem jurídica e, mais ainda, até que ponto a ordem jurídica vigente autoriza essa omissão. De fato, não parece que o objetivo de bem-estar contemplado na Constituição de 1988 seja factível sem uma efetiva participação do Estado nessa direção. A análise histórica nos mostra que o atual sistema necessita da atuação do Estado não só para sua existência, mas para garantir a sua transformação.

\section{Nas palavras de FÁBIO KONDER COMPARATO:}

"a verdade é que a orientação finalística da ação governamental, em que pesem as proclamações ideológicas dos defensores do mercado livre, existe até mesmo nos Estados mais fundamentalmente marcados pelo neoliberalismo triunfante. Basta lembrar que é hoje unânime o reconhecimento, entre os economistas liberais, de que toda política econômica estatal deve orientar-se para a realização das quatro metas constitutivas do chamado 'quadrilátero mágico': a estabilidade monetária, o equilíbrio cambial, o crescimento constante da produção nacional e o pleno emprego." 109

Nesse sentido, o princípio básico da economia de que os mercados geralmente são uma boa forma de organizar a atividade econômica é temperado por outro a afirmar que os governos podem melhorar os resultados dos mercados ${ }^{110}$.

Em uma economia de mercado, a alocação de recursos se dá por meio das decisões descentralizadas das pessoas e empresas ao interagir nos mercados de bens e serviços. Os preços se ajustam à oferta e à demanda por bens e serviços, promovendo a organização da atividade econômica de modo a conduzi-la para o maior bem-estar geral. $\mathrm{O}$ fracasso das economias socialistas, nas quais o planejamento da atividade econômica é realizado pelo governo central, é apontado, pelos defensores do livre mercado, como evidência da superioridade da economia de mercado.

\footnotetext{
${ }^{109}$ Ensaio sobre o Juízo de Constitucionalidade de Políticas Públicas, p. 55.

${ }^{110}$ N. GREGORY MANKIW, ob. cit., pp. 9-12.
} 
Reconhece-se, contudo, que, na prática, a presença do Estado é fundamental para garantir as instituições básicas da economia de mercado (principalmente, o direito de propriedade e, como seu corolário, a liberdade de contratar) e conter as chamadas "falhas de mercado", isto é, as situações em que o mercado é incapaz de promover a alocação de recursos mais eficiente e eqüitativa.

\section{Como leciona BRESSER-PEREIRA:}

"[A]través do mercado e com o uso do dinheiro, os produtores competem entre si, e dessa forma o mercado aloca recursos e determina a distribuição de renda. No papel de alocador de recursos, o mercado é um mecanismo maravilhoso só embora cheio de falhas, e depende da ação regulatória do Estado para poder ser efetivo. Como instrumento distribuidor de renda, é cego e injusto. Por isso, a ação deliberada da sociedade através do Estado está sempre presente na regulamentação do mercado, e na tentativa de correção das suas falhas"111.

\section{PolíticA ECONÔMICA.}

Contemporaneamente ao surgimento das Constituições Econômicas e o conseqüente aumento de funções atribuídas ao Estado, o Direito Econômico começou a ser estudado com o ramo ou método próprio do Direito ${ }^{112}$, destinado a instrumentalizar a política econômica do Estado. A atuação do Estado na vida econômica justificaria a própria existência do Direito Econômico como ramo autônomo do Direito ${ }^{113}$.

${ }^{111}$ O Sistema Econômico Brasileiro, p. 16. Além de falhar na distribuição de recursos entre os agentes, o mercado auto-regulável não é capaz, ainda, de garantir a proteção devida ao consumidor (LUíS ROBERTO BARroso, A Ordem Econômica Constitucional e os Limites à Atuação Estatal no Controle de Preços, p. 10).

${ }^{112}$ Fugiria do objeto do nosso estudo discutir se o Direito Econômico constitui ou não um ramo autônomo do Direito. Tendo em mente que as classificações têm por objetivo apenas simplificar a compreensão da realidade, que é única, essa discussão não parece ajudar na nossa análise. Cabe, contudo, notar que a Constituição Econômica de 1988 parece reconhecer a autonomia do Direito Econômico ao prever, no inciso I do seu artigo 24, a competência concorrente da União, dos Estados e do Distrito Federal para legislar sobre direito econômico.

113 FÁbIo Konder Comparato, O Indispensável Direito Econômico, p. 465; Washington PELUSO AlbinO DE SOUZA, Teoria da Constituição Econômica, p. 223; EROS RoBERTO GRAU, A Ordem Econômica na Constituição de 1988 (interpretação e crítica), pp. 154-155; ANDRÉA QUEIROZ FABRI, Política Econômica e Desenvolvimento, p. 10. É interessante notar que ANDRÉ DE LAUBADÈRE define o direito público econômico como "o direito aplicável às intervenções das pessoas públicas na economia e aos órgãos dessas intervenções" (Direito Público Económico, p. 28). 
A política econômica identifica-se com a própria atuação do Estado na e sobre a atividade econômica em sentido amplo. Deve ser conformada pelo ordenamento jurídico ao mesmo tempo em que se utiliza do ordenamento jurídico como instrumento para sua implementação.

Uma vez adotado e aceito um modo de produção como realidade, cabe ao Estado adotar medidas que visam operacionalizar a vida econômica de acordo com as premissas fundamentais desse sistema, e atuar de forma tal que as modificações eventualmente realizadas tenham por objetivo a sua evolução, de acordo com os parâmetros fixados pela sociedade, observando-se as linhas mestras que o caracterizaram. Ao agir dessa forma, o Estado exerce a política econômica.

Nesse sentido, BERNARD CHENOT define a política econômica de um governo como sendo o conjunto de atos através dos quais o poder exerce influência sobre a vida econômica ${ }^{114}$ e destaca que todo governo, simplesmente pelo fato de existir, tem uma política econômica, ainda que carente de coerência e sistematização.

FÁBIO NUSDEO trata a política econômica como o "estudo das relações entre certas variáveis sob a ótica de que umas serão meios ou instrumentos para que outras assumam um determinado valor ou posição". Dessa forma, a política econômica busca "viabilizar os objetivos tidos como necessários ou desejáveis pela comunidade, servindo-se dos instrumentos que o próprio sistema coloca a seu dispor" $" 115$.

GIOVANi ClaRK, por sua vez, define a política econômica como sendo as “ações coordenadas, ditadas por normas jurídicas, onde os órgãos públicos atuam na vida econômica presente e futura, e automaticamente nas relações sociais, em busca, hipoteticamente, da efetivação dos comandos da Constituição Econômica. Em síntese, política econômica estatal é um conjunto de decisões públicas dirigidas a satisfazer as necessidades sociais e individuais, com um menor esforço, diante de um quadro de carência de meios"116.

\footnotetext{
114 "L'ensemble des actes par lesquels le Pouvoir exerce une influence sur la vie économique forme la politique économique du governement" [tradução livre: "O conjunto dos atos através dos quais o Poder exerce uma influência sobre a vida econômica forma a política econômica do Estado"] (Organisation Économique de L'État, p. 454).

${ }^{115}$ Curso de Economia. Introdução ao Direito Econômico, pp. 168-169.

${ }^{116}$ Ob. cit, p. 41.
} 
Ao se analisar as opiniões dos autores acima, percebe-se que a política econômica é tratada como o conjunto dos atos do Estado na e sobre a vida econômica, os quais encontram seu fundamento e devem ser conformados pela ordem jurídica. Mais precisamente, a política econômica tem como objetivo último a viabilização dos objetivos definidos pela ordem.

Por outro lado, o ordenamento jurídico serve como instrumento de política econômica, na medida em que é através das regras jurídicas que o Estado impõe aos agentes a compulsoriedade de adoção de determinadas condutas desejáveis ou necessárias para a consecução de uma determinada política, proíbe a prática de outras condutas que possam ser prejudiciais ou cria incentivos para que os agentes ajam da forma almejada.

Ao tratarmos da relação entre política econômica e o ordenamento jurídico, não há como afastar esse duplo nível de influência: ao mesmo tempo em que o ordenamento serve como instrumento de implementação da política econômica, a política econômica encontra seu fundamento e a definição dos seus objetivos no ordenamento jurídico.

Os atos de política econômica do Estado são comumente organizados sob diversas temáticas distintas, dependendo do foco de atuação do Estado no caso concreto e dos instrumentos manejados nessa atuação. A política monetária, por exemplo, engloba a atuação do Estado (através, principalmente, do CMN e do BACEN) para definir as condições de liquidez da economia (quantidade ofertada de moeda, nível da taxa de juros, entre outros) ${ }^{117}$.

Referimo-nos especificamente à política cambial como um dos instrumentos da política econômica, através do qual o Estado atua de forma a administrar a taxa de câmbio e controlar a reserva de divisas do País. Nesse sentido, a política econômica seria gênero do qual a política cambial é espécie.

FÁBIO NUSDEO explica que, no exercício da política econômica, cabe garantir maior especificidade aos fins estipulados para o sistema econômico. Nesse processo, os fins determinados pela comunidade, normalmente genéricos e vagos, são traduzidos em objetivos, conceitos mais operacionais e técnicos, para, por fim, serem

117 Amaury Patrick Gremauld, Marco Antonio Sandoval de Vasconcellos e Rudinei Toneto JÚNIOR, ob. cit., p. 220. 
transformados, quando possível, em metas, mediante a atribuição de um valor quantitativo aos objetivos.

Não há como escapar do caráter pragmático e instrumental da política econômica. A tarefa do Estado é realizar, na prática, os fins eleitos como prioritários pela sociedade, e não de tratar da política econômica como se fosse um fim em si mesmo. Além disso, ao indicar os meios necessários para atingi-los, deve garantir que esses meios estejam de acordo com os próprios fins previstos na ordem. Deve haver um permanente controle social sobre o processo de formulação e aplicação da política econômica para evitar que esse processo assuma feições totalitárias ${ }^{118}$.

\section{AS FORMAS DE ATUAÇÃO DO ESTADO NO E SOBRE O PROCESSO} ECONÔMICO.

A partir da constatação de que a política econômica identifica-se com a própria atuação do Estado na e sobre a economia, algumas considerações devem ser feitas sobre a forma como se dá essa atuação.

De acordo com a classificação proposta por EROS ROBERTO GRAU, que, como destaca o próprio autor, tem o mérito de considerar o caráter jurídico distinto de cada uma das técnicas, a expressão "atividade econômica", em sentido amplo, engloba o serviço público e a atividade econômica em sentido estrito ${ }^{119}$. O serviço público se caracteriza por abarcar aquelas atividades fundamentais à coesão e à interdependência social, de acordo com os critérios e princípios determinados pela Constituição Federal. Em virtude do seu caráter de essencialidade para com a ordem vigente, devem ser prestados, de forma privativa ou não, pelo Estado.

\footnotetext{
${ }^{118}$ FÁBIo NuSDEO, Curso de Economia. Introdução ao Direito Econômico, p. 170.

119 Eros Roberto GraU, A Ordem Econômica na Constituição de 1988 (interpretação e crítica), pp. 92155, e $O$ Direito Posto e o Direito Pressuposto, p. 27. A classificação dos tipos de intervenção do Estado no e sobre o processo econômico, desenvolvida nessa seção, tomou como base a doutrina de EROS ROBERTO GRAU. Além dos serviços públicos e das atividades econômicas em sentido estrito, incluem-se no conceito de atividades econômica em sentido amplo as atividades ilícitas. Para os fins deste trabalho, tomaremos a liberdade de ignorá-las, já que seu estudo não influencia de forma determinante as nossas conclusões.
} 
Por outro lado, as atividades econômicas em sentido estrito são aquelas que não são reconhecidas pela ordem jurídica como serviço público (isto é, que não são essenciais à coesão e à interdependência social) e que integram o universo do privado. A atuação do Estado no espaço dos particulares pode ser referida como intervenção, na medida em que denota uma atuação na esfera de outrem ${ }^{120}$.

O Estado, ao intervir na atividade econômica em sentido estrito, atua como agente ou sujeito econômico (e, nesse caso, intervém no domínio econômico) ou como regulador (atuando, então, sobre o domínio econômico).

Ao intervir no domínio econômico, o Estado empresário age por absorção, quando atua em regime de monopólio e assume integralmente o controle dos meios de produção e/ou troca de um determinado setor, ou por participação, quando assume parte desse controle e concorre com as demais empresas privadas que desenvolvem suas atividades no mesmo setor.

Já quando intervém sobre o domínio econômico, o Estado pode tanto agir por direção, ao estabelecer regras e mecanismos de comportamento compulsório para os agentes econômicos, ou por indução, ao criar incentivos e estímulos (ou desestímulos) para os agentes econômicos, com base nas leis que regem os mercados.

As normas de intervenção por direção são comandos cogentes, direcionadas aos agentes que atuam nas atividades econômicas em sentido estrito, e por eles devem ser cumpridas. Já as normas de intervenção por indução são normas dispositivas, que, ao contrário de prever uma sanção para uma determinada conduta ou omissão, prescrevem um incentivo aos agentes econômicos para que adotem determinada conduta que terá um efeito positivo para toda a coletividade. Os agentes podem, nesse caso, optar por não agir de acordo com as normas de intervenção por indução sem que haja a aplicação de sanções.

No exercício da política cambial, o Estado ora intervém sobre o domínio econômico, ora intervém no domínio econômico. Intervém sobre o domínio econômico quando regula os contratos de câmbio, limitando a possibilidade de contratação com instituição autorizada a atuar no mercado de câmbio pelo BACEN e determinando o

\footnotetext{
${ }^{120}$ Ou seja, na classificação utilizada por EROS ROBERTO GRAU, a expressão "atuação do Estado" é utilizada para referir a atividade econômica do Estado em sentido amplo (incluindo a prestação do serviço público e a intervenção na atividade econômica em sentido estrito ou domínio econômico).
} 
conteúdo dos contratos. É nesse contexto que são emanadas as regras do CMN e do BACEN, no exercício da capacidade normativa de conjuntura, para regular o câmbio.

O Estado age, por outro lado, no domínio econômico quando comparece no mercado de câmbio comprando ou vendendo moeda estrangeira ou títulos indexados a moeda estrangeira, como qualquer outro agente econômico, ou quando celebra operações de swap cambial e, dessa forma, influencia a formação da taxa de câmbio ${ }^{121}$.

Quando age sobre o domínio econômico, o Poder Executivo exerce verdadeira função normativa ou regulamentar, a qual EROS ROBERTO GRAU denomina capacidade normativa de conjuntura ${ }^{122}$.

Na clássica separação de poderes, ao Poder Legislativo compete o poderdever de introduzir, dentro do sistema jurídico vigente, novas regras. Ao Executivo restam as funções meramente executivas. Em realidade, a vida econômica apresenta circunstâncias de natureza conjuntural que exigem, da Administração Pública, atuação imediata no sentido de corrigir eventuais distorções ou redirecionar o curso de algum programa de ação. A atuação estatal que a realidade demanda para que não haja interrupção da fluência das relações econômicas, nesses casos, é incompatível com o processo legislativo. É nesse cenário que a capacidade normativa de conjuntura se manifesta, como "dever-poder, de órgãos e entidades da Administração, que envolve, entre outros aspectos, a definição de condições operacionais e negociais, em determinados setores dos mercados"123.

${ }^{121}$ ANDRÉ DE LAUBADÈRE menciona algumas outras formas de classificar a atuação do Estado na economia, a saber: (i) tendo em conta o seu alcance, as atuações podem ser globais, setoriais ou pontuais; (ii) podem ser diretas ou indiretas, dependendo se são direcionadas aos agentes econômicos diretamente ou não; (iii) podem, ainda, as intervenções ocorrer por via unilateral, quando são operacionalizadas por meio de atos promulgados unilateralmente pelo Poder Público, ou por via convencional, quando decorrem de contratos firmados pelo Poder Público; e, por fim, (iv) podem as intervenções relacionar-se às empresas privadas (que parece se identificar com a atuação do Estado sobre o processo econômico, na classificação de EROS GRAU) ou relativas ao setor público econômico (que se identifica com a atuação do Estado no processo econômico). LAUBADÈRE reconhece que essa última classificação - que se identifica com aquela de EROS GRAU sobre a qual discorremos - é a mais importante delas (ob. cit., pp. 28-31). Na doutrina nacional, podemos citar classificação adotada por LUís ROBERTO BARROSO, que identifica três modalidades de atuação do Estado na economia. São elas a atuação direta, o fomento e a disciplina. $\mathrm{Na}$ atuação direta, o Estado assume o papel do empresário ao prestar um serviço público ou explorar atividades econômicas (em sentido estrito). O Estado atua por via de fomento, quando estimula determinados comportamentos dos agentes econômicos privados, por meio de normas diretivas. Na atuação estatal de disciplina, o Poder Público atua como agente normativo e regulador (ob. cit., pp. 17-19).

122 O Direito Posto e o Direito Pressuposto, pp. 230-233.

${ }^{123}$ O Direito Posto e o Direito Pressuposto, p. 232. Como expõe Eros RoBerto GraU, de forma clara, "a instabilidade de determinadas situações e estados econômicos, sujeitos a permanentes flutuações - flutuações que definem o seu caráter conjuntural -, impõe sejam extremamente flexíveis e dinâmicos os instrumentos normativos de que deve lançar mão o Estado para dar correção a desvios ocorridos no desenrolar do processo econômico e no curso das políticas públicas que esteja a implementar". 
Como adverte EROS ROBERTO GRAU, a capacidade normativa de conjuntura não chega a negar a separação de poderes de Montesquieu, na medida em que essa não exige uma completa separação, mas uma distinção entre os poderes, os quais devem, entretanto, ser exercidos em equilíbrio. O que caracteriza a função executiva é a necessidade de atuação sobre situações momentâneas, ao passo que a função legislativa se exerce sobre situações de ordem estrutural. Na medida em que, como visto, a capacidade normativa de conjuntura justifica-se justamente para atendimento de circunstâncias de ordem conjuntural, há plena compatibilidade entre a separação de poderes e a capacidade normativa de conjuntura.

De fato, não se pode confundir a capacidade normativa de conjuntura com o exercício de função legislativa ${ }^{124}$. O poder estatal (assim considerado como o poder político juridicamente organizado) traduz-se na concentração de funções estatais, sendo que se entende “(...) por função estatal a expressão do poder estatal, enquanto preordenado às finalidades de interesse coletivo e objeto de um dever jurídico - tomada a expressão poder estatal, então, no seu aspecto material" ${ }^{\prime 25}$.

Classificadas de uma perspectiva material, as funções estatais podem ser divididas em função normativa, que abarca produção das normas jurídicas, a função administrativa, que contempla a execução das normas jurídicas, e a função jurisdicional, que implica a aplicação das normas jurídicas.

A função normativa não se confunde com a função legislativa, mas a engloba. É compreendida pela função legislativa, pela função regulamentar (lugar onde a capacidade normativa de conjuntura se expressa) e pela função regimental (correspondente à normatividade emanada do Poder Judiciário).

A capacidade normativa de conjuntura, expressão da função regulamentar e parcela da função normativa, deve ser exercida de acordo com os fundamentos e objetivos fixados na ordem constitucional, e dentro dos limites e autorizações previstos na lei. Mais, o próprio fundamento da capacidade normativa de conjuntura está na lei.

Na prática, vemos uma tendência do Poder Judiciário, ao apreciar questões relacionadas ao exercício da capacidade normativa de conjuntura ou outros atos de

\footnotetext{
${ }^{124}$ Eros Roberto GraU, O Direito Posto e o Direito Pressuposto, pp. 236-244.

${ }^{125}$ Eros Roberto Grau, O Direito Posto e o Direito Pressuposto, p. 237.
} 
intervenção do Poder Público do domínio econômico, especialmente no que se refere à implementação de políticas econômicas, a resumir sua apreciação a uma análise sobre a compatibilidade das medidas com a ordem de um ponto de vista fundamentalmente formal. Isto é, na maior parte das vezes, o Judiciário limita-se a apreciar se a autoridade que emitiu determinado ato teria atribuição ou competência formal para fazê-lo. No mérito, as questões são usualmente referenciadas a um juízo discricionário da Administração, o qual escaparia do controle do Poder Judiciário ${ }^{126}$.

Maria Sylvia Zanella Di Pietro entende que "existe discricionariedade quando a lei deixa à Administração a possibilidade de, no caso concreto, escolher entre duas ou mais alternativas, todas válidas perante o direito. E essa escolha se faz segundo critérios de oportunidade, conveniência, justiça, eqüidade, razoabilidade, interesse público, sintetizados no que se convencionou chamar de mérito do ato administrativo" ${ }^{127}$.

EROS ROBERTO GRAU ${ }^{128}$ afirma que a doutrina brasileira confunde a atividade discricionária da Administração com a interpretação do direito. A atividade de

\footnotetext{
126 Alguns exemplos podem ser encontrados. Em mandado de segurança julgado em 1954, o Supremo Tribunal Federal (STF) apreciou caso em que o Presidente da República havia recusado conceder licença de importação a empresa que pretendia importar farinha de trigo e vendê-la, no País, com redução de até $25 \%$ do preço na tabela oficial. Em sua manifestação, a empresa alegou que a legislação em vigor à época autorizava o governo a intervir no domínio econômico para garantir a livre distribuição de mercadorias e serviços essenciais, mas não com o intuito apenas de encarecer o preço das mercadorias no interesse exclusivo do "trust" moageiro. O Ministro das Relações Exteriores manifestou-se no sentido de que "não obstante a desclassificação da proposta por efeito da preliminar [proibição de importação de farinha de trigo por empresas particulares], foi considerado o mérito da mesma que, sob o ponto de vista cambial, é prejudicial aos interesses nacionais, ante a notória escassez da moeda pretendida para realizar a operação. Por outro lado, dado o superávit na produção mundial de trigo, o Brasil está em condições de comprar o cereal em melhores condições de pagamento em outros centros fornecedores". Conclui que a importação seria contra os interesses nacionais, haja vista que a prioridade era a importação do grão de trigo para que fosse processado no Brasil, com a utilização do parque industrial já instalado e a utilização dos subprodutos na forragem do gado. O STF decidiu então, por unanimidade, denegar a segurança. Em seu voto, o relator, Ministro Nelson Hungria, justificou que "não vejo em que seja ilegal o ato do Sr. Presidente da República, posto que nós não podemos entrar na indagação do acerto ou desacerto dessa medida do ponto de vista econômico, dado que não estamos aqui para corrigir a política econômica do Governo" (Mandado de Segurança no 2.310 - Distrito Federal, Pleno, rel. o Ministro Nelson Hungria, j. 12.07.1954). Em caso mais recente, que tratou sobre a liberação dos preços da cana-de-açúcar por ato do Ministro da Fazenda, a Primeira Turma do STF entendeu que, verificada a competência daquela autoridade para realizar a liberação dos preços, conforme a legislação vigente, não competia ao Judiciário apreciar o mérito dessa decisão. A ementa do respectivo acórdão diz: “(...). O art. 10 da Lei $\mathrm{n}^{\circ}$ 4.870/65, que previa a fixação do preço da cana-de-açúcar, foi alterado pelo art. $3^{\circ}$, III, da Lei n ${ }^{\circ}$ 8.178/91, que deixou a critério do Ministro da Fazenda, responsável pela execução da política econômica do Governo, a liberação, total ou parcial, dos preços de qualquer setor, o que foi concretizado pela referida autoridade por meio do ato impugnado, em face do manifesto descabimento da exigência de lei, ou de decreto, para fixação ou liberação de preços. (...) No que concerne ao mérito do ato impugnado, é fora de dúvida que se trata de matéria submetida a critérios de conveniência e oportunidade, insuscetíveis, por isso, de controle pelo Poder Judiciário. Recurso desprovido." (Recurso em Mandado de Segurança no 23.543-1 DF, $1^{\text {a }}$ Turma, r. o Ministro Ilmar Galvão, j. 27.06.2000).

${ }^{127}$ Discricionariedade Técnica e Discricionariedade Administrativa, p. 2.

${ }^{128}$ O direito posto e o direito pressuposto, pp. 191-224.
} 
interpretação pressupõe a escolha, pelo intérprete, de uma solução adequada entre várias possíveis.

A discricionariedade, por outro lado, se expressa na formulação de juízos de oportunidade, importando eleição entre indiferentes jurídicos. No Estado de Direito, qualquer agente público somente terá competência para a prática de atos discricionários quando norma jurídica válida a ele atribuir a formulação de juízos de oportunidade, e não da circunstância de serem ambíguos ou equívocos (caso em que se faz necessária a atividade de interpretação).

O exercício da autêntica discricionariedade não está sujeita ao controle do Poder Judiciário, salvo quando consubstancie desvio ou abuso de poder ou de finalidade. Acrescenta o autor que, considerando que a Administração está obrigada a motivar seus atos, o Poder Judiciário controla o ato a partir da análise e ponderação da motivação. Observa, ainda, que atos motivados por razões de interesse público não são atos discricionários. "Interesse público" é noção que exige interpretação adequada, em cada caso concreto, entre várias interpretações possíveis.

SEABRA FAGUNDES entende que há discricionariedade nos casos em que a lei deixa a autoridade administrativa livre na apreciação do motivo ou do objeto do ato, ou de ambos ao mesmo tempo. No que refere ao motivo, a discrição se refere à ocasião de praticar o ato (oportunidade) e à utilidade (conveniência). Já no que se refere ao conteúdo, a discrição está em poder praticar o ato com objetivo variável, ao seu entender. $\mathrm{O}$ autor acrescenta que não há, nessas hipóteses, quebra de submissão à ordem jurídica, mas apenas de uma submissão adstrita a limites diversos dos comuns, mas regulada e admita pelo direito. Essas limitações vinculam a competência discricionária à legalidade ${ }^{129}$.

EROS ROBERTO GRAU nega, ainda, a chamada "discricionariedade técnica", que consistiria naquelas decisões administrativas "que supõem tal grau de especialização técnica que somente aqueles que as toma, a partir da consideração de elementos altamente técnicos, as pode valorar" ${ }^{\prime 30}$.

A Administração Pública teria, nesses casos, ampla liberdade de atuação. O Poder Judiciário deveria acatar suas decisões, exceto em caso de erro manifesto. Na

\footnotetext{
${ }^{129}$ O controle dos atos administrativos pelo Poder Judiciário, pp.64-67; 82-84.
}

${ }^{130}$ O direito posto e o direito pressuposto, pp. 214-215. 
opinião de EROS GRAU, exatamente por se tratar de matéria técnica, deve haver standards de atuação altamente precisos. Além disso, é de difícil determinação o que se pode efetivamente considerar como sendo decisão técnica ou não. Se o juiz não conhece a matéria em questão, deve ouvir peritos que possam lhe trazer subsídios para a sua devida apreciação. Deve-se observar, ainda, que a liberdade para decisão de acordo com juízos de oportunidade e conveniência decorre de atribuição legal específica, e não da natureza da matéria. Por fim, não há como se afastar da dificuldade de determinação do que é um erro manifesto. $\mathrm{O}$ erro, ainda que não manifesto, deve ser corrigido.

\section{ATUAÇÃO DO ESTADO NO CÂMBIO.}

A taxa de câmbio é o preço da moeda estrangeira e reflete a relação entre a moeda nacional e a moeda estrangeira. É considerada um dos preços básicos da economia de mercado e exerce papel essencial na política econômica do Estado.

De ChiARA, ao tratar da taxa de câmbio, destaca, como tivemos a oportunidade de mencionar na Seção 2.3 deste trabalho ("Taxa de câmbio"), que a noção de equivalência que é inerente ao preço na compra e venda enfrenta limitações no que se refere à taxa de câmbio, em virtude dos diversos condicionamentos que influenciam a sua formação.

\section{Acrescenta o professor DE CHIARA:}

"[D]e fato ela é considerada um preço definido pelo Estado para negócios entre particulares que assegura a comunicação formal do sistema monetário do Estado com outras unidades monetárias. A administração da taxa de câmbio é solução jurídica de natureza instrumental exercida de acordo com os interesses prevalentes do Estado, implicando limitação à livre decisão dos agentes privados. Por isso representa superação da proposta liberal que não acolhia restrições diretas ou indiretas ao funcionamento dos mercados, sendo ainda tratadas como medidas de exceção nos Estados em que prevalece o liberalismo. Isto de certa forma explica a ausência de critérios definidos para a disciplina cambial em certos países, 
dificultando o entendimento dos objetivos colimados na utilização dos mecanismos das taxas de câmbio" $" 131$.

A taxa de câmbio e suas alterações podem afetar consideravelmente as economias dos países. "Juntamente às taxas de juros, a taxa de câmbio é a variável econômica de maior importância para a determinação dos agregados macroeconômicos (consumo, investimento, exportação e importação). Do ponto de vista microeconômico, a taxa de câmbio é determinante fundamental dos comportamentos dos consumidores e empresários",132.

Apesar de a administração da taxa de câmbio ser uma expressão de soberania de cada país, influencia de forma contundente as outras economias com as quais tenham relação direta ou indireta, através de parceiros comerciais. Sua relevância, portanto, extrapola os limites de cada Estado.

O mercado de câmbio brasileiro pode ser dividido em mercado primário e mercado secundário ou interbancário ${ }^{133}$. No mercado primário, são cursadas as operações entre, de um lado, os agentes que necessitam comprar divisas para realizar pagamentos no exterior (como, por exemplo, importadores ou devedores de empréstimos externos que precisam realizar os respectivos pagamentos) ou vender divisas recebidas do exterior (como exportadores ou tomadores de empréstimos externos) e, de outro lado, as instituições autorizadas a operar no mercado de câmbio pelo BACEN.

O mercado secundário de câmbio ou mercado interbancário é aquele no qual os bancos praticam entre si operações de compra e venda de moeda estrangeira, com os objetivos de realizar hedge, arbitragem ou especulação, bem como para nivelar suas posições cambiais $^{134}$.

\footnotetext{
${ }^{131}$ Ob. cit., pp. 155-156.

${ }^{132}$ Márcio G. P. Garcia e Fabio Urban, O Mercado Interbancário de Câmbio no Brasil, p. 5.

${ }^{133}$ Sobre a divisão do mercado de câmbio entre mercado primário e mercado secundário ou interbancário e a atuação dos agentes nesses mercados, consultamos especialmente MÁRCIO G. P. GARCIA e FABIO URBAN, ob. cit.

${ }^{134}$ As operações de hedge têm por finalidade eliminar ou reduzir o risco cambial decorrente de outras operações realizadas. Nas operações de arbitragem, os bancos procuram auferir ganhos com a diferença de preços ou taxas de juros (nesse sentido, procuram, por exemplo, ganhar com a diferença entre as taxas de câmbio praticadas no mercado secundário e aquelas oferecidas ao cliente no mercado primário). Quando realizam operações com a finalidade de especulação, os bancos procuram auferir ganhos ao tentar antecipar o comportamento futuro da taxa de câmbio.
} 
É importante observar que a demanda e a oferta de moeda estrangeira são originadas das operações com o exterior, normalmente cursadas no mercado primário. Em regra, as operações do mercado primário são refletidas no balanço de pagamentos e alteram o saldo das reservas internacionais do País, ao reduzir ou aumentar o volume de dólares em poder do mercado. Já as operações do mercado secundário não são refletidas no balanço de pagamentos, pois circulam apenas entre os bancos domésticos. Apesar de não influenciarem o balanço de pagamentos, as operações realizadas no mercado interbancário, assim como aquelas realizadas no mercado de derivativos e sobre as quais falaremos adiante, influenciam de forma relevante na formação da taxa de câmbio.

O BACEN participa do mercado interbancário de câmbio de duas formas. Em primeiro lugar, atua como liquidante, processando, monitorando e controlando os fluxos dos pagamentos em moeda nacional. Além disso, pratica operações de câmbio com o objetivo de cumprir suas atribuições previstas na Lei $n^{\circ} 4.595 / 1964^{135}$.

Além da compra e venda de moeda estrangeira no mercado interbancário (câmbio pronto), o BACEN pode intervir no mercado de câmbio através da celebração de operações de derivativos cambiais ou da negociação de títulos indexados ao dólar ${ }^{136}$.

As operações com derivativos cambiais merecem algumas considerações gerais, já que essas operações podem ocasionar efeito relevante sobre a cotação da moeda nacional sem que haja efetivamente qualquer operação envolvendo residentes e nãoresidentes. Nesse contexto, as decisões dos titulares de riqueza e de devedores sobre a moeda de denominação dos seus ativos são essenciais para a determinação da taxa de câmbio.

\footnotetext{
${ }^{135}$ Em suma, participam do mercado interbancário de câmbio os bancos, o BACEN, as corretoras de câmbio, os bancos correspondentes no exterior e a clearing (sistema de compensação e liquidação) de câmbio da BM\&FBOVESPA S.A. - Bolsa de Valores, Mercadorias e Futuros (BM\&FBOVESPA). As corretoras de câmbio participam como centros de negociação, de forma facultativa. Por regra, as corretoras não podem negociar operações por conta própria, exceto em situações especiais. Os bancos correspondentes no exterior atuam como liquidantes, operacionalizando a movimentação dos recursos financeiras de forma similar ao BACEN no que concerne a pagamentos em moeda nacional no Brasil. A clearing de câmbio da BM\&FBOVESPA garante a finalização das operações contratadas e reduzindo o risco de pagamento. De acordo com Circular BACEN n ${ }^{\circ} 3.083$, de 30 de janeiro de 2002, as operações de compra e de venda de moeda estrangeira pelo BACEN, no mercado interbancário, são realizadas exclusivamente com instituições credenciadas para esta finalidade (dealers), nas seguintes modalidades: (i) diretamente com instituições credenciadas; (i) pelo sistema informatizado - leilão eletrônico; (iii) pelo sistema de leilão telefônico; e (iv) através de negociação via plataforma eletrônica.

${ }^{136}$ GuSTAVO H. B. Franco, Crônicas da Convergência: ensaios sobre temas já não tão polêmicos, pp. 345348.
} 
Os derivativos são usualmente referidos como todo instrumento financeiro cujo valor deriva ou depende de uma variável mais básica, normalmente o preço de um bem ou uma taxa ou índice. Em termos gerais, os instrumentos derivativos são negócios jurídicos nos quais as partes pactuam um preço para um bem (ativo subjacente) em uma data futura e, naquela data, contrapõem este preço ao preço de mercado, normalmente transferindo apenas a diferença entre si (e não os ativos). Essas operações podem ser celebradas para proteção contra riscos (hedge) ou para simples especulação ${ }^{137}$.

Entre as operações de derivativos, podemos citar, como principais, os contratos a termo, os contratos futuros, os swaps e as opções. Os contratos a termo e os contratos futuros são operações de compra e venda de um determinado bem ou ativo financeiro, com execução diferida. O preço e os demais elementos do contrato são fixados na data de sua celebração.

No caso das operações envolvendo câmbio, as partes definem, no ato da contratação, a taxa de câmbio. A moeda estrangeira é o ativo subjacente. $\mathrm{Na}$ data de vencimento da operação, a liquidação se faz pela diferença de valores, em moeda nacional. Não há efetiva entrega de moeda estrangeira, mesmo porque essas operações são muitas vezes celebradas entre pessoas físicas e jurídicas não autorizadas a celebrar operações de câmbio pelo BACEN.

As operações de swap consistem em operações financeiras mediante as quais as partes trocam as diferenças entre as valorizações, sobre um determinado valor de referência, entre diferentes índices ou taxas previamente acordados, inclusive a variação cambial $^{138}$.

\footnotetext{
${ }^{137}$ OtAVio YAZBEK, Regulação do Mercado Financeiro e de Capitais, pp. 106-130. Como explicado pelo autor, os instrumentos derivativos desenvolveram-se, por muito tempo, sem que houvesse um regime próprio a eles aplicável. Começaram a ser utilizados no Brasil na antiga Bolsa de Mercadorias de São Paulo (BMSP), em 1918, com a negociação de negócios futuros de algodão. As operações tiveram maior impulso a partir de 1986, com a criação da Bolsa de Mercadorias e Futuros (ainda denominada Bolsa Mercantil e de Futuros). O Decreto-lei $\mathrm{n}^{\circ} 2.286$, de 23 de julho de 1986, estabeleceu a competência genérica do CMN para regulamentar os mercados a termo (artigo $2^{\circ}$ ). Por meio da Resolução $\mathrm{n}^{\circ} 1.190$, de 17 de setembro de 1986, o CMN determinou que os modelos dos contratos fossem submetidos previamente ao BACEN e à Comissão de Valores Mobiliários (no caso desta última, quando o objeto fosse referenciado a valor mobiliário). Após as alterações promovidas pela Lei $n^{\circ} 10.303$, de 31 de outubro de 2001, e pela Lei $\mathrm{n}^{\circ} 10.411$, de 26 de fevereiro de 2002, todos os mercados de derivativos foram formalmente colocados sob a competência da Comissão de Valores Mobiliários.

${ }^{138}$ A Resolução CMN no 2.873, de 26 de julho de 2001, define as operações de swap como "aquelas realizadas para liquidação em data futura que impliquem na (sic) troca de resultados financeiros decorrentes da aplicação, sobre valores ativos e passivos, de taxas ou índices utilizados como referenciais" (artigo $1^{\circ}$, parágrafo $1^{\circ}$ ). Essa Resolução faculta aos bancos múltiplos, aos bancos comerciais, à Caixa Econômica
} 
As opções são, nas palavras de OtAvio YAZBEK, "aquelas operações em que uma das partes (o "comprador" ou "titular") adquire, a título oneroso (pelo pagamento do prêmio), o direito de comprar da outra parte (o "vendedor" ou "lançador") ou de a ela vender um determinado ativo, em uma data futura, por um preço prefixado (o "preço de exercício" ou "strike")"139.

A Resolução CMN n 2.939, de 26 de março de 2002, autoriza o BACEN a realizar, para fins de políticas monetária e cambial, operações de swap referenciadas em taxas de juros e variação cambial (artigo $1^{\circ}$ ). De fato, o BACEN tem realizado leilões públicos para a celebração de operações de swap, inclusive com o objetivo de rolagem das operações vencidas $^{140}$. As operações são realizadas na BM\&FBOVESPA S.A. - Bolsa de Valores, Mercadorias e Futuros, podendo participar das ofertas instituições financeiras, bem como pessoas físicas e demais pessoas jurídicas por intermédio de instituições financeiras.

Dependo da posição que a autoridade monetária assume nas operações de swap, proporciona ao mercado a variação da taxa de câmbio ou da taxa de juros. Nas chamadas operações de swap cambial reverso, o BACEN dá aos participantes da oferta a variação da taxa de juros e recebe, em contrapartida, a variação do dólar. Ficando ativo no swap cambial, o BACEN assume para si o risco de variação do dólar e paga ao mercado a oscilação da taxa de juros.

Como explica Gustavo H. B. Franco, ao tratar sobre a influência das operações de swap na formação da taxa de câmbio:

Federal, aos bancos de investimento, às sociedades corretoras de títulos e valores mobiliários e às sociedades distribuidoras de títulos e valores mobiliários a realização, no mercado de balcão, por conta própria ou de terceiros, de operações de swap, a termo e com opções não padronizadas, referenciadas em ouro, taxas de câmbio, índices de moedas, taxas de juros, mercadorias, índices de preços, índices de taxas de juros, ações de emissão de companhias abertas, índices de ações, debêntures simples ou conversíveis em ações e notas promissórias de emissão de sociedades por ações, destinadas a oferta pública. Definição semelhante das operações de swap é prevista na Circular BACEN n 3.099, de 26 de março de 2002, que regulamenta as operações de swap realizadas pelo BACEN.

${ }^{139}$ Ob. cit., p. 122.

${ }^{140}$ Como, por exemplo, os leilões de swap realizados para rolar as operações vencidas em 02 de janeiro de 2009, conforme consta expressamente nos Comunicados BACEN n⿳⺈ 17.835 , de 19 de dezembro de 2008, 17.829, de 18 de dezembro de 2008, 17.821, de 17 de dezembro de 2008, 17.816, de 16 de dezembro de 2008, 17.787, de 10 de dezembro de 2008, 17.783, de 09 de dezembro de 2008, e 17.778, de 08 de dezembro de 2008 . 
"(...) A demanda "virtual" por Dólares como "moeda de denominação" de ativos, e a demanda igualmente "virtual" para livrar-se do Dólar como "moeda de denominação" de passivos, afeta o preço do Dólar igualzinho a uma "fuga de capitais" sem que, necessariamente, um tostão cruze a fronteira.

Se quem vender o swap for um residente no país, nada aparece no balanço de pagamentos. Se for um não-residente, vai aparecer um pequeno "indício" da operação: o "prêmio" e o trânsito de margens. Nada que indique o tamanho da confusão." ${ }^{\text {141 }}$ (grifamos)

O autor alerta, em seguida, que os movimentos nos mercados de derivativos são dominantes na formação da taxa de câmbio, pois são muito maiores do que os fluxos do mercado primário. Para contê-los, é natural que o BACEN utilize títulos públicos indexados à moeda estrangeira ou também atue no mercado de derivativos, evitando usar exclusivamente as reservas cambiais para contê-los, já que essas são essenciais para as demandas reais dos compromissos assumidos no exterior.

De acordo com Márcio G. P. Garcia e FABio Urban pesquisas empíricas demonstram que a taxa de câmbio, em verdade, é formada primeiramente no mercado futuro de câmbio para, em seguida, influenciar na taxa praticada no mercado interbancário $^{142}$. Em verdade, existe uma influência recíproca entre as taxas praticadas nos dois mercados, o que leva a um ajuste mútuo. Entretanto, por serem mais líquidos que os mercados à vista, os mercados futuros recebem um volume maior de operações.

Por fim, cabe-nos tecer algumas considerações sobre a relação muito próxima entre a taxa de juros, a taxa de câmbio e a quantidade de moeda em circulação na economia.

O aumento da oferta de moeda a circular no mercado, além de causar uma queda nas taxas de juros praticadas no mercado, provoca, ainda, uma depreciação da moeda local frente a moedas estrangeiras no mercado de câmbio. Em sentido contrário, uma redução na oferta de moeda de um país ocasiona um aumento nas taxas de juros praticados e a apreciação da moeda local no mercado de câmbio.

\footnotetext{
${ }^{141}$ Gustavo H. B. Franco, Crônicas da Convergência: ensaios sobre temas já não tão polêmicos, pp. 322323.

${ }^{142}$ Ob. cit., pp. 37-38.
} 
As reservas internacionais do País, mantidas pelo BACEN, são compostas por ouro, títulos em moeda estrangeira ou moeda estrangeira em espécie. O que caracteriza as reservas internacionais é o fato de serem meios de pagamento aceitos universalmente ${ }^{143}$. Na contabilidade do BACEN, as reservas internacionais são registradas no ativo. A moeda em circulação e os depósitos dos bancos privados, por outro lado, representam contas do passivo do BACEN.

Quando o BACEN comparece ao mercado para vender títulos em moeda estrangeira, por exemplo, há uma diminuição na conta do ativo pelo valor dos títulos vendidos. Da mesma forma, partindo-se da premissa de que os títulos foram pagos em moeda, há uma redução correspondente na conta do passivo relativa a moeda em circulação. Os recursos em moeda recebidos pelo BACEN são retirados, então, de circulação por meio da sua atuação no mercado de câmbio, o que causa diminuição da oferta monetária da economia.

Para neutralizar o efeito das atuações no mercado de câmbio sobre a oferta de moeda, o BACEN pode realizar, concomitantemente, uma outra operação no mercado de câmbio em direção oposta. Esse tipo de atuação é chamado de intervenção cambial esterilizada.

Dessa forma, ao atuar no mercado de câmbio comprando ou vendendo moeda estrangeira, a autoridade monetária influencia na quantidade de moeda nacional que circula na economia e, por conseqüência, na taxa de juros praticada no mercado ${ }^{144}$.

No longo prazo, sabemos que, permanecendo tudo mais constante, um aumento na oferta da moeda de um país causa um aumento proporcional no nível de preços. O mesmo ocorre com a taxa de câmbio, que é o preço da moeda estrangeira. Dessa forma, no longo prazo, um aumento permanente na oferta de moeda causa proporcional depreciação da moeda nacional em relação às moedas estrangeiras.

\footnotetext{
${ }^{143}$ Ressalte-se que, por envolverem apenas pagamentos em moeda nacional, as operações no mercado de derivativos não afetam as reservas internacionais.

${ }^{144}$ A taxa de juros real (isto é, descontada a inflação), além de afetar a poupança e o investimento interno, influencia o investimento externo líquido do País, que corresponde à compra total de bens e serviços externos por residentes no País menos a compra de bens e serviços domésticos por residentes no exterior. Quanto maior a taxa de juros real interna, maior é o incentivo para que os residentes invistam no mercado doméstico e para que os não-residentes aumentem o volume de recursos investidos no País.
} 
O preço que equilibra a oferta e a demanda no mercado de câmbio é a taxa de câmbio real, que representa a relação efetiva entre os poderes de compra de cada uma das moedas envolvidas. Quando a taxa de câmbio real se aprecia, fica mais barata a aquisição de bens e serviços no exterior e, por conseqüência, o volume de importações aumenta e o volume de exportações diminui.

Diante das breves noções acima apresentadas, passa a ficar mais clara a forma como a atuação do Estado pode influenciar as variáveis da economia.

\subsection{REGIMES CAMBIAIS.}

Os regimes cambiais indicam se e em que medida o Estado atua na administração das taxas de câmbio ${ }^{145}$ e cada regime traz conseqüências diversas em termos de política monetária e fiscal.

No regime de taxas de câmbio fixas, o valor da moeda nacional, em comparação com as moedas de outros países é previamente determinável e deve ser imutável. O Estado, através do Banco Central, intervém no mercado de câmbio para equilibrar a oferta e a demanda de moeda estrangeira no nível da taxa de câmbio previamente fixada. Em outras palavras, a autoridade monetária compromete-se a comprar e a vender moeda estrangeira no mercado de câmbio, ou utilizar de algum outro instrumento de política cambial, de forma a ajustar a taxa de câmbio para o valor previamente determinado. Caso a demanda por moeda estrangeira aumente, o Banco Central vende moeda estrangeira à taxa fixada para evitar sua valorização. Se, ao contrário, há um excesso de oferta de moeda estrangeira, o Banco Central deve atuar no mercado adquirindo moeda estrangeira à mesma taxa de câmbio para evitar sua desvalorização frente à moeda local. Se o Banco Central não remover os excessos de oferta ou demanda de moeda estrangeira, a taxa de câmbio terá que ser mudada para que um novo equilíbrio seja atingido ${ }^{146}$.

\footnotetext{
145 Sobre os regimes cambiais, consultamos MARIO HENRIQUE SIMONSEN e RUBENS PENHA CYSNE (Macroeconomia, pp. 99-106), AMAURY PATRICK GREMAUD, MARCO ANTÔNIO SANDOVAL DE VAsconcellos e Rudinei Toneto Júnior (ob. cit., pp. 264-299), e PAUl R. KRUGMAN e MAURICE OBSTFLED, ob. cit., pp. 359-395).

${ }^{146}$ O regime de taxas de câmbio fixas foi adotado na Argentina entre 1991 e 2001. O Banco Central negociava dólares de forma a manter a paridade US $\$ 1,00=1$ peso argentino. Esse regime costuma ser
} 
O regime de câmbio de taxas fixas tem a vantagem de facilitar a tomada de decisão pelos agentes econômicos, mas não há segurança de que a oferta e a demanda de moeda estrangeira se equilibrarão naturalmente na taxa fixada pelo governo. O governo deve, então, manter estoque adequado de reservas cambiais, que lhe permitam intervir no mercado em caso de excesso de demanda ou de oferta de moeda estrangeira, com o objetivo de manter a taxa previamente estipulada.

No regime de taxas de câmbio flutuantes ou livres, o Banco Central não negocia moeda estrangeira para influenciar a taxa de câmbio, mas apenas para satisfazer as suas necessidades de moeda estrangeira. Nesse regime, a taxa de câmbio oscila de acordo com as forças do mercado, isto é, de acordo com a oferta e demanda da moeda estrangeira. O balanço de pagamentos equilibra-se automaticamente, tornando-se irrelevante o nível de reservas de divisas.

A maior dificuldade relacionada com o regime de taxas de câmbio flutuantes é que, como a taxa de câmbio é determinada pela oferta e pela demanda no mercado, não há qualquer segurança de estabilidade cambial. Se a percepção do mercado externo é positiva e o país atrai um maior volume de capitais, a moeda nacional se valoriza. Se a percepção do mercado muda, a desvalorização é inevitável. É muito difícil encontrarmos no mundo atual, mesmo nos países mais industrializados, um regime de taxas puramente flutuantes ${ }^{147}$.

Entre os dois extremos indicados acima, há alguns tipos de regime que adotam características de ambos, em maior ou menor grau. Podemos citar o regime de bandas cambiais, no qual se admite a flutuação da taxa de câmbio dentro de um limite mínimo e um limite máximo, fixados pelo Banco Central. Dentro desse limite, a taxa de câmbio flutua livremente, sem a intervenção da autoridade monetária. Todavia, caso os limites mínino ou máximo sejam atingidos (ou estejam prestes a serem atingidos), a

adotado por países com problemas inflacionários, uma vez que os preços dos produtos importados ficam constantes (ANTONIO EVARISTO TEIXEIRA LANZANA, Economia Brasileira: fundamentos e atualidade, p. 73). ${ }^{147}$ De acordo com classificação de regimes cambiais divulgado pelo Fundo Monetário Nacional em 2004, cerca de 36 países, na época, admitiam a flutuação livre da sua moeda como regra, inclusive o Brasil (Classification of Exchange Rate Arrangements and Monetary Policy Frameworks). Em todos eles, o regime de flutuação é conjugado com algum tipo de política monetária a indicar a atuação do Estado de modo mais amplo na economia, como a fixação de âncoras cambiais ou de limites no crescimento da oferta monetária. $\mathrm{O}$ trabalho indica o Brasil como adepto de regime de metas de inflação, que consiste no anúncio público de metas de inflação a médio prazo associado ao compromisso institucional pela autoridade monetária de atingir essas metas. 
autoridade monetária intervém no mercado, com o fim de manter a taxa de câmbio dentro dos limites determinados.

O regime adotado pela maior dos países industrializados atualmente é o chamado de dirty floating ou flutuação suja, que consiste em regime de taxas flutuantes administrada, com intervenções esporádicas do Banco Central. A autoridade intervém para suavizar oscilações indesejadas da taxa de câmbio, notadamente decorrentes de manobras especulativas, e não para atingir um nível de taxa de câmbio previamente determinado. A grande dificuldade, nesses casos, reside-se em saber em que medida a variação no valor da taxa de câmbio deve-se a uma tendência natural ou se provém de uma manobra especulativa, caso em que a intervenção do Banco Central se torna desejável ${ }^{148}$. Esse é o regime adotado pelo Brasil na atualidade.

Não parece haver consenso, entre os estudiosos, de qual regime cambial seria capaz de proporcionar o maior benefício para a sociedade. A opinião dos economistas sobre qual seria o regime cambiou ideal oscilou muito nos últimos cem anos. Na América Latina, diversos "experimentos" na área foram levados a cabo. A década de 1990 começou com um consenso em torno das vantagens do câmbio fixo e terminou com os estudiosos convencidos da superioridade do câmbio flutuante, muitas vezes esquecendo-se que o sucesso do regime cambial não é independente dos fundamentos macroeconômicos da economia e das circunstâncias históricas e institucionais do país ${ }^{149}$.

O debate sobre as vantagens do câmbio flutuante vem ao encontro da ideologia neoliberal, que propugna pelo maior afastamento do Estado sobre o processo econômico. Mas, como adverte MAURício MEsQuita MoreIRA ${ }^{150}$, a lua-de-mel dos economistas com o regime de câmbio flutuante tem caído por terra nos últimos anos, a partir da constatação de que a flutuação implica a possibilidade de movimentos da taxa de câmbio para os dois lados; isto é, causando a depreciação ou a apreciação da moeda nacional. No regime de câmbio flutuante, não há como garantir que a taxa de câmbio se mova sempre para o "lado correto". Nas palavras de GuSTAvo H. B. FrAnCO, "a flutuação

\footnotetext{
${ }^{148}$ Podemos citar ainda o sistema de taxa real de câmbio fixa, o qual implica a realização de desvalorizações nominais de câmbio em curtos intervalos de tempo, pela diferença entre a taxa de inflação interna e a da moeda estrangeira de referência, e o regime de prefixação das desvalorizações cambiais, por meio do qual o Banco Central determina, por certo período de tempo, a cotação da moeda estrangeira de referência.

${ }^{149}$ Maurício Mesquita Moreira, Câmbio e Crescimento na América Latina, pp. 135-157.

${ }^{150}$ Ob. cit., p. 136.
} 
pura tem uma característica da qual não se escapa: as autoridades devem estar preparadas para aceitar aquilo que o mercado trouxer"151.

Em verdade, o debate sobre a adequação ou não de um regime cambial está intimamente ligado à discussão, também comum e igualmente polêmica, sobre qual a taxa de câmbio de equilíbrio ou taxa de câmbio correta de um país, ou seja, aquela capaz de proporcionar o adequado crescimento econômico ou, em última instância, o maior bemestar para a sociedade ${ }^{152}$.

Os defensores do câmbio flutuante, em última análise, apregoam que a taxa de câmbio de equilíbrio é sempre aquela determinada pelo mercado, através da livre atuação de suas forças. Os que defendem algum nível de intervenção do Estado para determinação da taxa de câmbio já entendem que o mercado sozinho não é capaz de determinar a taxa de câmbio mais equilibrada para a economia nacional, sendo necessária, portanto, a participação do Estado para garantir o equilíbrio. Entre esse último grupo, há diversas divergências, também, sobre o nível dessa intervenção e sobre qual, na prática, é a taxa de câmbio de equilíbrio de uma economia em cada momento histórico.

Entre o final da década de 1960 e o início dos anos 90, foi adotado no Brasil, em termos gerais, um regime de minidesvalorizações. Nesse regime, as taxas de câmbio flutuavam, mas a autoridade monetária intervinha no mercado com o objetivo de manter certa paridade real da moeda. A taxa de câmbio nominal era desvalorizada em intervalos freqüentes e a taxas pequenas, com o objetivo de ajustá-la à diferença entre a taxa de inflação interna e a taxa de inflação internacional. "A idéia das "minis' é simplesmente que haja uma política de administrar pequenas mudanças na taxa de câmbio, a fim de evitar mudanças abruptas no valor da moeda doméstica" ${ }^{153}$.

Em março de 1990, foi anunciada a adoção do câmbio flutuante. O BACEN deixou de determinar a taxa de câmbio oficial, e as autoridades passaram a informar que o BACEN passaria a pautar as suas intervenções no mercado pelos níveis de reservas internacionais. Na prática, as intervenções do BACEN no mercado de câmbio entre 1990 e

\footnotetext{
${ }^{151}$ Crônicas da Convergência: ensaios sobre temas já não tão polêmicos, p. 344.

152 ÁlVARO ANTÔNIO ZINI JÚNIOR, ao tratar do tema, diz que "a taxa de câmbio é adequada quando reflete a competitividade externa de um país e a confiança dos agentes econômicos sobre fatores macroeconômicos fundamentais". O próprio autor reconhece, contudo, a dificuldade de determinação dessa taxa na prática (Taxa de Câmbio e Política Cambial, p. 19).

${ }_{153}$ ÁlvARO ANTÔNIO ZINI JÚNIOR, ob. cit., p. 30. Esse texto foi também consultado para a análise histórica que segue do regime cambial no início da década de 1990.
} 
1991 tiveram outras motivações além da administração do nível de reservas internacionais, como entre maio e setembro de 1990, quando atuou de forma a reduzir o ágio entre o mercado paralelo e o oficial, ao vender ouro à taxa de câmbio do paralelo e comprar dólar no oficial, e a partir do final de setembro, quando procurou fazer com que o valor da taxa de câmbio real se recuperasse para evitar uma maior queda no volume das exportações.

Na época da implementação do Plano Real, em 1994, foi estabelecido um regime de livre flutuação da taxa de câmbio. A estratégia adotada pelo governo, na época, foi de estabelecer uma âncora monetária, ou seja, limitar as emissões de moeda (o que teria o efeito de diminuir o impacto inflacionário).

\section{Como explicou Gustavo H. B. Franco:}

“operava-se com uma taxa de câmbio flexível, novidade sem precedentes no mercado de câmbio brasileiro, e as autoridades não se furtavam a deixar claras duas importantes inovações: (i) que a taxa de câmbio estaria, doravante, inteiramente desindexada, abolindo-se, assim, de uma penada, a noção de que o câmbio era um 'preço público' sujeito à indexação automática e aos incansáveis pleitos de correção de 'defasagem'; (ii) que a sustentação da taxa de câmbio em níveis artificiais resultava em compras e/ou vendas sistemáticas, como claramente vinha ocorrendo há tempos, e que os limites de emissão de moeda impediria que isso prosseguisse" 154 .

Iniciou-se um processo de apreciação da moeda nacional e, para evitar uma apreciação ainda maior, fixou-se um valor mínimo ao qual o BACEN compraria todos os dólares que surgissem no mercado. A Resolução CMN n² 2.087, de 30 de junho de 1994, determinou que o BACEN operaria com o dólar dos Estados Unidos no segmento de câmbio de taxas livres à taxa de câmbio de venda de $\mathrm{R} \$ 1,00$. Alguns meses depois, em 20 de setembro de 1994, a Resolução CMN n 2.110 determinou que o BACEN ficaria obrigado a vender, no mercado interbancário, qualquer quantidade de dólares demandada à taxa cambial de $\mathrm{R} \$ 1,00$ por dólar.

O regime foi alterado formalmente para uma sistemática de bandas cambiais em 30 de janeiro de 1996, por meio da Resolução CMN n 2.234. De acordo com essa Resolução, as operações de câmbio do BACEN nos mercados interbancários obedeceriam

\footnotetext{
${ }^{154}$ O Plano Real e Outros Ensaios, p. 59.
} 
a faixas de flutuação que seriam definidas periodicamente pelo BACEN. Foi previsto ainda, expressamente, que o BACEN interviria obrigatoriamente nos mercados sempre que os limites das faixas de flutuação fossem atingidos pelas taxas praticadas no mercado.

Em janeiro de 1999, com a eclosão de uma nova crise cambial e a alta desvalorização da moeda nacional frente ao dólar, o BACEN decidiu adotar um regime de taxas de câmbio flutuantes, com intervenções esporádicas no mercado de câmbio. Em 18 de janeiro de 1999, o Diretor de Assuntos Internacionais do BACEN divulgou a mudança do regime cambial ao mercado através do Comunicado $\mathrm{n}^{\circ} 6.565$, dispondo que, a partir daquele dia, “o Banco Central do Brasil deixará que o mercado interbancário (segmentos livre e flutuante) defina a taxa de câmbio". Acrescentou o Comunicado, ainda, que o BACEN poderia intervir nos mercados, ocasionalmente e de forma limitada, com o objetivo de conter movimentos desordenados das taxas de câmbio.

A Resolução CMN n 2.234/1996, que instituiu o regime de bandas cambiais e determinou a intervenção obrigatória do BACEN no mercado de câmbio para garantir que a taxa de câmbio praticada estivesse situada dentro das faixas de flutuação, foi revogada expressamente apenas em 17 de janeiro de 2002, pela Resolução CMN n ${ }^{\circ} 2.234$, que revogou diversos regras "que se encontra[va]m sem função por decurso de prazo ou por regulamentação superveniente".

O assunto foi levado à apreciação do Superior Tribunal de Justiça (STJ). No caso, sociedade que havia sofrido perdas em decorrência da maxidesvalorização do real ocorrida em janeiro de 1999 requereu indenização da União e do BACEN por aquelas perdas. Sustentou o requerente que o BACEN tinha a obrigação de intervir no mercado para garantir que a taxa de câmbio permanecesse dentro das faixas de flutuação, conforme determinado na Resolução CMN n 2.234/1996, e que o BACEN não tinha competência para mudar o regime de câmbio ${ }^{155}$.

A Primeira Turma do STJ decidiu, por unanimidade, negar o pedido de indenização, reconhecendo a competência do BACEN para alterar o regime cambial, com base no disposto na Lei $\mathrm{n}^{\circ} 4.595 / 1964$. A mesma matéria foi apreciada em outras

\footnotetext{
${ }^{155}$ Recurso Especial no 549.873/SC (2003/0106472-5), 1ª Turma, r. o Ministro Luiz Fux, j. 10.08.2004.
} 
oportunidades $^{156}$ pelo Tribunal e, em todas elas, teve o mesmo desfecho. Destacamos a ementa do acórdão do Recurso 1.060.604-RS:

“ADMINISTRATIVO. RECURSO ESPECIAL. RESPONSABILIDADE CIVIL DO ESTADO. IMPORTAÇÃO. OBRIGAÇÕES ASSUMIDAS EM MOEDA ESTRANGEIRA. PARIDADE CAMBIAL. REGIME DE BANDAS CAMBIAIS INSTITUÍDO PELO BACEN. LIBERAÇÃO PARA QUE O MERCADO DEFINISSE A TAXA DE CÂMBIO. INEXISTÊNCIA DE IRREGULARIDADE. HONORÁRIOS ADVOCATÍCIOS. FIXAÇÃO. MATÉRIA DE PROVA. SÚMULA 7/STJ.

1. A prerrogativa atribuída ao Banco Central do Brasil, de intervir no mercado para garantir a estabilidade da moeda nacional, está expressamente prevista no art. 11, III, da Lei 4.595/64. Entretanto, o Banco Central do Brasil, na sua missão de manter a estabilidade das taxas cambiais, poderá, quando muito, alterar as condições normais de oferta e procura, vendendo ou comprando moeda estrangeira e puxando, para cima ou para baixo, o seu valor equivalente em moeda nacional. Isso, porque a razão existente entre a moeda nacional e outras moedas estrangeiras não depende apenas do mercado interno, mas de inúmeros outros fatores, muitas vezes relacionados a fatos imprevisíveis.

2. São extremamente previsíveis, por outro lado, as variações da moeda nacional frente à norte-americana, daí é que deve surgir a prudência do importador, que tem em suas mãos a possibilidade de amenizar os riscos inerentes ao negócio assumido em moeda estrangeira, mediante a contratação de seguros (operações de cobertura - hedge - realizadas por meio de operações de swap) contra os efeitos das variações de câmbio.

3. Conforme assentado pelo eminente Ministro Luiz Fux no julgamento dos REsps 549.873/SC e 614.048/RS, "a ingerência de fatores exteriores aliada à possibilidade de o particular prevenir-se contra esses fatores alheios à vontade estatal, acrescido da mera natureza indicativa da política econômica revela a ausência de responsabilização do Estado ".

4. É inviável reapreciar, em sede de recurso especial, a fixação dos honorários advocatícios, por demandar o reexame de matéria fática.

5. Recurso especial parcialmente conhecido e, nessa parte, desprovido.” (grifamos)

156 Recurso Especial n ${ }^{\circ}$ 614.048/RS (2003/0225547-0), 1 ${ }^{\mathrm{a}}$ Turma, r. o Ministro Luiz Fux, j. 15.03.2005, Recurso Especial n ${ }^{\circ}$ 639. 170/PR (2004/0004724-2), $1^{\text {a }}$ Turma, r. a Ministra Denise Arruda, j. 13.03.2007, e Recurso Especial n 1.060.604-RS (2008/0113067-3), 1 a Turma, r. a Ministra Denise Arruda, j. 23.09.2008. 
O regime cambial de taxas flutuantes administradas, previsto no Comunicado $\mathrm{n}^{\circ} 6.565 / 1999$, mantém-se até hoje. Na prática, sabe-se que, sempre que o BACEN entende que as taxas de câmbio estão em desacordo com o que considera adequado para a economia do País, intervém no mercado, com o objetivo de garantir uma taxa de câmbio condizente com os objetivos de política econômica.

A determinação da taxa de câmbio mais adequada é assunto de difícil consenso, e reflete o embate entre os centros de poder existentes na sociedade. Os exportadores tendem a reclamar sempre que a moeda nacional se aprecia, ocasionando uma redução, em moeda local, das suas receitas. Por outro lado, os setores da economia que dependem de maciça importação defendem a manutenção de uma política tendente a preservar o poder de compra da moeda nacional frente a moedas estrangeiras.

O que nos parece importante ressaltar, nesse contexto, é que a omissão deliberada do Estado na administração da taxa de câmbio, como política institucionalizada em um regime de taxas puramente flutuantes, não é admitida no ordenamento jurídico brasileiro.

Na medida em que a Constituição Federal impõe ao Estado o poder-dever de dar concretude aos objetivos eleitos como prioritários pela sociedade, o Estado deve agir de forma a implementá-los. Isso significa dizer que, caso a taxa de câmbio atinja patamares que possam prejudicar a economia doméstica como um todo ou algum setor específico que seja fundamental para o seu crescimento, o Estado deve atuar de forma a alterar esse cenário.

Nem toda omissão do Estado é contrária ao ordenamento. É possível que, em alguns momentos, a melhor maneira de preservar a economia seja justamente a abstenção do Estado, dada a conjuntura verificada na realidade concreta. O que parece ser contrário ao ordenamento é a omissão como política, como regra institucionalizada, independentemente das circunstâncias que a vida econômica apresenta.

Deve-se ressaltar, ainda, que as decisões de política cambial estão sujeitas, elas mesmas, a verificação de legalidade e consonância com os preceitos constitucionais. $\mathrm{O}$ discurso sobre a política cambial é freqüentemente permeado por discussões técnicoeconômicas, o que lhe confere uma aparência de objetividade e afasta uma avaliação da 
legalidade e da legitimidade das decisões tomadas pelo Estado. Essa situação é reforçada pelo argumento de que o Estado é dotado, nessa área, de um poder discricionário amplo, que afastaria o controle judicial de seus atos ${ }^{157}$.

\subsection{CONTROLES CAMBIAIS.}

Os controles cambiais referem-se aos mecanismos criados pelo Estado para impedir, dificultar ou monitorar a livre movimentação de recursos através de suas fronteiras, com o intuito de preservar ou administrar as reservas de divisas com as quais o Estado e os seus nacionais possam pagar as obrigações contraídas no exterior, entre elas os empréstimos externos e as importações. Normalmente, quando se faz referência aos controles cambiais, está-se referindo primordialmente à imposição de limites à movimentação de capitais.

Historicamente, a instituição dos controles cambiais tem lugar em economias que vivenciam permanente ou periódica escassez de divisas. A adoção generalizada dos controles cambiais teve início com o fim da Primeira Guerra Mundial, em reação à situação econômica fragilizada em que se encontraram os países envolvidos, mas se consolidou com a crise mundial de 1929. A maior parte dos países, desde então, tem vivenciado algum tipo de controle sobre o câmbio ${ }^{158}$.

PÉRSIO ARIDA explica que a instituição de controles cambiais, muitas vezes, encontra-se fundada na necessidade de contrabalançar distorções, como para inibir a especulação no mercado cambial, evitando tanto a apreciação quanto a depreciação exageradas, ou para evitar uma fuga de capitais, que poderia aumentar a vulnerabilidade do País a processos especulativos ${ }^{159}$.

No Brasil, os controles passam a existir a partir da década de 1930, também em decorrência dos reflexos provocados pela crise de 1929. A economia brasileira, pelo menos até o final da década de 1980, tem passado por longos períodos de escassez de

\footnotetext{
${ }^{157}$ Sobre discricionariedade, ver nossos comentários na Seção 5 (“As formas de atuação do Estado no e sobre o processo econômico"), acima.

${ }^{158}$ LUIZ GASTÃo PAES DE BARRos LEÃES, Controle Cambial e Fluxo Internacional de Divisas, p. 11.

${ }^{159}$ Aspectos Macroeconômicos da Conversibilidade: uma discussão do caso brasileiro, p. 2-3
} 
divisas que justificaram a manutenção de um sistema complexo de normas tendentes a proporcionar um estrito controle das operações cambiais por parte da autoridade monetária.

No capítulo quatro dessa dissertação, traremos um histórico do arcabouço jurídico que regula as operações de câmbio no País. Procura-se assim observar de que forma os controles cambiais brasileiros vêm se manifestando desde o início do século passado, para, enfim, demonstrar uma tendência de afrouxamento desses controles a partir da década de $1990^{160}$. De forma geral, podemos dizer que a intensidade dos controles cambiais brasileiros tem variado no tempo, dependendo da conjuntura econômica do momento e do embate das forças políticas existentes ${ }^{161}$.

Também no quarto capítulo, traremos um quadro normativo do câmbio no Brasil de hoje, em que procuramos apontar as principais restrições ainda existentes.

\footnotetext{
160 Observe-se que, na nossa análise, não trataremos, especificamente, da imposição de tributos como instrumento de política cambial.

${ }^{161}$ Haroldo Malheiros Duclerc Verçosa, Notas sobre o Sistema de Controle de Câmbio no Brasil, pp. 24-45.
} 


\section{III}

\section{POLÍTICA PÚBLICA}

SUMÁRIO: 7. Política pública: caracterização. - 8. Política pública e política econômica. - 9. Os fins da política pública na Constituição de 1988. - 9.1. A ordem econômica na Constituição de 1988: fundamentos, princípios e fins. - 9.2. O desenvolvimento nacional como síntese.

\section{POLÍTICA PÚBLICA: CARACTERIZAÇÃO.}

Apenas recentemente, na história da humanidade, o tema das políticas públicas passou a ser objeto de interesse dos estudiosos do direito. É a partir das Constituições Econômicas que a discussão sobre políticas públicas passa a fazer sentido, na medida em que elas passam a fixar objetivos sociais a serem perseguidos pelo Estado. $\mathrm{O}$ direito torna-se, além de meio de ordenação da realidade social, instrumento de governo a partir do qual o caráter transformador das Constituições Econômicas pode ser concretizado.

FÁBIO KONDER COMPARATO ${ }^{162}$ trata as políticas públicas como programas de ação que visam estabelecer uma meta ou finalidade coletiva, em contraposição aos princípios, que tendem a estabelecer um direito individual. A política pública não é uma norma nem um ato, mas uma atividade, assim entendida como "conjunto organizado de normas e atos tendentes à realização de um objetivo determinado". Como atividade, a política é composta de normas, decisões e atos, unificados pela finalidade. O juízo de

\footnotetext{
${ }^{162}$ Ensaio sobre o Juízo de Constitucionalidade de Políticas Públicas, pp. 49-63.
} 
validade sobre cada um deles (ou seja, sobre a política, de um lado, e sobre os atos, decisões e normas que a compõe, de outro) deve ser feito separadamente.

As Constituições Dirigentes determinam certos objetivos aos órgãos estatais e à sociedade civil, os quais podem ser gerais (como os objetivos indicados no artigo $3^{\circ}$ da Constituição Federal de 1988) ou especiais (como os objetivos da ordem econômica, elencados no artigo 170 da Carta Magna); por certo, os objetivos especiais devem estar coordenados com os gerais ${ }^{163}$. Tais objetivos são, na opinião do autor, inquestionavelmente vinculantes para todos os órgãos estatais e para todos os detentores do poder econômico ou social.

Destaca, ainda, COMPARATo que a grande maioria das leis, atualmente, está englobada em alguma política pública e, portanto, "tem por função não mais a declaração de direitos e deveres em situações jurídicas permanentes, mas a solução de questões de conjuntura (Massnahmegesetze), ou então o direcionamento, por meio de incentivos ou desincentivos, das atividades privadas, sobretudo no âmbito empresarial (Lenkungsgesetze), ou ainda a regulação de procedimentos no campo administrativo (Steuerungsgesetze)". A tendência geral é de alargamento da competência normativa do Governo, tanto na instância central, por meio de decretos-leis ou medidas provisórias, mas também no plano inferior das organizações administrativas autônomas.

CRISTIANE DERANI define a política pública como "um conjunto de ações coordenadas pelos entes estatais, em grande parte por eles realizadas, destinadas a alterar as relações sociais existentes. Como prática estatal, surge e se cristaliza por norma jurídica. A política pública é composta de ações estatais e decisões administrativas competentes”, e usa instrumentos jurídicos para concretização de fins políticos, na medida em que "toma preceitos normativos para a realização de ações voltadas àqueles objetivos que se reconhecem como necessários para a construção do bem-estar" ${ }^{\text {"164 }}$.

É interessante notar o destaque dado pela autora à potencialidade de mudança da realidade social contida nas políticas públicas. Os princípios são fundamentais para indicar os fins que devem ser com elas alcançados, bem como balizam a própria atividade política. As políticas públicas servem como mecanismos a propiciar uma

\footnotetext{
${ }^{163}$ Trataremos sobre os objetivos fixados na Constituição Federal de 1988 na Seção 9 deste trabalho ("Os fins da política pública na Constituição de 1988”) e nas respectivas subseções.

${ }^{164}$ Política Pública e a Norma Política, pp. 131-142.
} 
verdadeira transformação na realidade social ao determinar que a atuação do Estado e da generalidade das pessoas devem ser condizentes com os fins por elas indicados.

MARIA PAUla DALlari BuCci trata a política pública como "programa de ação governamental que resulta de um processo ou conjunto de processos juridicamente regulados - processo eleitoral, processo de planejamento, processo de governo, processo orçamentário, processo legislativo, processo administrativo, processo judicial - visando coordenar os meios à disposição do Estado e as atividades privadas, para a realização de objetivos socialmente relevantes e politicamente determinados. Como tipo ideal, a política pública deve visar a realização de objetivos definidos, expressando a seleção de prioridades, a reserva de meios necessários à sua consecução e o intervalo de tempo em que se espera o atingimento dos resultados" ${ }^{\prime 165}$.

É programa de ação governamental na medida em que consiste em diversas medidas coordenadas tendentes a movimentar a máquina do governo para a realização de algum propósito de ordem pública ou concretização de algum direito. Acrescenta a autora que a política pública tem, ainda, como caráter distintivo, o fato de que visa atingir "objetivos sociais em tempo e quantidade previamente determinados" e que tem um componente de ação estratégica, pois “incorpora elementos sobre a ação necessária e possível naquele momento determinado, naquele conjunto institucional e projeta-os para o futuro mais próximo" ${ }^{\text {"166. }}$

A política pública é vista, portanto, como programa de ação, desenvolvido com o intuito de tornar reais os objetivos definidos pela sociedade como prioritários ou estabelecer uma finalidade coletiva ${ }^{167}$. Esses objetivos são fixados, dentro do ordenamento, por meio dos textos normativos descritos como policies, por RONALD DWORKIN, ou como normas-objetivo, por EROS ROBERTO GRAU.

RONALD DWORKIN, ao criticar o positivismo por ignorar o importante papel de padrões de conduta (standards) que não são regras, diferencia tais padrões de conduta entre princípios (principles) e políticas ou diretrizes (policies). A política ou diretriz é um tipo de standard que determina um objetivo a ser alcançado, geralmente uma melhoria em algum aspecto econômico, político ou social de uma comunidade; alguns desses objetivos

\footnotetext{
165 Maria Paula Dallari Bucci, O Conceito de Política Pública em Direito, p. 39.

${ }^{166}$ Maria Paula Dallari Bucci, O Conceito de Política Pública em Direito, pp. 14, 17 e 19.

${ }^{167}$ FÁBIO Konder COMPARATO, Ensaio sobre o Juízo de Constitucionalidade de Políticas Públicas, p. 57.
} 
são negativos, no sentido de que visam proteger algum aspecto presente da sociedade contra mudança adversa. O princípio por outro lado, é um standard que deve ser observado não porque proporcionará uma melhoria ou assegurará algum aspecto econômico, político ou social desejável, mas porque é um requisito de justiça, honestidade ou de alguma outra dimensão de moralidade ${ }^{168}$.

Mais adiante, o autor discorre sobre a fundamentação de decisões judiciais na área cível, e distingue os "argumentos de política" (arguments of policy) dos "argumentos de princípio" (arguments of principle). Os argumentos de princípio servem para justificar uma decisão política que beneficia alguma pessoa ou grupo sob o fundamento de que tal pessoa ou grupo tem direito ao benefício. Já os argumentos de política procuram demonstrar que, apesar dos beneficiados de fato não terem direito ao benefício, conceder-lhes o benefício ajudaria na conquista de algum objetivo coletivo da comunidade política ${ }^{169}$.

EROS ROBERTO GRAU destaca a proximidade entre as "policies" de DWORKIN e as normas-objetivo. As normas-objetivo "explicita[m] resultados e fins em relação a cuja realização estão comprometidas outras normas - estas, de conduta e de organização. A importância delas, de outra parte, como critério indiciário dos fins a que se voltam estas últimas, normas de conduta e de organização - o que viabiliza a fluente perquirição de sua eficácia -, é extremada"170.

As normas-objetivo enunciam os fins a serem buscados pela política pública, positivando-os. Determinam, ainda, o próprio processo de interpretação do direito e, nesse sentido, cumprem papel análogo ao dos princípios.

\footnotetext{
${ }^{168}$ Nas palavras do autor: "I call a 'policy' that kind of standard that sets out a goal to be reached, generally an improvement in some economic, political, or social feature of the community (though some goals are negative, in that they stipulate that some present feature is to be protected from adverse change). I call a 'principle' a standard that is to be observed, not because it will advance or secure an economic, political, or social situation deemed desirable, because it is a requirement of justice or fairness or some other dimension of morality" [tradução livre: "Eu chamo de 'política' aquele tipo de diretriz que determina um objetivo a ser atingido, geralmente em algum aspecto econômico, político ou social da comunidade (apesar de que alguns objetivos são negativos, já que estipulam que algum aspecto presente deve ser protegido de mudança adversa). Eu chamo de 'princípio' uma diretriz que deve ser observada não porque propiciará ou assegurará uma situação econômica, política ou social considerada desejável, mas porque é uma exigência de justiça ou honestidade ou de alguma outra dimensão da moralidade"] (Taking Rights Seriously, p. 22).

${ }^{169}$ Ob. cit., p. 294.

${ }^{170}$ Ensaio e Discurso sobre a Interpretação/Aplicação do Direito, pp. 128-132.
} 
Resumindo o que foi dito acima, podemos dizer que, na visão dos doutrinadores consultados, as políticas públicas são programas de ação direcionados ao Poder Público e à população em geral, cujo objetivo é implementar os fins eleitos pela sociedade, concretizando, assim, o potencial transformador previsto na Constituição. As políticas públicas são positivadas, no ordenamento jurídico, por normas-objetivo ou policies, as quais indicam os fins a serem perseguidos e servem como critério interpretativo do direito, bem como por normas de conduta e de organização.

O direito é não só instrumento de implementação das políticas públicas, mas é nele que são determinados os fundamentos e limites das políticas públicas.

A atuação do Estado deve sempre ser pautada pela legalidade. No caso das políticas públicas, o juízo de legalidade deve abarcar não apenas os atos da Administração realizados no âmbito de uma determinada política, mas a própria política em si. A verificação de compatibilidade de uma determinada política com a ordem jurídica vigente inclui necessariamente a apreciação de se os fins perseguidos, na prática, pelo Estado condizem com aqueles determinados no ordenamento, o que ultrapassa a análise pura e simples dos aspectos formais dos atos emanados do Poder Público e exige a apreciação de mérito sobre as decisões tomadas ${ }^{171}$.

Nesse sentido, parece-nos que o controle da inflação como diretriz da política econômica, decorrente da sistemática de metas para a inflação prevista no Decreto $\mathrm{n}^{\circ} 3.088$, de 21 de junho de 1999, somente encontra respaldo na ordem jurídica vigente se for considerada instrumento para concretização dos objetivos de bem-estar previstos na Constituição Federal. O controle da inflação, como fim em si mesmo, não encontra compatibilidade com a ordem jurídica.

A nosso ver, o juízo de legalidade das políticas públicas inclui, ainda, a verificação de eventual omissão do Estado na sua implementação. Ao determinar os objetivos a serem perseguidos, a ordem jurídica não concede uma faculdade ao Estado para

\footnotetext{
${ }^{171}$ Sobre esse ponto, remetemos à Seção 5 deste trabalho (“As formas de atuação do Estado no e sobre o processo econômico"), onde demonstramos, ao analisar a capacidade normativa de conjuntura, que as decisões judiciais no Brasil, quando envolvem algum aspecto de política econômica, tendem a se limitar a uma análise formal dos casos, consistente na verificação de se a autoridade que emitiu determinado ato tem competência ou atribuição para fazê-lo. O mérito da decisão é ignorado, sob o argumento de tratar-se de aspecto relegado à discricionariedade da autoridade.
} 
sua realização. Ao contrário, impõe ao Poder Público o dever de perseguir a sua consecução.

\section{POLÍTICA PÚBLICA E POLÍTICA ECONÔMICA.}

Alguns autores, como Eros Roberto GraU ${ }^{172}$ e GiOvani Clark ${ }^{173}$, defendem que a política econômica é uma espécie de política pública. De acordo com esse entendimento, as políticas públicas englobariam toda forma de atuação estatal no campo social, inclusive na economia. Assim, dentro do gênero política pública teríamos diversas espécies de política, caracterizadas pela sua área específica de atuação ou pelo seu objetivo principal, tais como, por exemplo, a política de saúde, de educação, de proteção ao meioambiente e, também, a política econômica.

Como observamos no capítulo precedente, em nossa opinião a política econômica coincide com a própria atuação do Estado na e sobre a vida econômica. Toda vez que o Estado age na economia está praticando um ato de política econômica. A política pública, todavia, é vista como programa de ação do Estado destinado à implementação de alguma ou algumas finalidades previstas na ordem e que, como afirma MARIA PAULA DALLARI, distingue-se por que almeja atingir "objetivos sociais em tempo e quantidade previamente determinados"174. Seria possível considerar a política econômica como espécie de política pública se entendermos que a política econômica, em verdade, é um programa de ação específico, a ser implementado no domínio econômico.

Mais do que definir se estamos tratando de gênero e espécie ou de coisas diversas, temos como fundamental deixar claro o nível de influência que cada política exerce sobre a sua esfera específica de atuação e sobre a realidade social como um todo, o que, certamente, destaca a importância do estudo da política econômica, pela generalidade

\footnotetext{
${ }^{172}$ O Direito Posto e o Direito Pressuposto, p. 26. Diz o autor: "Essas políticas [públicas], contudo, não se reduzem à categoria das políticas econômicas; englobam, de modo mais amplo, todo o conjunto de atuações estatais no campo social (políticas sociais). A expressão políticas públicas designa todas as atuações do Estado, cobrindo todas as formas de intervenção do poder público na vida social. E de tal forma isso se institucionaliza que o próprio direito, neste quadro, passa a manifestar-se como uma política pública - o direito é também, ele próprio, uma política pública" (destaques no original).

${ }^{173}$ Política Econômica e Estado, p. 41.

${ }^{174}$ O Conceito de Política Pública em Direito, p. 17.
} 
de seus efeitos e capacidade de proporcionar as condições necessárias para a implementação de outras políticas públicas mais específicas.

Quando age de forma a implementar uma política pública, o Estado influencia a economia como um todo, mas o nível de influência depende da natureza e da amplitude da política pública em questão. O Estado é agente econômico privilegiado, no sentido de que movimenta quantidade de recursos de enorme relevância e que têm a potencialidade de influenciar de forma decisiva a economia em geral ${ }^{175}$. Cada ato do Estado, incluídos aqueles que visam a implementação das políticas públicas, deve fazer parte de uma coordenação que objetiva a produção dos melhores resultados para a sociedade.

Quando decide, por exemplo, realizar contratações de serviços para construção de escolas públicas, o Estado, além de promover a política pública de educação, influencia diretamente na economia, na medida em que essas contratações geram gasto público, influenciam o nível geral de emprego e o consumo, e promovem uma mudança positiva no longo prazo quanto ao padrão de vida da sociedade, já que a educação é um dos pressupostos para o aumento de produtividade futuro da sociedade e, por conseqüência, o incremento do nível de padrão de vida da população.

A política econômica, quanto aos seus efeitos, tem caráter mais amplo do que as políticas públicas mais setoriais e específicas, no sentido de que seu objetivo é garantir que a economia, como um todo, funcione da forma mais eficiente possível. Nesse sentido, é pressuposto para a viabilização da implementação das políticas públicas. Em outras palavras, a racionalidade da política econômica deve ser a busca por proporcionar uma situação econômica favorável, garantido a possibilidade de concretização das políticas públicas mais específicas.

Quando o Estado decide intervir no mercado de câmbio para impedir, por exemplo, que haja excessiva valorização da moeda nacional frente à moeda estrangeira, proporciona um ganho aos exportadores, que passam a ver a sua receita, em moeda nacional, aumentar. Com maior receita em moeda nacional, os exportadores podem, dependendo de outras circunstâncias macroeconômicas (as quais também dependem de

\footnotetext{
${ }^{175}$ Outras circunstâncias garantem o caráter de agente econômico privilegiado ao Estado, como o fato de não ter um limite definido para o auferimento de receitas, já que obtém a maior parte dos seus recursos da arrecadação tributária, e o fato de não estar sujeito a processos de recuperação ou falência.
} 
decisões de política econômica do Estado), investir na sua atividade produtiva (o que gera uma influência positiva na economia como um todo, pois há um conseqüente aumento do emprego ou investimento em tecnologia, por exemplo) ou mesmo aplicar os recursos no mercado financeiro doméstico, que oferece taxas de retorno altíssimas (e, nesse caso, sem produzir os mesmos efeitos positivos para a sociedade). As ações do Estado produzem efeitos práticos na realidade social. Cabe ao Poder Público garantir que essas ações sejam coordenadas e direcionadas para a consecução dos fins que melhor aproveitem a sociedade.

Dissemos que o objetivo da política econômica deve ser a busca da situação econômica mais favorável. Situação econômica mais favorável significa aquela em que, dadas as limitações de recursos da sociedade, privilegie a consecução dos objetivos eleitos previstos na ordem jurídica, em prol da sociedade como um todo, e, de forma mediata, o desenvolvimento, em virtude do caráter de transformação positiva que ele implica A verificação da melhor situação econômica extrapola meros aspectos quantitativos de crescimento econômico, para englobar uma transformação ampla, que implica melhor distribuição dos recursos disponíveis e a sua alocação em despesas que possam reverter para a promoção do bem-estar social ${ }^{176}$.

\section{Os Fins da Política PúbliCA NA CONSTITUIÇÃo DE 1988.}

\subsection{A ORDEM ECONÔMICA NA CONSTITUIÇÃO DE 1988: FUNDAMENTOS,} PRINCÍPIOS E FINS.

A Constituição de 1988 caracteriza-se como constituição dirigente e, nesse sentido, é dotada de potencial transformador, ao impor ao Estado a atuação direcionada à

\footnotetext{
${ }^{176}$ Como observa ANDRÉA QUEIROZ FABRI: “(...) a política econômica do desenvolvimento deve abranger vários aspectos da economia, o que descarta políticas unilaterais, voltadas somente para conter a inflação. Lamentavelmente, é comum notar a redução da política econômica a mera política monetária nos países em desenvolvimento devido à vinculação das economias nacionais às moedas fortes. Os planos, nesse caso, passam a conter unicamente metas quantitativas, que acarretam a miséria de grande parte da população global, prejudicando, inúmeras vezes, o objetivo do desenvolvimento" (op. cit, p. 12). No mesmo sentido, FÁBIO KONDER COMPARATO chama a atenção que "uma política de estabilidade monetária fundada na prática de juros bancários extorsivos e na sobrevalorização do câmbio, pode-se revelar, de modo geral, incompatível com os fundamentos constitucionais de toda a ordem econômica, quais sejam a valorização do trabalho humano e a exigência de se assegurar a todos uma existência digna" (Ensaio sobre o Juízo de Constitucionalidade de Políticas Públicas, p. 60).
} 
concreção dos fins determinados como prioritários no texto constitucional. Por meio de normas-objetivo ou standards, estabelece os fins que devem ser buscados pelo Estado Brasileiro ao atuar na economia.

A Constituição deve ser analisada de forma completa, como uma unidade dotada de coerência lógica ${ }^{177}$. Isso significa dizer que, ao tratarmos da disciplina constitucional da ordem econômica e buscar os seus fins, não podemos destacar do texto constitucional os dispositivos que tratam expressamente sobre ela e tratá-los como um núcleo independente; ao contrário, devemos buscar a inserção das regras que regem a ordem econômica na Constituição como um todo, interpretando-a como uma integralidade harmônica. Os objetivos das políticas públicas devem ser verificados, portanto, em conjunto com os fundamentos da ordem jurídica vigente e os princípios gerais que a regem.

Coerentemente com essa constatação, cumpre-nos tratar, em primeiro lugar, ainda que sucintamente, sobre os fundamentos da República, ou seja, as bases sobre as quais a República deve ser construída.

O artigo $1^{\circ}$ da Constituição Federal de 1988 prevê, como fundamentos da República, a soberania, a cidadania, a dignidade da pessoa humana, os valores sociais do trabalho e da livre iniciativa e o pluralismo político. Esses são fundamentos gerais, que devem nortear toda atividade estatal (incluindo quanto à ordem econômica), vinculando-a e subordinando a interpretação das normas constitucionais e infraconstitucionais. A livre iniciativa e a valorização do trabalho são reiterados como fundamentos específicos da ordem econômica (caput do artigo 170).

A livre iniciativa deve ser interpretada em caráter amplo, em sua perspectiva social e não individualista, abrangendo a liberdade titulada pela empresa e pelo trabalho ou seja, a liberdade de atuação dos dois extremos na dicotomia capital $\mathrm{x}$ trabalho, característica das sociedades capitalistas ${ }^{178}$.

A livre iniciativa é desdobramento do direito à liberdade, direito fundamental garantido no caput do artigo $5^{\circ}$ da Carta Magna. Encontra, ainda, na própria

\footnotetext{
177 Como alerta ERos RoBerto GRAU, "[n]ão se interpreta a Constituição em tiras, aos pedaços" (A Ordem Econômica na Constituição de 1988 (interpretação e crítica), p. 166).

${ }^{178}$ Eros Roberto GraU, A Ordem Econômica na Constituição de 1988 (interpretação e crítica), pp. 201207.
} 
Constituição, como corolários, a garantia da propriedade privada prevista no inciso XXII do artigo $5^{\circ}$ e no inciso II do artigo 170, a liberdade de iniciativa econômica ou liberdade de empresa que se encontra no parágrafo único do artigo 170, e a livre concorrência, no inciso IV do artigo 170. A livre concorrência deve ser entendida, nesse sentido, como garantia de um processo de competitividade entre os agentes econômicos.

A liberdade de iniciativa impõe ao Estado uma atitude positiva, no sentido de combater atos que possam ameaçar o seu exercício pleno, como a concentração do poder econômico. Determina, por outro lado, uma atitude negativa ao Estado, pois deve se abster de intervir excessivamente na economia e, dessa forma, criar empecilhos ao desenvolvimento de atividades econômicas pelos particulares, como, por exemplo, a imposição de excessiva burocracia para as microempresas.

Dentro da ordem constitucional vigente, a valorização do trabalho encontra concreção nos direitos expressamente elencados nos incisos do artigo $7^{\circ}$ da Carta Magna, bem como em outros que possam a vir a melhorar a condição social dos trabalhadores, conforme o disposto no caput daquele mesmo artigo. Nas sociedades capitalistas, o trabalho ganha especial destaque em razão do papel essencial desse fator de produção para o funcionamento do sistema.

Os objetivos fundamentais gerais da ordem jurídica vigente estão estabelecidos no artigo $3^{\circ}$ da Constituição Federal de 1988, quais sejam, a construção de uma sociedade livre, justa e solidária, a garantia do desenvolvimento nacional, a erradicação da pobreza e a marginalização e redução das desigualdades sociais e regionais e a promoção do bem de todos, sem preconceitos de origem, raça, sexo, cor, idade e quaisquer outras formas de discriminação. O caput do artigo 170 prevê expressamente que o fim da ordem econômica é assegurar a todos existência digna, conforme os ditames da justiça social.

Por certo, uma interpretação harmônica da Constituição Federal impõe a toda atuação do Estado - inclusive na economia e especificamente quanto ao câmbio - o objetivo final de cumprir os objetivos determinados no artigo $3^{\circ}$ e no caput do artigo 170.

A construção de uma sociedade livre, justa e solidária significa, em um primeiro momento, que a liberdade, em seu sentido mais amplo e que já é apresentada como fundamento da República e da ordem econômica na forma da livre iniciativa, deve 
ser buscada. Procura-se a liberdade real, que iguala as pessoas na vida prática e com respeito às suas particularidades, e não apenas liberdade formal. Da mesma forma, a realização de justiça social e a solidariedade entre as pessoas devem orientar as decisões públicas $^{179}$.

O desenvolvimento nacional, por englobar um profundo processo de transformação da vida social em todas as suas esferas, incluindo econômica, política e cultural, sintetiza os demais objetivos eleitos na Constituição. Pela sua relevância e amplitude, trataremos dele em separado a seguir.

A erradicação da pobreza e da marginalização e redução das desigualdades sociais e regionais, além de objetivo fundamental da República, é princípio da ordem econômica (inciso VII do artigo 170). A Constituição Federal reconhece, assim, a realidade brasileira de subdesenvolvimento e da desigualdade na repartição das rendas, e determina como finalidade da ordem a sua superação.

A ordem econômica, sem prejuízo dos demais objetivos fixados pela Carta Magna, tem como fim específico assegurar a todos existência digna, conforme os ditames da justiça social. Esse é um desafio de imensas proporções se considerarmos que o capitalismo, em sua essência, pressupõe a desigualdade, ainda mais nos países periféricos.

A dignidade da pessoa humana é, além de fim da ordem econômica, fundamento da República (inciso III do artigo $1^{\circ}$ ). De acordo com CANOTILHo, "a dignidade da pessoa humana como base da República significa, sem transcendências ou metafísicas, o reconhecimento do homo noumenon, ou seja, do indivíduo como limite e fundamento do domínio político da República. Nesse sentido, a República é uma organização política que serve o homem, não é o homem que serve os aparelhos políticoorganizatórios" $" 180$.

\footnotetext{
${ }^{179}$ EROS RoBERTO GrAU, ao analisar o inciso I do artigo $3^{\circ}$ da Constituição, ensina que "sociedade justa é aquela, na direção do que aponta o texto constitucional, que realiza justiça social (...). Solidária, a sociedade que não inimiza os homens entre si, que se realiza no retorno, tanto quanto historicamente viável, à Geselschaft - a energia que vem da densidade populacional fraternizando e não afastando os homens uns dos outros" (A Ordem Econômica na Constituição de 1988 (interpretação e crítica), p. 215).

${ }^{180}$ Direito Constitucional e Teoria da Constituição, p. 225. CANOTILHO analisa a dignidade humana na Constituição da República Portuguesa, mas suas conclusões são úteis para a compreensão do tema sob a ordem constitucional brasileira.
} 
Especificamente como fim da ordem econômica, a dignidade da pessoa humana deve ser buscada no exercício da atividade econômica pelo Poder Público e por entes privados.

A justiça social confere as balizas necessárias à concretização da dignidade. Nas palavras de EROS ROBERTO GRAU, “justiça social, inicialmente, quer significar superação das injustiças na repartição, a nível pessoal, do produto econômico. Com o passar do tempo, contudo, passa a conotar cuidados, referidos à repartição do produto econômico, não apenas inspirados em razões micro, porém macroeconômicas: as correções na injustiça da repartição deixam de ser apenas uma imposição ética, passando a consubstanciar exigência de qualquer política econômica capitalista"181 . A justiça social implica, portanto, na visão do autor, a superação das desigualdades.

MANOEl GonÇAlves FerReIRA FILHO chama a atenção que a expressão "justiça social" não tem sentido unívoco, mas que, na ordem econômica prevista na Constituição vigente, deve ser entendida como "a virtude que ordena para o bem comum todos os atos humanos exteriores", significando que a ordem econômica deve ser orientada para o bem comum ${ }^{182}$.

Independentemente da dificuldade em que esbarramos ao tentar aprofundar o sentido da "existência digna" e da "justiça social", parece-nos que está implícita na determinação constitucional a orientação da vida econômica de forma a propiciar a repartição das riquezas do País entre as pessoas de forma equânime, para garantir, pelo menos, a satisfação das necessidades básicas do ser humano, como alimentação, moradia, trabalho e educação.

Nos incisos do artigo 170 da Carta Magna estão elencados os princípios que devem nortear a ordem econômica. São eles a soberania nacional, a propriedade privada, a função social da propriedade, a livre concorrência, a defesa do consumidor, a defesa do meio ambiente, a redução das desigualdades regionais e sociais, a busca do pleno emprego e o tratamento favorecido para as empresas de pequeno porte constituídas sob as leis brasileiras e que tenham sua sede e administração no País.

\footnotetext{
${ }^{181}$ Eros Roberto GraU, A Ordem Econômica na Constituição de 1988 (interpretação e crítica), p. 224.

${ }^{182}$ Curso de Direito Constitucional, pp. 359-360.
} 
No que se refere à matéria cambial, a soberania destaca-se como princípio de extrema relevância, a ditar que, no plano da economia, os interesses nacionais se sobrepõem a eventuais interesses estrangeiros. As decisões do Estado na economia, inclusive no que se refere ao câmbio, devem ser tomadas com independência e estar pautadas pela busca dos interesses nacionais.

Como adverte MANOel GonçAlves Ferreira Filho, a integração da economia local com as demais economias do mundo torna difícil o seu desenvolvimento de forma totalmente independente, ainda mais em se tratando de países periféricos ${ }^{183}$. Essa dificuldade se torna mais evidente quando levamos em consideração o atual contexto de globalização financeira. Em verdade, a Constituição não determina o isolamento, mas uma efetiva autodeterminação na condução da política econômica, consubstanciada na ruptura com a dependência e subordinação a interesses externos que muitas vezes permeiam as decisões políticas nos países periféricos ${ }^{184}$.

EROS ROBERTo GraU sustenta que os princípios elencados no artigo 170 consubstanciam instrumentos para a realização do fim de assegurar a todos existência digna, bem como constituem, eles mesmos, fins específicos a serem alcançados e, portanto, justificam a reivindicação de políticas públicas ${ }^{185}$.

Já LUÍS ROBERTO BARROSO agrupa-os em dois grupos, “conforme se trate de princípios de funcionamento da ordem econômica e de princípios-fins. Em linhas gerais, os princípios de funcionamento estabelecem os parâmetros de convivência básicos que os agentes da ordem econômica deverão observar. Os princípios-fins, por sua vez, descrevem realidades materiais que o constituinte deseja sejam alcançadas" ${ }^{\prime 86}$.

Os princípios de funcionamento da ordem econômica seriam aqueles elencados nos incisos I a VI do artigo 170: a soberania nacional, a propriedade privada, a função social da propriedade, a livre concorrência, a defesa do consumidor e a defesa do meio ambiente. $\mathrm{Na}$ opinião do autor, esses princípios limitam e vinculam a conduta dos

\footnotetext{
${ }^{183}$ Curso de Direito Constitucional, p. 362.

${ }^{184}$ Como menciona o professor GILBERTO BERCOVICI, ao discutir a necessidade de fortalecimento do papel do Estado para a promoção de uma política nacional de desenvolvimento, "[a] opção do Brasil não é se integrar na globalização ou se isolar de modo autárquico. A questão fundamental é se a integração dar-se-á a partir dos objetivos nacionais ou não" (Planejamento e políticas públicas: por uma nova compreensão do papel do Estado, p. 161).

${ }^{185}$ A Ordem Econômica na Constituição de 1988 (interpretação e crítica), p. 225.

${ }^{186}$ Ob. cit., pp. 8-15.
} 
particulares e do Estado quando age como empresário. Ao Poder Público compete, ainda, regulamentar o que for necessário para sua implementação.

Os princípios-fins seriam aqueles previstos no caput do artigo 170, bem como nos seus incisos VII, VIII e IX, quais sejam, a existência digna para todos, a redução das desigualdades regionais e sociais, a busca do pleno emprego e o tratamento favorecido para as empresas de pequeno porte constituídas sob as leis brasileiras e que tenham sua sede e administração no País. Os princípios-fins representam os objetivos sociais do Estado na ordem econômica, e devem informar a política econômica para realização dos preceitos constitucionais.

Na visão de Luís ROBERTO BARROSO, portanto, o papel do Estado varia na implementação dos princípios do artigo 170, dependendo se se trata de princípio de funcionamento ou princípio-fim. Os princípios de funcionamento seriam destinados especialmente aos agentes privados. O Estado deveria fiscalizar o regular cumprimento deles pela iniciativa privada, através da edição de regras, fiscalização e imposição de sanções em caso de descumprimento. Já os princípios-fins devem nortear a política econômica estatal. Dessa forma, o Estado deve estabelecer programas para a sua implementação, e criar mecanismos de estímulo à participação da iniciativa privada na consecução desses fins. Esses últimos princípios (princípios-fins) determinariam o objeto das políticas públicas.

9.2.

O DESENVOLVIMENTO NACIONAL COMO SÍNTESE.

A garantia do desenvolvimento nacional é, de acordo com a Constituição Federal de 1988, um dos objetivos fundamentais do País (artigo $3^{\circ}$, inciso II). Apesar de não estar expressamente previsto no título constitucional relativo à ordem econômica e financeira como objetivo específico, não resta dúvida que tal objetivo deve nortear toda a atividade do Poder Público, inclusive no que se refere à ordem econômica ${ }^{187}$.

${ }^{187}$ MANOEL GONÇALVES FERREIRA FILHO entende que o desenvolvimento econômico estaria enfocado na "redução das desigualdades regionais e sociais", prevista como princípio da ordem econômica no inciso VII do artigo 170 da Carta Magna (Curso de Direito Constitucional, p. 360). 
MANOEL GONÇALVES FERREIRA FilHo chama a atenção que o desenvolvimento econômico não é um fim em si mesmo, mas um simples meio para o bem-estar geral. O desenvolvimento econômico seria condição da justiça social, já que não seria possível assegurar ao povo vida digna sem que um patamar elevado de produção. $\mathrm{Na}$ opinião do autor, portanto, o desenvolvimento econômico tem caráter instrumental ${ }^{188}$.

A Constituição, no seu artigo $3^{\circ}$, não se limita à referência ao desenvolvimento econômico. Apesar de estar umbilicalmente vinculado a mudanças nos processos produtivos, o desenvolvimento envolve necessariamente transformações sociais mais amplas do que meramente a existência de indicadores econômicos positivos, englobando transformações econômicas, políticas e sociais ${ }^{189}$.

A busca do desenvolvimento passou a ganhar destaque a partir da década de quarenta do século passado, atraindo forte interesse político e tornando-se uma espécie de prioridade universal ${ }^{190}$, pelo menos no discurso, o que culminou com o reconhecimento, pela Assembléia Geral da Organização das Nações Unidas, do direito ao desenvolvimento como direito humano inalienável (Resolução no 41/128, de 04 de dezembro de 1986) ${ }^{191}$ e a imposição aos Estados da responsabilidade pela criação de condições favoráveis à sua realização.

O desenvolvimento não se confunde com o crescimento. Este último traduz um aumento da população e da riqueza, decorrente de fatos exógenos à economia, os quais, uma vez cessados, levam ao retorno da situação anterior. Envolve, pois, uma mudança meramente quantitativa nos indicadores econômicos. Por outro lado, o desenvolvimento pressupõe mudanças estruturais profundas e qualitativas na sociedade, e caracteriza-se

${ }^{188}$ Curso de Direito Constitucional, p. 360.

${ }^{189}$ LUIZ CARLOS BRESSER-PEREIRA, Desenvolvimento e Crise no Brasil, p. 31. O autor chama a atenção para o fato de que a expressão "desenvolvimento econômico" é, muitas vezes, usada como sinônimo de desenvolvimento, o que se explicaria pelo fato de, no processo de desenvolvimento, o aspecto econômico ter caráter predominante.

${ }^{190}$ FÁBIO NUSDEO, Desenvolvimento Econômico - Um retrospecto e algumas perspectivas, p. 11.

${ }^{191}$ Dispõe o Item 1 do Artigo 1 da referida Resolução: "The right to development is an inalienable human right by virtue of which every human person and all peoples are entitled to participate in, contribute to, and enjoy economic, social, cultural and political development, in which all human rights and fundamental freedoms can be fully realized" [tradução livre: "O direito ao desenvolvimento é direito humano inalienável através do qual é garantida a todo ser humano e a todos os povos a prerrogativa de participar, contribuir e usufruir o desenvolvimento econômico, social e cultural, no qual todos os direitos humanos e liberdades fundamentais possam ser plenamente realizados"]. No preâmbulo da Resolução, a Assembléia Geral das Nações Unidas trata o desenvolvimento como um processo econômico, social, cultural e político, que tem por objetivo o aperfeiçoamento constante do bem-estar de toda a população e de todos os indivíduos com base na sua participação ativa, livre e significativa no desenvolvimento e na distribuição justa dos benefícios resultantes. 
como um processo auto-sustentável, na medida em que cada uma das suas fases cria as condições necessárias para a sua continuidade ${ }^{192}$. O mero crescimento econômico, se não for acompanhado de mudanças estruturais, pode implicar um incremento das desigualdades já existentes, sem que haja uma reversão do fruto desse crescimento para o bem-estar da sociedade como um todo. Contudo, na medida em que a melhora do padrão de vida da população está intimamente ligada com o aumento da produtividade, o crescimento econômico é variável necessária (mas não suficiente) para a promoção do desenvolvimento.

Não se confunde, ainda, o desenvolvimento com a modernização. Nesta, existe a assimilação do progresso técnico por uma minoria privilegiada, mas as condições de vida da maior parte da população permanecem inalteradas. A modernização não acarreta uma efetiva transformação social; ao contrário, intensifica o subdesenvolvimento ${ }^{193}$.

Pela extensão e profundidade das mudanças que implica, parece-nos que o desenvolvimento sintetiza os demais objetivos sociais positivadas na Constituição.

BERCOVICI, nesse sentido, leciona que o "próprio fundamento das políticas públicas é a necessidade de concretização de direitos por meio de prestações positivas do Estado, sendo o desenvolvimento nacional a principal política pública, conformando e harmonizando todas as demais. O desenvolvimento econômico e social, com a eliminação das desigualdades, pode ser considerado como a síntese dos objetivos históricos nacionais" $" 194$.

FÁBIO KONDER COMPARATO destaca a relevância do desenvolvimento nacional como política pública, ao afirmar que "é, sem dúvida, a mais importante das 'navegações de longo curso' que possa empreender uma sociedade. É a principal política pública, aquela dotada de maior sentido arquitetônico - para usarmos da expressão tão cara

${ }^{192}$ Desenvolvimento Econômico - Um retrospecto e algumas perspectivas, p. 17. Em sentido semelhante, SCHUMPETER afirma que todo processo de desenvolvimento repousa no desenvolvimento precedente e que cada processo desenvolvimentista cria os pré-requisitos para o seguinte (Teoria do Desenvolvimento Econômico, p. 90).

193 GILBERTO BerCovici, Constituição Econômica e Desenvolvimento. uma leitura a partir da Constituição de 1988, pp. 50-55.

${ }^{194}$ Planejamento e políticas públicas: por uma nova compreensão do papel do Estado, p. 144. Em outra oportunidade, o autor explica que as políticas públicas são sempre programas setoriais. Nas palavras do autor, "analisar o desenvolvimento por meio das políticas públicas só faz sentido se considerarmos o desenvolvimento nacional a principal política pública, conformando e harmonizando todas as demais" (Constituição Econômica e Desenvolvimento: uma leitura a partir da Constituição de 1988, p. 63). 
a Aristóteles na definição da arte política -, pois engloba e harmoniza todas as demais atividades governamentais"

Para os defensores da economia liberal e neoliberal, o desenvolvimento seria um processo gradual que ocorreria de forma espontânea quando as instituições permitissem o máximo de iniciativa individual. O melhor resultado para a sociedade seria obtido pelo máximo aumento de riqueza, sem que com isso fossem levadas em consideração questões redistributivas ${ }^{196}$.

A realidade concreta desmente essa concepção evolucionista do desenvolvimento. De fato, o que se vê, na prática, é que o desenvolvimento é fato excepcional, restrito a alguns povos e limitado a certas áreas geográficas. Mais, ainda, é inevitável reconhecer a necessidade de atuação direcionada à indução do desenvolvimento nas economias capitalistas, papel esse exercido fundamentalmente pelo Estado.

O desenvolvimento, longe de ser o resultado de um processo espontâneo, pressupõe a adoção de políticas públicas direcionadas a esse fim. O Estado assume o papel de agente promotor do desenvolvimento, seja agindo diretamente ou criando as condições necessárias e induzindo os particulares a realizem ou participem do processo.

A atuação do Estado em direção ao desenvolvimento nacional pressupõe o planejamento de médio e longo prazo nesse sentido. De acordo com o artigo 174 da Constituição Federal, o Estado, como agente normativo e regulador da atividade econômica, exercerá, na forma da lei, a função de planejamento (além das funções de fiscalização e incentivo), sendo o planejamento determinante para o setor público e indicativo para o setor privado. O Estado tem, portanto, o dever de planejar.

O planejamento implica racionalização e coordenação de atos, a fim de buscar uma unidade coerente destinada a promover o desenvolvimento nacional. Não configura uma atuação do Estado no ou sobre o processo econômico, mas apenas qualifica qualquer tipo de atuação como encetada sob padrões de racionalidade sistematizada, “caracterizada pela previsão de comportamentos econômicos sociais e futuros, pela

\footnotetext{
${ }^{195}$ A Organização Constitucional da Função Planejadora, p. 78. Mais adiante, o autor parece reconhecer o caráter de síntese do desenvolvimento nacional ao defender que "[o]s objetivos dos programas de ação governamental devem ser englobados na grande política de desenvolvimento nacional, da qual constituem capítulos" (p. 88).

${ }^{196}$ CALIXTO SAlOMÃo Filho, Regulação e Desenvolvimento, p. 30.
} 
formulação explícita de objetivos e pela definição de meios de ação coordenadamente dispostos" $" 197$. É atuação do Estado voltada para o futuro, com vistas à transformação das estruturas sociais e econômicas, mas comprometido com a ideologia constitucional ${ }^{198}$.

A Constituição Federal prevê que as diretrizes e bases do planejamento do desenvolvimento nacional equilibrado serão estabelecidas em lei, bem como que o planejamento incorporará e compatibilizará os planos nacionais e regionais de desenvolvimento $\left(\$ 1^{\circ}\right.$ do artigo 174$)$.

A União é competente para elaborar e executar planos nacionais e regionais de ordenação do território e de desenvolvimento econômico e social (inciso IX do artigo 21). Cabe ao Congresso Nacional, com a sanção do Presidente da República, dispor sobre os planos e programas de desenvolvimento (inciso IV do artigo 48). Cabe, ainda, ao Congresso Nacional, competência exclusiva para apreciar os relatórios sobre a execução dos planos (inciso IX do artigo 49).

BERCOVICI observa que o principal modo de controle da atividade planejadora em relação ao setor público é a vinculação do plano ao orçamento. A implementação do plano é realizada através de investimentos públicos, os quais devem estar devidamente explicitados no orçamento. A execução do plano depende, portanto, de previsão orçamentária ${ }^{199}$.

A Constituição prevê três leis orçamentárias: (i) o plano plurianual. (ii) as diretrizes orçamentárias e (iii) os orçamentos anuais (artigo 165).

A lei que instituir o plano plurianual deve estabelecer, de forma regionalizada, as diretrizes, objetivos e metas da administração pública federal para as

\footnotetext{
${ }^{197}$ EROS ROBERTO GRAU, A Ordem Econômica na Constituição de 1988 (interpretação e crítica), p. 151.

${ }^{198}$ GILBERTO BerCOVICI, Constituição Econômica e Desenvolvimento: uma leitura a partir da Constituição de 1988, pp. 69-86. O autor chama a atenção para as dificuldades criadas para promoção das políticas públicas após a Reforma do Estado Brasileiro realizada entre 1995 e 2002, que foi norteada pela busca de maior eficiência e efetividade do aparelho estatal. No contexto da Reforma, empresas estatais brasileiras foram privatizadas. Foram também criadas agências reguladoras, órgãos independentes, formados por critérios técnicos, que regulam e fiscalizam a prestação dos serviços públicos. Nas palavras do autor: "Com a Reforma do Estado, criaram-se duas áreas distintas de atuação para o Poder Público: de um lado, a Administração Pública centralizada, que formula e planeja as políticas públicas; de outro, os órgãos reguladores (as "agências"), que regulam e fiscalizam a prestação dos serviços públicos. Isto contraria o próprio fundamento das políticas públicas, que é a necessidade de concretização de direitos por meio de prestações positivas do Estado, ou seja, por meio dos serviços públicos. Política pública e serviço público estão interligados, não podem ser separados, sob pena de esvaziarmos o seu significado" (Planejamento $e$ políticas públicas: por uma nova compreensão do papel do Estado, pp. 150-151).

${ }^{199}$ Planejamento e políticas públicas: por uma nova compreensão do papel do Estado, pp. 155-156.
} 
despesas relativas aos programas de duração continuada, enquanto que a lei de diretrizes orçamentárias deve incluir as metas e prioridades da administração pública federal para o exercício financeiro subseqüente. Os planos e programas nacionais, regionais e setoriais devem ser elaborados em consonância com o plano plurianual e apreciados pelo Congresso Nacional ( $\S 1^{\circ}, 2^{\circ}$ e $4^{\circ}$ do artigo 165$)$.

BERCOVICI ressalta que a inexistência de preocupação dos governos pós1988 com o planejamento, o que compromete a viabilidade dos planos plurianuais, e observa que a tendência recente é a redução do plano ao orçamento. A principal função do planejamento, que é fixar as diretrizes para a atuação do Estado e orientar o investimento privado, fica assim comprometida. "A redução do plano ao orçamento é apenas uma forma de coordenar mais racionalmente os gastos públicos, não um verdadeiro planejamento, voltado ao desenvolvimento, ou seja, à transformação das estruturas socioeconômicas"200.

Cabe, ainda, destacar as observações do autor sobre o agravamento da situação acima em decorrência da Lei de Responsabilidade Fiscal (Lei Complementar $\mathbf{n}^{\circ}$ 101, de 04 de maio de 2000). Essa Lei teve por mérito buscar o controle dos gastos públicos. Contudo, a política de equilíbrio orçamentário imposta a todos os entes da Federação, ao criar um regime rígido de cumprimento de metas e estabelecimentos de limites e condições para provocar a geração de superávits, acaba por criar obstáculos ou inviabilizar a implementação de políticas públicas em determinadas circunstâncias. As políticas públicas exigem, por vezes, investimentos sociais que possam ser deficitários ${ }^{201}$.

Vale lembrar a lição de ALIOMAR BALEEIRO, que destaca que a preocupação não deve ser de equilibrar o orçamento "como se este fosse um fim em si mesmo e não simples meio a serviço da prosperidade nacional". Ou seja, "não se trata de equilibrar o orçamento, mas fazer com que este equilibre a economia nacional"202.

No que se refere à relação entre a atuação do Estado no câmbio e o desenvolvimento, deve-se observar que alguns autores defendem a administração, pelo

\footnotetext{
${ }^{200}$ Planejamento e políticas públicas: por uma nova compreensão do papel do Estado, pp. 156-157.

${ }^{201}$ Planejamento e políticas públicas: por uma nova compreensão do papel do Estado, p. 157.

202 Uma Introdução à Ciência das Finanças, p. 428. RICARDO LOBO TORRES, ao tratar do equilíbrio orçamentário, explica que "é a equalização de receitas e de gastos, harmonia entre capacidade contributiva e legalidade, redistribuição de rendas e transparência orçamentária, desenvolvimento econômico e universalidade. O desequilíbrio orçamentário é sempre o resultado de contradição entre os princípios constitucionais do Estado de Direito. O orçamento não se desequilibra pela falta de dinheiro, mas pelo desencontro entre valores e princípios jurídicos" (O Orçamento na Constituição, p. 211).
} 
Estado, da taxa de câmbio com o objetivo deliberado de promover o crescimento econômico e, dessa forma, proporcionar uma das condições do desenvolvimento.

PAUlo GALA ${ }^{203}$ defende que a manutenção de uma taxa de câmbio depreciada pode, em determinadas circunstâncias e em conjunto com outras variáveis macroeconômicas, ser importante fator a propiciar o crescimento econômico. A administração, pelas autoridades monetárias, da taxa de câmbio no sentido de evitar uma sobrevalorização excessiva teria o condão de contribuir para o desenvolvimento de uma indústria de manufatura voltada para a exportação.

No mesmo sentido, LUIZ CARLOS BRESSER-PEREIRA ressalta que cabe ao Estado, no exercício da política econômica, o papel de administrar a taxa de juros e a taxa de câmbio, visando não apenas a estabilidade macroeconômica, mas o desenvolvimento econômico, "porque uma taxa de juros moderada e uma taxa de câmbio competitiva são dois instrumentos fundamentais para aumentar a taxa de investimento e de poupança do país”. Defende, por conseguinte, que o formulador da política econômica deve buscar uma taxa próxima à de "equilíbrio industrial", assim considerada aquela que permita que as empresas que utilizem tecnologia sejam competitivas sem qualquer proteção tarifária ${ }^{204}$.

Uma política de manutenção da taxa de câmbio sobrevalorizada, comum em situações de populismo econômico, permite o aumento de salários reais sem que ocorram mudanças estruturais efetivas e adequadas na economia. Esse tipo de política acarreta um aumento da demanda especialmente de bens importados, sem que haja um correspondente aumento da capacidade produtiva. Como não há aumento de produtividade, o acréscimo de consumo é financiado por endividamento externo, com sucessivos déficits comerciais e agravamento das contas externas gerando, potencialmente, uma crise no balanço de pagamentos. No longo prazo, a perda de bem-estar acaba por superar os ganhos obtidos no curto prazo com a política de sobrevalorização do câmbio. "O esgotamento das reservas

\footnotetext{
${ }^{203}$ Política Cambial e Macroeconomia do Desenvolvimento.

${ }^{204}$ Tendência à Sobreapreciação da Taxa de Câmbio e Desenvolvimento Sustentando no Brasil, p. 4 e 9. O autor destaca, ainda, a importância do planejamento e da distribuição de renda para o desenvolvimento no seguinte trecho: “(...) o desenvolvimento econômico só ocorre de acordo com o potencial real do país se houver uma estratégia nacional de desenvolvimento que, além de manter as contas do Estado (fiscais) e as contas da Nação (corrente) equilibradas intertemporalmente, for capaz de manter a taxa de juros em um nível moderado e a taxa de câmbio não sobreapreciada mas competitiva. (...) E [essa estratégia] terá que incluir, também, o problema da distribuição da renda." (p. 10)
} 
cambiais e a incapacidade de financiamento do setor público resultam em crises de balanço de pagamentos, insolvência fiscal e aceleração inflacionária" ${ }^{205}$.

Os casos da chamada Doença Holandesa ("Dutch Disease") são apontados como paradigmáticos na demonstração do impacto negativo das sobrevalorizações das taxas de câmbio. O termo "Doença Holandesa" foi criado para designar situações em que é vivenciado o impacto negativo decorrente das rendas econômicas geradas pela abundância de recursos naturais e teve como referência o descobrimento, nos anos de 1960 e 1970, de grandes reservas de gás na Holanda. Naquela ocasião, o acréscimo repentino nas exportações de gás causou excessiva apreciação da moeda holandesa, o que implicou a retração do setor de bens comercializáveis manufatureiro, ocasionando desemprego e menores taxas de crescimento. Paradoxalmente, portanto, a descoberta de abundantes recursos naturais acabou por piorar a situação econômica do País ${ }^{206}$.

Os casos de Doença Holandesa demonstram que a apreciação cambial excessiva (que decorre do maior fluxo de divisas resultante do acréscimo de exportações e do aumento do preço dos bens não comercializáveis por conta do aumento de demanda interna gerada pelos ganhos de renda no setor de recursos naturais) dificulta a produção de bens comercializáveis agrícolas e manufaturados, os quais teriam maior potencial de ganhos de produtividade. A atuação do Estado no sentido de corrigir as distorções decorrentes da apreciação cambial excessiva poderia minimizar ou mesmo neutralizar os seus efeitos, e proporcionar maior benefício para a sociedade com as rendas auferidas repentinamente.

GuSTAVo H. B. Franco, por outro lado, chama a atenção que o crescimento da produtividade, em vez de advir do câmbio depreciado, deveria ser resultado de um aumento da eficiência, "cujo caminho pode parecer mais longo, mas tem sobre o outro a vantagem de produzir competitividade simultaneamente a aumento de salário"207.

Feitas essas breves considerações sobre os fundamentos, princípios e fins da ordem econômica, especialmente sobre o desenvolvimento, não podemos deixar de

\footnotetext{
${ }^{205}$ PAULO GALA, ob. cit., p. 19.

${ }^{206}$ Situação semelhante à da Holanda no episódio retratado foi identificada no caso do grande fluxo de ouro para a Espanha no século XVI devido às descobertas na América.

${ }^{207}$ Crônicas da convergência: ensaios sobre temas já não tão polêmicos, p. 335.
} 
destacar a fluidez com que esses temas são abordados e a dificuldade de se exigir, do Estado, a atuação direcionada à consecução dos fins determinados na Constituição Federal.

$\mathrm{Na}$ prática, ao se verificar a realidade concreta, o que se constata é a incapacidade do Estado de promover a concretização dos fins da ordem econômica. Os fundamentos, princípios e fins constitucionalmente previstos são utilizados para legitimar o discurso estatal, mas, em realidade, fica patente a incompetência do Poder Público em promover uma real mudança na sociedade. Por outro lado, os instrumentos jurídicos disponíveis parecem insuficientes para que se exija do Poder Público uma atuação direcionada à consecução dos objetivos constitucionalmente previstos.

FÁBIO KONDER COMPARATO chama a atenção para a falta de aplicabilidade da declaração de princípios da ordem constitucional constante do artigo 170 da Constituição seja pela dificuldade e falta de tradição do Judiciário brasileiro de extrair conclusões concretas ou criar soluções novas a partir da declaração legal de princípios seja pela inexistência de remédio judicial específico para o caso de ausência de políticas públicas, as quais são necessárias para a consecução de certas finalidades econômicas. Conclui o professor ${ }^{208}$ :

"O que salta aos olhos, logo à primeira leitura do texto constitucional de 1988, é a ineficiência prática da maior parte das disposições nele contidas. Os políticos brasileiros partilham com os latino-americanos, em geral, da conviç̧ão de que os problemas sociais e econômicos resolvem-se, automaticamente, pela $\underline{\text { simples edição de normas; de que o Direito tem uma eficiência in se e per se, }}$ independente dos processos políticos e administrativos indispensáveis à sua plena aplicação na realidade. Nada mais estranho à cultura jurídica latino-americana que a preocupação contemporânea com as estratégias de implementação das normas jurídicas.

Sem dúvida, a consagração, no texto constitucional, das modernas técnicas de solução ao problema da inconstitucionalidade por omissão representou um louvável progresso. Mas é preciso reconhecer que o mandado de injunção, tal como concebido no art. $5^{\circ}$, LXXI da Constituição, é um remédio jurídico inteiramente inadequado para impor a aplicação de políticas públicas ou programas de ação, pois ele serve, tão-só, como instrumento judicial para resolver o problema da carência regulamentar das normas constitucionais. No campo da atividade

\footnotetext{
${ }^{208}$ Ordem Econômica na Constituição Brasileira de 1988, pp. 264-265 e 275.
} 
empresarial, em particular, é óbvio que não há solução jurídica que valha por si mesma, dispensando a aplicação de uma estratégia pública, destinada a revigorar a capacidade produtiva nacional.

Ora, a elaboração, aplicação e execução de políticas públicas - assim como de políticas privadas no nível empresarial - supõe o concurso de pessoal altamente qualificado, e um quadro institucional adequado ao desenvolvimento dessa ação planejadora. O Brasil vem contando, ultimamente, com administradores de empresas de bom nível, em todos os setores. Mas a deficiência na formação de governantes e administradores públicos cresce sem cessar, com o incremento das necessidades públicas.

A função social da ordem jurídica não é, evidentemente, a de suprir a ausência de políticas públicas e, sim, a de criar as condições institucionais para que elas se desenvolvam eficazmente. Essas condições institucionais, no campo da ordem econômica, dizem respeito à organização dos Poderes Públicos e da atividade privada." (grifamos)

Destaca-se, quanto a esse assunto, ementa de decisão do Supremo Tribunal Federal (STF) em que se manifestou sobre o dever dos Municípios de garantir o acesso de crianças a educação e, ao fazê-lo, destacou (i) que, em se tratando de direitos fundamentais, não cabe a avaliação discricionária da Administração; (ii) a possibilidade de o Poder Judiciário determinar a implementação de políticas públicas nos casos em que o Poder Público é omisso, especialmente se as políticas públicas estão positivadas na Constituição Federal ${ }^{209}$ :

"E M E N T A: RECURSO EXTRAORDINÁRIO - CRIANÇA DE ATÉ SEIS ANOS DE IDADE - ATENDIMENTO EM CRECHE E EM PRÉ-ESCOLA EDUCAÇÃO INFANTIL - DIREITO ASSEGURADO PELO PRÓPRIO TEXTO CONSTITUCIONAL (CF, ART. 208, IV) - COMPREENSÃO GLOBAL DO DIREITO CONSTITUCIONAL À EDUCAÇÃO - DEVER JURÍDICO CUJA EXECUÇÃO SE IMPÕE AO PODER PÚBLICO, NOTADAMENTE AO MUNICIIPIO (CF, ART. 211, § $\left.2^{\circ}\right)$ - RECURSO IMPROVIDO.

A educação infantil representa prerrogativa constitucional indisponível, que, deferida às crianças, a estas assegura, para efeito de seu desenvolvimento integral, e como primeira etapa do processo de educação básica, o atendimento em creche e

\footnotetext{
${ }^{209}$ Agravo Regimental no Recurso Extraordinário ${ }^{\circ}$ 410.715, $2^{\text {a }}$ Turma, r. o Ministro Celso de Mello, j. 22.11.2005. Em sentido semelhante, decisões no Recurso Extraordinário n ${ }^{\circ}$ 436.996/SP, r. o Ministro Celso de Mello, j. 26.10.2005, na Medida Cautelar em Argüição de Descumprimento de Preceito Fundamental n ${ }^{\circ}$ 45/MC/DF, r. o Ministro Celso de Mello, j. 29.04.2004, e no Recurso Extraordinário n ${ }^{\circ} 401.673 / \mathrm{SP}$, r. o Ministro Marco Aurélio, j. 26.03.2004.
} 
o acesso à pré-escola (CF, art. 208, IV). (...) A educação infantil, por qualificar-se como direito fundamental de toda criança, não se expõe, em seu processo de concretização, a avaliações meramente discricionárias da Administração Pública, nem se subordina a razões de puro pragmatismo governamental. Os Municípios que atuarão, prioritariamente, no ensino fundamental e na educação infantil (CF, art. $211, \S 2^{\circ}$ ) - não poderão demitir-se do mandato constitucional, juridicamente vinculante, que lhes foi outorgado pelo art. 208, IV, da Lei Fundamental da República, e que representa fator de limitação da discricionariedade políticoadministrativa dos entes municipais, cujas opções, tratando-se do atendimento das crianças em creche (CF, art. 208, IV), não podem ser exercidas de modo a comprometer, com apoio em juízo de simples conveniência ou de mera oportunidade, a eficácia desse direito básico de índole social. Embora resida, primariamente, nos Poderes Legislativo e Executivo, a prerrogativa de formular e executar políticas públicas, revela-se possível, no entanto, ao Poder Judiciário, determinar, ainda que em bases excepcionais, especialmente nas hipóteses de políticas públicas definidas pela própria Constituição, sejam estas implementadas pelos órgãos estatais inadimplentes, cuja omissão - por importar em descumprimento dos encargos político-jurídicos que sobre eles incidem em caráter mandatório - mostra-se apta a comprometer a eficácia e a integridade de direitos sociais e culturais impregnados de estatura constitucional. A questão pertinente à "reserva do possível" ${ }^{210}$. Doutrina". (grifamos)

\footnotetext{
${ }^{210}$ Em seu voto, o Ministro Celso de Mello destaca que “[o] objetivo perseguido pelo legislador constituinte, em tema de educação infantil, especialmente se reconhecido que a Lei Fundamental da República delineou, nessa matéria, um nítido programa a ser implementado mediante a adoção de políticas públicas conseqüentes e responsáveis - notadamente aquelas que visem a fazer cessar, em favor da infância carente, a injusta situação de exclusão social e de desigual acesso às oportunidades de atendimento em creche e préescola -, traduz meta cuja não-realização qualificar-se-á como uma censurável situação de inconstitucionalidade por omissão imputável ao Poder Público". Sobre a "reserva do possível", o Ministro disserta que "[n]ão se ignora que a realização dos direitos econômicos, sociais e culturais - além de caracterizar-se pela gradualidade de seu processo de concretização -, depende, em grande medida, de um inescapável vínculo financeiro subordinado às possibilidades orçamentárias do Estado, de tal modo que, comprovada, objetivamente, a alegação de incapacidade econômica-financeira de pessoa estatal, desta não se poderá razoavelmente exigir, então, considerada a limitação material referida, a imediata efetivação do comando fundado no texto da Carta Política" (destaques no original).
} 


\section{DISCIPLINA JURÍDICA DO CÂMBIO E POLÍTICAS PÚBLICAS}

SUMÁRIO: 10. Disciplina jurídica do câmbio: histórico; circunstâncias econômicas e políticas. - 10.1. Até a década de 1930. - 10.2. Década de 1930. - 10.3. Décadas de 1940 e 1950. - 10.4. Décadas de 1960 a 1980. 10.5. A partir da década de 1990. - 11. A desregulamentação cambial. 12. Quadro normativo atual do câmbio. - 12.1. Operações de exportação. - 12.2. Registro de capitais estrangeiros. - 12.3. Adiantamentos sobre contratos de câmbio. - 12.4. Infrações cambiais. - 12.4.1. Prática de operações ilegítimas de câmbio. Jogo sobre o câmbio. - 12.4.2. Compensação privada de créditos e valores. - 12.4.3. Declarações falsas em contrato de câmbio. Classificação incorreta de contrato de câmbio. 12.4.4. Crimes cambiais.

10. DisCIPLINA JURÍDICA DO CÂMBIO: HISTÓRICO; CIRCUNSTÂNCIAS ECONÔMICAS E POLÍTICAS.

\subsection{ATÉ A DÉCADA DE 1930.}

O padrão-ouro era, no século XIX, a regra pelo mundo, e era adotado pelo Brasil como paradigma teórico. Na prática, o que se via era uma dificuldade prática enorme (não só no Brasil, mas em muitos outros países ${ }^{211}$ ) de se garantir a paridade da moeda nacional com o ouro.

${ }^{211}$ MANKIW relata que, nos Estados Unidos da América, de 1880 a 1896, houve uma queda no nível de preços de $23 \%$. A maioria dos agricultores do oeste do país estava endividada; seus credores eram os banqueiros do leste. Com a deflação e o aumento do valor real dos empréstimos, houve um enriquecimento 
Entre as explicações para essa dificuldade, podemos citar a escassez de metal no mercado e o fato de o comércio internacional não garantir uma distribuição equânime de metal entre os países, o que, na condição de país periférico, colocava o Brasil em situação especialmente frágil.

No início do século XX, a economia brasileira estava baseada em um sistema de exportação, concentrado em alguns poucos produtos primários, que variaram ao longo do tempo (açúcar, ouro, borracha e, especialmente, café) $)^{212}$. A economia agroexportadora brasileira era extremamente vulnerável, na medida em que dependia do mercado internacional dos produtos exportados, e as variáveis-chaves do mercado estavam fora do nosso controle. Por outro lado, a exportação de produtos primários convivia com um alto coeficiente de importação, decorrente do mercado interno pouco desenvolvido.

Nas épocas de crise nos países industriais, os preços dos produtos primários sofriam uma forte queda, diminuindo a entrada de divisas no país. O efeito sobre a procura das importações, entretanto, não era imediato, gerando um desequilíbrio inicial no balanço de pagamentos. Além disso, por mais que a crise gerasse uma queda no valor dos produtos importados, essa queda se fazia de forma lenta e provavelmente não na mesma proporção da redução nos preços dos produtos primários. A relação de troca dos produtos se tornava, portanto, pior para o país. Nesse contexto, a manutenção do padrão-ouro exigiria uma reserva altíssima de metal e era praticamente inviável ${ }^{213}$.

dos banqueiros à custa dos agricultores. Os Estados Unidos praticavam o padrão ouro, e os políticos da época viram como solução para a situação dos agricultores a utilização da prata, além do ouro, como lastro para a moeda, o que possibilitaria o aumento da oferta da moeda no mercado e, conseqüentemente, frearia o processo de deflação. O padrão-ouro foi mantido, mas o problema foi equacionado com a descoberta de ouro no Yukon canadense em 1898 e com o ouro das minas da África do Sul (ob. cit., pp. 666-668). De acordo com Gustavo H. B. Franco, entre 1846 e 1906, o Brasil ficou menos de $10 \%$ do tempo no padrão-ouro (Uma Longa Adolescência: fases da história monetária brasileira, p. 7). Explica o autor que "vivemos, portanto, durante todo este século (que termina em 1933, não esquecer), em um estado meio patológico, onde, teoricamente, uma nota de mil réis deveria valer certa quantidade de libras esterlinas, ou de ouro aí embutido, mas essa mesma nota, no mercado, ou seja, na rua, nos bancos ou entre as pessoas, valia menos. Uma explicação poderia ser: 'há papel moeda representativo de mil réis em quantidades grandes demais', ou que havia 'ouro de menos' para determinada quantidade de moeda em circulação. Ou era o Estado emitindo demais, ou o balanço de pagamentos deficitário; o numerador ou o denominador".

${ }^{212}$ De acordo com os dados consolidados da balança comercial brasileira divulgados pela Secretaria de Comércio Exterior do Ministério do Desenvolvimento, Indústria e Comércio Exterior relativos ao período de janeiro a junho de 2008, as exportações de produtos manufaturados corresponderam a 48,5\% do total de exportações. As exportações de produtos básicos representaram 35,3\% e as de semifaturados foram responsáveis por $13,5 \%$. Os demais $2,7 \%$ referiram-se a operações especiais. Os principais produtos exportados no período foram: (i) material de transporte: 13,5\%; (ii) petróleo e combustível: 11,3\%; produtos metalúrgicos: 10\%; (iii) complexo soja: 10\%; (iv) minérios: 7,9\%; (v) carnes: 7,6\%; (vi) químicos: 6,4\%; (vii) máquinas e equipamentos: 5,1\%; (viii) equipamentos elétricos: 3,5\%; (ix) açúcar e álcool: 3,3\%; (x) papel e celulose: $3,1 \%$; e (xi) calçados e couros: $2,4 \%$.

${ }^{213}$ Celso FurTado, Formação econômica do Brasil, pp. 223-231. 
Nos momentos de queda do preço do café no mercado internacional, dois mecanismos foram utilizados para tentar mitigar os efeitos sobre a economia nacional: as desvalorizações cambiais e a política de valorização do cafée ${ }^{214}$.

As desvalorizações cambiais tentavam proteger os lucros em moeda nacional do setor cafeeiro, já que o preço em moeda estrangeira, apesar de mais baixo, seria convertido por substancialmente o mesmo valor em moeda nacional praticado antes da queda de preços. Pelo menos dois efeitos adversos decorriam dessa política. As desvalorizações mascaravam os sinais dados pelo mercado de que havia excesso de oferta do café no mercado internacional e, portanto, os investimentos no setor cafeeiro continuavam se expandindo, reforçando a tendência de superprodução. Além disso, os produtos importados, que eram fundamentais devido à ausência de um parque industrial formado no País capaz de garantir uma oferta mínima de produtos de consumo básicos, ficavam mais caros, gerando perdas para toda a sociedade em um processo chamado por CELso FurTado de "socialização das perdas".

Além das desvalorizações cambiais, adotou-se uma política de valorização do café, através da qual parte da oferta de café seria retida na forma de estoques, pressionando o aumento do preço daquele produto no mercado. A estocagem do café retido foi financiada por empréstimos externos. O problema dessa política era a dificuldade em se arrumar um destino para o café estocado, uma vez que não se podia garantir a sua demanda no futuro. Além disso, também, nesse caso, os sinais de que havia excesso de oferta de café não chegavam aos produtores, que continuam aumentando seus investimentos.

A maior parte desse período foi marcada pela inexistência de controles pelo Estado das operações cambiais. Na década de 1920, a fiscalização da realização de operações cambiais pelos bancos foi iniciada. Com a promulgação da Lei $n^{\circ} 4.182$, de 13 de novembro de 1920, e sua regulamentação pelo Decreto ${ }^{\circ} 14.728$, de 16 de março de 1921, a Inspetoria Geral de Bancos, subordinada ao Ministério da Fazenda, passou a ter o dever de fiscalizar os bancos e casas bancárias, com o fim de coibir o jogo sobre o câmbio, de forma a assegurar a realização apenas das operações legítimas ${ }^{215}$.

\footnotetext{
214 Amaury Patrick Gremaud, Marco Antônio SANDOval de VASCONCEllos e Rudinei TONETO JÚNIOR, ob. cit., pp. 343-362.

${ }^{215}$ A Inspetoria foi posteriormente extinta, e suas atribuições foram transferidas para a Seção de Fiscalização Bancária, do Banco do Brasil. Os bancos e casas bancárias podiam realizar basicamente as mesmas operações (entre elas as operações cambiais); a diferença estava, primordialmente, no capital da instituição,
} 


\subsection{DÉCADA DE 1930.}

O sistema econômico internacional já funcionava de forma precária desde a virada do século XIX para o século XX, e a Primeira Guerra Mundial ajudou a piorá-lo. A partir da década de 1930, a economia internacional sofreu um profundo processo de mudança, caracterizado pela desintegração e ampliação do protecionismo, que teve como marcos a Crise de 1929 e o New Deal, o abandono do padrão-ouro pela Grã Bretanha em 1931, a Revolução Nacional-Socialista na Alemanha, os Planos Qüinqüenais na Rússia e o colapso da Liga das Nações ${ }^{216}$.

No Brasil, a produção do café, sustentada pelas desvalorizações cambiais e pela política de valorização do café, atingiu volumes enormes. A crise internacional, aliada à superprodução do café, levou os preços do café a valores baixíssimos, o que causou uma grave crise do balanço de pagamentos brasileira. O governo brasileiro continuou com a mesma política de desvalorizações cambiais e estocagem do café (chegando a queimar boa parte do estoque entre os anos 30 e 40), mas ficou claro que a economia brasileira agroexportadora, nos moldes antes existentes, não sobreviveria por muito tempo ${ }^{217}$.

Nesse contexto, foram instituídos controles sobre as operações de câmbio, com a finalidade de tentar conter as reservas de divisas do País em um ambiente de clara escassez.

O Decreto $\mathrm{n}^{\circ} 20.451$, de 28 de setembro de 1931, lançado na esteira dos efeitos sentidos pelo País em virtude da quebra generalizada provocada pela Crise de 1929 e que tinha por objetivo atender a "anormalidade da atual situação e à necessidade de centralizar as operações de aquisição cambiária para o fim de evitar especulações danosas aos interesses do País", determinou o monopólio das operações de câmbio de exportação pelo Banco do Brasil, ao prever que as vendas de letras de exportação ou de valores transferidos do estrangeiro deveriam ser realizadas naquele banco.

que era menor no caso das casas bancárias. O Decreto ${ }^{\circ} 14.728 / 1921$ foi revogado por Decreto sem número de 10 de maio de 1991.

${ }^{216}$ KARL POLANYI, ob. cit., p. 39.

217 Amaury Patrick Gremaud, Marco ANTÔNio SANDOVAl de VASCONCEllos e Rudinei TONETO JÚNIOR, ob. cit., pp. 363-387. 
Em 1933, foi editado o Decreto $\mathrm{n}^{\circ} 23.258,19$ de outubro de 1933, que reforçou a fiscalização bancária das operações de câmbio prevista na Lei n ${ }^{\circ} 4.182 / 1920^{218}$. O Decreto veio aprofundar o controle do câmbio, ao determinar que as operações que não transitassem pelas instituições autorizadas a operar em câmbio seriam consideradas operações ilegítimas de câmbio (artigo $1^{\circ}$ ). Também seriam ilegítimas aquelas operações realizadas em moeda nacional por entidades domiciliadas no País, por conta e ordem de entidades brasileiras ou estrangeiras domiciliadas ou residentes no exterior (artigo $2^{\circ}$ ).

O Decreto $n^{\circ} 23.258 / 1933$ proibiu, ainda, a sonegação de cobertura nos valores de exportação, obrigando os exportadores a ingressar a totalidade dos valores recebidos pela exportação de bens e serviços (artigo $3^{\circ}$ ). Visava-se, assim, um fluxo contínuo de divisas para o País, o que evitaria um aprofundamento da crise do balanço de pagamentos. Esse veio a ser um dos pilares do regime cambial brasileiro durante todo o século XX.

Também com o objetivo de proteger as reservas de divisas, previu-se que o aumento de preço de mercadorias importadas para obtenção de coberturas indevidas seria passível de aplicação de penalidades (artigo $3^{\circ}$ ).

Com a ajuda das medidas acima indicadas e a constatação, pelos empresários, das dificuldades enfrentadas pela lavoura cafeeira, os investimentos, anteriormente quase sempre a ela destinados, passaram a ser direcionados para a nascente indústria nacional. O processo de industrialização iniciado na década de 1930 teve por característica um modelo de substituição das importações, na medida em que voltado para o mercado interno e que contou com proteções contra concorrentes externos ${ }^{219}$.

\footnotetext{
${ }^{218}$ Além do Decreto ${ }^{\circ}$ 23.258/1933, foram editados, no mesmo ano, dois outros decretos que mudaram substancialmente a disciplina da moeda no País: o Decreto $\mathrm{n}^{\circ}$ 23.501/1933, que impôs o curso forçado da moeda nacional e sobre o qual discorremos na Seção 1.5 ("Curso legal e curso forçado da moeda nacional"), e o Decreto n ${ }^{\circ} 22.626$, de 07 de abril de 1933 - "Lei de Usura", que impunha um limite às taxas de juros fixadas nos contratos, correspondente ao dobro da taxa legal (que era de $6 \%$ ao ano no Código Civil de 1916), e vedava o anatocismo.

${ }^{219}$ Além dessas medidas, pode-se citar a elevação os tributos incidentes sobre as importações como uma das formas utilizadas para desestimular as importações. Essa política foi utilizada também durante o governo de Juscelino Kubitschek (Amaury Patrick Gremaud, Marco Antônio Sandoval de Vasconcellos e RUDINEI TONETO JÚNIOR, ob. cit., p. 375).
} 


\subsection{DÉCADAS DE 1940 E 1950.}

Em 1944, o Brasil celebrou o Acordo de Bretton Woods ${ }^{220}$ e, com o objetivo de cumprir as determinações do Acordo, o Decreto-lei $\mathrm{n}^{\circ} 9.025$, de 27 de fevereiro de 1946, assegurou, no seu artigo $1^{\circ}$, a liberdade de compra e venda de cambiais e de moedas estrangeiras, devendo ser observadas as instruções baixadas pela Carteira de Câmbio do Banco do Brasil, sob a orientação da Superintendência da Moeda e do Crédito $(\text { SUMOC) })^{221}$.

A Conferência de Bretton Woods, que resultou na celebração do Acordo, teve por objetivo discutir uma nova modelagem para o sistema monetário internacional, sacrificado com o fim da Segunda Guerra Mundial. Prevaleceu, no Acordo, a proposta apresentada por Henry White, secretário de Tesouro dos Estados Unidos, que consagrou um sistema de administração da taxa de câmbio denominado padrão dólar-ouro, que procurou tornar o padrão-ouro mais flexível ${ }^{222}$.

No padrão-ouro, a definição das moedas é feita com relação a uma quantidade fixa de ouro, consagrando um regime de taxas de câmbio fixas com base na cotação do ouro. Esse sistema pressupõe, ainda, a existência de moedas conversíveis em ouro e, por conseqüência, nas outras moedas nacionais, pelas taxas fixadas.

No padrão dólar-ouro, o dólar foi eleito como moeda internacional, a única que manteria a sua conversibilidade com o ouro. As outras moedas nacionais seriam

\footnotetext{
${ }^{220}$ O Acordo de Bretton Woods foi ratificado pelo Brasil através do Decreto-lei n ${ }^{\circ} 8.479$, de 27 de dezembro 1945.

${ }^{221}$ Cabe observar que, anteriormente, o Decreto-lei $\mathrm{n}^{\circ} 1.201$, de 08 de abril de 1939, já previa, no seu artigo $1^{\circ}$, o restabelecimento da liberdade para as operações de câmbio. Esse Decreto-lei restaurou a liberdade de venda das letras de exportação aos bancos habilitados a operar em câmbio.

222 AMAURY PATRICK GREMAUd, MARCo ANTÔNIO SANDOVAl DE VASCONCEllos e Rudinei TONETO JÚNIOR, ob. cit., pp. 511-519. John Maynard Keynes, que representava a Inglaterra na Conferência, propôs a criação de uma União Internacional de Compensação que atuaria como uma espécie de Banco Central dos Bancos Centrais, no qual cada Banco Central nacional teria uma conta para acumular saldos em ouro. Essa proposta foi rechaçada pelos americanos, que temiam tratar-se de um artifício inglês para obter recursos dos países superavitários. A proposta americana previa, além do sistema de padrão dólar-ouro, a criação do Fundo Monetário Internacional (FMI) e do Banco Mundial. O FMI tinha por objetivo principal adotar medidas anti-restritivas para evitar possíveis instabilidades cambiais e garantir a estabilidade financeira e socorrer os países membros no caso de desequilíbrios transitórios no balanço de pagamentos. O Banco Mundial foi constituído para auxiliar na reconstrução dos países devastados pela guerra e, posteriormente, ajudar do desenvolvimento das nações menos desenvolvidas. Alguns anos depois de Bretton Woods, foi celebrado, ainda, o Acordo Geral de Tarifas e Comércio (GATT), com o intuito de reduzir as restrições ao comércio internacional e liberalizar o comércio multilateral.
} 
livremente conversíveis em dólar a uma taxa de câmbio fixa. O dólar tinha, assim, uma paridade com o ouro, e as demais moedas tinham paridade com o dólar.

No sistema de Bretton Woods, quando uma moeda apresentava tendência a se afastar demasiado do dólar, a taxa de câmbio poderia ser ajustada; esse ajustamento que diferenciava esse sistema do padrão-ouro, tornando-o mais flexível - idealmente deveria ser acordado com as demais partes do Acordo.

O Decreto-lei $n^{\circ}$ 9.025/1946, além de estabelecer a liberdade cambial imposta pelo Acordo de Bretton Woods, previu também que o capital estrangeiro deveria ser previamente registrado na Carteira de Câmbio do Banco do Brasil, para que fosse garantido o direito de retorno (até o limite anual de $20 \%$ do capital registrado ${ }^{223}$ ). Os juros e lucros não poderiam ultrapassar $8 \%$ do capital registrado; o valor que excedesse esse limite seria considerado transferência de capital $^{224}$. O Decreto-lei $n^{\circ}$ 9.025/1946 vedou, ainda, a realização de compensação privada de créditos e valores, vedação essa remanesce até os dias de hoje.

A partir da promulgação da Lei $n^{\circ} 1.807$, de 07 de janeiro de $1953^{225}$, foi adotado regime de taxas múltiplas, em que conviviam duas taxas de câmbio: uma fixada pela SUMOC e outra livremente convencionada pelas partes, adotada nas demais operações. O mercado de câmbio foi, dessa forma, dividido em mercado de câmbio de taxa oficial e mercado de câmbio de taxa livre.

Convém lembrar as circunstâncias econômicas que o País vivia na época. O segundo governo de Getúlio Vargas havia se iniciado em 1951 em uma situação de retomada da inflação e desequilíbrio financeiro do setor público.

A situação externa era, em um primeiro momento, favorável em razão do controle das importações e da recuperação do preço do café. Mas as autoridades passaram a ser mais lenientes na concessão das licenças de importação, aumentando de forma

\footnotetext{
${ }^{223}$ A SUMOC poderia aumentar os prazos de retorno do capital estrangeiro, quando as circunstâncias do mercado assim o exigissem, a fim de dar prioridade ao pagamento das importações, à remessa de dividendos que normalmente represente baixa remuneração de capital, às remessas de imigrantes e às de subsistência.

${ }^{224} \mathrm{O}$ Decreto $\mathrm{n}^{\circ} 30.363$, de 03 de janeiro de 1952, tratou sobre o retorno dos investimentos. Além de reiterar os limites previstos no Decreto n ${ }^{\circ}$ 9.025/1946, impôs a Carteira de Câmbio do Banco do Brasil que fizesse a imediata revisão dos registros de capital estrangeiro então existentes para garantir o atendimento desses limites e considerar como capital nacional todos os montantes que os excedessem.

${ }^{225}$ A Lei $\mathrm{n}^{\circ} 1.807 / 1953$ foi regulada pelo Decreto $\mathrm{n}^{\circ} 32.285$, de 19 de fevereiro de 1953 , revogado pelo Decreto $\mathrm{n}^{\circ}$ 42.820, de 16 de dezembro de 1957.
} 
significativa seu volume. Com a eclosão da Guerra da Coréia e o temor de uma Terceira Guerra Mundial, o País quase entrou em colapso cambial em 1952, primeiro ano do segundo governo de Getúlio Vargas.

A modificação na política de câmbio encerrava um período de taxas fixas que vinha desde 1939. O sistema de taxas múltiplas contemplado na Lei $\mathrm{n}^{\circ}$ 1.807/1953 buscava diminuir o desequilíbrio cambial e conter a tendência crescente da inflação no período $^{226}$.

De acordo com os dispositivos da Lei $\mathrm{n}^{\circ} 1.807 / 1953$, o Conselho da SUMOC fixaria as taxas de câmbio resultantes de paridade declarada no FMI para as operações relacionadas $^{227}$ (i) à exportação e à importação de mercadorias, com os respectivos serviços de fretes, seguros e despesas bancárias; (ii) aos serviços governamentais, inclusive os relativos às sociedades de economia mista em que a maioria do capital votante pertencesse ao Poder Público; (iii) aos empréstimos, créditos ou financiamentos de indubitável interesse para a economia nacional ${ }^{228}$, obtidos no exterior e registrados pelo Conselho da $\mathrm{SUMOC}^{229}$; (iv) às remessas de rendimentos dos capitais estrangeiros registrados pelo Conselho da SUMOC, nos casos de investimentos de especial interesse para a economia nacional.

As operações de câmbio relativas a situações que não as previstas acima seriam efetuadas por taxas livremente convencionadas entre as partes, salvo deliberação em contrário do Poder Executivo em caso de excepcional gravidade.

A Lei $n^{\circ} 1.807 / 1953$ previu, ainda, que as operações de câmbio eram privativas de instituições autorizadas a funcionar pelo Poder Público e que tais instituições

\footnotetext{
${ }^{226}$ FAusto Saretta, A Política Econômica no Período 1954/1955: algumas notas, pp. 2-3.

${ }^{227}$ FAUSTO SARETTA explica que, nesse contexto, foi editada a Instrução SUMOC $\mathrm{n}^{\circ} 70$, que previa cinco taxas cambiais diferentes, com ágios diferentes entre elas e que eram diretamente proporcionais em valor à essencialidade do bem ou produto importado. De acordo com o autor, "os ágios arrecadados seriam e foram utilizados nos gastos do governo, embora originalmente tivesse sido proposto que fossem usados para o financiamento à agricultura e a regularização das operações de câmbio" (ob. cit., p. 4).

${ }^{228} \mathrm{O}$ artigo $5^{\circ}$ da Lei dispõe que se consideram investimentos de especial interesse para a economia nacional os que se destinarem (a) à execução de planos, aprovados pelo Poder Público Federal, de aproveitamento econômico de regiões sob condições climáticas desfavoráveis ou áreas menos desenvolvidas; (b) à instalação ou desenvolvimento de serviços de utilidade pública nos setores de energia, comunicações e transportes, desde que realizados dentro de tarifas fixadas pelo Poder Público.

${ }^{229} \mathrm{O}$ artigo $6^{\circ}$ da Lei previa que as transferências relativas a créditos e rendimentos do capital dependiam das possibilidades do balanço de pagamento e não ultrapassariam anualmente as seguintes percentagens do capital registrado pelo Conselho da SUMOC: (a) $8 \%$ (oito por cento) para juros dos créditos; (ii) $10 \%$ (dez por cento) para os rendimentos do capital estrangeiro.
} 
não poderiam manter posições, compradas ou vendidas, acima dos limites fixados, de modo geral, pelo Conselho da SUMOC.

Na segunda metade da década de 1950, o processo de substituição de importações é aprofundado com o Plano de Metas de Juscelino Kubitschek, que busca a implantação de uma estrutura industrial integrada, especialmente o setor produtor de bens de consumo duráveis ${ }^{230}$.

Os principais instrumentos utilizados pelo governo para implementar o Plano de Metas foram os investimentos das empresas estatais, a concessão de crédito com juros baixos e carência longa, uma política de reserva de mercado e a concessão de garantia para obtenção de empréstimos externos.

Buscou-se, ainda, incentivar o investimento externo no País por razões não só financeiras, mas também tecnológicas. A economia brasileira, até então, era quase que exclusivamente dedicada às atividades agroexportadoras e não havia no País a base tecnológica necessária para se iniciar o processo de industrialização, tampouco condições técnicas para se desenvolver, naquele momento, o mínimo necessário a permitir a industrialização integrada pretendida.

Uma das principais medidas adotadas para incentivar o investimento estrangeiro direto foi a edição, pelo Conselho da SUMOC, da Instrução $n^{\circ} 113$, de 17 de janeiro de 1955, que permitia a importação de bens sem cobertura cambial para fins de investimento. A Carteira de Comércio Exterior do Banco do Brasil (CACEX) foi, por meio dessa Instrução, autorizada a emitir licença de importação sem cobertura cambial para investimentos externos no País nos casos em que tivesse elementos de convicção de que não haveria pagamento de divisas correspondentes a essas importações, e mediante demonstração, pelos investidores, de que dispunham dos equipamentos a serem enviados ao País e de que os equipamentos seriam incorporados ao ativo da empresa a atuar no Brasil. A Instrução previa, ainda, a autorização para a CACEX licenciar equipamentos financiados no exterior para importação por empresas brasileiras, desde que atendido critério de essencialidade.

230 Amaury Patrick Gremaud, Marco antônio Sandoval de Vasconcellos e Rudinei Toneto JÚNIOR, ob. cit., pp. 382-385. 
O Plano de Metas teve resultado bastante satisfatório no que se refere às metas que propôs. Foi observado um rápido crescimento do País, com profundas mudanças estruturais na base produtiva. Contudo, o Plano enfrentou um sério problema de financiamento. Diante de uma política fiscal não condizente, os recursos necessários foram obtidos por meio da emissão monetária e com a obtenção de financiamento no exterior, o que ocasionou uma pressão inflacionária e o crescimento da dívida externa. Do ponto de vista social, a fissura foi ainda mais profunda, já que, ao privilegiar o investimento na indústria com tecnologia e capital intensivo e desestimular a agricultura, acabou por aprofundar a concentração de renda no País.

\subsection{DÉCADAS DE 1960 A 1980.}

A década de 1960 começou com uma crise econômica e com um cenário de profunda instabilidade política. A inflação acelerou, chegando a mais de $90 \%$ em $1964^{231}$. Após o golpe militar de 1964, o governo Castelo Branco lançou o Plano de Ação Econômica do Governo - PAEG, com o objetivo de solucionar os problemas econômicos. O PAEG tinha duas linhas de atuação: políticas conjunturais de combate à inflação e reformas estruturais que visavam permitir a criação de condições necessárias ao crescimento econômico.

No contexto das reformas estruturais, foram editadas duas leis de grande relevância para a matéria cambial e que ainda continuam em vigor: a Lei $\mathrm{n}^{\circ} 4.595$, de 31 de dezembro de 1964 (Lei de Reforma Bancária) e a Lei no 4.131, de 03 de setembro de 1962 (Lei do Capital Estrangeiro). Adiante, quando tratarmos do atual quadro normativo do câmbio, será feito maior aprofundamento sobre a estrutura dessas leis.

A Lei $n^{\circ} 4.595 / 1964$ criou o CMN, em substituição ao Conselho da SUMOC, e transformou a SUMOC no BACEN. Procurava-se, assim, fazer com que a política monetária fosse conduzida de forma mais independente ${ }^{232}$. Determinou, essa Lei, a

\footnotetext{
231 Amaury Patrick Gremaud, Marco Antônio SANDOVal de VAsconcellos e Rudinei Toneto JÚNIOR, ob. cit., pp. 388-413.

${ }^{232}$ A SUMOC era vinculada ao Banco do Brasil. Após a reforma introduzida pela Lei ${ }^{\circ}{ }^{\circ} 4.595 / 1964$, o Banco do Brasil permaneceu como agente bancário do governo. A almejada independência para condução da política monetária continuou enfrentando alguns problemas para sua concretização. O BACEN deveria cumprir as normas editadas pelo CMN que, pela sua composição, estava sujeito a pressões políticas. A conta
} 
competência do CMN para disciplinar a política cambial e a competência do BACEN para implementá-la.

A Lei $n^{\circ} 4.131 / 1962^{233}$ previu que os capitais estrangeiros ficavam sujeitos a registro na SUMOC, na moeda de origem (artigo $\left.3^{\circ}\right)^{234}$. Na sistemática prevista na lei, o registro e o pagamento dos respectivos tributos são requisitos necessários para a remessa de recursos ao exterior com relação ao respectivo capital (parágrafo primeiro do artigo $9^{\circ}$ ). Observe-se que já havia previsão, no Decreto-lei n 9.025/1946, de registro do capital estrangeiro na Carteira de Câmbio do Banco do Brasil. Após a criação do BACEN, o registro passou a ser realizado por aquela autarquia.

A Lei $n^{\circ} 4.131 / 1962$ teve o mérito de promover a sistematização do registro dos capitais estrangeiros e trouxe, ainda, diversos outros dispositivos relevantes para a matéria cambial e que ainda continuam em vigor, como (i) a obrigatoriedade de tratamento jurídico idêntico ao capital estrangeiro que investir no País daquele concedido ao capital nacional, sendo vedadas discriminações não previstas em lei (artigo $2^{\circ}$ ); (ii) a previsão de infrações cambiais, como as declarações de informações falsas nos contratos de câmbio e a classificação incorreta dos contratos de câmbio (artigo 23); e (iii) a realização, pela autoridade monetária, de censo dos capitais estrangeiros aplicados no País periodicamente, em colaboração com o Instituto Brasileiro de Geografia e Estatística (artigo 55).

Alguns anos mais tarde, o Decreto-lei $\mathrm{n}^{\circ} 1.060$, de 21 de outubro de 1969, determinou a obrigatoriedade de as pessoas naturais e jurídicas declararem ao BACEN, na forma, limites e condições estabelecidas pelo $\mathrm{CMN}$, os bens e valores que possuírem no exterior, podendo ser exigida a justificação dos recursos empregados na sua aquisição.

movimento, inicialmente criada para possibilitar a transferência de recursos do Banco do Brasil para que o BACEN entrasse em operação, tornou-se uma linha direta de financiamento do Banco do Brasil com o BACEN, possibilitando uma expansão sem limite de suas operações de crédito. Além disso, o orçamento monetário passou a receber diversos gastos de origem fiscal, o que causou grande dificuldade de controle sobre as contas do governo. O BACEN poderia emitir títulos de dívida em nome do Tesouro Nacional e, assim, a dívida pública aumentaria sob a justificativa de controle monetário.

233 A Lei $n^{\circ} 4.131 / 1962$ foi alterada pela Lei $n^{\circ} 4.390$, de 29 de agosto de 1964. No presente trabalho, ao fazermos referência à Lei $\mathrm{n}^{\circ} 4.131 / 1962$, referimos ao texto conforme alterado em 1964. O Decreto $\mathrm{n}^{\circ}$ 53.451, de 20 de janeiro de 1964, regulamentou a Lei $n^{\circ} 4.131 / 1962$, mas foi revogado pela Lei $n^{\circ}$ 4.390/1964. Posteriormente, um novo regulamento - Decreto $n^{\circ} 55.762$, de 17 de fevereiro de 1965, foi editado.

${ }^{234}$ São registráveis, nos termos do referido artigo $3^{\circ}$, “a) os capitais estrangeiros que ingressarem no País sob a forma de investimento direto ou de empréstimo, quer em moeda, quer em bens; b) as remessas feitas para o exterior com o retorno de capitais ou como rendimentos desses capitais, lucros, dividendos, juros, amortizações, bem como as de 'royalties', ou por qualquer outro título que implique transferência de rendimentos para fora do País; c) os reinvestimentos de lucros dos capitais estrangeiros; d) as alterações do valor monetário do capital das empresas procedidas de acordo com a legislação em vigor". 
Essa declaração deveria ser prestada sem prejuízo das declarações já realizadas às autoridades tributárias ${ }^{235}$. Desde 2002, o BACEN vem conduzindo anualmente o levantamento dos capitais brasileiros no exterior. Atualmente, a declaração é regulada pela Resolução CMN nº 3.540, de 28 de fevereiro de 2008.

Impulsionado pela Lei $\mathrm{n}^{\circ} 4.131 / 1962$ e pelas operações de repasse de recursos externos regulamentadas pela Resolução CMN no 63, de 21 de agosto de $1967^{236}$, o endividamento externo cresceu consideravelmente entre o final da década de 60 e o início da década de 70. Esse endividamento decorreu, em grande parte, da grande liquidez existente nos mercados internacionais no período e da ausência de linhas de financiamento a longo prazo no mercado doméstico (com exceção das linhas oficiais). Além disso, vivenciou-se, no período, um aumento nas taxas de juros cobradas no mercado doméstico, as quais foram tabeladas a partir de 1967, concomitantemente a uma queda das taxas praticadas nos mercados internacionais.

As reformas estruturais buscavam, ainda, evitar pressões sobre o balanço de pagamentos. Adotou-se, a partir de 1968, o regime de minidesvalorizações cambiais, de acordo com o qual a variação das taxas de câmbio deveria refletir a diferença entre as taxas de inflação doméstica e externa. Procurou-se, ainda, atrair os capitais estrangeiros para o Brasil.

A década de $70^{237}$ foi um período conturbado para a economia mundial e para o Brasil. Em 1971, o presidente americano Nixon decretou o fim do sistema de Bretton Woods ao romper com a conversibilidade do dólar em relação ao ouro ${ }^{238}$. Em

\footnotetext{
235 Nos termos da Medida Provisória $n^{\mathbf{o}} 2.224$, de 04 de setembro de 2001, o não-fornecimento de informações ao BACEN relativas a capitais brasileiros no exterior, bem como a prestação de informações falsas, incompletas, incorretas ou fora dos prazos e das condições previstas na regulamentação em vigor constituem infrações sujeitas à multa de até R\$250.000,00. A Medida Provisória dispõe, ainda, que são considerados capitais brasileiros no exterior "os valores de qualquer natureza, os ativos em moeda e os bens e direitos detidos fora do território nacional por pessoas físicas ou jurídicas residentes, domiciliadas ou com sede no País, assim conceituadas na legislação tributária".

${ }^{236}$ A Resolução CMN no 63/1967 permitia aos bancos a possibilidade de contratar empréstimos externos no exterior, repassando-os a empresas no País. No repasse, os custos do empréstimo externo, inclusive a variação cambial, são repassados aos mutuários brasileiros pelos bancos captadores.

${ }^{237}$ Sobre o cenário econômico nas décadas de 1970 e 1980, consultamos AMAURY PATRICK GREMAUD, MARCo ANTÔNiO SANDOVAl de VASCONCELlos e Rudinei TONETO JÚNIOR, ob. cit., pp. 414-429, e LUIZ GonZaga Belluzzo e Júlio GoMes de AlmeIDA, Depois da Queda, pp. 9-16.

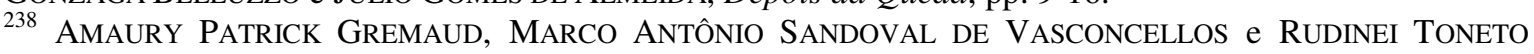
JÚNIOR, ob. cit., p. 519. Os autores explicam a grande contradição entre a prosperidade do comércio internacional e do sistema de dólar-ouro, chamada de "Paradoxo de Triffin", da seguinte forma: "para que a expansão ocorresse, era necessário o crescimento das reservas mundiais em dólares (a fim de não haver crises de liquidez internacional). Essa injeção de liquidez se fazia com base em déficits externos dos EUA; se esses
} 
1973, deu-se o primeiro choque do petróleo, quando os países da Organização dos Países Exportadores de Petróleo - OPEP celebraram acordo sobre o preço do barril do petróleo, elevando consideravelmente seu preço no mercado internacional. O petróleo era uma das matérias-primas fundamentais para a matriz tecnológica, e o efeito desse aumento foi devastador para a economia mundial.

No Brasil, as taxas de inflação, que estiveram controladas desde a segunda metade da década de 60 , voltaram a subir progressivamente. No cenário externo, o balanço de pagamentos apresentou déficits em função não só da alta do preço do petróleo, mas também dos preços dos bens de capital e insumos necessários para manter a produção industrial.

O Brasil vinha do Milagre Econômico e havia grande pressão política para que as altas taxas de crescimento da economia se mantivessem. Os economistas dividiamse entre aqueles que defendiam um ajustamento da demanda interna, o que requeria um controle da liquidez, e aqueles que se posicionavam pela busca de financiamento para proporcionar o crescimento. Apesar de uma sinalização inicial pelo ajustamento, capitaneada pelo Ministro Mário Henrique Simonsen em 1974, acabou-se optando pelo financiamento, ao final de 1974, com o lançamento do Segundo Plano Nacional de Desenvolvimento. Buscava-se alterar a estrutura da indústria brasileira para evitar a necessidade de importação de bens de capital e insumos básicos e fortalecer a base exportadora; enquanto isso não fosse concretizado, o crescimento econômico deveria ser sustentado por financiamentos.

Nesse período, mudou-se o perfil do financiamento na economia brasileira. Enquanto que, na década de 60, a maior parte dos financiamentos externos era obtida pelas empresas privadas, a partir da década de 70 ocorreu um processo de "estatização da dívida externa", com o aumento dos financiamentos obtidos no exterior pelas empresas estatais.

Verificou-se uma restrição ao acesso das empresas estatais ao crédito interno e uma política de contenção tarifária, que empurrou essas empresas ao endividamento externo. As empresas privadas, por sua vez, tiveram acesso a créditos

déficits fossem sistemáticos, e se os ativos em ouro norte-americanos fossem constantes (na verdade eram cadentes), a confiança na conversibilidade do dólar e, por conseqüência, a base dos acordos de Bretton Woods ruiria. Por outro lado, caso não houvesse injeção de liquidez, o crescimento também não ocorreria. Assim, o que se verificou foi um forte crescimento econômico, porém com uma contínua perda de confiança no sistema". 
subsidiados por órgãos estatais, notadamente o Banco Nacional de Desenvolvimento Econômico $^{239}$, cujo volume de recursos disponíveis quase duplicou no período.

Os países que faziam parte da OPEP acumularam grandes superávits com o aumento dos preços do petróleo e, por conta disso e da inviabilidade de aplicação desses recursos exclusivamente nos respectivos mercados domésticos, havia forte disponibilidade de recursos para empréstimo no mercado internacional, em um movimento que foi chamado de "processo de reciclagem de petrodólares". Apesar da liquidez internacional, das taxas de juros baixas e de mecanismos criados para estimular o endividamento externo pelas empresas privadas (como o hedge cambial $^{240}$ ), as captações realizadas pelo setor privado tiveram, em sua maioria, finalidades especulativas.

O Estado assumiu, no âmbito do Segundo Plano Nacional de Desenvolvimento, grande passivo em financiamentos externos. As taxas de juros internacionais estavam baixas e o Estado podia pagar os juros. Mas, como essas taxas eram variáveis, havia enorme vulnerabilidade de deterioração das contas públicas no caso de eventuais mudanças no cenário externo. Essa foi efetivamente a semente dos graves problemas enfrentados pela economia brasileira da década seguinte, e que teve como resultado uma nova "socialização de perdas".

Em 1979, houve o segundo choque do preço do petróleo. As condições de financiamento externo mudaram, com elevação das taxas de juros praticadas no mercado internacional. $\mathrm{O}$ endividamento externo brasileiro era crescente, o que colocava o país em um estado de grande vulnerabilidade. A situação fiscal se deteriorava a passos largos.

Em dezembro de 1979, o cruzeiro foi desvalorizado em 30\%. Houve, ainda, fixação prévia de uma correção cambial em $45 \%$ e correção monetária em $30 \%$ para o ano de 1980. Na prática, as medidas adotadas pelo governo para conter a crise foram ineficazes; a inflação subiu para os $100 \%$ ao ano e as contas externas se deterioraram ainda mais.

\footnotetext{
${ }^{239}$ O banco passou a ser chamar Banco Nacional de Desenvolvimento Econômico e Social - BNDES mais tarde, no Governo Figueiredo.

${ }^{240}$ A Resolução CMN n 432, de 23 de junho de 1977, permita aos mutuários de empréstimos externos a realização de depósitos em moedas estrangeiras em bancos autorizados a operar em câmbio no País dentro dos limites fixados pelo BACEN.
} 
A década de 80 começou com esse quadro de crise. O governo adotou, em 1980, uma política denominada de "ajustamento voluntário", com o objetivo de conter a crise cambial. Buscava-se diminuir a demanda interna que, de acordo com o governo, seria a causa da crise, através da redução dos gastos públicos, do aumento da taxas de juros internas, da restrição do crédito e da redução do salário real. Por outro lado, a estrutura de preços deveria tornar-se mais atrativa ao setor externo, por meio de desvalorizações reais da moeda nacional, elevação dos preços dos derivados do petróleo e estímulos à indústria nacional.

$\mathrm{Na}$ verdade, outros fatores (que não excesso de demanda) colaboraram para a situação de desequilíbrio externo em que a economia se encontrava. Os empréstimos externos captados durante a década de 1970 começavam a ser cobrados e houve um aumento das taxas de juros aplicáveis aos empréstimos (que, como mencionado acima, eram variáveis) e a deterioração dos termos internacionais de troca.

No final da década de 1979, o Banco Central americano adotou uma política monetária restritiva com o objetivo de conter uma tendência de desvalorização do dólar iniciada em 1973. Ronald Reagan assumiu a presidência americana em 1980 e, ao adotar uma política de redução da intervenção estatal na economia defendida pelos liberais da escola de Chicago e refletida na redução da carga tributária, acabou por aprofundar ainda mais as dificuldades fiscais do governo americano. Os Estados Unidos se tornaram o maior absorvedor da liquidez mundial, deixando os países em desenvolvimento praticamente sem acesso a divisas para promover a rolagem das suas dívidas externas.

Diante desse cenário, para tentar pagar os financiamentos externos, o governo brasileiro emitia títulos públicos no mercado doméstico, a juros cada vez maiores e prazos cada vez menores. Esse processo de transformação da dívida externa em dívida interna piorou a situação das contas públicas.

Em geral, pode-se dizer que a década de 80 revelou um quadro de crise profunda, com taxas de crescimento baixas e taxas de inflação altas. O combate à inflação, por meio de planos econômicos que tinham como principal elemento o congelamento de preços, tornou-se a principal meta dos governos. Durante esse período, o País encontrou-se praticamente excluído do fluxo de capitais internacionais. 
Entre o segundo semestre de 1989 e o primeiro semestre de 1990, vigorou situação de centralização cambial no País, a qual foi declarada após decisão dos bancos credores do Brasil de não conceder créditos novos para renegociação da dívida externa. $\mathrm{O}$ pagamento dos juros devidos aos bancos estrangeiros foi suspenso, e os pagamentos ao exterior ficaram sujeitos à análise de prioridade por parte do BACEN e, portanto, deveriam obedecer a uma programação de desembolsos determinada pela autoridade monetária. Todas as operações aguardavam a autorização do BACEN para serem realizadas, e todas as sobras de divisas eram passíveis de serem recolhidas pelo $\mathrm{BACEN}^{241}$.

No cenário internacional, nota-se, a partir da década de 1980, uma intensificação na importância do mercado de capitais frente ao mercado de crédito. Isso se deu especialmente com o crescimento da representatividade dos investidores institucionais (como os fundos de pensão), a internacionalização dos mercados e as inovações financeiras, como a securitização de dívidas e os mecanismos de diminuição de riscos (as operações de derivativos, nos mercados de futuros, opções e swaps ${ }^{242}$. Esse processo é acompanhado por uma política generalizada de liberalização financeira.

Esse novo cenário da economia mundial, que privilegia sobretudo uma integração cada vez maior entre os mercados, trouxe uma nova ordem de preocupações. A principal delas é que a instabilidade em um dado mercado repercute de forma rápida em outros mercados, já que as informações estão disponíveis de forma imediata em qualquer parte do mundo e a liberalização financeira garante a facilidade na mobilidade dos capitais. Como resultado, as economias estão mais vulneráveis e uma crise em um país contagia rapidamente a economia dos demais.

\footnotetext{
241 Álvaro ANTÔNIO ZINI JúNIOR, ob. cit., pp. 20-21.

${ }^{242}$ Sobre as mudanças ocorridas na economia internacional nas décadas de 1980 e 90, consultamos AMAURY PATRICK GREMAUd, MARCo ANTÔNIO SANDOVAl DE VASCONCEllos e RUDinei TONETO Júnior, ob. cit., pp. 523-531. O Fundo Social de Emergência foi instituído pela Emenda Constitucional de Revisão ${ }^{\circ}{ }^{\circ}$, de 01 de março de 1994, para os exercícios de 1994 1995, "com o objetivo de saneamento financeiro da Fazenda Pública Federal e de estabilização econômica" (artigo $1^{\circ}$ ). Os recursos seriam aplicados no custeio das ações dos sistemas de saúde e educação, benefícios previdenciários e auxílios assistenciais de prestação continuada, inclusive liquidação de passivo previdenciário, e outros programas de relevante interesse econômico e social. A Emenda Constitucional $n^{\circ}$ 17, de 22 de novembro de 1997 estendeu o período do Fundo para até o final de 1999.
} 


\subsection{A PARTIR DA DÉCADA DE 1990.}

Em 1993, iniciou-se a implementação de medidas relacionadas ao Plano Real que, ao contrário dos planos econômicos adotados anteriores, previa uma operacionalização gradual e sem congelamentos. Em um primeiro momento, buscou-se promover um ajuste fiscal, principalmente através de corte de gastos concentrado nas despesas de investimento e pessoal, a instituição do Imposto Provisório sobre Movimentação Financeira - IPMF e a aprovação do Fundo Social de Emergência ${ }^{243}$.

Foi criada, em seguida, a Unidade Real de Valor (URV). De acordo com o artigo $1^{\text {o }}$ da Lei $\mathrm{n}^{\circ}$ 8.880, de 27 de maio de 1994 (originária da conversão da Medida Provisória n 482, de 28 de abril de 1994), a URV seria "dotada de curso legal para servir exclusivamente como padrão de valor monetário". Os efetivos pagamentos continuavam a ser realizados em cruzeiro real, que mantinha sua função de meio de pagamento com poder liberatório. A inflação permanecia, assim, em relação ao cruzeiro, mas não em relação à URV.

Em 01 de julho de 1994, foi introduzida a nova moeda - o Real, cujo valor era igual ao da URV (artigo 13 da Lei n 9.069, de 29 de junho de 1995, fruto da conversão da Medida Provisória $n^{\circ}$ 1.027, de 20 de junho de 1995). O Real seria emitido pelo BACEN mediante a prévia vinculação de reservas internacionais em valor equivalente, composta por ativos de liquidez internacional denominados ou conversíveis em dólares norte-americanos, mediante a equivalência de um dólar para cada real emitido (artigo $3^{\circ} \mathrm{e}$ parágrafos).

No que se refere ao câmbio, a Lei no 9.069/1995 determinou que o ingresso e a saída de moeda nacional e estrangeira do País devem ser processados exclusivamente através de transferência bancária, cabendo ao estabelecimento bancário a perfeita identificação do cliente ou do beneficiário, exceto no caso de porte em espécie de valor correspondente a até $\mathrm{R} \$ 10.000,00$ e quando comprovada a entrada ou saída do País na forma da regulamentação pertinente (artigo 65 e parágrafos).

243 Amaury Patrick Gremaud, Marco Antônio Sandoval de Vasconcellos e Rudinei Toneto JÚNIOR, ob. cit., pp. 471-511. 
Quando o Plano Real foi lançado, o volume de reservas internacionais do País era razoável e, com a manutenção da elevada taxa de juros e a existência de considerável liquidez no mercado internacional, o fluxo de capitais externos se manteve. Foi adotado um regime de taxas de câmbio flutuantes e, como conseqüência, houve grande apreciação da moeda nacional. Nesse cenário, as importações passaram a ser bastante atrativas e, devido à concorrência externa, ficou dificultada a propagação de eventuais tentativas de elevações de preços.

Ocorre que o câmbio apreciado e a demanda aquecida levaram ao aparecimento de déficits na balança comercial, causados tanto pelo aumento das importações quanto pela diminuição das exportações. Chama a atenção o fato de que, entre 1994 e 1995, os dois itens que tiveram maior aumento nas importações foram automóveis (208\%) e bens de consumo (185\%), os quais não contribuem para a ampliação da capacidade produtiva do País e, portanto, para a sua capacidade futura de pagamentos. Além disso, a maior parte do capital ingressado nesse período foi destinado a investimentos de portfólio (que se caracteriza pela rapidez com que deixa o País em caso das circunstâncias econômicas deixarem de ser favoráveis), e não a investimentos de longo $\operatorname{prazo}^{244}$.

Em 1994, o governo tentou controlar a apreciação cambial através da adoção de um regime de bandas cambiais e evitar, assim, uma piora ainda maior das contas externas $^{245}$. No final de 1994, com a crise mexicana, grande parte das reservas internacionais do País foram gastas para tentar conter os efeitos da crise. Houve o alargamento das bandas cambiais e desvalorização do câmbio. As taxas de juros internas foram aumentadas com o objetivo de manter a atratividade do mercado brasileiro para os investidores estrangeiros.

A política adotada levou a uma grande retração econômica, que culminou com uma crise no sistema financeiro e a quebra de bancos. No que se refere ao câmbio, o BACEN, para evitar a apreciação da moeda nacional (como tinha ocorrido logo após a implementação do Plano Real, quando as taxas flutuavam livremente), passou a comprar o excesso de divisas ingressado no País, as quais se transformaram em reservas. Para evitar o impacto monetário expansionista, que poderia converte-se em novo surto inflacionário, o

${ }^{244}$ Amaury Patrick Gremaud, Marco Antônio Sandoval de Vasconcellos e Rudinei Toneto JÚNIOR, ob. cit., pp. 482-483.

${ }^{245}$ Sobre o histórico dos regimes cambiais adotados no Brasil, ver a Seção 6.1 ("Regimes Cambiais"). 
governo adotou políticas de esterilização com o conseqüente aumento da dívida pública. Essa política penaliza sobremaneira as contas públicas, em razão da diferença entre a taxa de remuneração das reservas e a taxa de juros paga nos títulos públicos.

Sempre que ocorria alguma situação que colocava em dúvida a capacidade do governo de financiar o déficit em transações correntes - como foi o caso da crise asiática de 1997 e da crise russa de 1998 - a taxa de juros era aumentada. Além disso, os indicadores macroeconômicos mostravam uma deterioração da economia, com aumento de desemprego, queda do Produto Interno Bruto e aumento do déficit público.

Na década de 1990, o perfil do endividamento externo brasileiro mais uma vez se alterou. A participação do setor privado, que representava cerca de $40 \%$ do total do endividamento externo do País em 1994, pulou para 62\% em 1997. Nesse cenário, a grande desvalorização cambial, que viria em 1999, teria por efeito esperado uma grande crise financeira e de consumo no setor privado. Não foi isso, todavia, o que ocorreu.

O setor privado teve, à sua disposição, grande oferta de mecanismos de hedge, como operações no mercado futuro, com moeda estrangeira e outros ativos atrelados a moeda estrangeira, que lhe permitiu proteger-se do risco cambial. Nesse momento, em que quase ninguém acreditava ser possível a sustentação da política cambial do País, foi o setor público que garantiu ao setor privado a possibilidade de livrar-se do risco cambial. Em primeiro lugar, o governo vendeu mais de US\$30 bilhões das reservas do País entre agosto e setembro de 1998. As taxas prefixadas dos títulos públicos foram substituídas por outras que ofereciam proteção mais adequada às oscilações da taxa de câmbio ou mesmo pela variação cambial. Por fim, o governo ainda atuou no mercado futuro vendendo dólares para conter a demanda do setor privado. As perdas da desvalorização cambial de 1999 ficaram concentradas, em sua grande maioria, no setor público $^{246}$.

Em 21 de junho de 1999, foi editado o Decreto $\mathrm{n}^{\mathrm{o}} 3.088$, que estabeleceu, como "diretriz para fixação do regime de política monetária" o sistema de metas de

\footnotetext{
246 De acordo com Amaury PAtrick Gremaud, Marco Antônio SANDOval de Vasconcellos e RUDINEI TONETO JÚNIOR, se considerarmos a diferença das taxas de câmbio pelas quais as reservas foram vendidas em agosto e setembro de 1998 e o valor da taxa de câmbio em janeiro de 1999, a venda de reservas gerou uma perda de aproximadamente $\mathrm{R} \$ 21$ bilhões. Além disso, como a desvalorização da taxa de câmbio em janeiro de 1999 foi em torno de 65\%, o prejuízo para o Tesouro Nacional em decorrência da mudança de indexadores dos títulos públicos foi da ordem de $\mathrm{R} \$ 50$ bilhões (ob. cit., p. 494).
} 
inflação. De acordo com esse Decreto, as metas de inflação e os intervalos de tolerância são fixados pelo CMN, mediante proposta do Ministro da Fazenda, e o BACEN deve executar as políticas necessárias para o cumprimento das metas. Caso a meta não seja cumprida, o Presidente do BACEN deverá divulgar as razões do descumprimento, por meio de carta aberta ao Ministro de Estado da Fazenda.

No sistema de metas de inflação, o objetivo primordial da política monetária é a manutenção da taxa de inflação nas metas estipuladas pelo CMN e, para tanto, o principal instrumento utilizado é a taxa de juros. Quando a taxa de inflação atinge patamar superior à meta, a taxa de juros é elevada. Por outro lado, quando a taxa de inflação é inferior à meta, reduzem-se os juros.

Desde então, toda a política econômica, inclusive a cambial, tem sido operacionalizada de forma a propiciar que as metas de inflação sejam atingidas.

\section{A DESREGULAMENTAÇÃO CAMBIAL.}

A partir do final da década de 1980 e início da década de 1990, iniciou-se um processo que vem sendo comumente chamado de "desregulamentação cambial", "flexibilização cambial" ou, ainda, de "medidas de simplificação na área de câmbio", consistente em uma gradativa diminuição dos controles cambiais através da simplificação das regras editadas pelo BACEN sobre o câmbio e a diminuição das exigências para realização daquelas operações ${ }^{247}$.

Em texto técnico datado de agosto de 2008, o BACEN justifica as mudanças ao esclarecer que "[a] sensível melhora dos fundamentos da economia brasileira e a significativa redução da vulnerabilidade externa do País têm permitido a adoção, nos últimos anos, de significativos aperfeiçoamentos das disposições cambiais na busca da modernização e atualização do mercado de câmbio brasileiro, adequando-o aos

\footnotetext{
247 PÉRSIO ARIDA entende que essa forma de evolução gradativa da regulamentação cambial trouxe conseqüências negativas para o funcionamento do mercado cambial e da economia como um todo, a saber: (i) elevados custos de transação, pois a sobreposição de novas normas criou um quadro regulatório de difícil entendimento; (ii) riscos de natureza legal e/ou regulatória, já que muitas alterações foram empreendidas apenas pela mudança de interpretação pelo BACEN de textos normativos já existentes; (iii) dificuldade de avanços adicionais; e (iv) reversibilidade, já que a maior parte das leis que prevêem os controles cambiais continuam em vigor (op. cit., pp. 4-5).
} 
procedimentos e condições praticados por grande parte dos países que já se encontram com uma economia estabilizada ou em processo de estabilização"248.

Em verdade, diversas explicações ou justificativas têm sido apresentadas para as mudanças que vêm sendo realizadas nas últimas décadas. A principal delas, como se vê do trecho acima transcrito, funda-se em uma melhora dos fundamentos da economia brasileira. Por essa explicação, os controles cambiais haviam sido instituídos em resposta a um cenário de escassez de divisas, que não mais refletiria a realidade brasileira. A existência de um nível de reserva de divisas considerado razoável e a maior solidez da economia nacional, com a diversificação da base exportadora, teria levado a um cenário de maior conforto para um processo de redução dos controles cambiais até, possivelmente, a sua completa eliminação.

Em outro texto, intitulado O Regime Cambial Brasileiro - Evolução Recente e Perspectivas, divulgado pelo em 1993, o BACEN faz um breve histórico do regime cambial brasileiro e destaca o fato de que a rigidez dos controles vigentes no passado incentivou a formação de um mercado dual. De um lado, situava-se o mercado de câmbio oficial, extremamente regulado, e, de outro, um mercado de câmbio paralelo ou negro, nos quais as operações eram realizadas à margem do controle de câmbio do BACEN, e a moeda estrangeira era transacionada com ágio.

Durante a década de 80 , um volume relevante de operações cambiais era realizado no mercado paralelo. A oferta e demanda de moedas estrangeiras transacionadas no mercado paralelo provinham de fontes diversas. Do lado da demanda, investimentos de portfólio de residentes no País em moeda estrangeira, importações contrabandeadas, pagamentos de serviços em geral quando bloqueados no mercado oficial em virtude de lei ou de controles administrativos e repatriação de capitais não registrados no BACEN. Do lado da oferta, as fontes de moeda estrangeira mais relevantes eram o subfaturamento de exportações e o superfaturamento de importações, exportações contrabandeadas, o ingresso de capitais sem registro no BACEN e o recebimento de serviços, especialmente turismo ${ }^{249}$.

Um dos objetivos da "flexibilização" seria trazer para o mercado oficial de câmbio operações cujos recursos teriam origem legítima, mas que não eram cursadas no mercado de câmbio oficial devido às restrições de conversibilidade impostas pela 
regulamentação cambial. Apenas as operações cujos recursos decorressem da prática de atividades ilícitas, como tráfico de drogas, sonegação fiscal, entre outras, seriam empurradas para o mercado paralelo. Essa mudança implica, portanto, uma mudança no foco da supervisão realizada no mercado de câmbio. Os controles cambiais, focados na conversibilidade da moeda, são substituídos por controles que visam apenas a identificação da origem e destino dos recursos, com o objetivo declarado de dar maior transparência às operações cambiais.

A simplificação das regras cambiais almejaria, ainda, a redução dos custos relacionados ao controle das operações cambiais. As exigências para realização das operações cambiais demandavam um controle grande por parte das empresas, dos bancos e do BACEN, o que elevava sobremaneira o custo das operações cambiais. Nesse sentido, por exemplo, a exigência da cobertura cambial de exportações implicava a necessidade da realização de registros por parte das instituições financeiras, além dos registros exigidos para as operações de comércio exterior propriamente ditos, o que aumentava consideravelmente os custos operacionais relacionados a essas operações.

O processo de "flexibilização" tem sido primordialmente implementado por meio da mudança de interpretação, pelo BACEN, de alguns textos normativos da legislação cambial, e pela edição de nova regulamentação pelo CMN e pelo BACEN, no exercício da capacidade normativa de conjuntura. A legislação que trata sobre o câmbio e que foi editada anteriormente ao início do processo de "flexibilização" continua, em sua maior parte, em vigor. $\mathrm{O}$ que tem mudado de forma consistente é a interpretação que vem sendo dada pela autoridade monetária a essa legislação.

O processo de desregulamentação na área cambial vem ao encontro das reformas preconizadas pelo Consenso de Washington ${ }^{250}$.

O termo Consenso de Washington (Washington Consensus) foi utilizado pela primeira vez por JOHN WILLIAMSON, economista do Institute for International Economics, em uma conferência realizada em 1989. O economista fez uma lista de dez políticas que seriam necessárias para a promoção do desenvolvimento na América Latina e sobre as quais haveria certo consenso na capital americana, quais sejam (i) disciplina fiscal; (ii) reorganização das prioridades dos gastos públicos; (iii) reforma tributária; (iv)

${ }^{250}$ Sobre o Consenso de Washington, consultamos JoHn Williamson, A Short History of the Washington Consensus. 
liberalização dos juros; (v) taxas de câmbio competitivas (ou seja, que estejam depreciadas ou corretamente determinadas, mas nunca apreciadas); (vi) abertura comercial; (vii) eliminação de restrições ao ingresso de investimento externo direto; (viii) privatização; (ix) desregulamentação (especialmente com afrouxamento das barreiras a entrada e saída de recursos); e (x) respeito ao direito de propriedade intelectual.

$\mathrm{Na}$ época em que a expressão foi cunhada, as medidas não configuraram propriamente uma novidade, mas ela teve, por mérito, condensar, em um só termo, um conjunto de idéias econômicas que os responsáveis pela política norte-americana concordavam serem necessárias para os países latino-americanos.

O Consenso de Washington é comumente referido como uma pauta de idéias em defesa do neoliberalismo ou fundamentalismo de mercado ${ }^{251}$. Em termos gerais, o neoliberalismo preconiza a capacidade do mercado de promover o melhor resultado econômico e, portanto, defende que o Estado deve participar o mínimo possível no processo econômico. Essa doutrina foi adotada de forma paradigmática no governo de Margaret Thatcher e de Ronaldo Reagan, com a realização de privatizações (principalmente na Inglaterra de Thatcher) e a diminuição dos impostos sobre as camadas mais ricas da população e dos gastos sociais.

Se analisarmos as políticas empreendidas pelo governo brasileiro a partir da década de $1990^{252}$, é inevitável a constatação da influência direta das medidas sintetizadas no Consenso de Washington. Parece-nos, contudo, que a ordem constitucional brasileira não legitima essa postura de não-intervenção estatal. Ao impor a soberania nacional como princípio da ordem econômica, a Constituição Federal determina que os interesses

\footnotetext{
${ }^{251}$ JOHN WILLIAMSON defende que essa interpretação perverte as idéias originais que levaram à reunião das dez medidas do Consenso de Washington. Explica o autor que as políticas tipicamente neoliberais, como o monetarismo e o Estado mínimo, estavam longe de representar um consenso na capital americana (ob. cit., p. 7).

${ }^{252}$ Como exemplo, citamos a promulgação da Lei de Responsabilidade Fiscal (Lei Complementar $n^{\circ}$ 101, de 04 de maio de 2000 - LRF). O critério orientador para formulação da LRF foi a busca do equilíbrio das contas públicas. Para isso, criou-se um regime rígido de cumprimento de metas e estabelecimento de limites e condições, que tem por objetivo a geração de um superávit primário, mesmo que isso ameace o cumprimento, pelo Estado, dos seus deveres. O que pareceu motivar a edição da LRF é o estabelecimento do Estado bom devedor, "lucrativo" o suficiente para que possa pagar sempre em dia seus credores externos. A partir do final de 2005, o governo iniciou um processo de pagamento antecipado da dívida externa. Os pagamentos constituíram, na verdade, em troca de dívida externa por dívida no mercado doméstico, a taxas de juros maiores. De fato, o BACEN adquiriu, por diversas vezes, dólares no mercado, injetando reais na economia. Para evitar o excesso de moeda no mercado e conter o risco de um processo inflacionário, o governo atuou no open market, comprando títulos da dívida interna, a taxas de juros mais altas e, normalmente, com prazos mais curtos.
} 
nacionais sejam observados em primeiro plano, o que parece difícil de sustentar estar sendo observado ao adotarmos uma política que privilegia os interesses dos credores estrangeiros ao priorizar a geração de superávits para o pagamento dos empréstimos externos, em detrimento dos investimentos sociais.

A Constituição Federal comanda ao Poder Público a realização de políticas públicas direcionadas à promoção do bem-estar da população. A implementação de políticas públicas pressupõe a atuação direcionada e atuante do Estado para esse fim, e não condiz com a postura de Estado mínimo preconizada pelo neoliberalismo e refletida nas medidas do Consenso de Washington.

O BACEN aponta como marco inicial do processo de "flexibilização" das normas cambiais a criação do mercado de câmbio de taxas flutuantes, em $1988^{253}$, chamado de "dólar-turismo", através da Resolução CMN n 1.552, de 22 de dezembro de 1988.

A criação desse mercado teve por objetivo possibilitar a realização de operações relacionadas a turismo, por instituições financeiras, agências de turismo e meios de turismo de hospedagem e, assim, reduzir o volume de operações realizadas no mercado paralelo, que teve amplo crescimento durante a década de 1980.

No novo mercado, a taxa de câmbio era livremente convencionada entre as partes, flutuando conforme a oferta e a procura pelas moedas estrangeiras, sem que houvesse intervenção direta do BACEN. As operações seriam sempre realizadas por instituições autorizadas pela autarquia e registradas, diariamente, no Sistema de Informações Banco Central - SISBACEN. Foram mantidos limites quantitativos para realização de operações (como, por exemplo, turismo e cartão de crédito pessoal), mas esses limites foram expandidos para atender de forma mais realista a demanda dos compradores de moeda estrangeira.

Foram previstos, ainda, mecanismos para trazer as operações realizadas no paralelo para o mercado oficial. A regulamentação permitia que moeda estrangeira adquirida no mercado paralelo pudesse ser vendida no flutuante sem que houvesse identificação do vendedor ${ }^{254}$.

${ }^{253}$ Medidas de Simplificação na Área de Câmbio, p. 5.

${ }^{254}$ O Regime Cambial Brasileiro - Evolução Recente e Perspectivas, p.11. 
Com a criação do mercado de câmbio de taxas flutuantes, passaram a coexistir dois mercados de câmbio oficiais no País. No mercado de câmbio de taxas livres ou mercado comercial, eram cursadas, principalmente, as operações de comércio exterior e operações de natureza financeira, sujeitas a registro no BACEN, tais como empréstimos externos e investimentos externos diretos.

No mercado de câmbio de taxas flutuantes eram realizadas, inicialmente, as operações de relacionadas a turismo. Posteriormente, esse mercado passou a amparar diversos outros tipos de operações não relacionados a turismo, como, por exemplo, operações de transferência de patrimônio, operações relacionadas ao investimento direto brasileiro no exterior, transferências unilaterais e pagamentos de serviços técnicos em que não havia transferência de tecnologia.

A partir da criação do mercado de câmbio de taxas flutuantes, passou a ser possível a constituição, no exterior, por pessoas físicas residentes no País, de disponibilidades no exterior, através de operações interligadas, realizadas em duas etapas.

Por um lado, o residente no País depositava recursos em conta de nãoresidente, em moeda nacional, de titularidade de instituição financeira estrangeira ${ }^{255}$, em operação denominada transferência internacional em moeda nacional. Em seguida, a instituição financeira estrangeira, através de uma operação no mercado interbancário,

255 A regulamentação aplicável previa que os depósitos nas contas de não-residentes deveriam ser classificados de acordo com os seguintes subtítulos: (i) provenientes de vendas de câmbio; (ii) de outras origens; e (iii) de instituições financeiras (Circular BACEN n 2.677, de 10 de abril de 1996). Somente poderiam ser livremente remetidos ao exterior os saldos classificados sob os subtítulos "provenientes de vendas de câmbio" ou "de instituições financeiras". Dessa forma, os recursos eventualmente depositados no País em conta de pessoa física ou jurídica não financeira não residente seriam classificados como "de outras origens" e somente poderiam ser utilizados para realização de pagamentos no País. A operação descrita, portanto, exigia que os recursos transitassem por conta de titularidade de instituição financeira estrangeira no País. As contas de não-residentes em moeda nacional, no País, são usualmente referidas como "Contas CC5", em referência à Carta-circular BACEN no 5, de 1969, que as regulamentava. O mecanismo descrito foi, muitas vezes, relacionado a operações ilícitas, especialmente à prática do crime de lavagem de dinheiro. As medidas prudenciais relacionadas às operações de câmbio ficavam comprometidas, na medida em que, para realização das remessas, realizava-se, em um primeiro momento, um depósito em conta-corrente de uma instituição financeira, e não uma efetiva operação de câmbio. Essa era apenas realizada em um segundo momento, pela própria instituição financeira, e não pelo efetivo remetente dos recursos. A fim de tentar minimizar essa situação, a regulamentação passou a prever, entre as medidas adotadas de 2005, que (i) os recursos depositados nas Contas CC-5, independentemente do subtítulo, poderiam ser livremente convertidos em moeda estrangeira (e, dessa forma, não seria necessário que os recursos transitassem por conta de titularidade de instituição financeira não-residente); e (ii) que as Contas CC-5 não poderiam ser utilizadas para realização de operação de câmbio em interesse de terceiro. Adicionalmente, há que se notar que as transferências internacionais em moeda nacional são revestidas dos mesmos critérios, disposições e exigências das operações cambiais (Regulamento do Mercado de Câmbio, Título 1, Capítulo 13, Seção 1, Itens $11,14,16$ e 17). 
enviava os recursos ao exterior e os depositava em conta corrente, no exterior, do mesmo residente no País. Podia ainda, a instituição financeira, depositar tais recursos na conta de terceiro, conforme instruído pelo remetente dos recursos.

A mesma operação, realizada ao contrário (isto é, operação no mercado interbancário, com depósito de recursos em conta de não-residente de instituição financeira estrangeira no Brasil, seguida de uma transferência internacional em moeda nacional, com transferência para a conta de um residente), proporcionava o retorno de recursos ao País.

Através das operações acima indicadas, abria-se a possibilidade de transferências financeiras do e para o exterior em casos não expressamente previstos na legislação ou na regulamentação aplicáveis. Uma empresa estrangeira, titular de investimento externo direto em empresa nacional não registrado perante o BACEN, que recebesse dividendos na empresa nacional não poderia remetê-los ao exterior pelo mercado de câmbio de taxas livres, haja vista a exigência, prevista na Lei ${ }^{\circ}$ 4.131/1962, do prévio registro do investimento para que as remessas pudessem ser feitas. Através do mecanismo acima indicado, contudo, tais recursos eram remetidos no exterior, por meio do mercado de câmbio de taxas flutuantes.

O BACEN explicou, na Cartilha, a importância das mudanças introduzidas a partir da criação do mercado de câmbio de taxas flutuantes, nos seguintes termos:

"A criação do "dólar-turismo" representou uma inovação cujas consequiências foram profundas. Com o passar do tempo, a regulamentação foi incorporando ao novo mercado novas operações que anteriormente eram cursadas no "paralelo", dada a impossibilidade de fazê-las pela regulamentação do mercado oficial (depois chamado de "comercial").

.omissis

De modo a se favorecer a repatriação de capitais no âmbito do mercado de câmbio de taxas flutuantes, a regulamentação permitiu que as instituições credenciadas pelo Banco Central comprassem e vendessem moeda estrangeira com instituições financeiras do exterior, entregando ou recebendo, em troca, moeda nacional (cruzeiros reais). De modo a operacionalizar esse mecanismo, foi necessário recorrer às determinações de um velho decreto, de $\mathrm{n}^{\circ} 42.280$, de 16.12.57, artigo 17, segundo o qual "é livre o ingresso de saída de papel-moeda nacional $e$ 
estrangeiro, bem como de ações e de quaisquer outros títulos representativos de valores". 256

Após a decisão tomada pela autoridade monetária, em janeiro de 1999, de deixar a taxa de câmbio flutuar livremente, abandonando, assim, o regime de bandas anteriormente adotado, o CMN determinou, através da Resolução $\mathrm{n}^{\circ} 2.588$, de 25 de janeiro de 1999, a unificação das posições de câmbio do mercado de câmbio de taxas flutuantes com o mercado de câmbio de taxas livres, que passou a vigorar a partir de $1^{\circ}$ de fevereiro de 1999. As peculiaridades para realização das remessas em cada um dos mercados (como as exigências de documentos e registro) foram mantidas.

Os mercados de câmbio de taxas livres e de taxas flutuantes foram unificados, por fim, no contexto de um conjunto de medidas cambiais adotadas pelo CMN para intensificar a "flexibilização" por meio da Resolução $n^{\circ} 3.265$, de 04 de março de $2005^{257}$. Hoje há apenas um mercado de câmbio oficial no País.

Entre as medidas de março de 2005, foi anunciado pelo BACEN que as pessoas físicas e as pessoas jurídicas passariam a poder "comprar e vender moeda estrangeira ou realizar transferências internacionais em reais, de qualquer natureza, sem limitação de valor, observada a legalidade da transação, tendo como base a fundamentação econômica e as responsabilidades definidas na respectiva documentação. Incluem-se nesta faculdade as compras e vendas de moeda estrangeira, por pessoas físicas ou jurídicas, residentes, domiciliadas ou com sede no País, em banco autorizado a operar no Mercado de Câmbio, para fins de constituição de disponibilidades no exterior e do seu retorno. Fica dispensada a manifestação prévia do Bacen para assunção de compromisso no exterior”.

A liberdade para realização de remessas do e para o exterior já estava prevista no Decreto-lei $\mathrm{n}^{\circ}$ 9.025/1946, mas a interpretação do BACEN era de que, até

256 O Regime Cambial Brasileiro - Evolução Recente e Perspectivas, pp. 12-13.

257 JOÃO SICSÚ menciona um temor de que a unificação dos mercados de câmbio dificultasse a re-imposição de controles sobre a quantidade movimentada de capitais. Isso porque os controles cambiais devem, de primeiro plano, separar os fluxos de moeda relativos a operações comerciais e relativos a investimentos (que anteriormente eram cursadas no mercado de câmbio de taxas livres) dos fluxos financeiros especulativos, para, em seguida, impor restrições a esses últimos. Na verdade, concordamos com o autor quando diz que a unificação dos mercados, mesmo se dificultasse a operacionalização de alguma restrição, não teria como impedi-la. Como as operações cambiais são classificadas de acordo com a sua natureza, através da identificação do código de operação que compulsoriamente é incluído no contrato de câmbio, a autoridade monetária consegue separar os tipos de fluxos e, dessa forma, impor as restrições que possam ser adequadas (Mais um passo liberalizante: comentários sobre as novas normas cambiais, pp. 4-5). 
março de 2005, as transferências ao exterior somente podiam ser cursadas se estivessem contempladas de forma específica e detalhada na por ele emitida regulamentação. Além disso, a assunção de quaisquer compromissos no exterior que pudessem resultar em solicitações de transferências de recursos para o exterior também dependia da prévia e expressa manifestação favorável do BACEN.

Na prática, como os contratos de câmbio devem ser classificados, de acordo com a natureza da operação subjacente, em um dos códigos disponibilizados pelo próprio BACEN, a manifestação específica do BACEN, de certa forma, ainda se faz necessária na ausência de um código específico para amparar a operação que se pretenda realizar.

Em março de 2005 foi revogada, ainda, a obrigatoriedade de retorno obrigatório ao País do investimento brasileiro direto no exterior, antes prevista de forma expressa na regulamentação cambial.

O processo de "flexibilização" continuou com o fim da cobertura cambial obrigatória nas operações de exportação e o registro em moeda nacional de capitais estrangeiros antes não registráveis, contemplados na Lei $\mathrm{n}^{\circ} 11.371$, de 28 de novembro de 2006, fruto da conversão da Medida Provisória n 315, de 03 de agosto de 2006, sobre os quais falaremos mais adiante.

Outra relevante alteração trazida pela Lei $\mathrm{n}^{\circ} 11.371 / 2006$ foi o fim da cobrança de multa sobre as importações brasileiras no caso de atraso no pagamento ou falha na contratação da respectiva operação de câmbio ${ }^{258}$. A multa sobre as operações de importação havia sido criada na década de 1990 para evitar movimentos especulativos envolvendo operações de importação, especialmente arbitragem entre as taxas de juros interna e externa, o que não mais se justificaria diante da possibilidade de pagamento das importações com recursos mantidos no exterior ${ }^{259}$.

Um passo seguinte no processo de diminuição dos controles foi a adoção de medidas visando facilitar o uso e a aceitação da moeda brasileira no exterior, o que incluiu

\footnotetext{
${ }^{258}$ Nos termos da Lei $\mathrm{n}^{\circ} 10.755$, de 03 de novembro de 2003, o BACEN poderia cobrar multa de até $100 \%$ do valor equivalente em reais das operações de importação naqueles casos. A Lei ${ }^{\circ}$ 11.371/2006 previu outras medidas de simplificação de menor impacto, como o fim da obrigatoriedade de celebração de contrato de câmbio nas operações de até US $\$ 3.000,00$ ou seu equivalente em outras moedas e a possibilidade de pagamento em reais nas compras de produtos em lojas francas, autorizadas a funcionar em zona primária de portos e aeroportos no País.

${ }^{259}$ Conforme explicado pelo BACEN no trabalho Medidas de Simplificação na Área de Câmbio, p. 7.
} 
a promulgação da Lei n 11.803, de 05 de novembro de 2008, fruto da conversão da Medida Provisória n 435, de 26 de junho de 2008.

Entre outras medidas, a Lei n 11.803/2008 autorizou o BACEN a manter contas de depósito em reais tituladas por bancos centrais estrangeiros e por instituições domiciliadas ou com sede no exterior que prestem serviços de compensação, liquidação e custódia no mercado internacional. Além disso, os bancos autorizados a operar no mercado de câmbio do País passaram a poder dar cumprimento a ordens de pagamento em reais recebidas do exterior, mediante a utilização de recursos em reais mantidos em contas de depósito de titularidade de instituições bancárias domiciliadas ou com sede no exterior.

De acordo com a Exposição de Motivos relativa à Medida Provisória $n$ 435/2008 (Exposição de Motivos EMI n 34-MF/BCB, de 26 de junho de 2008), essas medidas buscaram o aperfeiçoamento do arcabouço normativo aplicável às sistemáticas de pagamento e de compensação de valores envolvendo o real em transações externas, na linha do interesse do Governo brasileiro em internacionalizar a moeda nacional. A partir dessa nova legislação, residentes no exterior que precisem realizar pagamentos em reais no Brasil passaram a poder adquirir a moeda no exterior de um banco que mantenha conta em reais no Brasil e determinar a entrega da moeda nacional diretamente ao beneficiário no País.

\section{QUADRO NORMATIVO ATUAL DO CÂMBIO.}

Nas seções precedentes, procuramos trazer um histórico sobre a disciplina jurídica do câmbio no País, dando ênfase ao processo de contínua redução dos controles cambiais iniciado no final da década de 1980 e que tem sido aprofundado desde então. Nesta seção, procuraremos sistematizar o quadro normativo do câmbio no Brasil de hoje. Para melhor organização dessa análise, destacaremos algumas matérias específicas nas subseções que seguem, após serem desenvolvidas algumas considerações gerais.

De acordo com a Constituição Federal de 1988, compete à União emitir moeda; essa competência é exclusivamente exercida pelo BACEN. Compete, ainda, à União administrar as reservas cambiais do País e fiscalizar as operações de natureza 
financeira, especialmente as de crédito, câmbio e capitalização, bem como as de seguros e de previdência privada (artigo 21, incisos VII e VIII, e artigo 164).

A Carta Magna dispõe, ainda, que compete privativamente à União legislar sobre o sistema monetário, sobre a política de crédito, câmbio, seguros e transferência de valores e sobre o comércio exterior (artigo 22, incisos I, VI, VII e VIII). Por força do artigo 48, inciso XIII, da Carta Magna, cabe ao Congresso Nacional, com a sanção do Presidente da República, dispor sobre todas as matérias de competência da União, especialmente sobre matéria financeira, cambial e monetária, instituições financeiras e suas operações.

Como mencionamos ao tratar do histórico da disciplina jurídica do câmbio, a Lei $n^{\circ} 4.595 / 1964$ foi promulgada com o objetivo de propiciar maior independência para a condução da política monetária e, para tanto, criou órgãos específicos para essa matéria. $\mathrm{Na}$ ausência de promulgação de lei complementar regulamentando o Sistema Financeiro Nacional após a Constituição Federal de 1988, considera-se que a Lei $n^{\circ}$ 4.595/1964 foi recepcionada pela nova Constituição Federal como lei complementar ${ }^{260}$.

Na estrutura da Lei ${ }^{\circ} 4.595 / 1964$, o $\mathrm{CMN}^{261}$ foi criado com a finalidade de “formular a política da moeda e do crédito (...) objetivando o progresso econômico e social do País" (artigo $2^{\circ}$ ). Ou seja, o CMN é o órgão normativo da política monetária, que deve, por disposição legal expressa, ser instrumento a proporcionar o "progresso econômico e social".

Mais especificamente, a Lei ${ }^{\circ} 4.595 / 1964$ dispõe que a política do CMN objetivará, entre outros, "regular o valor externo da moeda e o equilíbrio no balanço de pagamento do País, tendo em vista a melhor utilização dos recursos em moeda estrangeira" (inciso III do artigo $3^{\circ}$ ).

\footnotetext{
${ }^{260}$ Nesse sentido, decisão do STJ no Agravo Regimental no Recurso Especial 246128/MG, (2000/00063126), $4^{\text {a }}$ Turma, r. o Ministro Sálvio de Figueiredo Teixeira, j. 29.08.2000, e decisão do STF na Medida Cautelar na Ação Direta de Inconstitucionalidade 1376 / DF, Pleno, r. o Ministro Ilmar Galvão, j. 11.12.1995. ${ }^{261} \mathrm{O}$ artigo $6^{\circ}$ da Lei ${ }^{\circ} 4.595 / 1964$ dispunha que o CMN seria integrado pelo Ministro da Fazenda (que seria seu Presidente), pelo Presidente do Banco do Brasil S.A., pelo Presidente do Banco Nacional de Desenvolvimento Econômico e Social e por sete membros nomeados pelo Presidente da República, após aprovação do Senado Federal, escolhidos entre brasileiros de ilibada reputação e notória capacidade em assuntos econômico-financeiros, com mandato de sete anos, podendo ser reconduzidos. A Lei ${ }^{\circ}$ 9.069/1995 alterou a composição do CMN, que passou a integrado apenas pelo Ministro de Estado da Fazenda (na qualidade de Presidente), pelo Ministro de Estado do Planejamento e Orçamento e pelo Presidente do Banco Central do Brasil $\left(\operatorname{artigo} 8^{\circ}\right)$.
} 
Entre as competências do CMN incluem-se, entre outros, (i) fixar as diretrizes e normas da política cambial; (ii) outorgar ao BACEN o monopólio das operações de câmbio quando ocorrer grave desequilíbrio no balanço de pagamentos ou houver sérias razões para prever a iminência de tal situação; e (iii) baixar normas que regulem as operações de câmbio, fixando limites, taxas, prazos e outras condições (incisos V, XVIII e XXXI do artigo $4^{\circ}$ da Lei $\left.n^{\circ} 4.595 / 1964\right)$. As competências devem ser exercidas segundo diretrizes estabelecidas pelo Presidente da República.

Ao BACEN compete cumprir e fazer cumprir a legislação aplicável e as regras expedidas pelo $\mathrm{CMN}$ (artigo $9^{\circ}$ ), competindo-lhe privativamente (i) emitir moeda nas condições e limites autorizados pelo CMN; (ii) efetuar o controle dos capitais estrangeiros, (iii) ser depositário das reservas oficiais de ouro e moeda estrangeira; (iv) exercer a fiscalização das instituições financeiras e aplicar as penalidades previstas; e (v) conceder autorização às instituições financeiras para realizar operações de câmbio (incisos I, VII, VIII, IX e X, “d” do artigo 10 da Lei n 4.595/1964).

Compete, ainda, ao BACEN "atuar no sentido do funcionamento regular do mercado cambial, da estabilidade relativa das taxas de câmbio e do equilíbrio no balanço de pagamentos, podendo para esse fim comprar e vender ouro e moeda estrangeira, bem como realizar operações de crédito no exterior, e separar os mercados de câmbio financeiro e comercial" (inciso III do artigo 11 da Lei ${ }^{\circ}$ 4.595/1964).

Vê-se, portanto, que na estrutura prevista na Lei $n^{\circ} 4.595 / 1964$, ainda vigente, o $\mathrm{CMN}$ é responsável pela formulação das diretrizes da política cambial, e ao BACEN compete a implementação dessa política. Esses são os principais órgãos encarregados da condução da política cambial no País.

O BACEN é compete, ainda, para apurar eventuais infrações administrativas relativas ao câmbio, bem como para aplicar penalidades caso as infrações estejam caracterizadas. Até a promulgação da Lei no 9.069/1995, os recursos contra decisões do $\mathrm{BACEN}$ por infrações às regras cambiais eram apreciados pelo $\mathrm{CMN}^{262}$. Aquela Lei transferiu para o Conselho de Recursos do Sistema Financeiro Nacional - CRSFN a competência para julgar recursos contra decisões do BACEN, relativas à aplicação de

\footnotetext{
${ }^{262}$ De acordo com o inciso XXVI do artigo $4^{\circ}$ da Lei no $4.595 / 1964$ o CMN é competente para conhecer dos recursos de decisões do BACEN.
} 
penalidades por infrações à legislação cambial, de capitais estrangeiros e de crédito rural e industrial $^{263}$ (artigo 81).

Podemos apontar, como síntese das principais características do arcabouço normativo que concerne o câmbio em vigor no Brasil, o seguinte:

(i) competência da União para legislar sobre câmbio através de ato do Congresso Nacional e com sanção do Presidente da República (artigos 22 e 48 da Constituição Federal);

(ii) competência da União para administrar as reservas cambiais e fiscalizar as operações cambiais, atribuindo-se ao CMN a competência para formulação das diretrizes da política cambial e ao BACEN para implementação dessa política (artigos 21 e 164 da Constituição Federal e Lei n 4.595/1964);

(iii) competência do BACEN para ser depositário das reservas oficiais de ouro e moeda estrangeira do País (Lei n 4.595/1964);

(iv) competência do BACEN para aplicação de penalidades no caso de infrações administrativas na área de câmbio e do CRSFN para apreciação, em segunda instância, da matéria (Lei no 9.069/1995);

(v) curso legal e curso forçado da moeda nacional (Decreto-lei $\mathrm{n}^{\circ}$ 857/1969, Lei n 10.192/2001, Código Civil);

(vi) liberdade para a realização das operações cambiais (Decreto-lei $\mathrm{n}^{\circ}$ 9.025/1946);

(vii) tratamento jurídico idêntico ao capital estrangeiro que investir no País daquele concedido ao capital nacional (Lei n ${ }^{\circ}$ 4.131/1962);

\footnotetext{
${ }^{263}$ O CRSFN foi criado pelo Decreto $\mathrm{n}^{\circ}$ 91.152, de 15 de março de 1985 , com a finalidade de julgar, em segunda e última instância, os recursos interpostos contra decisões relativas à aplicação de penalidades administrativas pelo BACEN com relação a algumas matérias antes submetidas ao CMN. A competência para julgar recursos relativos à matéria cambial foi introduzida pela Lei no 9.069/1995. O CRSFN é um órgão colegiado, composto por oito membros titulares, sendo um representante do Ministério da Fazenda, um representante do BACEN, um representante da Secretaria de Comércio Exterior, um representante da Comissão de Valores Mobiliários e quatro representantes de entidades de classe dos mercados (os representantes das seguintes entidades têm assento como membros titulares: Associação Brasileira das Companhias Abertas - ABRASCA, Associação Nacional dos Bancos de Investimento - ANBID, Federação Brasileira das Associações de Bancos - FEBRABAN e Comissão de Bolsas de Valores - CNBV).
} 
(viii) permissão para realização apenas de operações de câmbio legítimas, através de instituições autorizadas a operar no mercado de câmbio (Lei ${ }^{\circ}$ 4.182/1920, Decreto ${ }^{\circ}$ 23.258/1933 e Lei no 4.131/1962);

(ix) vedação à compensação privada de créditos e valores (Decreto-lei $\mathrm{n}^{\circ}$ 9.025/1946);

(x) registro dos capitais estrangeiros, em moeda estrangeira ou nacional, o que assegura o retorno desses capitais e dos rendimentos ou ganhos de capital a eles relativos ao exterior (Lei $\mathrm{n}^{\circ}$ 4.131/1962 e Lei $n^{\circ} 11.371 / 2006$ );

(xi) liberdade de manutenção no exterior das receitas de exportação, bem como de utilização desses recursos para pagamentos, no exterior, de obrigações do exportador (Lei n ${ }^{\circ} 11.371 / 2006$ );

(xii) ausência de obrigatoriedade de retorno ao País dos capitais brasileiros investidos no exterior, tampouco de quaisquer rendimentos auferidos no exterior;

(xiii) obrigatoriedade de declaração anual à autoridade monetária, pelos residentes no País, dos recursos e investimentos mantidos no exterior, independentemente das declarações já prestadas às autoridades fiscais (Decreto-lei nº 1.060/1969),

(xiv) realização periódica do censo de capitais estrangeiros (artigo 55 da Lei $\left.\mathrm{n}^{\circ} 4.131 / 1962\right)$;

(xv) possibilidade de, em caso de grave desequilíbrio no balanço de pagamentos ou na iminência dessa situação, o CMN poder impor restrições a importações e a remessa de rendimentos de capitais estrangeiros ao exterior, outorgando o monopólio total ou parcial das operações de câmbio ao BACEN (Lei n ${ }^{\circ} 4.595 / 1964$ e Lei $n^{\circ}$ 4.131/1962);

(xvi) repressão criminal à atribuição de falsa de identidade, à declaração de falsa informação ou sonegação de informação necessária para 
realização de operação de câmbio, bem como à realização de operação de câmbio não autorizada, inclusive para $o$ fim de promover evasão de divisas, e à manutenção de depósitos no exterior não declarados à repartição federal competente (artigos 21 e 22 da Lei $\left.n^{\circ} 7.492 / 1986\right)^{264}$.

\subsection{OPERAÇÕES DE EXPORTAÇÃO.}

O Decreto $n^{\circ}$ 23.258/1933 dispunha, no seu artigo $3^{\circ}$, serem "passiveis de penalidades as sonegações de coberturas nos valores de exportação". Impunha, assim, a obrigatoriedade de ingresso das receitas auferidas nas exportações brasileiras.

A obrigação da entrega da receita de exportação (surrender of export proceeds) é tradicionalmente uma das principais regras de controle cambial, e justifica-se pela relevância que normalmente as operações de exportação representam na obtenção de divisas pelo País. Para que um país possa garantir a disponibilidade de moeda estrangeira para fazer frente a despesas futuras, cria mecanismos para obrigar os exportadores a ingressarem com essa moeda. A obrigação de ingresso das receitas de exportação visa, ainda, garantir, que o País receba os recursos em substituição a bens que, antes de exportados, pertenciam ao seu patrimônio ${ }^{265}$.

JAYME BASTIAN PINTO explica que a forma primária de executar e controlar a entrega de receita de exportação consiste na instituição de um monopólio da compra de cambiais de exportação pelo agente de controle estatal ${ }^{266}$. Na maior parte dos países esse sistema foi substituído por outro que prevê que as instituições autorizadas podem adquirir as letras de exportação e outras receitas cambiais, mas somente podem vender a moeda estrangeira para determinados fins especificados na regulamentação (surveillance of export proceeds $)^{267}$.

\footnotetext{
${ }^{264}$ Trataremos sobre a repressão criminal a condutas relacionadas ao câmbio na Seção 12.4.4. (“Crimes cambiais"), abaixo.

265 JaYMe BAStian PINTO, Alguns Aspectos do Controle de Câmbio, p. 230.

${ }^{266}$ Esse mecanismo foi utilizado no País durante a vigência do Decreto n ${ }^{\circ} 20.451 / 1931$, quando o monopólio das operações de câmbio de exportação foi outorgado ao Banco do Brasil (Seção 10.2 - "Década de 1930").

${ }^{267}$ Ob. cit., pp. 230-231.
} 
Em virtude da obrigação de ingresso das receitas de exportação prevista no artigo $3^{\circ}$ do Decreto $n^{\circ}$ 23.258/1933, o BACEN realizava rigoroso controle dos fluxos financeiros relativos às operações de exportação, exigindo a vinculação individual dos embarques a contratos de câmbio de exportação liquidados e vice-versa.

Em 25 de abril de 1991, o então Presidente da República Fernando Collor de Mello editou um decreto sem número revogando cerca de 17.000 decretos que teriam perdido o seu objeto ou que seriam meramente autorizativos, entre eles o Decreto $\mathrm{n}^{\circ}$ 23.258/1933. Através de um novo Decreto sem número, de 14 de maio de 1998, o governo Fernando Henrique reconheceu "a nulidade do art. $4^{\circ}$ do Decreto de 25 de abril de 1991, na parte em que revogou o Decreto $\mathrm{n}^{\circ} 23.258$, de 19 de outubro de 1933". Dessa forma, a revogação do Decreto $n^{\circ}$ 23.258/1933 pelo Decreto de 25 de abril de 1991 não teria produzido efeitos e a cobertura cambial das operações de exportação teria permanecido obrigatória entre 1991 e 1998.

A explicação para se considerar nula a revogação do Decreto $\mathrm{n}^{\circ}$ 23.258/1933 pelo Decreto de 1991 foi que o Decreto de 1933 teria, em verdade, natureza de lei ordinária e somente foi editado como decreto por ser este o instrumento utilizado pelo Governo Vargas para legislar, independentemente da matéria de que se tratava. Portanto, o Decreto n ${ }^{\circ}$ 23.258/1933 apenas poderia ser alterado por uma lei ordinária, e não por um Decreto.

Essa situação gerou muitas consequiências práticas. Vários dos acusados de sonegação de cobertura cambial obrigatória nas operações de exportação questionaram a possibilidade de aplicação de penalidades pelo BACEN no período. Os principais argumentos foram: (i) o Decreto $\mathrm{n}^{\mathrm{o}} 23.258 / 1933$ tem efetivamente a natureza de decreto, pois regulamenta a Lei $\mathrm{n}^{\mathrm{o}} 4.182 / 1920$ e, portanto, poderia ter sido revogado pelo Decreto de 1991; e (ii) mesmo que se admitisse que o Decreto $\mathrm{n}^{\circ}$ 23.258/1933 tem natureza de lei ordinária e não poderia ter sido revogado pelo Decreto de 1991, não seria razoável exigir que o administrado desconsiderasse uma revogação expressa do diploma legal ${ }^{268}$.

\footnotetext{
${ }^{268}$ A fundamentação para essa alegação reside-se no erro sobre a ilicitude do fato, previsto no artigo 21 do Código Penal, nos seguintes termos: "Art. 21 - O desconhecimento da lei é inescusável. O erro sobre a ilicitude do fato, se inevitável, isenta de pena; se evitável, poderá diminuí-la de um sexto a um terço. Parágrafo único - Considera-se evitável o erro se o agente atua ou se omite sem a consciência da ilicitude do fato, quando lhe era possível, nas circunstâncias, ter ou atingir essa consciência.”
} 
O CRSFN, ao apreciar o assunto, firmou o entendimento de que o Decreto de 1991 não poderia ter revogado o Decreto no 23.258/1933 e que, portanto, a cobertura cambial obrigatória estava em vigor mesmo no período entre 1991 e 1998. Em voto vencido no julgamento do Recurso $\mathrm{n}^{\mathrm{o}} 5.730^{269}$, o Conselheiro Relator Valdecyr Maciel Gomes explica as razões políticas que levaram à decretação da nulidade do Decreto de 1991:

“(...) Em 1 de janeiro de 1995 toma posse Fernando Henrique Cardoso que, como era mesmo de se esperar, dá continuidade ao Plano Real e adota medidas complementares necessárias ao ajuste da economia. Vale insistir que, também nesta oportunidade, nada mudou em relação à questão da cobertura cambial.

Ocorre que nem tudo funcionou como planejado pelo novo governo e, passados mais 3 anos, no final de 1997, ficou claro que as mesmas medidas que permitiram o controle da inflação, acabaram por gerar recessão, inadimplência e demissões. Para agravar a situação, explode a chamada crise asiática, com severas consequiências para as reservas cambiais brasileiras, que sofreram acentuadas perdas entre abril de 1998 e outubro do mesmo ano.

omissis

Durante todo o ano de 1998, diante do risco de alastramento da crise asiática por outros países - o que efetivamente veio a ocorrer - e com a instabilidade que àquela época o período eleitoral ainda provocava no cenário econômico nacional, a preocupação com as reservas cambiais passou a ser constante e motivada (...).

omissis

De fato, as saídas líquidas de divisas cresciam em ritmo alucinante, colocando em grave risco a política cambial de bandas, posta em prática a partir de 1995. Para manter a sua política, o Banco Central vendia grandes volumes de moeda estrangeira aos agentes de mercado e o recorde de vendas de US\$ 8,7 bilhões verificado em outubro de 1997 foi largamente superado em diversos meses de 1998. (...)

Diante da clara necessidade do governo, de reverter o fluxo cambial desfavorável, a liberdade do restrito grupo de exportadores, de manter recursos no exterior, perdeu relevância. (...) O interesse público reclamava a proteção do país contra a crise que começou na Ásia e dava sinais claros de alastramento, afetando a Rússia e apontando para o Brasil.

269 Recurso no 5.730 (Processo BACEN 0301186054), r. o Conselheiro Valdecyr Maciel Gomes, j. 01.03.2007. No mesmo sentido: Recurso no 4.461 (Processo BACEN 0001045047), não consta o relator no acórdão, j. 18.08.2004, e Recurso no 5.617 (Processo BACEN 0201135079), não consta o relator no acórdão, j. 18.08.2004. 
Uma vez estabelecido o objetivo estratégico do governo, de exigir a cobertura cambial, a este competia formalizar o ato necessário a tornar o seu desejo obrigatório para a sociedade e a definir a conduta que - uma vez descumprida levaria à punição. Era o momento de publicar a norma que tornaria coercitiva a vontade estatal. Como a situação econômica do País exigia medidas ágeis, uma solução prática seria a revogação do Decreto de 1991, com a expressa repristinação do Decreto 23.258/33, que tratava inteiramente da matéria. Embora não represente a melhor técnica legislativa, o efeito repristinatório é admitido, se a intenção de revigorar a norma anteriormente revogada constar de forma expressa da Lei nova. (...) No caso, contudo, o obstáculo à revitalização do Decreto 23.258/33 era muito maior que o repúdio dos meios jurídicos ao efeito repristinatório: era inconstitucional. Isto porque, a partir da Constituição de 1988, a matéria cambial passou a ser tema cuja regulamentação tem que tramitar pelo Congresso Nacional, nos termos do artigo 48 da Carta Magna (...).

.omissis

Diante da imposição constitucional, de regulamentar a matéria cambial por meio de Lei, a repristinação do Decreto 23.258/33 não mais era possível de ser feita por decreto, posto que cambial a matéria nele tratada. A tramitação de Projeto de Lei, de iniciativa do Presidente da República, levaria tempo de que o governo aparentemente não dispunha, se considerado que "a cada dia eram bilhões de dólares que voavam do BC para o exterior" e, como disse o chefe da nação à época, "[a]ntes de qualquer coisa, em tais ocasiões é necessário agir." Mas a vontade de agir não bastava, diante das limitações enfrentadas pelo governo (...).

omissis

A opção pela Medida Provisória podia não ser viável, tampouco, em virtude da obrigatoriedade, antes da publicação da Emenda Constitucional 32, de 2001, de submissão da mesma ao Congresso Nacional, no prazo máximo de 30 dias, contados de sua publicação, nos termos do artigo 62 então vigente. Naquela época, se a Medida Provisória não fosse convertida em Lei no prazo de trinta dias, a partir de sua publicação, perderia a eficácia desde a sua edição, competindo ao Congresso Nacional a atribuição de disciplinar as relações jurídicas dela decorrentes.

Nessas circunstâncias é que surge a bem fundamentada tese de nulidade do decreto de 25 de abril de 1991, objeto do Parecer PGFN/CAF/No. 579/98, de 6 de abril de 1998, que confirma o entendimento defendido pela própria Procuradoria de que "sem sombra de dúvida o Decreto de 25 de abril de 1991 não poderia ter revogado o Decreto n. 23.258, de 19 de abril de 1933, já que este último veicula matéria 
própria de lei ordinária.” O Parecer faz uma análise crítica da situação e, após tecer comentários acerca da violação constitucional que a usurpação de funções de um poder pelo outro representa, reconhece - "numa visão pragmática e desprovida de maiores elucubrações doutrinárias" - que aos órgãos da administração não é permitido "deixar de observar" as disposições do "ato revogatório (...) editado pelo Chefe do Poder Executivo, a quem cabe a 'direção superior da administração federal' (C.F. art. 84. II)". O parecer deixa a descoberto, com esta constatação, a situação paradoxal que vivia a administração, àquela altura, obrigada que estava a dar eficácia ao ato do chefe supremo da nação, mesmo ciente da sua "flagrante inconstitucionalidade", em razão do mesmo ter - ainda nos termos do parecer "invadido, indevidamente, a esfera de competência legislativa". Isto porque a administração estava ciente de que o vício de que padecia o decreto de 25 de abril de 1991 "não autoriza[va] a conclusão de que a vigência do Dec. 23.258/33 não foi alcançada." (grifos adicionados) Em outras palavras: o Decreto 23.258/33 fora, sim, alcançado pela revogação.

$\underline{\text { Respaldado, então, na doutrina e na jurisprudência que estimulam a administração }}$ pública a anular os seus atos eivados de ilegalidade, o parecer recomenda a edição, pelo chefe do Poder Executivo, de "ato tornando nulo o Decreto de 1991, na parte que diz respeito ao Decreto 23.258/33, em virtude da sua inquestionável inconstitucionalidade." (grifamos)

Ao contrário da posição adotada pelo CRSFN, o Tribunal Regional Federal da $4^{\text {a }}$ Região já decidiu pela impossibilidade de aplicação de penalidade com base no Decreto $\mathrm{n}^{\mathrm{o}} 23.258 / 1933$ entre 1991 e $1998^{270}$.

O STJ recentemente apreciou caso em que admitiu a possibilidade de aplicação de penalidades entre 1991 e 1998, confirmando que o Decreto de 1991 não poderia ter revogado o Decreto $n^{\circ} 23.258 / 1933$, conforme entendimento prevalecente no CRSFN:

${ }^{270}$ Conforme se depreende do seguinte acórdão: "EMENTA: EMBARGOS INFRINGENTES. ILÍCITO CAMBIAL. MULTA. FUNDAMENTO LEGAL. DECRETO 23.258/33. REVOGAÇÃO. - A sanção imposta pela ocorrência do ilícito cambial caracteriza-se como multa. $\mathrm{O}$ fundamento legal, requisito formal de validade do termo de inscrição - Decreto $n^{\circ} 23.258 / 33$, foi revogado pelo Decreto de 25 de abril de 1991, o que torna nulo o processo administrativo que culminou com a aplicação da multa pecuniária. Precedentes." (grifamos) (Embargos Infringentes na Apelação Cível n ${ }^{\circ}$ 1999.71.00.006416-6, $2^{\mathrm{a}}$ Seção, Relator Edgard Antônio Lippmann Júnior, j. 09.05.2005). No mesmo sentido, as seguintes decisões daquele tribunal: Apelação Cível no 2001.71.13.003025-6, $3^{\text {a }}$ Turma, relator Luiz Carlos de Castro Lugon, j. 18.09.2007, e Apelação Cível no 1998.04.01.058009-0, $3^{\mathrm{a}}$ Turma, Relatora Marga Inge Barth Tessler, j. 05.01.2000. 
“ADMINISTRATIVO. RECURSO ESPECIAL. FINANCEIRO. OPERAÇÕES DE CRÉDITO. MULTA.

1. O Decreto n. 23.258 , de 1933, foi recepcionado pelo ordenamento jurídico posterior com o status de lei federal, por ter sido expedido com amparo no Decreto n. 19.398, de 11.11.1930, que atribuiu ao Governo Provisório da época o exercício cumulativo das funções e atribuições do Executivo e do Legislativo.

2. Instituição de multa por operações irregulares de câmbio exige lei para ter validade.

3. Impossibilidade do Decreto s/n de 25.04.1991 revogar o Decreto n. 23.258/33. Aplicação do princípio da hierarquia das leis.

4. O Decreto de 14.05 .98 reconheceu, expressamente, a nulidade do art. $4^{\circ}$ do Decreto de 25.04.91, na parte que revogou o Decreto n. 23.258, de 19.10.33.

5. Recurso especial provido."271 (grifamos)

A revogação da cobertura cambial obrigatória veio, por fim, pela Lei $n^{\circ}$ 11.371/2006 (fruto da conversão da Medida Provisória no 315/2006).

De acordo com o BACEN, a partir da criação do mercado de câmbio de taxas flutuantes (que, como visto acima, ocorreu em 1988), o exportador teria passado a conviver com uma "situação paradoxal e assimétrica". Isso porque, em virtude da cobertura cambial obrigatória, os exportadores estavam obrigados a ingressar, no País, a totalidade das suas receitas de exportação. Por outro lado, havia a possibilidade de constituição de disponibilidades no exterior sem qualquer restrição. Portanto, na prática, o exportador poderia manter os recursos no exterior, desde que trouxesse os recursos primeiramente para o País e depois os enviasse ao exterior ${ }^{272}$.

Na Exposição de Motivos da Medida Provisória nº 315/2006 (E.M.I. no 88 MF/BACEN, de 02 de agosto de 2006), o Ministro da Fazenda e o Presidente do BACEN justificam as alterações na legislação cambial "pelo interesse em adequar a legislação em vigor às características da economia contemporânea".

A Exposição de Motivos chama a atenção para o fato de que a cobertura cambial obrigatória nas operações de exportação subsistia desde 1933, independentemente

\footnotetext{
${ }^{271}$ Recurso Especial no 1009956/RS (2007/0281098-0), 1 a Turma, r. o Ministro José Delgado, j. 06.05.2008.

${ }^{272}$ Medidas de Simplificação na Área de Câmbio, p. 5.
} 
da conjuntura do mercado de câmbio existente. Reitera que, a partir da criação do mercado de câmbio de taxas flutuantes, passou a ser admitida a manutenção de disponibilidades no exterior por residentes no Brasil, o que foi aperfeiçoado com a unificação dos mercados de câmbio em 2005. A obrigatoriedade de ingresso das receitas de exportação e a faculdade de constituição de disponibilidades no exterior geravam situação de clara assimetria.

Em março de 2005, no contexto da unificação dos mercados de câmbio, o prazo para liquidação dos contratos de câmbio de exportação foi aumentado de 180 para 210 dias a partir do embarque da mercadoria ou da prestação do serviço. Essa medida permitiu a verificação de que os ingressos das operações de exportação continuaram a ocorrer dentro da normalidade, o que fez com que as autoridades acreditassem que o mercado estava preparado para uma maior abertura. O fluxo de recursos para o País teria se mantido porque a maior parte dos custos dos exportadores estaria no Brasil, o que impunha o ingresso de suas receitas. Além disso, não se pode olvidar que as elevadas taxas de juros praticadas no País tornam atraentes os investimentos no mercado doméstico.

Nesse contexto, o artigo $1^{\circ}$ da Lei $n^{\circ} 11.371 / 2006$ dispõe que "os recursos em moeda estrangeira relativos aos recebimentos de exportações brasileiras de mercadorias e de serviços para o exterior, realizadas por pessoas físicas ou jurídicas, poderão ser mantidos em instituição financeira no exterior, observados os limites fixados pelo Conselho Monetário Nacional".

Logo após a edição da Medida Provisória no 315/2006, o CMN, através da Resolução $n^{\circ} 3.389$, de 04 de agosto de 2006, determinou que 30\% das receitas de exportação poderiam ser mantidos pelo exportador no exterior. Os $70 \%$ restantes deveriam ser obrigatoriamente ingressados no País ou, ainda, ser objeto de contratos de câmbio simultâneos ${ }^{273}\left(\operatorname{artigos} 1^{\circ}\right.$ e $\left.4^{\circ}\right)$. A partir de 12 de março de 2008, o CMN, por meio da Resolução $\mathrm{n}^{\mathrm{o}} 3.548$, passou a permitir a manutenção no exterior, pelos exportadores, da totalidade das receitas de exportação. $\mathrm{O}$ artigo $1^{\text {o }}$ da Resolução $\mathrm{n}^{\circ}$ 3.389/2006 foi alterado

\footnotetext{
${ }^{273}$ A contratação de câmbios simultâneos implica a liquidação de contrato simplificado de câmbio de exportação, com liquidação simultânea de contrato simplificado de transferência financeira para constituição de disponibilidade no exterior, observando-se que "I - a compra e a venda de moeda estrangeira devem ocorrer à mesma taxa de câmbio; II - as contratações e liquidações simplificadas devem ser de mesmo valor e ocorrer na mesma data, na mesma instituição;III - o valor em reais deve transitar a crédito e a débito em conta-corrente de titularidade do exportador; IV - não haverá recepção de ordem de pagamento do exterior nem emissão de ordem de pagamento para o exterior" (artigo $4^{\circ}$ da Resolução no 3.389/2006). Em consonância com o disposto na Resolução no 3.389/2006, o BACEN, através da Circular n 3.325, de 24 de agosto de 2006, alterou o Regulamento de Câmbio para determinar que $70 \%$ das receitas de exportação deveriam ser ingressadas no País, mediante celebração e liquidação de contrato de câmbio.
} 
para dispor que "os exportadores brasileiros de mercadorias e serviços podem manter no exterior a integralidade dos recursos relativos ao recebimento de suas exportações" 274 .

O exportador pode utilizar os recursos mantidos no exterior para realização de investimentos, aplicação financeira e pagamento de obrigações próprias. É vedada a utilização dos recursos para realização de empréstimo de qualquer natureza $\left(\S 2^{\circ}\right.$ do artigo $1^{\circ}$ da Lei $\left.n^{\circ} 11.371 / 2006\right)$.

O caput do artigo $3^{\circ}$ da Lei $n^{\circ} 11.371 / 2006$ e seu parágrafo único prevêem que ao BACEN compete apenas manter registro dos contratos de câmbio relativos ao ingresso no País para recebimento de exportações de mercadorias e de serviços, e que aquela autarquia fornecerá à Receita Federal do Brasil os dados desse registro ${ }^{275}$. Esse dispositivo traz importante mudança na atuação do BACEN no que se refere às operações de exportação, ao restringir o controle, pela autarquia, ao registro dos contratos de câmbio. A Exposição de Motivos da Medida Provisória no 315/2006 diz:

“9. Outrossim, o art. $3^{\circ}$ sintetiza o que já seria apreensível do conjunto restante das normas agora alteradas ou introduzidas na legislação cambial nacional. Este dispositivo proclama, expressamente - de forma a evitar qualquer controvérsia, especialmente a partir da invocação de situações tradicionais ou interpretações a partir de outras fontes normativas - que, doravante, não mais incumbe ao Banco Central do Brasil qualquer espécie de controle de natureza cambial sobre os exportadores brasileiros relativamente aos recursos que, em decorrência desta atividade empresarial, venham a ingressar, ou não (por exemplo, na forma deste artigo, no País). Todo o controle estatal nesta matéria desloca-se para a seara tributária, ao encargo da Secretaria da Receita Federal e dentro da

\footnotetext{
${ }^{274}$ O Regulamento de Câmbio foi também alterado para refletir a mesma disposição por meio da Circular $\mathrm{n}^{\circ}$ 3.370, editada pelo BACEN em 13 de março de 2008.

${ }^{275}$ A Portaria Conjunta SRF/BCB n ${ }^{\circ} 1.064$, de 26 de outubro de 2006, dispõe, em seu artigo $1^{\circ}$, que "o Banco Central do Brasil (BCB) disponibilizará à Secretaria da Receita Federal (SRF) mecanismo eletrônico de acesso aos seguintes dados, relativos às liquidações de contratos de câmbio de exportação de mercadorias e de serviços, que serão inseridos pelas instituições integrantes do Sistema Financeiro Nacional autorizadas a operar no mercado de câmbio: I - nome empresarial e número de inscrição no Cadastro Nacional da Pessoa Jurídica (CNPJ) do vendedor da moeda estrangeira, se pessoa jurídica, ou nome e número de inscrição no Cadastro de Pessoas Físicas (CPF), se pessoa física; II - montante das liquidações, consolidado mensalmente por tipo de moeda estrangeira e por natureza da operação; III - montante do contravalor em reais das liquidações referidas no inciso II, consolidado mensalmente; e IV - nome e número do CNPJ da instituição integrante do Sistema Financeiro Nacional autorizada a operar no mercado de câmbio, compradora da moeda estrangeira." Foi instituída, pela Receita Federal, a Declaração sobre a Utilização dos Recursos em Moeda Estrangeira Decorrentes do Recebimento de Exportação - DEREX, através a Instrução Normativa n ${ }^{\circ} 726$, de 28 de fevereiro de 2007, a ser submetida anualmente pelos exportadores que mantiverem recursos no exterior.
} 
lógica própria aos procedimentos de fiscalização especialmente tributários (como resta reforçado, por exemplo, pelos arts. $8^{\circ}$ e $9^{\circ}$ da Medida Provisória). Ao Banco Central do Brasil, sem prejuízo da integral manutenção de sua competência no que diz respeito às instituições financeiras que intervenham nas operações cambiais de qualquer natureza, remanescem, somente, duas atribuições: manter registro dos contratos de câmbio de exportação e informar à Secretaria da Receita Federal, na forma que vier a ser definida em ato conjunto entre ambas as instituições, sobre os elementos contidos neste mesmo registro." (grifamos)

Verifica-se, pelo trecho acima, que a intenção dos propositores da Medida Provisória n ${ }^{\circ}$ 315/2006 foi, de fato, restringir a atuação do BACEN no controle dos fluxos de recursos das operações de exportação.

Ocorre, todavia, que o artigo $1^{\circ}$ prevê que a liberdade de manutenção dos recursos no exterior deve observar os limites fixados pelo CMN. Parece-nos que a competência do BACEN para controlar o efetivo ingresso de recursos das operações de exportação ou contratação simultânea de câmbio deve se manter durante os períodos em que os limites à manutenção de recursos no exterior sejam inferiores a 100\%, como durante a vigência da Resolução CMN n 3.389/2006. Além disso, a competência genérica do BACEN para controle dos fluxos de divisas, nos termos da Lei n ${ }^{\circ}$ 4.595/1964 mantémse inalterada.

\subsection{REGISTRO DE CAPITAIS ESTRANGEIROS.}

A Lei $\mathrm{n}^{\circ} 4.131 / 1962$, ao dispor sobre o registro dos capitais estrangeiros no BACEN, define, para esse fim, os capitais estrangeiros como sendo "os bens, máquinas e equipamentos, entrados no Brasil sem dispêndio inicial de divisas, destinados à produção de bens ou serviços, bem como os recursos financeiros ou monetários, introduzidos no país, para aplicação em atividades econômicas desde que, em ambas as hipóteses, 
pertençam a pessoas físicas ou jurídicas residentes, domiciliadas ou com sede no exterior" $\left(\operatorname{artigo} 1^{\circ}\right)^{276}$.

Os capitais estrangeiros, para que sejam considerados passíveis de registro perante o BACEN, em moeda estrangeira, com base na Lei $n^{\circ} 4.131 / 1962$, devem atender aos requisitos previstos naquela definição legal. Nos termos da Lei, a realização de remessas ao exterior relativas ao capital estrangeiro depende do seu prévio registro. Tais remessas englobam, no caso dos investimentos externos diretos, os pagamentos de dividendos, juros sobre capital próprio ou retorno do investimento no caso de sua alienação a residente no Brasil, e, no caso das operações de crédito externo, os pagamentos de principal, juros e encargos.

A ausência de registro implica a impossibilidade de remessa de recursos ao exterior relativos ao investimento. Os pagamentos podem, contudo, ser recebidos no Brasil. Portanto, o sócio residente ou domiciliado no exterior titular de investimento externo não registrado deve receber os recursos relativos ao seu investimento em moeda nacional no Brasil, da mesma forma que o credor de operação de crédito externo não registrada deve receber os respectivos pagamentos no Brasil.

No contexto da desregulamentação das normas cambiais, o BACEN tem mudado, sistematicamente, o seu entendimento sobre a caracterização do capital estrangeiro para fins de registro. Um dos requisitos previsto na Lei é a destinação dos recursos ingressados para aplicação em atividade econômica. Durante muito tempo, por exemplo, o BACEN entendeu não ser possível o registro de investimento direto em empresas brasileiras que se dedicavam a atividades imobiliárias, por entender que essas não configurariam atividades econômicas para os fins visados pela Lei. Com o passar do tempo, a autarquia mudou seu entendimento, e passou a conceder o registro em sociedades que têm por objeto o desenvolvimento de atividades imobiliárias. No que se refere aos registros de empréstimos externos, a autarquia costumava negar o registro, sob o mesmo argumento (ou seja, de que não era caso de aplicação em atividades econômicas no País), para as operações em que o devedor era pessoa natural residente no País. Esse entendimento também mudou nos últimos anos.

\footnotetext{
276 As aplicações dos investidores não residentes no mercado financeiro e de capitais domésticos estão atualmente reguladas na Resolução CMN nº 2.689, de 26 de janeiro de 2000.
} 
Atualmente, os registros dos investimentos externos diretos e das operações de crédito externo no BACEN, com base na Lei $n^{\circ}$ 4.131/1962, são realizados de forma declaratória e eletrônica, por meio de sistema disponibilizado pela autarquia. Todas as informações são inseridas no sistema eletrônico pelo próprio investidor estrangeiro e pela sociedade brasileira investida, no caso dos investimentos externos diretos, e pelo devedor, no caso das operações de crédito externo.

Na prática, o que se nota é que, em geral, a autarquia não verifica mais se os recursos estão sendo efetivamente aplicados em atividade econômica. Desde que os recursos tenham sido ingressados no País por meio da celebração de um contrato de câmbio com a finalidade de investimento externo direto ou empréstimo externo, conforme o caso, o registro é automaticamente concedido mediante a inserção no sistema eletrônico das informações pertinentes, e da declaração, por parte do representante da empresa receptora dos recursos, de que aqueles recursos estão sendo aplicados em atividade econômica, sem que seja feita uma verificação prévia, por parte do BACEN, do pleno atendimento ao comando expresso do artigo $1^{\circ}$ da Lei $\mathrm{n}^{\circ} 4.131 / 1962$.

A situação dos investimentos cujos recursos não foram ingressados no País veio a se resolver com a edição da Lei $\mathrm{n}^{\circ}$ 11.371/2006, que instituiu o registro de capital estrangeiro investido em pessoas jurídicas no País, "ainda não registrado e não sujeito a registro no Banco Central do Brasil" - os chamados "capitais contaminados". Criou-se um novo registro de capital estrangeiro, além daquele instituído pela Lei no 4.131/1962, e que teve por objetivo justamente proporcionar o registro do capital que não era passível de registro. O único requisito para a realização desse novo registro é que o investimento esteja previsto nos registros contábeis da empresa brasileira investida ou tomadora do crédito externo, de acordo com as leis aplicáveis.

Conforme explicado na Exposição de Motivos da Medida Provisória $n^{\circ}$ 315/2006 (que posteriormente foi convertida na Lei $\mathrm{n}^{\mathrm{o}} 11.371 / 2006$ ):

"11. O art. $5^{\circ}$ refere-se ao registro em moeda nacional, no Banco Central do Brasil, dos investimentos diretos, dos créditos e dos demais ativos e direitos de qualquer natureza existentes no território nacional pertencentes a pessoas físicas ou jurídicas residentes, domiciliadas ou com sede no exterior, ainda não registrados naquela Autarquia. A matéria ficou conhecida, no jargão do mercado financeiro, como "capital contaminado", estando representada por ativos de não-residentes que, em 
tese, sujeitos a registro no Banco Central do Brasil, não foram registrados por diversas razões, especialmente por não haver sido satisfeitas as disposições da Lei no 4.131, de 1962, no prazo e condições por ela estabelecidos, segundo as interpretações e critérios utilizados para admissão dos registros requeridos (...).

12. Tentativas anteriores no sentido de registrar esses capitais por norma infralegal não foram concluídas, uma vez que as formas sugeridas para sua regularização esbarraram na necessidade legal de comprovação do efetivo ingresso dos recursos no País, condicionante fundamental dos critérios definidos pelo Banco Central do Brasil para a concessão dos registros em moeda estrangeira, por força da Lei $n^{\circ}$ 4.131, de 1962. Por outro lado, mesmo a admissão, por lei posterior, do registro em moeda nacional dos recursos ingressados, como não seria possível sanar o problema com relação ao capital anteriormente ingressado, a questão deixou de ser tratada.

13. Assim sendo, tendo em vista que a medida, a par de atender demandas de investidores externos que se encontram nessa situação, contribuiria de forma efetiva para o aperfeiçoamento dos dados estatísticos relativos aos capitais estrangeiros no País, que passariam a incorporar valores pertencentes a nãoresidentes até então desconhecidos, a proposta contempla a previsão de que esses valores venham a ser registrados, em moeda nacional, obedecidos os seguintes critérios básicos:

a) os valores correspondentes constem regularmente dos registros contábeis da empresa brasileira receptora do investimento; e

b) o Banco Central do Brasil publicará dados constantes do registro.” (grifamos)

Percebe-se, pela exposição de motivos, que o objetivo da instituição do novo registro pela Lei $\mathrm{n}^{\mathrm{o}} 11.371 / 2006$ foi atender os investidores externos que se encontravam com dificuldades para retornar com o capital investido ao exterior e melhorar o controle estatístico desses investimentos. Não mais se identifica a preocupação em direcionar os investimentos externos no Brasil para atividades econômicas no País, capazes de aumentar a sua capacidade produtiva, que norteou o sistema de registro previsto na Lei $n^{\circ} 4.131 / 1962$. É importante observar que a Constituição Federal determina expressamente 
que a disciplina legal dos investimentos de capital estrangeiro deve ter como base o interesse nacional (artigo $172^{277}$ ).

Da mesma forma que os registros realizados com base na Lei ${ }^{\circ} 4.131 / 1962$, os registros feitos de acordo com a Lei $\mathrm{n}^{\circ} 11.371 / 2006$ possibilitam a realização de remessas ao exterior para retorno do capital investido e dos seus frutos. A grande diferença entre eles é que os primeiros registros (isto é, aqueles feitos sob a sistemática prevista na Lei $\mathrm{n}^{\mathrm{o}}$ 4.131/1962) são realizados na moeda estrangeira ingressada enquanto os segundos, em moeda nacional, o que pode gerar diferenças no cálculo do ganho de capital para fins de incidência do imposto de renda no momento do retorno do capital investido.

\subsection{ADIANTAMENTOS SOBRE CONTRATOS DE CÂMBIO.}

O adiantamento sobre contrato de câmbio (ACC) compreende a antecipação da totalidade ou de parte do preço em moeda nacional de moeda estrangeira comprada para entrega futura ${ }^{278}$. Celebra-se, dessa forma, um contrato de câmbio e os recursos correspondentes em moeda nacional são entregues no País ao contratante antes da entrega da moeda estrangeira respectiva ao banco correspondente no exterior.

O ACC é usualmente atrelado a uma exportação, possibilitando o recebimento, pelo exportador no País, de moeda nacional correspondente à receita de exportação, em moeda estrangeira, que ainda não lhe está disponível. Por isso, é considerado como um tipo de financiamento à exportação, mas não depende da comprovação sobre a existência da venda de bens no mercado externo que lastreará a operação de câmbio. As partes podem convencionar juros pelo período do adiantamento ${ }^{279}$.

De acordo com os dados constantes no sítio da Secretaria de Assuntos Internacionais do Ministério da Fazenda na rede mundial de computadores ${ }^{280}$, os ACC e os

\footnotetext{
277 “Art. 172. A lei disciplinará, com base no interesse nacional, os investimento de capital estrangeiro, incentivará os reinvestimentos e regulará a remessa de lucros".

${ }^{278}$ De acordo com disposto no Regulamento de Câmbio, Título 1, Capítulo 3, Seção 3, Item 1.

279 JOSÉ TADEU DE CHIARA, ob. cit., p. 159.

280 Texto intitulado Mecanismos de Financiamento Privado a Exportação.
} 
adiantamentos sobre cambiais entregues ${ }^{281}$ respondem, historicamente, por mais da metade do volume de câmbio contratado e são as modalidades mais difundidas de financiamento à exportação.

Os recursos em moeda nacional recebidos antecipadamente pelos exportadores brasileiros deveriam ser, pelo menos teoricamente, investidos na atividade exportadora. Na prática, contudo, o que se vê é que, em virtude da diferença das taxas de financiamento praticadas no mercado internacional e no mercado interno, muitas vezes os recursos recebidos no País são aplicados no mercado financeiro doméstico pelos exportadores, em vez de serem imediatamente empregados na atividade produtiva exportadora, já que assim é obtido retorno maior e mais rápido ${ }^{282}$.

Essa realidade é descrita pela Secretaria de Assuntos Internacionais do Ministério da Fazenda, no mesmo texto acima referido, conforme abaixo:

\begin{abstract}
"Importante atrativo do mecanismo é a possibilidade de o exportador realizar operações de arbitragem, captando recursos a taxas internacionais para aplicá-los à taxa doméstica mais elevada. Operações de arbitragem eram interessantes quando havia uma banda cambial, que limitava o risco de flutuação das dividas, combinada com taxas internacionais reduzidas e taxas domésticas elevadas. ${ }^{283}$ " (grifamos)
\end{abstract}

281 Os ACC e os adiantamentos sobre cambiais entregues ou sobre contratos de exportação (ACE) são operações similares. O que as diferencia é que os ACC são realizados antes dos embarques de mercadorias, enquanto que os ACE são operações pós-embarque.

${ }^{282} \mathrm{Na}$ sistemática atual, o prazo máximo entre a contratação do contrato de câmbio de exportação celebrado previamente ao embarque ou prestação do serviço e o efetivo embarque ou prestação do serviço é de 360 dias. O contrato de câmbio deve ser liquidado (o que ocorre com a entrega da moeda estrangeira no exterior ao banco brasileiro correspondente) até o último dia útil do $12^{\circ}$ mês subseqüente ao do embarque da mercadoria ou da prestação do serviço. O cancelamento ou a baixa de contrato de câmbio relativo a contrato de câmbio de exportação previamente ao embarque das mercadorias para o exterior ou da prestação dos serviços sujeita o vendedor da moeda estrangeira ao pagamento de encargo financeiro (Regulamento de Câmbio, Título 1, Capítulo 11, Seção 2, Item 1, e Título 1, Capítulo 3, Seção 7, Item 1, e artigo 12 da Lei $n^{\circ}$ 7.738, de 09 de março de 1989).

${ }^{283}$ ANDREA FERNANDES ANDREZO e IRAN SIQUEIRA LIMA explicam que o mecanismo de arbitragem envolve quatro passos: ”i) captação no mercado internacional, preferencialmente com títulos de taxas fixas; ii) compra de reais com os recursos captados no exterior [no caso das operações de ACC, os recursos já são entregues diretamente pelo banco ao exportador no País]; iii) aquisição de um título interno, com taxas préfixadas; há, ainda, a alternativa de se adquirir um título com taxas flutuantes e se travar uma taxa no mercado de DI futuro; iv) compra de dólares no mercado futuro". Os autores acrescentam que, "para evitar a possibilidade de arbitragem, o mercado futuro de câmbio deveria reproduzir a diferença entre as taxas de captação externa e de empréstimo interno, de modo que a vantagem do diferencial de juros fosse compensada pela desvalorização cambial" (Mercado Financeiro: aspectos históricos e conceituais, pp. 245-246). 
Maior vantagem social é obtida quando os recursos oriundos de operação de exportação são aplicados na atividade produtiva, com a conseqüente geração de empregos e a cadeia de reflexos positivos que o aumento de investimento acarreta para a sociedade, em vez de serem utilizados para aplicação no mercado financeiro doméstico, muitas vezes na aquisição de títulos públicos.

A política do Estado, nesse caso, tem sido a adoção de medidas de incentivo ao ACC, mas não ao direcionamento imediato dos respectivos recursos para a atividade produtiva. Cabe mencionar, ainda, mais um trecho do texto da Secretaria de Assuntos Internacionais do Ministério da Fazenda, que trata desses incentivos:

“A taxa dessas operações varia em função do risco de crédito da empresa exportadora, do valor da operação, do país de destino, das flutuações nas taxas internacionais, etc., situando-se na faixa de LIBOR $+2,5 \%$ a.a. Operações de ACC e de ACE, apesar de não contarem com nenhuma outra garantia que não o contrato de câmbio, representam crédito preferencial, com precedência sobre todos os outros créditos, inclusive tributários, nos termos do Art. 65 (sic) da Lei 4.728.

Entre os benefícios dos ACCs e ACEs, recebe especial atenção a isenção do Imposto de Renda (renúncia fiscal) que incide sobre o pagamento dos juros de operações de financiamento externo, sempre que a exportação se concretiza ("performa"); outro benefício é a não incidência de IOF, já que não se trata de operação financeira; finalmente, a norma cambial permite que não seja especificado o bem ou serviço objeto da exportação, o que confere flexibilidade ao mecanismo pela compra e venda de "performance" entre bancos e exportadores. Contudo, ACCs podem ser fechados mas não liquidados. ACCs sem lastro, isto é, sem a correspondente mercadoria no momento do embarque, são tratados como operação financeira e sujeitos ao recolhimento de IOF. No caso de o ACC ser cancelado, também caracteriza-se operação financeira, com o recolhimento de compulsório de $30 \%$ em espécie (conta reservas bancárias) sobre operações vencidas, compulsório este que não é exigível de operações correntes." (grifamos)

Apresenta-se, como uma das vantagens do ACC, o fato de que os valores correspondentes gozariam de preferência em caso de falência ou recuperação do exportador. Na verdade, o entendimento que prevaleceu nos tribunais superiores e que 
acabou por constar expressamente na Lei $\mathrm{n}^{\circ} 11.101$, de 09 de fevereiro de 2005, que regula a recuperação judicial, a extrajudicial e a falência do empresário e da sociedade empresária (Nova Lei de Falências), foi que os recursos entregues pela instituição financeira ao exportador a título de adiantamento seriam, em verdade, recursos da instituição e, portanto, deveriam ser restituídos em caso de recuperação ou falência.

A Lei $n^{\circ} 4.728$, de 14 de julho de 1965, dispõe, no seu artigo 75 e parágrafos, que o contrato de câmbio, desde que protestado por oficial competente para o protesto de títulos, constitui instrumento para se requerer ação executiva. Por esse mesmo rito, serão processadas as ações para cobrança dos ACC feitos pelas instituições financeiras aos exportadores se as importâncias correspondentes estiverem averbadas no contrato, com anuência do vendedor ${ }^{284}$.

De acordo com o $\S 3^{\circ}$ do artigo 75 acima citado, em caso de falência, o credor poderá pedir a restituição das importâncias entregues no âmbito de operações de ACC. A Súmula 307 do STJ, de 06 de dezembro de 2004, por sua vez, prevê que "a restituição de adiantamento de contrato de câmbio, na falência, deve ser atendida antes de qualquer crédito".

Nos precedentes que deram origem à Súmula $307^{285}$ e em julgamentos mais recentes, vemos que o Tribunal entendeu que os recursos em moeda nacional adiantados, em verdade, pertencem à instituição financeira que os adiantou e não àquele que os recebeu em adiantamento. Os recursos adiantados não seriam incorporados ao patrimônio daquele que tomou o adiantamento e, dessa forma, tratar-se-ia de mera restituição de recursos pertencentes a terceiros, e não de créditos, sujeitos a concurso de credores. Segue acórdão recente nesse sentido:

“COMERCIAL E PROCESSUAL CIVIL. ACÓRDÃO ESTADUAL. NULIDADE NÃO CONFIGURADA. FALÊNCIA. ADIANTAMENTO DE CONTRATO DE CÂMBIO. VALOR PERTENCENTE AO CREDOR, NÃO À MASSA.

\footnotetext{
${ }^{284}$ Nesse sentido, o Regulamento de Câmbio e Capitais Internacionais dispõe que o valor do adiantamento deve ser consignado no contrato de câmbio, mediante averbação com os seguintes dizeres: "Para os fins e efeitos do artigo 75 (e seus parágrafos) da Lei 4.728, de 14.07.1965, averba-se por conta deste contrato de câmbio o adiantamento de R\$__ (Título 1, Capítulo 3, Seção 3, Item 3).

${ }^{285}$ Entre outros, Agravo Regimental no Recurso Especial no 330.831-RS (2001/0079553-7), $3^{\text {a }}$ Turma, rel. o Ministro Carlos Alberto Menezes Direito, j. 21.05.2002; Recurso Especial no 659.201-RS (2004/0050172-1), $4^{\text {a }}$ Turma, rel. o Ministro Fernando Gonçalves, j. 05.10.2004; Recurso Especial - RS no 469.390-RS (2002/0119588-0), $4^{\mathrm{a}}$ Turma, r. o Ministro César Asfor Rocha, j. 18.09.2003; Recurso Especial - SC $\mathrm{n}^{\circ}$ 227.708-SC (1999/0075386-0), $4^{\text {a }}$ Turma, rel. o Ministro César Asfor Rocha, j: 21.03.2000.
} 


\section{IMPOSSIBILIDADE DE PRETERIÇÃO FRENTE A CRÉDITOS} TRABALHISTAS. RESTITUIÇÃO DEVIDA. SÚMULA N. 307/STJ.

I. Não padece de nulidade o acórdão estadual que enfrenta suficientemente as questões essenciais ao deslinde da controvérsia, apenas por conter conclusão desfavorável à parte.

II. Constitui entendimento pacificado na $2^{\mathrm{a}}$ Seção do Superior Tribunal de Justiça, que o adiantamento de contrato de câmbio, por representar patrimônio do credor em poder da falida e não bem da Massa, não pode ser preterido em favor de créditos trabalhistas, cabendo ser restituído ao banco titular, antes do pagamento daqueles.

III. Recurso especial conhecido em parte e provido."286 (grifamos)

A lei não prevê, como sugere o texto da Secretaria de Assuntos Internacionais do Ministério da Fazenda acima transcrito, que os créditos decorrentes de operações de ACC configuram crédito preferencial. O que, de fato, ocorre é que, sob o argumento de que os recursos objeto do ACC pertencem à instituição financeira (e não ao falido), o que seria induzido pelo fato de o $\$ 3^{\circ}$ do artigo 74 da Lei $n^{\circ} 4.728 / 1965$ falar em restituição, o STJ firmou o entendimento de que os recursos recebidos em virtude de operações de ACC não integram o patrimônio daquele que os recebeu, mas à instituição financeira que os entregou. Logo, devem ser "restituídos" à instituição que os adiantou antes de serem verificadas as regras de preferência dos créditos no concurso de credores.

Isso significa dizer que, sob a égide da Lei $\mathrm{n}^{\circ} 4.728 / 1965$, com o amparo do entendimento expresso na Súmula 307, em caso de falência do exportador, os recursos do ACC são devolvidos à instituição financeira pertinente antes mesmo dos créditos que têm preferência por força de lei, como créditos de natureza trabalhista e fiscal.

Os argumentos utilizados pelo Ministro Ruy Rosado de Aguiar, em voto divergente sobre esse assunto no julgamento do Recurso Especial n ${ }^{\circ} 316.918-\mathrm{RS}^{287}$, são dignos de nota. Diz o Ministro:

\footnotetext{
${ }^{286}$ Recurso Especial no 486.240-RS (2002/0148007-1), $4^{\text {a }}$ Turma, rel. o Ministro Aldir Passarinho Junior, j. 04.03.2008.

${ }_{287}$ Recurso Especial no 316.918-RS (2001/0041202-5), 2a Seção, rel. o Ministro Ruy Rosado de Aguiar, j. 28.11.2001.
} 
"A concessão de financiamento para exportação significa que o banco antecipa a entrega de numerário para o exportador, e essa situação não se distingue, substancialmente, do financiamento bancário comum.

O que a lei veio atribuir a esse adiantamento - porque é um adiantamento - foi a possibilidade da restituição; mas me parece ser um benefício que pode ser confrontado com outros financiamentos bancários, mas não para derrogar a preferência que a Lei de Falência dispensa aos créditos trabalhistas.

Por isso, a possibilidade da restituição não chega a alterar a classificação dos créditos da falência, a beneficiar o banco credor em detrimento dos salários. O crédito resultante do adiantamento do contrato de câmbio deve ser equiparado aos demais financiamentos bancários, que disso ele não passa, todos classificados na categoria dos quirografários.

Assegurar a restituição do financiamento bancário em prejuízo dos créditos salariais é contrariar o espírito que norteou a classificação dos créditos trabalhistas, cuja natureza alimentar não pode ser desconsiderada e merece ser mantida. A lei pode muito, inclusive denominar de restituição o que é cobrança; mas não pode dizer que o numerário objeto de um financiamento é igual à mercadoria que continua sendo de propriedade do vendedor e, por isso, restituível. A proteção ao crédito bancário certamente tem importância, mas ele não pode ser privilegiado a ponto de se socorrer da pura ficção para preterir o direito ao salário.

Além disso, deve ser ponderado o dano social decorrente da falta de pagamento de pequenas parcelas de dinheiro que atenderiam às necessidades básicas dos operários e de seus também pequenos fornecedores, com reflexos graves sobre a economia local." (grifamos)

Mais adiante, o Ministro Ruy Rosado Aguiar acrescenta o seguinte:

"Evidentemente, a antecipação do contrato de câmbio, feito em favor do exportador, é um financiamento e com ele dá-se a transferência do numerário que passou a integrar o patrimônio do falido, como em todo o mútuo. Estes recursos, entregues ao falido, são de propriedade do falido, que deles dispõe como quiser. Então, é irreconciliável o conceito de restituição com o de pagamento de financiamento, a não ser que se queira dar uma extensão para entender-se que, nesse caso, a restituição passa a ser um privilégio sobre privilégios no pagamento dos débitos do falido, com o que S. Exa., Sr. Ministro Antônio Pádua Ribeiro, não 
concorda, mas que, na verdade, é o que acontece. Isto é, trata-se de um simples crédito quirografário classificado como uma restituição e, por isso, pago antes de todos." (grifamos)

No voto vencedor naquele Recurso Especial no $n^{\circ} 16.918-R S$ (e que depois evolui para a edição da Súmula 307), o Ministro Ari Pargendler justificou seu voto ao defender que persistiam os motivos que levaram o STF a reconhecer a constitucionalidade do $\S 3^{\circ}$ do artigo 75 da Lei $n^{\circ} 4.728 / 1965$, os quais foram expostos pelo Ministro Moreira Alves no acórdão proferido pelo Plenário no Recurso Extraordinário n ${ }^{\circ} 88.827-\mathrm{RS}^{288}$, a saber:

"Ainda que se admita que os adiantamentos feitos pelas instituições financeiras aos exportadores, por conta do valor do contrato de câmbio, tenha, intrinsecamente, a natureza de mútuo, não se pode pretender que o $\$ 3^{\circ}$ do artigo 75 tenha atribuído a tais adiantamentos um privilégio que só se explicaria pelo tratamento discriminatório em função unicamente da pessoa do credor. Não é isso, com efeito, que justifica o privilégio em causa. A finalidade evidente do mencionado dispositivo legal foi a de facilitar o financiamento das exportações do País, para cuja política de desenvolvimento é indispensável o estímulo e, conseqüentemente, a ampliação da exportação de seus produtos. Inexiste, pois, tratamento discriminatório entre mutuantes, mas desigualdade resultante do fim econômico a que visa o contrato em questão, e fim econômico esse cujo interesse público justifica tratamento diverso para o meio que facilita a sua consecução." (grifamos)

A nosso ver, tem razão o Ministro Ruy Rosado Aguiar quando leciona que "a lei pode muito, inclusive denominar de restituição o que é cobrança; mas não pode dizer que o numerário objeto de um financiamento é igual à mercadoria que continua sendo de propriedade do vendedor e, por isso, restituível".

Os recursos recebidos pelo exportador na operação de ACC passam a integrar o seu patrimônio. Ao recebê-los, em moeda, o exportador investe-se em situação de liquidez e pode dispor deles ao atuar no mercado, da forma como lhe pareça conveniente, podendo, incluir, aplicá-los no mercado financeiro doméstico em vez de

\footnotetext{
${ }^{288}$ Recurso Extraordinário no 88.827 - RS, Pleno, rel. o Ministro Moreira Alves, j. 15.03.1978.
} 
utilizá-los na atividade produtiva exportadora, como sugere o texto da Secretaria de Assuntos Internacionais do Ministério da Fazenda acima citado. Há, de fato, uma relação de crédito entre a instituição financeira que adiantou os recursos ao exportador e o exportador em decorrência da operação de ACC, e não a manutenção, pelo exportador, em sua posse, de recursos da instituição.

A fundamentação oferecida, pelos tribunais superiores, desconsidera a efetiva natureza da relação entre a instituição e o exportador e, principalmente, a preferência de créditos que é determinada pelo ordenamento e que tem caráter social indiscutivelmente relevante, como créditos trabalhistas e fiscais. As decisões judiciais não enfrentam o cerne da questão, que é a análise dos efeitos práticos dessas decisões e a quem elas efetivamente beneficiam. Parece-nos que o resultado desse embate é a concessão de um privilégio ao crédito bancário, em detrimento de créditos que, por força de lei, têm privilégio. No conflito dos interesses envolvidos no embate, prevaleceu o interesse das instituições financeiras em proteger o crédito bancário.

A Nova Lei de Falências, que foi promulgada após a edição da Súmula 307, prevê, no seu artigo 86, que será restituída em dinheiro a "importância entregue ao devedor, em moeda corrente nacional, decorrente de adiantamento a contrato de câmbio para exportação, na forma do art. $75, \S \S 3^{\circ}$ e $4^{\circ}$, da Lei $n^{\circ} 4.728$, de 14 de julho de 1965 , desde que o prazo total da operação, inclusive eventuais prorrogações, não exceda o previsto nas normas específicas da autoridade competente".

A Lei cria, todavia, exceção (ainda que muito limitada) para o caso de créditos trabalhistas, ao dispor que a restituição somente será efetuada após o pagamento dos créditos trabalhistas de natureza estritamente salarial vencidos nos três meses anteriores à decretação da falência, até o limite de cinco salários-mínimos por trabalhador (artigo 86, parágrafo único, e artigo 151) ${ }^{289}$.

\footnotetext{
${ }^{289}$ Além dessa situação privilegiada na hipótese de recuperação e de falência, as operações de ACC de exportação gozam, ainda, de benefícios fiscais. Nos termos do inciso XVII do artigo $8^{\circ}$ do Decreto $n^{\circ} 6.306$, de 14 de dezembro de 2007, o IOF (Imposto sobre Operações de Crédito, Câmbio e Seguro, ou relativas a Títulos ou Valores Mobiliários) crédito é reduzido a zero nessas operações. Observe-se, contudo, que, de acordo com $\S 3^{\circ}$ do mesmo artigo, quando houver desclassificação ou descaracterização, total ou parcial, de adiantamento de contrato de câmbio, tributada à alíquota zero, o IOF será devido a partir da ocorrência do fato gerador e calculado à alíquota correspondente à operação, incidente sobre o valor desclassificado ou descaracterizado, sem prejuízo do disposto no artigo 54. Ademais, as operações de câmbio de ingresso de receitas de exportação de bens e serviços contam com o IOF câmbio reduzido a zero (inciso V do artigo 15 do mesmo Decreto).
} 


\subsection{INFRAÇÕES CAMBIAIS.}

Mencionamos, na Seção 12, acima ("Quadro normativo atual do câmbio"), que o BACEN é competente para apurar e aplicar penalidades no caso de infrações administrativas relacionadas a câmbio e que suas decisões estão sujeitas a recursos, apreciados pelo CRSFN. Pretendemos apresentar, nesse momento, as principais infrações cambiais contempladas no ordenamento jurídico vigente, inclusive aquelas que configuram crimes.

De forma geral, as infrações cambiais (tanto administrativas quanto os crimes) têm por objetivo reprimir condutas que possam criar obstáculos à boa condução da política cambial, tais como a fiscalização empreendida pelo BACEN e os controles cambiais. Pretende-se, assim, proteger as reservas de divisas do País, as quais são fundamentais para o que Estado e seus nacionais possam realizar os pagamentos que porventura tenham assumido ou venham a assumir no exterior.

12.4.1. PrÁtica DE OPERAÇÕES ILEGÍtimas DE CÂMbio. Jogo SOBRE O CÂMBIO.

A obrigatoriedade de realização das operações de câmbio através de instituições autorizadas a operar no mercado de câmbio pelo BACEN é um dos pilares do ordenamento jurídico do câmbio no Brasil. É por meio desse comando que o BACEN tem garantido seu acesso às informações sobre as operações de câmbio, bem como que garante uma análise prévia, empreendida pelas instituições autorizadas, da identidade das partes que celebram aquelas operações e da legitimidade das operações subjacentes.

Nesse contexto, a realização de operações de câmbio por meio de instituições não autorizadas configura infração de prática de operação ilegítima de câmbio, vedada pelos artigos $1^{\circ}$ e $2^{\circ}$ do Decreto $n^{\circ} 23.258 / 1933$.

A Lei $n^{\circ} 4.182 / 1920$ previu, no caput do seu artigo $5^{\circ}$, a instituição de fiscalização dos bancos com o fim de coibir o jogo sobre o câmbio, assegurando-se apenas 
as operações legítimas. $\mathrm{O} \$ 3^{\circ}$ daquele artigo autorizou o governo a expedir os regulamentos necessários para a execução daquela fiscalização. Nesse sentido, o Decreto $n^{\circ}$ 23.258/1933, no seu preâmbulo, justifica a sua edição com base na competência outorgada ao governo para a regularização das operações cambiais e repressão do jogo sobre o câmbio. É nesse contexto que o Decreto de 1933 determina quais operações de câmbio são consideradas ilegítimas, nos seguintes termos:

“Art. $1^{\circ}$ São consideradas operações de cambio ilegítimas as realizadas entre bancos, pessoas naturais ou juridicas, domiciliadas ou estabelecidas no país, com quaisquer entidades do exterior, quando tais operações não transitem pelos bancos habilitados a operar em cambio, mediante prévia autorização da fiscalização bancária a cargo do Banco do Brasil.

Art. $2^{\circ}$ São também consideradas operações de cambio ilegítimas as realizadas em moeda brasileira por entidades domiciliadas no país, por conta e ordem de entidade brasileiras ou estrangeiras domiciliadas ou residentes no exterior."

Na sua redação original, o artigo $6^{\circ}$ do Decreto $n^{\circ} 23.258 / 1933$ previa que as operações ilegítimas de câmbio seriam punidas com multas de até o dobro do valor da operação. $\mathrm{O}$ artigo 12 da Lei $\mathrm{n}^{\mathrm{0}}$ 11.371/2006 determina que as infrações ocorridas a partir de 04 de agosto de 2006 devem ser punidas com multas entre 5\% e 100\% do valor da operação.

Conforme se constata na jurisprudência do $\mathrm{CRSFN}^{290}$, o BACEN entendeu, em diversas oportunidades ${ }^{291}$, que o jogo sobre o câmbio configura infração cambial autônoma, prevista no artigo $5^{\circ}$ da Lei $n^{\circ} 4.182 / 1920$. Nos casos analisados, os acusados teriam praticado operação de arbitragem entre os mercados de câmbio de taxas livres e de taxas flutuantes, valendo-se do diferencial existente entre as taxas de câmbio nos dois segmentos do mercado. A arbitragem seria operacionalizada através de uma operação de câmbio de ingresso no mercado de câmbio de taxas livres (como, por exemplo, a título de

\footnotetext{
${ }^{290}$ As decisões do BACEN nos processos administrativos sancionadores relacionados à matéria cambial não são públicas. Nossa pesquisa relativa a esses processos limita-se aos acórdãos das decisões tomadas pelo CRSFN e que estão disponíveis na rede mundial de computadores, no sítio www.bcb.gov.br/crsfn.

${ }^{291}$ Por exemplo, Recurso $\mathrm{n}^{\circ} 4.298$ (Processo BACEN 0001024268), r. o Conselheiro Valdecyr Maciel Gomes, j. 14.12.2004, Recurso no 4.341 (Processo BACEN 0001029202), r. o Conselheiro Valdecyr Maciel Gomes, j. 23.02.2005 e Recurso no 4.339 (Processo BACEN 0001024544), r. o Conselheiro Raul Jorge de Pinho Curro, j. 20.03.2007.
} 
investimento externo direto) e, quase concomitantemente, uma operação de câmbio de saída no mercado de câmbio de taxas flutuantes (como, por exemplo, a título de constituição de disponibilidade no exterior) pelo mesmo valor ou valor semelhante. $\mathrm{O}$ BACEN entendeu muitas vezes haver indício de que as operações de câmbio eram praticadas apenas com o intuito de proporcionar ao contratante ganho correspondente à diferença das taxas de câmbio praticadas nos dois mercados, e não para proporcionar os pagamentos demandados pelos negócios ou atos subjacentes ${ }^{292}$.

O CRSFN tem sistematicamente reformado as decisões da autarquia pela prática de jogo sobre o câmbio, firmando o entendimento de que o jogo sobre o câmbio não está tipificado de forma adequada na legislação e que, portanto, não seria possível a aplicação de penalidades pelo BACEN com base nessa suposta infração.

Quanto à infração de realização de operação de câmbio ilegítima, a apreciação do BACEN e do CRSFN normalmente tem sido limitada à verificação do conteúdo probatório de cada processo. Nesse sentido, as condenações têm acontecido nos casos em que o BACEN e o CRSFN entendem que há provas suficientes no sentido de que houve ingresso de recursos no País ou saída de recursos do País sem a comprovação de que a necessária celebração dos respectivos contratos de câmbio foi realizada ${ }^{293}$.

\footnotetext{
${ }^{292}$ Em alguns casos envolvendo arbitragem entre os mercados de câmbio, o BACEN optou por pautar a acusação pela ocorrência de declaração falsa em contrato de câmbio, sob o argumento de que a natureza da operação declarada nesses casos não correspondeu à efetiva operação subjacente. Voltamos a esse assunto na Seção 12.4.3, abaixo ("Declarações falsas em contrato de câmbio. Classificação incorreta de contrato de câmbio").

293 O CRSFN apreciou diversos processos relacionados a cessões ou empréstimos de passes de atletas, nos quais clubes de futebol foram acusados de realização de operações de câmbio ilegítimas por terem recebido recursos no País sem a contratação de câmbio. O São Paulo Futebol Clube, por exemplo, foi condenado a multa de $100 \%$ sobre o valor das operações consideradas ilegítimas no Recurso $n^{\circ} 3.831$ (Processo BACEN 0001027527), r. o Conselheiro João Cox Neto, j. 19.01.2005. Também foram condenados em processos semelhantes o Club de Regatas Vasco da Gama, no Recurso n 3.232 (Processo 9700807003), relator não indicado no acórdão, j. 27.09.2001, o Goiás Esporte Clube, no Recurso n 4.383 (Processo 010109952), relator não indicado no acórdão, j. 21.01.2004, e o Grêmio Foot-ball Porto Alegrense, no Recurso $n^{\circ} 3.705$ (Processo 0001026210), relator não indicado no acórdão, j. 19.11.2003. Já a Sociedade Esportiva Palmeiras logrou êxito em demonstrar, em todas as operações questionadas pelo BACEN, ter havido o ingresso dos recursos ou o recebimento dos recursos em conta no exterior nos autos do Recurso $\mathrm{n}^{\circ} 4.114$ (Processo BACEN 0001028854), r. o Conselheiro Marcos Galileu Lorena Dutra, j. 20.09.2006. Em vários dos casos envolvendo os clubes de futebol restou caracterizada, ainda, compensação privada de créditos e valores.
} 


\subsubsection{COMPENSAÇÃO PRIVADA DE CRÉDITOS E VALORES.}

O Decreto-lei $\mathrm{n}^{\circ}$ 9.025/1946 vedou as compensações privadas de créditos e valores, usualmente referidas como compensações privadas de câmbio, nos seguintes termos:

“Art. 10. É vedada a realização de compensação privada de créditos ou valores de qualquer natureza, sujeitos os responsáveis às penalidades previstas no Decreto $n^{\circ}$ 23.258, de 19 de Janeiro de 1933."

A regulamentação do Decreto-lei n 9.025/1946, de 27 de fevereiro de 1946, previu, sobre a compensação privada de créditos e valores, o seguinte:

\section{"INSTRUÇÕES GERAIS}

1. As operações cambiais continuam privativas dos Bancos e Casas Bancárias autorizados a operar em câmbio, permanecendo vedada a realização de qualquer operação privada de crédito ou movimentação de valores de qualquer natureza, que ficam sujeitas às penalidades previstas no Decreto-lei n ${ }^{\circ} 23.258$, de 19-10-33.

. omissis

\section{CONTAS EM CRUZEIROS, DE RESIDENTES NO EXTERIOR}

1. As contas-correntes em cruzeiros, de residentes no exterior, só poderão ser mantidas em Bancos ou Casas Bancárias autorizadas a operar em câmbio, ficando a sua movimentação sob as vistas da Fiscalização Bancária, a fim de evitar as operações de compensação privada, nos têrmos do artigo $10 .^{294,}$

A legislação veda a compensação privada de créditos e valores, mas não determina os elementos caracterizadores dessa infração.

\footnotetext{
${ }^{294}$ O artigo 17 do Decreto $\mathrm{n}^{\circ} 32.285 / 1953$, ao tratar das contas em cruzeiros de residentes no exterior, dispunha que era assegurado o livre uso de fundos, títulos ou valores em moeda nacional, pertencentes a residentes no estrangeiro, "vedada, porém, a compensação privada de créditos ou valores de qualquer natureza sem a competente operação cambial". O Decreto $n^{\circ} 32.285 / 1953$ foi revogado pelo Decreto $\mathrm{n}^{\circ}$ 42.820/1957, que, ao tratar da liberdade de uso dos recursos em moeda nacional não repetiu a vedação expressa sobre a compensação privada. A repetição, contudo, não é necessária na medida em que permanece em vigor o Decreto-lei $n^{\circ} 9.025 / 1946$, que sobre ela dispõe expressamente.
} 
Em parecer aprovado pelo Ministro da Fazenda e publicado no Diário Oficial da União em 17 de março de 1982, a Procuradoria-Geral da Fazenda Nacional (PGFN) conclui pela ilegalidade das cláusulas que conferem direito de compensação (setoff) como forma de satisfação de débitos nas operações de crédito externo, por entender que, além de ser vedado expressamente pelo Decreto-lei $n^{\circ}$ 9.025/1946, o mecanismo de set-off prejudicaria o controle do BACEN sobre as operações contraídas, em descumprimento ao disposto na Lei $\mathrm{n}^{\circ} 4.131 / 1962$ e na Lei ${ }^{\circ} 4.595 / 1964$.

De acordo com a PGFN, o mecanismo de set-off previsto nos contratos de crédito externo corresponde à compensação, forma de extinção de obrigações, prevista nos artigos 1.009 e seguintes do Código Civil de 1916 e que hoje está contemplada no artigo 368 e seguintes do Código Civil de 2002. O que se busca, nas cláusulas de set-off dos contratos de crédito externo, é a possibilidade de satisfação, pelo credor, dos créditos mediante o bloqueio de eventuais depósitos do devedor no exterior.

Segundo os artigos 368 e 369 do Código Civil de 2002, a compensação exige, para sua caracterização, a existência de dívidas recíprocas (isto é, que duas pessoas sejam, ao mesmo tempo, devedora e credora uma da outra), líquidas, vencidas e de coisas fungíveis. Se considerarmos correta a premissa adotada pela PGFN, a infração de compensação privada de créditos e valores exigiria, para a sua caracterização, que os créditos em questão fossem recíprocos, líquidos, vencidos e de coisas fungíveis.

JAYME BASTIAN PINTO chamou a atenção que uma das disposições mais freqüentes na disciplina do câmbio em diversos países é a obrigatoriedade de realização das operações de câmbio por intermédio de instituições autorizadas pela autoridade monetária. As operações não realizadas através dessas instituições estariam sujeitas a penalidades. Cairiam sob essas sanções, automaticamente, as compensações privadas, as quais, nas palavras do autor, "por definição, são operações não efetuadas por intermédio de bancos". Explica o autor que "a despeito disso, a maioria das legislações vedam especificamente as compensações privadas, provavelmente mais com o intuito de elucidar as partes, muitas das quais desconhecem inteiramente os conceitos e os problemas técnicos relacionados com as operações de câmbio"295.

${ }^{295}$ Op. cit., pp. 233-237. 
O autor leciona que, tal como ocorre no nosso caso, a legislação de outros países não costuma definir o que seja a compensação privada. Para ele, "a compensação consiste em operações (pagamentos, créditos e débitos) feitos entre residentes e não residentes, os quais representam transferências, sem a interferência do banco autorizado a operar em câmbio". Acrescenta, em seguida, que a compensação só ocorre quando há efetiva transferência ou pagamento, pois somente nesses casos exige-se a interveniência de banco autorizado e só essas situações estão sujeitas ao controle cambial.

Por fim, o autor fornece alguns exemplos de operações de compensação privada, entre elas o seguinte caso: “A, residente no Brasil, é credor e devedor de B e C, ambos residentes no exterior. $\mathrm{O}$ pagamento direto de $\mathrm{B}$ a $\mathrm{C}$ extingue o débito e o crédito, sem a interferência de bancos, e sem observância da regulamentação cambial”.

Segundo os ensinamentos de JAYME BASTIAN PINTO, portanto, a compensação privada vedada no Decreto-lei $n^{\circ}$ 9.025/1946 não guarda relação com a compensação, forma de extinção de obrigações, como defendido pela PGFN. No exemplo descrito acima, inclusive, não há débitos e créditos recíprocos. Em verdade, como explica o autor, a compensação privada relaciona-se com a vedação às operações de câmbio ilegítimas, como parece deixar claro o regulamento do Decreto-lei ${ }^{\circ}$ 9.025/1946, acima transcrito, e que consistem naquelas realizadas sem a necessária participação de uma instituição autorizada pelo BACEN.

No caso objeto do parecer da PGFN, partindo-se da premissa de que a operação envolve a utilização de recursos legitimamente mantidos pelo devedor brasileiro no exterior para satisfação do débito também no exterior, parece-nos não restar configurada a compensação privada ${ }^{296}$. Isso porque o devedor brasileiro pode utilizar os recursos mantidos no exterior para pagar débitos no exterior. Esse pagamento não implica uma transferência do Brasil para o exterior; o residente não é, tampouco, obrigado a

\footnotetext{
${ }^{296}$ De acordo com o parecer da PGFN, "quando se fala em cláusula de 'set-off' para as operações externas, o que se está buscando é uma forma de garantir ao credor, na hipótese do mutuário não saldar seus compromissos, o recebimento do que lhe é devido, independentemente de qualquer autorização, mediante a realização de compensação, ou seja, através do bloqueio de eventuais depósitos do devedor no exterior". Por essa explicação, parece não ter havido efetivamente uma compensação, na forma como prevista na legislação civil brasileira, mas um pagamento, mediante transferência financeira dos recursos mantidos em depósito pelo devedor em conta corrente no exterior para o credor.
} 
ingressar os recursos no País para depois remetê-los ao exterior para realizar o pagamento. O pagamento feito no exterior não infringe qualquer regra de controle cambial no Brasil ${ }^{297}$.

Apesar de o CRSFN ter, em alguns casos, entendido restar caracterizada a infração de compensação privada de créditos e valores, os acórdãos disponíveis para consulta limitam-se, na maior parte das vezes, a indicar a condenação, sem mencionar as razões de fato e direito que a determinaram e, portanto, não auxiliam na compreensão dos elementos levados em consideração pelo BACEN e pelo CRSFN ao apreciar essa questão ${ }^{298}$.

É possível, contudo, identificar que, em algumas situações, o BACEN e o CRSFN entenderam haver caracterização da infração nos casos em que valores a receber no Brasil pela exportação de mercadorias são compensados com valores devidos em decorrência de importações. Isto é, nesses casos, seria necessária a efetiva formalização das operações cambiais. Observe-se, todavia, que os acórdãos identificados referem-se a situações ocorridas antes da entrada em vigor da Lei $\mathrm{n}^{\circ}$ 11.371/2006, ou seja, quando ainda estava em vigor a obrigatoriedade de cobertura cambial nas operações de exportação. Como as receitas de exportação podem, atualmente, ser utilizadas para pagamentos de obrigações do exportador no exterior, a interpretação do BACEN e do CRSFN pode mudar 299 .

Por fim, há que se mencionar que, pelo menos em uma oportunidade, o CRSFN confirmou entendimento do BACEN de que a interpretação do artigo 10 do Decreto-lei $\mathrm{n}^{\circ}$ 9.025/1946 deve ser restritiva, e que o cancelamento da operação que teria ocasionado a compensação (no caso, uma operação de redução de capital e o conseqüente restabelecimento do débito do investidor estrangeiro com a empresa nacional) teria o

\footnotetext{
${ }^{297}$ No registro eletrônico das operações de crédito externo perante o BACEN (Módulo Registro de Operação Financeira - ROF do Sistema de Informação Banco Central - SISBACEN), está previsto um evento de baixa do registro para os casos de pagamento no exterior sem a realização de operação de câmbio. O BACEN admite, dessa forma, que o registro da operação de crédito externo seja baixado mediante a declaração do devedor de que realizou o pagamento no exterior do crédito sem a realização de câmbio, o que demonstra o entendimento da autarquia não haver compensação privada nesses casos.

${ }^{298}$ Por exemplo, Recurso n⿳亠口冋 3.620 (Processo 0001026979), relator não indicado no acórdão, j. 27.02.2002; Recurso no 3.613 (Processo 0001026971), relator não indicado no acórdão, j. 12.12.2001.

${ }^{299}$ Por exemplo, Recurso ${ }^{\circ} 5.309$ (Processo BACEN 0301193847), relator não indicado no acórdão, j. 11.07.2004, e Recurso n 5.360 (Processo BACEN 0201122545), r. o Conselheiro Flávio Maia Fernandes dos Santos, j. 30.01.2007.
} 
condão de eliminar os efeitos que a legislação procura afastar, não sendo admitida, portanto, a aplicação de penalidades nesse caso $^{300}$.

\subsubsection{Declarações Falsas em CONTRato DE CÂMbio. ClassificaÇÃo} INCORRETA DE CONTRATO DE CÂMBIO.

A Lei $n^{\circ} 4.131 / 1962$, com alterações introduzidas pela Lei ${ }^{\circ}$ 9.069/1995, dispõe expressamente sobre as infrações cambiais de declarações falsas em contrato de câmbio e de classificação incorreta de contrato de câmbio, nos seguintes termos:

“Art. 23. As operações cambiais no mercado de taxa livre serão efetuadas através de estabelecimentos autorizados a operar em câmbio, com a intervenção de corretor oficial quando previsto em lei ou regulamento, respondendo ambos pela identidade do cliente, assim como pela correta classificação das informações por este prestadas, segundo normas fixadas pela Superintendência da Moeda e do Crédito.

omissis

§2 Constitui infração imputável ao estabelecimento bancário, ao corretor e ao cliente, punível com multa de 50 (cinqüenta) a $300 \%$ (trezentos por cento) do valor da operação para cada um dos infratores, a declaração de falsa identidade no formulário que, em número de vias e segundo o modelo determinado pelo Banco Central do Brasil, será exigido em cada operação, assinado pelo cliente e visado pelo estabelecimento bancário e pelo corretor que nela intervierem.

$\S 3^{\circ}$ Constitui infração, de responsabilidade exclusiva do cliente, punível com multa de 5 (cinco) a $100 \%$ (cem por cento) do valor da operação, a declaração de informações falsas no formulário a que se refere o $\S 2^{\circ}$.

$\S 4^{\circ}$ Constitui infração, imputável ao estabelecimento bancário e ao corretor que intervierem na operação, punível com multa equivalente de 5 (cinco) a 100\% (cem por cento) do respectivo valor, para cada um dos infratores, a classificação incorreta, dentro das Superintendência da Moeda e do Crédito, das informações prestadas pelo cliente no formulário a que se refere o $\S 2^{\circ}$ deste artigo."

\footnotetext{
${ }^{300}$ Recurso no $^{3} .970$ (Processo BACEN 0001004349), relator não indicado no acórdão, j. 26.04.2002.
} 
As infrações de falsas declarações em contrato de câmbio são divididas em duas modalidades: aquelas que se referem à declaração de falsa identidade, previstas no $\S 2^{\circ}$, e aquelas relativas às declarações de informações falsas, previstas no $\S 3^{\circ}$.

As infrações de declaração de falsa identidade são atribuíveis tanto ao cliente quanto à instituição bancária e ao corretor de câmbio que forem parte do contrato de câmbio, enquanto que as infrações de declaração de informações falsas em contrato de câmbio apenas são atribuíveis aos clientes. A instituição financeira e o corretor de câmbio são responsáveis pela verificação da identidade do cliente das operações de câmbio e, portanto, a ocorrência de declaração de falsa identidade na celebração de contrato de câmbio implica o descumprimento, por esses, dessa responsabilidade.

De fato, a Lei ${ }^{\circ}$ 9.069/1995 determinou que compete ao estabelecimento bancário a perfeita identificação do cliente ou do beneficiário nas operações de câmbio $(\text { artigo } 65)^{301}$. A Resolução $\mathrm{CMN} \mathrm{n}^{\circ} 3.568 / 2008$ reiterou o comando legal ao prever expressamente que os agentes autorizados a operar no mercado de câmbio devem observar as regras para a perfeita identificação dos seus clientes, bem como verificar as responsabilidades das partes e a legalidade das operações (artigo 18). Nas operações de câmbio de valor equivalente a até US\$3.000,00, é dispensada a apresentação da documentação referente aos negócios jurídicos subjacentes às operações de câmbio, mantendo-se a obrigação de identificação dos clientes $\left(\$ 5^{\circ}\right.$ do $\left.\operatorname{artigo} 8^{\circ}\right)$.

Os contratos de câmbio seguem padrão definido pela autoridade monetária e algumas informações são imprescindíveis, como a indicação da natureza da operação subjacente à operação de câmbio. É com base nas informações prestadas pelos clientes à instituição financeira e ao corretor de câmbio que esses inserem no contrato de câmbio o código correspondente à natureza da operação subjacente. $\mathrm{O}$ dever de classificar corretamente as operações é exclusivo da instituição financeira e do corretor de câmbio e,

\footnotetext{
${ }^{301}$ Essa obrigação não é nova. O Decreto no 42.820/1957 já prevê que as instituições autorizadas a operar no mercado de câmbio e os corretores de câmbio respondem pela identidade do cliente (artigo 12). Antes dele, o Decreto $n^{\circ} 32.285 / 1953$ contemplava dispositivo semelhante (artigo $8^{\circ}$ ). A obrigação de identificação de clientes e manutenção de cadastro atualizado também está prevista no artigo 10 da Lei $n^{\circ} 9.613$, de 03 de março de 1998, que trata do crime de lavagem de dinheiro. Nos termos dessa Lei, estão sujeitas a essa obrigação, entre outros, as pessoas jurídicas que tenham, em caráter permanente ou eventual, como atividade principal ou acessória, cumulativamente ou não a captação, intermediação e aplicação de recursos financeiros de terceiros, em moeda nacional ou estrangeira, e a compra e venda de moeda estrangeira ou ouro como ativo financeiro ou instrumento cambial (artigo $9^{\circ}$ ).
} 
portanto, uma eventual classificação incorreta é infração de responsabilidade exclusiva dessas entidades, nos termos do $\S 4^{\circ}$.

Por outro lado, os clientes são responsáveis pela veracidade das informações constantes nos contratos de câmbio e que são por eles fornecidas à instituição bancária e ao corretor de câmbio. Apenas o cliente pode ser responsabilizado pela infração de declaração de falsa informação em contrato de câmbio, conforme o $\S 3^{\circ}$, mas as instituições podem ser responsabilizadas caso falhem no dever de verificar os documentos que demonstram a legalidade das operações.

A maior parte dos casos apreciados pelo CRSFN que envolvem acusação de declaração de informações falsas em contrato de câmbio refere-se à natureza das operações subjacentes. Nesses casos, o BACEN questiona, normalmente, se a destinação dada aos recursos está de acordo com a natureza da operação declarada no contrato de câmbio através do código de classificação cambial inserido no contrato. Muitas vezes, busca-se punir tanto o cliente pela declaração falsa quanto a instituição financeira pela classificação incorreta da operação.

Foram apreciadas pelo CRSFN, no passado, diversas situações envolvendo adiantamentos para futuro aumento de capital (AFAC) por empresas brasileiras, nas quais houve o questionamento sobre declaração falsa em contrato de câmbio e classificação incorreta. Nesses casos, sócios ou futuros sócios estrangeiros de empresas brasileiras ingressavam recursos no País a título de investimento de longo prazo, no mercado de câmbio de taxas livres, antes da deliberação societária sobre o respectivo aumento de capital social. Muitas vezes, os recursos eram enviados ao exterior logo após o ingresso, pelo mercado de câmbio de taxas flutuantes. Ganhava-se com a diferença das taxas de câmbio praticadas nesses mercados.

O CRSFN firmou o entendimento de que, nos casos em que ficasse comprovada a efetiva integralização dos recursos no capital da empresa brasileira, não haveria configuração da infração, ainda que tivesse havido retorno de valores de forma simultânea ${ }^{302}$. Nesse sentido, decidiu o CRSFN no julgamento do Recurso $3896^{303}$ :

\footnotetext{
${ }^{302}$ Conforme Relatório de Atividades do Conselho de Recursos do Sistema Financeiro Nacional - CRSFN, ano-base 2003, p. 10. Se cotejarmos esse entendimento com o artigo $1^{\circ}$ da Lei $n^{\circ} 4.131 / 1962$, fica clara uma assimetria. Isso porque o referido artigo $1^{\circ}$, ao determinar o que considera "capital estrangeiro" para fins de registro, prevê que os recursos devem ser ingressados no País para aplicação em atividades econômicas. A rigor, portanto, os recursos ingressados para investimento de longo prazo que imediatamente retornassem ao
} 
"Tem-se falsa declaração em contrato de câmbio quando o agente se utiliza do instrumento de ingresso de capital estrangeiro para um fim e o destina a outro propósito com ingresso de capital estrangeiro a título de AFAC e imediata saída da mesma quantia para o exterior, obtendo ganhos financeiros com a arbitragem no mercado de câmbio e lesando as reservas cambiais nacionais. Ao tratar da mesma operação pelo lado da instituição financeira envolvida, este Conselho não vislumbrara classificação incorreta porquanto o montante de recursos financeiros internados no País, através do AFAC, fora utilizado no aumento do capital de empresa brasileira e também do setor produtivo nacional, daí a imperatividade de arquivar-se o presente processo para manter coerência nos julgamentos e, de conseguinte, segurança jurídica dos administrados." (grifamos)

O BACEN entende que resta configurada a infração de declaração falsa em contrato de câmbio, por exemplo, nos casos em que, celebrada operação de câmbio de importação, o contratante não comprova o desembaraço aduaneiro das mercadorias respectivas no prazo regulamentar. A multa aplicada nesses casos, em regra, tem sido de $50 \%$ do valor da operação. As decisões do BACEN em primeira instância nos processos administrativos sancionadores têm historicamente sido mantidas pelo CRSFN ${ }^{304}$.

\subsubsection{CRIMES CAMBIAIS.}

Além das infrações administrativas acima indicadas, que possibilitam a aplicação de penalidades pelo BACEN, o ordenamento jurídico brasileiro tipifica algumas condutas relacionadas à matéria cambial também como crime ${ }^{305}$.

exterior não se qualificaram como "capital estrangeiro" para registro com base na Lei no 4.131/1962, mas não haveria, no caso, no entender do CRSFN, declaração falsa ou classificação incorreta do contrato de câmbio. Atualmente, tais recursos estão sujeitos a registro, em moeda nacional, com base na Lei $\mathrm{n}^{\mathrm{o}}$ 11.371/2006.

${ }^{303}$ Recurso no 3.896 (Processo BACEN 9800882079), relator não indicado no acórdão, j. 30.07.2003. No mesmo sentido: Recurso $\mathrm{n}^{\mathrm{o}} 3.808$ (Processo BACEN 9800886047), relator não indicado no acórdão, j. 18.08.2003; Recurso n 3.449 (Processo BACEN 9300278123), relator não indicado no acórdão, j. 29.10..2003.

${ }^{304}$ Vê-se, por exemplo, o Recurso n ${ }^{\circ} 9.584$ (Processo BACEN 0201168848), r. o Conselheiro Darwin Corrêa, j. 27.05.2008; o Recurso n ${ }^{\circ}$ 6.248 (Processo BACEN 0201167472), r. o Conselheiro Darwin Corrêa, j. 07.04.2008.

${ }^{305}$ As instâncias administrativa e penal são consideradas independentes, não havendo, portanto, vinculação das decisões. Nesse sentido, o seguinte trecho da ementa de decisão do STJ: "É cediço que as instâncias administrativa e penal são independentes, não estando o Judiciário vinculado às decisões tomadas por órgãos da Administração Pública. Sendo assim, a decisão de órgão do Poder Executivo concluindo pela licitude da operação cambial realizada não tem o condão de retirar a justa causa da ação penal, pois durante a instrução processual podem ser colhidos e formados outros elementos de convicção" (Habeas Corpus n ${ }^{\circ}$ 26542/SP (2003/0005230-9), r. o Ministro Felix Fischer, 5 ${ }^{\mathrm{a}}$ Turma, j. 05.02.2004). 
Assim como as infrações administrativas, os crimes cambiais têm, por finalidade mediata, punir condutas que possam comprometer a boa execução da política cambial. O sujeito passivo desses crimes é sempre o Estado.

Conforme relata MANOEL PEDRo PIMENTEL, até a edição da Lei no 7.492, de 16 de junho de 1986, que define os crimes contra o Sistema Financeiro Nacional (Lei do Colarinho Branco), a única figura penal existente no ordenamento brasileiro relacionada à matéria cambial encontrava-se na Lei $\mathrm{n}^{\circ} 1.521$, de 26 de dezembro de 1951, que previa que a usura pecuniária constituía crime contra a economia popular e considerava, como usura, "cobrar ágio superior à taxa oficial de câmbio, sobre quantia permutada por moeda estrangeira" (artigo 4", “a”) $)^{306}$.

A Lei $n^{\circ} 7.492 / 1986$ prevê no artigo 21:

“Art. 21. Atribuir-se, ou atribuir a terceiro, falsa identidade, para realização de operação de câmbio:

Pena - Detenção, de 1 (um) a 4 (quatro) anos, e multa.

Parágrafo único. Incorre na mesma pena quem, para o mesmo fim, sonega informação que devia prestar ou presta informação falsa."

Esses crimes são, essencialmente, crimes de falso. O que diferencia o crime previsto no caput do crime de falsa identidade previsto no artigo 307 do Código Penal é, sobretudo, a finalidade a que se destina a falsidade. O artigo 307 do Código Penal dispõe sobre o crime de falsa identidade da seguinte forma: "Atribuir-se ou atribuir a terceiro falsa identidade para obter vantagem, em proveito próprio ou alheio, ou para causar dano a outrem". Enquanto que no crime de falsa identidade a finalidade do agente é a obtenção de vantagem, em proveito próprio ou alheio, ou para causar dano em outrem, na hipótese do caput do artigo 21 da Lei $\mathrm{n}^{\circ}$ 7.492/1986 a finalidade do agente é possibilitar a realização de uma operação de câmbio.

As condutas descritas no parágrafo único do artigo 21 possuem semelhança com o crime de falsidade ideológica previsto no artigo 299 do Código Penal, nos seguintes

${ }^{306}$ Crimes contra o sistema financeiro nacional: comentários à lei 7.492, de 16.6.86, p. 150. 
termos: "Omitir, em documento público ou particular, declaração que dele devia constar, ou nele inserir ou fazer inserir declaração falsa ou diversa da que devia ser escrita, com o fim de prejudicar direito, criar obrigação ou alterar a verdade sobre fato juridicamente relevante”. A finalidade da conduta delituosa, nesse caso, também difere daquela prevista no parágrafo único do artigo 21.

Salienta-se, ainda, a similaridade dos crimes previstos no caput e parágrafo

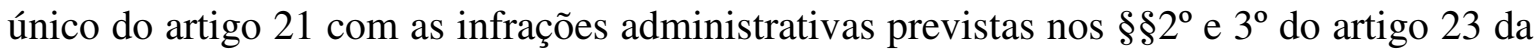
Lei $n^{\circ} 4.131 / 1965$, sobre as quais discutimos acima. De fato, as mesmas condutas poderiam ser punidas, de forma autônoma, pelo BACEN na esfera administrativa, e pelo juízo criminal competente.

Nos tipos penais previstos no artigo 21 e parágrafo único da Lei $n^{\circ}$ 7.492/1986, objetiva-se, em primeiro lugar, proteger a regularidade das operações cambiais, através do controle da veracidade das informações prestadas para a celebração do câmbio e que são necessárias ao controle realizado pela autoridade monetária. Além disso, protege-se a fé pública ${ }^{307}$.

MANOEL PEDRo Pimentel esclarece que os crimes do artigo 21 são crimes de mera conduta e, portanto, dispensam a produção de qualquer resultado material. Algumas conseqüências decorrem desse fato: sua consumação se opera com a simples atividade; são crimes instantâneos, não admitindo a tentativa ${ }^{308}$; e o concurso de pessoas somente é admitido sob a forma de participação e não de co-autoria ${ }^{309}$.

As seguintes condutas são reprimidas: (a) atribuir-se, (b) atribuir a terceiro (no caso do caput), (c) sonegar informação ou (d) prestar informação falsa (no caso do parágrafo único). As condutas referidas em (a), (b) e (d) exigem uma conduta comissiva do agente, enquanto que a conduta referida em (c) pressupõe conduta omissiva. Para a

\footnotetext{
${ }^{307}$ RODOLFO TIGRE MAIA, Dos crimes contra o sistema financeiro nacional: anotações à Lei Federal $n$. 7.492/86, pp. 129-131. Nesse sentido, de acordo com a ementa do acórdão do Recurso Especial n 800280 / RJ, o STJ decidiu que "o tipo penal previsto no art. 21, parágrafo único da Lei $\mathrm{n}^{\circ}$ 7.492/86 tem por objetivo impedir a conduta daquele que sonega informação que devia prestar ou presta informação falsa com o especial fim de realizar operação de câmbio. Tutela-se a segurança e lisura nas operações de câmbio e, em última análise o próprio mercado financeiro e a fé pública" (Recurso Especial nº 800280/RJ (2005/0175808-

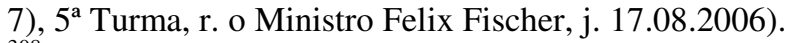

${ }^{308}$ Em sentido contrário, RODOLFO TIGRE MAIA entende que a tentativa é factível no caso do crime previsto no caput e na conduta comissiva determinada no parágrafo único ("prestar informação falsa"), nos casos em que a falsa atribuição de identidade ou a prestação da informação falsa não logram conduzir à situação de erro o destinatário da conduta (ob. cit., pp. 130-131).
}

${ }^{309}$ Ob. cit., pp. 152-154. 
caracterização dos crimes, basta a realização de uma dessas condutas e a presença de dolo especial a revelar a intenção do agente de praticar a fraude para realização de operação de câmbio. A culpa não foi considerada, pois a conduta não poderia ser realizada por imprudência, negligência ou imperícia. Não é necessária, para a caracterização do crime, que a operação de câmbio tenha se concretizado.

O artigo 22 da Lei n $^{\text {7 }}$.492/1986 prevê:

"Art. 22. Efetuar operação de câmbio não autorizada, com o fim de promover evasão de divisas do País:

Pena - Reclusão, de 2 (dois) a 6 (seis) anos, e multa.

Parágrafo único. Incorre na mesma pena quem, a qualquer título, promove, sem autorização legal, a saída de moeda ou divisa para o exterior, ou nele mantiver depósitos não declarados à repartição federal competente."

Manoel Pedro Pimentel explica que os tipos descritos no artigo 22 e no seu parágrafo caracterizam-se como normas penais em branco, pois a integração da figura delituosa se faz com "operação de câmbio não autorizada" ou "saída de moeda ou divisa para o exterior sem autorização legal". Tratam-se de elementos normativos cuja interpretação depende de outras normas ${ }^{310}$.

O crime do caput do artigo requer um elemento subjetivo especial, qual seja o dolo de promover a evasão de divisas do País. Não é admitida a forma culposa. É crime material, consumando-se no momento em que o resultado previsto é produzido, isto é, no momento em que a operação de câmbio não autorizada é efetuada ${ }^{311}$. Observe-se que a evasão de divisas é indiferente para a integração do tipo, podendo ocorrer ou não. O que

\footnotetext{
${ }^{310}$ Ob. cit., pp. 156-161. Em sentido contrário, RODOLFO TIGRE MAIA entende que o crime previsto na primeira parte do parágrafo único não é norma penal em branco. Pare esse autor, a lei tornou desde logo ilícita a saída de moeda e de divisas. As normas permissivas, se editadas, serão apenas causas de exclusão de antijuridicidade (ob. cit., pp. 136-137). Não podemos concordar com o autor. Como já visto, o ordenamento jurídico brasileiro privilegia, como um dos seus pilares, a liberdade na realização das operações cambiais. As operações não autorizadas é que devem estar expressamente previstas na legislação.

${ }^{311}$ Nesse sentido, decisões do STJ no Agravo Regimental no Recurso Especial 999575/BA (2007/02558811), $6^{a}$ Turma, r. o Ministro Hamilton Carvalhido, j. 29.04.2008, e no Conflito de Competência 90051/SP (2007/0224031-5), $3^{\text {a }}$ Seção, r. a Ministra Jane Silva (desembargadora convocada do TJ/MG), j. 24.10.2007.
} 
interessa é a intenção do agente em promovê-la. É crime comum e, portanto, pode ser praticado por qualquer agente que pratique a conduta vedada ${ }^{312}$.

Enquanto que o caput exige a intenção do agente de promover a evasão de divisas para a caracterização do crime, a primeira parte do parágrafo único não requer qualquer elemento subjetivo especial, bastando, para a configuração do crime, que haja a saída de moeda ou divisa para o exterior sem autorização legal. Como bem observa MANOel Pedro Pimentel, a primeira parte do parágrafo único acaba por tornar desnecessário o caput do artigo ${ }^{313}$.

Se, por um lado, a exigência do elemento subjetivo especial do caput restringe o campo de repressão penal, pois se a intenção do agente for outra que a de promover a evasão de divisas, não haverá caracterização do crime, o parágrafo único, por outro, alarga bastante a rede de repressão para abarcar qualquer hipótese de saída não autorizada de moeda ou divisas, independentemente da intenção do agente.

Há que se observar, ainda, que diferentemente do que ocorre no caput, a primeira parte do parágrafo único exige a efetiva saída de divisa ou moeda para o exterior, ao estabelecer que incorre na mesma pena quem promove a saída de divisa ou moeda sem autorização legal. Em ambos os casos, é admitida a tentativa, pois podem ser caracterizados atos de início de execução e resultados correspondentes. É possível, também, o concurso de pessoas, podendo haver co-autoria e participação.

Os tipos do parágrafo único são dolosos. A forma culposa não é admitida, haja vista a ausência de previsão legal nesse sentido.

A conduta "manter", prevista no parágrafo único, indica um crime de mera conduta, de caráter permanente, que tem como requisito a habitualidade. $\mathrm{O}$ crime está consumado enquanto forem mantidos os depósitos não declarados. Não é admitida, portanto, a tentativa e, no que se refere ao concurso de pessoas, apenas a participação é possível.

\footnotetext{
${ }^{312}$ De acordo com a decisão do STJ no Recurso Ordinário em Habeas Corpus no 9281 / PR (1999/01042798), $5^{\text {a }}$ turma, r. o Ministro Gilson Dipp, j. 13.09.2000. Decidiu-se, ainda, nesse caso que "a evasão não pressupõe, necessariamente, a saída física do numerário, consistindo, de fato, no prejuízo às reservas cambiais brasileiras, independentemente de estar entrando ou saindo o dinheiro do País."

${ }^{313} \mathrm{O}$ autor explica que o Projeto originário da Câmara dos Deputados somente sugeriu o disposto no caput. A emenda no Senado incluiu o parágrafo único para alcançar as hipóteses não contidas no caput (isto é, os casos em que não havia a intenção de promover a evasão de divisas do País), mas acabou por tornar o caput desnecessário (ob. cit., p. 158).
} 
A segunda conduta descrita no parágrafo único (manter, no exterior, depósitos não declarados à repartição federal competente) indica uma clara preocupação de proteção à ordem tributária, sem prejuízo da proteção ao controle cambial realizado pelo BACEN. De fato, o residente no País que mantém depósitos no exterior tem a obrigação de declarar esses depósitos a duas "repartições federais", de forma independente: à Receita Federal do Brasil e ao BACEN.

Por fim, observe-se que os crimes previstos nos artigos 21 e 22 da Lei $n^{o}$ 7.492/1986 são crimes antecedentes dos crimes de "lavagem" ou ocultação de bens, direitos e valores, conforme o disposto na Lei ${ }^{\circ}$ 9.613, de 03 de março de $1998^{314}$.

314 Dispõe o artigo $1^{\text {o }}$ da referida Lei: “Art. $1^{\circ}$. Ocultar ou dissimular a natureza, origem, localização, disposição, movimentação ou propriedade de bens, direitos ou valores provenientes, direta ou indiretamente, de crime: (...) VI - contra o sistema financeiro nacional; (...) Pena: reclusão de três a dez anos e multa." Nesse sentido, decisão do STJ no Recurso Especial 886068/RS (2006/0192871-5), 5 a Turma, r. o Ministro Felix Fischer, j. 10.05.2007. 


\section{CONCLUSÕES}

1. Nas sociedades capitalistas, a moeda é medida da riqueza e denominador comum sobre o qual gira toda a vida econômica. Tem papel primordial na reprodução do regime ao permitir a divisão do trabalho e a circulação de riquezas.

2. Os efeitos das relações intermediadas por moeda extrapolam a relação bilateral entre as partes de um negócio jurídico e espalham-se por toda a sociedade, já que o recebimento de moeda induz o seu titular a celebrar uma nova relação de troca, também instrumentada por moeda, para satisfazer suas necessidades.

3. As funções típicas da moeda - instrumento de troca, meio de pagamento, reserva de valor e padrão de valor - apenas são garantidas dentro da ordem jurídica sob a qual é emitida. Fora dela, a moeda torna-se bem de caráter especial, que, em razão das restrições impostas pelo curso legal, deve ser convertida em moeda nacional, através da celebração de contrato de câmbio, para investir seu titular na situação de liquidez.

4. A taxa de câmbio expressa a relação de troca entre a moeda nacional e a moeda estrangeira e está sujeita à influência de diversos fatores que extrapolam a simples comparação dos seus poderes de compra nos países emissores, tais como a relação internacional de troca e outros atos de política econômica dos Estados pertinentes.

5. No exercício da política cambial, o Estado age de forma a preservar a estabilidade da moeda nacional e garantir o seu poder de compra, bem como a existência de divisas necessárias para o pagamento das obrigações externas assumidas pelo Estado e por seus nacionais.

6. O nível da intervenção do Estado no exercício da política cambial é ditado pelo regime de câmbio adotado. A forma de atuação se dá pela imposição de controles cambiais ou pela intervenção da autoridade monetária diretamente no mercado. No Brasil, o CMN tem competência para disciplinar a política cambial e o BACEN para implementá-la. 
7. Ao exercer a política cambial, o Estado, deve, como em todos os seus atos, observar as normas constitucionais, em especial seus fundamentos e princípios. Além disso, a política cambial deve condizer e buscar instrumentar os objetivos fixados no ordenamento jurídico e cuja concretização é a finalidade das políticas públicas.

8. As políticas públicas são programas de ação governamental destinados à implementação dos objetivos eleitos pela sociedade como prioritários e que têm por finalidade última a promoção do maior bem-estar social. Esses objetivos podem ser sintetizados pelo desenvolvimento nacional, em razão das amplas mudanças estruturais que ele implica. As políticas públicas necessitam, para sua realização, de planejamento direcionado para esse fim.

9. As principais diretrizes do ordenamento jurídico do câmbio no Brasil podem ser assim sumarizadas:

(i) competência da União para (a) legislar sobre câmbio através de ato do Congresso Nacional e com sanção do Presidente da República, e para (b) administrar as reservas cambiais e fiscalizar as operações cambiais, atribuindo-se ao CMN a competência para formulação das diretrizes da política cambial e ao BACEN para sua implementação;

(ii) competência do BACEN para ser depositário das reservas oficiais de ouro e moeda estrangeira no País;

(iii) competência do BACEN para aplicação de penalidades no caso de infrações administrativas na área de câmbio e do CRSFN para apreciação, em segunda instância, da matéria;

(iv) curso legal e curso forçado da moeda nacional;

(v) liberdade para a realização das operações cambiais;

(vi) tratamento jurídico idêntico ao capital estrangeiro que investir no País daquele concedido ao capital nacional; 
(vii) vedação às operações de câmbio legítimas e à compensação privada de créditos e valores, bem como às declarações falsas em contrato de câmbio e à classificação incorreta dos contratos de câmbio;

(viii) registro dos capitais estrangeiros, que assegura o retorno desses capitais e dos seus frutos ao exterior;

(ix) liberdade de manutenção no exterior das receitas de exportação, bem como de utilização desses recursos para pagamentos de obrigações do exportador no exterior;

(x) ausência de obrigatoriedade de retorno ao País dos capitais brasileiros investidos no exterior e de seus rendimentos;

(xi) obrigatoriedade de declaração anual à autoridade monetária, pelos residentes no País, dos recursos e investimentos mantidos no exterior, e realização periódica do censo de capitais estrangeiros;

(xii) possibilidade de, em caso de grave desequilíbrio no balanço de pagamentos ou na iminência dessa situação, o CMN impor restrições a importações e a remessa de rendimentos de capitais estrangeiros ao exterior, outorgando o monopólio total ou parcial das operações de câmbio ao BACEN;

(xiii) repressão criminal à atribuição de falsa de identidade, à declaração de falsa informação ou sonegação de informação necessária para realização de operação de câmbio, bem como à realização de operação de câmbio não autorizada, inclusive para o fim de promover evasão de divisas, e à manutenção de depósitos no exterior não declarados à repartição federal competente.

10. A partir do final da década de 1980, em consonância com a ideologia neoliberal consagrada no Consenso de Washington, teve início um processo de desregulamentação cambial, que tem promovido a progressiva diminuição dos controles cambiais. Muitas das mudanças se deram por alterações nos regulamentos editados pelo CMN e pelo BACEN no exercício da capacidade normativa de conjuntura e pela mudança de interpretação dos textos normativos pela autoridade monetária. Algumas importantes 
mudanças realizadas no contexto do afrouxamento dos controles cambiais foram o fim da obrigatoriedade de cobertura cambial obrigatória nas operações de exportação e a instituição do registro em moeda nacional dos capitais estrangeiros que não qualificam para registro nos termos da Lei $\mathrm{n}^{\circ} 4.131 / 1962$.

11. A Constituição Federal, ao prever as finalidades a serem perseguidas pelo Estado, não admite a sua omissão como política institucionalizada. Ao contrário, determina a direção da sua atuação no sentido de cumprir os objetivos de bem-estar geral nela previstos. A decisão do Estado de se omitir, em determinada circunstância, deve ser devidamente justificada como condizente com a ordem jurídica vigente. 


\section{BIBLIOGRAFIA}

\section{a) Obras consultadas}

ALVES, Alaôr Caffé Alves. Estado e Ideologia. Aparência e Realidade. São Paulo: Editora Brasiliense, 1987.

ANDREZO, Andrea Fernandes e LIMA, Iran Siqueira. Mercado Financeiro: aspectos históricos e conceituais. São Paulo: Pioneira Thomson Learning, 2001.

ARIDA, Pérsio. Aspectos Macroeconômicos da Conversibilidade: uma discussão do caso brasileiro. Texto disponível em www.iepecdg.com. Acessado em 28 de julho de 2008.

ASCARELLI, Tullio. Obbligazioni Pecuniarie. Bologna: Nicola Zanichelli Editore, 1959.

BALEEIRO, Aliomar. Uma Introdução à Ciência das Finanças, $15^{\mathrm{a}}$ edição, Rio de Janeiro: Editora Forense, 2001.

BARROSO, Luís Roberto. A Ordem Econômica Constitucional e os Limites à Atuação Estatal no Controle de Preços, in Revista Diálogo Jurídico, Salvador, CAJ - Centro de Atualização Jurídica, $\mathrm{n}^{\circ}$ 14, junho/agosto, 2002. Disponível na Internet: http://www.direitopublico.com.br. Acessado em 20 de agosto de 2008.

BELLUZZO, Luiz Gonzaga de Mello, ALMEIDA, Júlio Gomes de. Depois da Queda: a economia brasileira da crise da dívida aos impasses do Real, Rio de Janeiro: Civilização Brasileira, 2002.

BERCOVICI, Gilberto. A Constituição Dirigente e a Crise da Teoria da Constituição, in Teoria da Constituição: estudos sobre o lugar da política no Direito Constitucional, Rio de Janeiro: Editora Lumen Júris, 2003, pp. 75- 150. 
Constituição Econômica e Desenvolvimento. Uma leitura a partir da Constituição de 1988, São Paulo: Malheiros Editores, 2005.

Planejamento e políticas públicas: por uma nova compreensão do papel do Estado, in Políticas Públicas: Reflexões sobre o Conceito Jurídico, organização BUCCI, Maria Paula Dallari. São Paulo: Saraiva, 2006, pp. 143-161.

BOBBIO, Norberto. Teoria Geral da Política: a filosofia política e as lições dos clássicos, organizado por Michelangelo Bovero, Rio de Janeiro: Elsevier, 2000, 16ª reimpressão.

BRESSER-PEREIRA, Luiz Carlos. Desenvolvimento e Crise no Brasil. História, Economia e Política de Getúlio Vargas a Lula, 5 a edição atualizada, São Paulo: Ed. 34, 2003.

- O Sistema Econômico Brasileiro, publicado em Conjuntura Econômica, 59 (4), abril 2005: 16-17. Disponível em www.bresserpereira.org.br/Works/SmallPapers/5.SistemasEconomicoBrasileiro-

ConjEc.p.pdf. Acessado em 19 de agosto de 2008.

- Tendência à Sobreapreciação da Taxa de Câmbio e

Desenvolvimento Sustentado no Brasil. Trabalho apresentado ao painel Empresa Nacional e Estratégia de Desenvolvimento do $5^{\circ}$ Fórum de Economia da Fundação Getúlio Vargas, São Paulo, EESP, 16 de setembro de 2008.

BUCCI, Maria Paula Dallari. As Políticas Públicas e o Direito Administrativo, in Revista Trimestral de Direito Público, volume 13, ano 1996, pp. 134-143.

Direito Administrativo e Políticas Públicas. São Paulo: Saraiva, 2006. O Conceito de Política Pública em Direito, in Políticas Públicas: Reflexões sobre o Conceito Jurídico, organização BUCCI, Maria Paula Dallari. São Paulo: Saraiva, 2006, pp. 1-49. 
CANOTILHO, José Joaquim Gomes. Direito Constitucional e Teoria da Constituição, $7^{\mathrm{a} e d i c ̧ a ̃ o, ~ C o i m b r a: ~ E d i c ̧ o ̃ e s ~ A l m e d i n a, ~} 2003$.

CLARK, Giovani. Política Econômica e Estado, in Revista de Direito Mercantil, Industrial, Econômico e Financeiro, volume 141, ano XVL, janeiro-março/2006, pp. 41-48.

COMPARATO, Fábio Konder. O Indispensável Direito Econômico, in Revista dos Tribunais, volume 353, 1968, pp. 14-26.

. Contrato de Câmbio, in Revista dos Tribunais, volume 575, 1983,

pp. 54-62.

Ordem Econômica na Constituição de 1988, in Revista de Direito Público, nº 93, janeiro-março de 1990, ano 23, pp. 263-276.

A Organização Constitucional da Função Planejadora, in Desenvolvimento Econômico e Intervenção do Estado na Ordem Constitucional: estudos jurídicos em homenagem ao Professor Washington Peluso Albino de Souza, Porto Alegre: Sergio Antonio Fabris Editor, 1995, pp. 77-93.

Ensaio sobre o Juízo de Constitucionalidade de Políticas Públicas, in Interesse Público nº 16-2002, pp. 49-63.

CORTEZ, Tiago Machado. Moeda, Estado e Direito: o Papel do Estado na Ordem Monetária e seu Controle. Tese de Doutoramento apresentada na Faculdade de Direito da Universidade de São Paulo - USP, São Paulo, 2004.

DE CHIARA, José Tadeu. Moeda e Ordem Jurídica. Tese de doutoramento defendida em 1986 na Faculdade de Direito da Universidade de São Paulo.

DERANI, Cristiane. Política pública e a norma política, in Políticas Públicas: Reflexões sobre o Conceito Jurídico, organização BUCCI, Maria Paula Dallari. São Paulo: Saraiva, 2006, pp. 131-142. 
DWORKIN, Ronald. Taking Rights Seriously. Cambridge, Massachusetts: Harvard University Press, 1977.

FABRI, Andréa Queiroz. Política Econômica e Desenvolvimento, in Revista de Direito Público da Economia - RDPE, Belo Horizonte, ano 4, n. 16, pp. 9-26, out./dez. 2006.

FAGUNDES, Miguel Seabra. O controle dos atos administrativos pelo Poder Judiciário, $6^{a}$ edição rev. e atualizada, São Paulo: Saraiva, 1984.

FERREIRA FILHO, Manoel Gonçalves. Direito Constitucional Econômico. São Paulo: Saraiva, 1990.

Curso de Direito Constitucional, $34^{\mathrm{a}}$ edição revisada e atualizada, São Paulo: Saraiva, 2008.

FRANCO, Gustavo H. B. O Plano Real e Outros Ensaios. Rio de Janeiro: Francisco Alves, 1995.

Crônicas da convergência: ensaios sobre temas já não tão polêmicos. Rio de Janeiro: Topbooks, 2006.

Um Longa Adolescência: Fases da história monetária brasileira.

Disponível em www.econ.puc-rio.br/gfranco/uma\%20longa\%20adolesc\%EAncia.pdf. Acessado em 28 de julho de 2008.

FURTADO, Celso. Formação econômica do Brasil, 18ªedição, São Paulo: Nacional, 1982.

GALA, Paulo Sérgio de Oliveira Simões. Política Cambial e Macroeconomia do Desenvolvimento. Tese de Doutoramento defendida em 2006 na Escola de Administração de Empresas de São Paulo.

GARCIA, Márcio G. P. e URBAN, Fabio. O Mercado Interbancário de Câmbio no Brasil, 25 de março de 2004. Texto disponível em http://www.econ.pucrio.br/Mgarcia/Papers/Garcia\&Urban040325.PDF. Acessado em 11 de janeiro de 2009. 
GRAU, Eros Roberto. A Ordem Econômica na Constituição de 1988 (interpretação e crítica), 10a edição, São Paulo: Malheiros Editores, 2005.

Ensaio e Discurso sobre a Interpretação/Aplicação do Direito, $3^{\mathrm{a}}$ edição, São Paulo: Malheiros Editores, 2005.

O Direito Posto e o Direito Pressuposto, $6^{\mathrm{a}}$ edição, São Paulo:

Malheiros Editores, 2005.

GREMAUD, Amaury Patrick; VASCONCELlOS, Marco Antonio Sandoval de, TONETO JÚNIOR, Rudinei. Economia Brasileira Contemporânea, $6^{\mathrm{a}}$ edição, São Paulo: Atlas, 2005.

GUDIN, Eugênio. Princípios de Economia Monetária, $1^{\circ}$ volume, $4^{\mathrm{a}}$ edição, Rio de Janeiro: Agir Editora, 1960.

HABERMAS, Juergen. A Crise de Legitimação no Capitalismo Tardio, $2^{\mathrm{a}}$ edição, Rio de Janeiro: Edições Tempo Brasileiro, 2002.

HUBERMAN, Leo. História da Riqueza do Homem, $21^{\text {a }}$ edição, São Paulo: Editora LTC, 1987.

KRUGMAN, Paul R. e OBSTFELD, Maurice. Economia Internacional: teoria e política, $6^{\text {a }}$ edição, São Paulo: Pearson Addison Wesley, 2005.

LANZANA, Antonio Evaristo Teixeira. Economia Brasileira: fundamentos e atualidades, $2^{a}$ edição, São Paulo: Atlas, 2002.

LAUBADÈRE, André de. Direito Público Económico. Coimbra: Livraria Almedina, 1985.

LEÃES, Luiz Gastão Paes de Barros. Controle Cambial e Fluxo Internacional da Moeda Nacional, em Revista de Direito Mercantil, Industrial, Econômico e Financeiro, ano XXX, $\mathrm{n}^{\circ} 83$, julho-setembro de 1991, pp. 11-17. 
MAIA, Rodolfo Tigre. Dos Crimes contra o Sistema Financeiro Nacional: anotações à Lei Federal n. 7.492/86, São Paulo: Malheiros Editores, 1996.

MANKIW, N. Gregory. Introdução à Economia, tradução da $3{ }^{\text {a }}$ edição norte-americana, São Paulo: Cengage Learning, 2008.

MARINHO, Josaphat. A Ordem Econômica nas Constituições Brasileiras, Revista de Direito Público, $\mathrm{n}^{\circ}$ 19, ano V, janeiro-março de 1972, pp. 51-59.

MOREIRA, Mauricio Mesquita. Câmbio e Crescimento na América Latina, in Nação, Câmbio e Desenvolvimento, organização BRESSER-PEREIRA, Luiz Carlos, Rio de Janeiro: Editora FGV, 2008.

MOSQUERA, Roberto Quiroga. Direito Monetário e Tributação da Moeda. São Paulo: Dialética, 2006.

NUSDEO, Fábio. Curso de Economia. Introdução ao Direito Econômico, 3 a edição revista e atualizada, São Paulo: Editora Revista dos Tribunais, 2001.

Desenvolvimento Econômico - Um retrospecto e algumas perspectivas, in Regulação e Desenvolvimento, coordenação SALOMÃO FILHO, Calixto, São Paulo: Malheiros, 2002, pp. 11-24.

NUSSBAUM, Arthur. Teoria Jurídica del Dinero. Madri: Librería General de Victoriano Suárez, 1999.

PEDREIRA, José Luiz Bulhões. Finanças e demonstrações financeiras da companhia: conceitos e fundamentos, $2^{\mathrm{a}}$ edição, Rio de Janeiro: Forense, 1989.

PIETRO, Maria Sylvia Zanella di. Discricionariedade Técnica e Discricionariedade Administrativa, in Revista Eletrônica de Direito Administrativo Econômico (REDAE), Salvador: Instituto Brasileiro de Direito Público, $n^{\circ}$ 9, fevereiro/março/abril, 2007. Texto disponível em www.direitodoestado.com.br/redae.asp. Acessado em 21 de janeiro de 2009. 
PIMENTEL, Manoel Pedro. Crimes contra o sistema financeiro nacional: comentários à Lei 7.492, de 16.6.86, São Paulo: Editora Revista dos Tribunais, 1987.

PINTO, Jayme Bastian. Alguns Aspectos do Controle de Câmbio, Revista de Direito Administrativo, volume 150, outubro-dezembro de 1982, pp. 227-245.

POLANYI, Karl. A Grande Transformação. As Origens da Nossa Época, $2^{\mathrm{a}}$ edição, Rio de Janeiro: Elsevier, 2000.

PROCTOR, Charles. Mann on the Legal Aspect of Money, $6^{\mathrm{a}}$ edição, Oxford: Oxford University Press, 2005.

SALOMÃO FILHO, Calixto. Regulação e Desenvolvimento, in Regulação $e$ Desenvolvimento, coordenação SALOMÃO FILHO, Calixto, São Paulo: Malheiros, 2002, pp. 29-63.

SARETTA, Fausto. A Política Econômica no Período 1954/1955: algumas notas. Texto disponível em http://www.abphe.org.br/congresso2003/Textos/Abphe_2003_61.pdf. Acessado em 25 de dezembro de 2008.

SCHUMPETER, Joseph A. Teoria do Desenvolvimento Econômico. Rio de Janeiro: Editora Fundo de Cultura, 1961.

SICSÚ, João. Mais um passo liberalizante: comentários sobre as novas normas cambiais. Disponível em www.ie.ufrj.br/moeda/pdfs/novas_normas_cambiais.pdf. Acessado em 28 de julho de 2008.

SILVA, José Afonso da. Curso de Direito Constitucional Positivo, 23 ${ }^{\mathrm{a}}$ edição, São Paulo: Malheiros Editores, 2004.

SIMONSEN, Mario Henrique, CYSNE, Rubens Penha. Macroeconomia, $2^{\mathrm{a}}$ edição, São Paulo: Atlas, 1995. 
SOUZA, Renato A. Gomes de. Câmbio. Dos Controles Rígidos à Liberalização, Rio de Janeiro: Renovar, 2007.

SOUZA, Washington Peluso Albino de. Teoria da Constituição Econômica, Belo Horizonte: Del Rey, 2002.

TORRES, Ricardo Lobo. O Orçamento na Constituição, Rio de Janeiro: Renovar, 1995.

VENÂNCIO FILHO, Alberto. A Intervenção do Estado no Domínio Econômico: o direito público econômico no Brasil, Rio de Janeiro: Renovar, 1998.

VERÇOSA, Haroldo Malheiros Duclerc. Aspectos Jurídicos do Câmbio. Dissertação de Mestrado apresentada na Faculdade de Direito da Universidade de São Paulo, 1978.

Notas sobre o Sistema de Controle de Câmbio no Brasil, Revista de Direito Mercantil, Industrial, Econômico e Financeiro, nº 78, abril/junho de 1990, pp. 24-45.

O Contrato de Câmbio, Revista de Direito Mercantil, Industrial, Econômico e Financeiro, nº 42, abril/junho de 1981, p. 22.

WILLIAMSON, John. A Short History of the Washington Consensus. Trabalho apresentado na conferência "From the Washington Consensus towards a new Global Governance", nos dias 24 e 25 de setembro de 2004, em Barcelona. Texto disponível em http://www.iie.com/publications/papers/williamson0904-2.pdf. Acessado em 20 de dezembro de 2008.

YAZBEK, Otavio. Regulação do Mercado Financeiro e de Capitais, Rio de Janeiro: Elsevier, 2007.

ZINI JÚNIOR, Álvaro Antônio. Taxa de Câmbio e Política Cambial no Brasil, $2^{\mathrm{a}}$ edição, São Paulo: Editora da Universidade de São Paulo, 1995. 


\section{b) Obras consultadas de autores institucionais}

BANCO CENTRAL DO BRASIL. O Regime Cambial Brasileiro - Evolução Recente e Perspectivas, novembro de 1993.

Quadro Comparativo 1 - Unificação dos Mercados de Câmbio Resolução 3.265, de 4 de março de 2005 (reunião do Mercado de Câmbio de Taxas Livres e do Mercado de Câmbio de Taxas Flutuantes e instituição de um único mercado de câmbio). Texto disponível em $\quad$ www.bcb.gov.br/rex/LegCE/Port/Ftp /comparativo_marco_2005.pdf. Acessado em 18 de dezembro de 2008.

Medidas de Simplificação na Área de Câmbio, agosto de 2008.

Texto disponível em www.bcb.gov.br. Acessado em 13 de outubro de 2008.

CONSELHO DE RECURSOS DO SISTEMA FINANCEIRO NACIONAL. Relatório de Atividades. $\quad$ Ano-base: $2003 . \quad$ Texto disponível em http://www.bcb.gov.br/crsfn/relatorio\%202003\%20CRSFN.pdf. Acessado em 21 de janeiro de 2009.

FUNDO MONETÁRIO INTERNACIONAL / INTERNATIONAL MONETARY FUND. Classification of Exchange Rate Arrangements and Monetary Policy Frameworks, 30 de junho de 2004. Texto disponível em http://www.imf.org/external/np/mfd/er/2004/eng/0604.htm. Acessado em 16 de dezembro de 2008.

SECRETARIA DE ASSUNTOS INTERNACIONAIS DO MINISTÉRIO DA FAZENDA. Mecanismos de Financiamento Privado a Exportação. Texto disponível em www.fazenda.gov.br/sain/temas/exportacoes.asp. Acessado em 23 de novembro de 2008.

SECRETARIA DE COMÉRCIO EXTERIOR DO MINISTÉRIO DO DESENVOLVIMENTO, INDÚSTRIA E COMÉRCIO EXTERIOR. Balança Comercial Brasileira - Dados Consolidados Janeiro-Junho de 2008. Texto disponível em http://www.desenvolvimento.gov.br/arquivos/dwnl_1217525563.pdf. Acessado em 14 de dezembro de 2008. 